\title{
Archaeological Investigations at the Levi Jordan Plantation State Historic Site, Brazoria County, Texas
}

Carole Leezer

Center for Archaeological Studies

Follow this and additional works at: https://scholarworks.sfasu.edu/ita

Part of the American Material Culture Commons, Archaeological Anthropology Commons, Environmental Studies Commons, Other American Studies Commons, Other Arts and Humanities Commons, Other History of Art, Architecture, and Archaeology Commons, and the United States History Commons

Tell us how this article helped you.

This Article is brought to you for free and open access by the Center for Regional Heritage Research at SFA ScholarWorks. It has been accepted for inclusion in Index of Texas Archaeology: Open Access Gray Literature from the Lone Star State by an authorized editor of SFA ScholarWorks. For more information, please contact cdsscholarworks@sfasu.edu. 


\section{Archaeological Investigations at the Levi Jordan Plantation State Historic Site, Brazoria County, Texas}

\section{Creative Commons License}

\section{(c) (1) (8)}

This work is licensed under a Creative Commons Attribution-NonCommercial 4.0 International License 

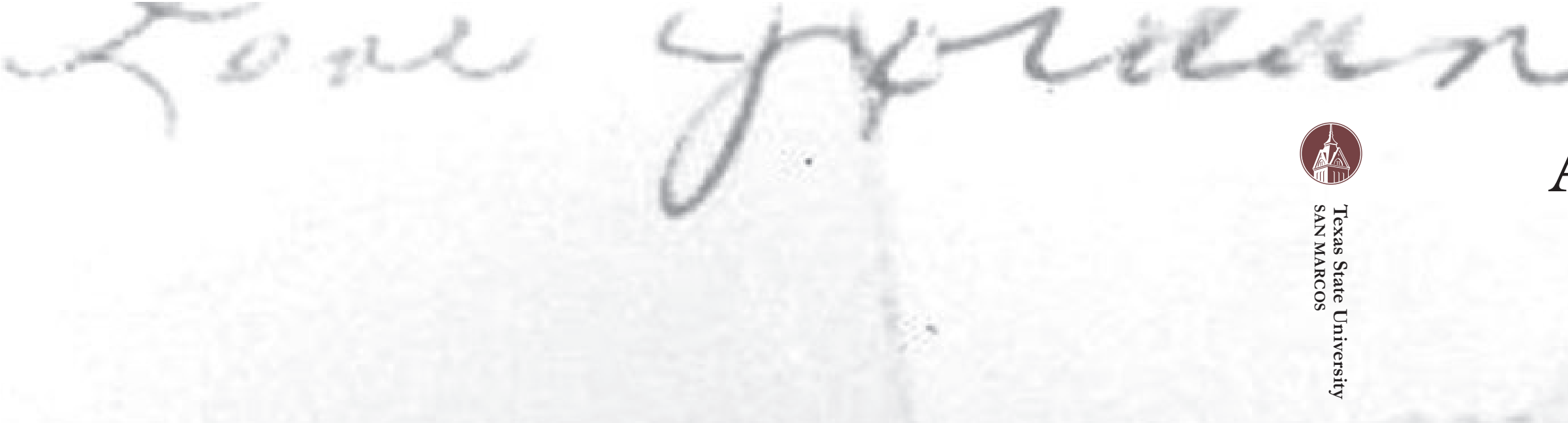

Archaeological Investigations at the

\section{Levi Jordan Plantation} State Historic Site, Brazoria County,

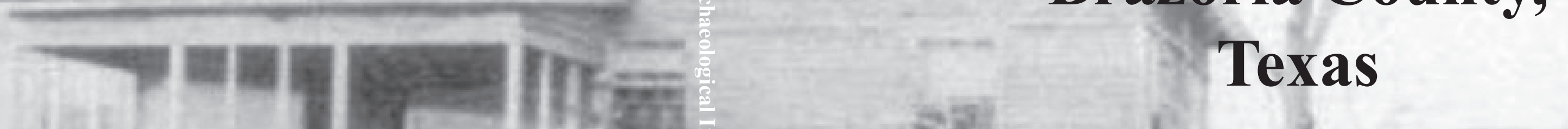




\section{Archaeological Investigations at the Levi Jordan Plantation State Historic Site, Brazoria County, Texas}


The following information is provided in accordance with the General Rules of Practice and Procedures, Title 13, Chapter 26, Texas Administrative Code:

1. Type of investigation: Intensive archaeological survey with excavation of shovel tests and 3x3-ft units.

2. Project name: Archaeological Investigations at the Levi Jordan Plantation State Historic Site, Brazoria County, Texas

3. County: Brazoria

4. Principal Investigators: Carole Leezer and C. Britt Bousman

5. Name and location of sponsoring agency: Texas Parks and Wildlife Department, Austin, Texas

6. Texas Antiquities Permit No. 3800

7. Published by the Center for Archaeological Studies, Texas State University-San Marcos, 601 University Drive, San Marcos, Texas, 78666-4616 (2006)

Texas State University-San Marcos is a member of the Texas State University System Copyright (C) 2006 by the Center for Archaeological Studies at Texas State University-San Marcos

All rights reserved.

No part of this book may be reproduced or utilized in any form or by any means, electronic or mechanical, including photocopying, recording,

or by any information storage and retrieval system without permission in writing.

For further information on this and other publications by the Center for Archaeological Studies, please contact:

Center for Archaeological Studies Texas State University-San Marcos 601 University Drive San Marcos, TX 78666-4616 www.txstate.edu/anthropology/cas/

Editor: Maggie Moore

Cover Photograph: The Levi Jordan Plantation house (date unknown), Brazoria County Historical Museum Collection <http://www.bchm.org/photos/p1144.html>.

Printed in the United States 


\section{Abstract}

At the request of the Texas Parks and Wildlife Department (TPWD), the Center for Archaeological Studies (CAS) at Texas State University-San Marcos conducted limited test excavations at the Levi Jordan Plantation State Historic Site (41BO165). The Levi Jordan Plantation was established by Levi Jordan in 1848. At its height, this antebellum sugar and cotton plantation sat on more than 2,000 acres of rich river bottomlands in the Gulf Coastal Plains of Brazoria County, Texas. Limited test excavations focused on areas around and within the main house, in addition to areas to be developed for interpretation and public access to the site. Survey and excavations were conducted during June and July of 2005 under Texas Antiquities Permit No. 3800. Limited excavations at the main house support an occupation that extends from the antebellum period through the end of the twentieth century. Numerous features uncovered during excavations provide valuable information concerning the original construction and additions to the main house. Artifacts collected during the project were processed in accordance with TPWD Archaeology Lab Manual and curated at TPWD. Archaeological data from the current archaeological investigation addressed questions on the historical development of the main house and site. This data will be utilized by TPWD for long-term stewardship, interpretation, and management of these resources. 


\section{Table of Contents}

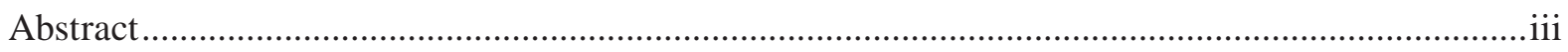

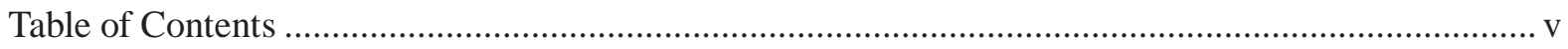

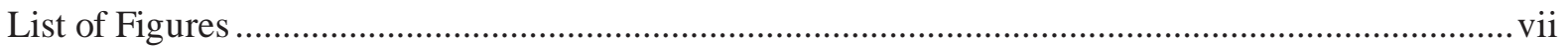

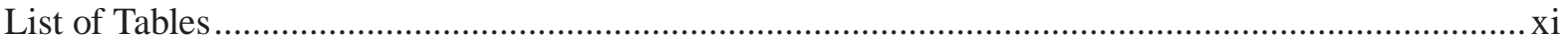

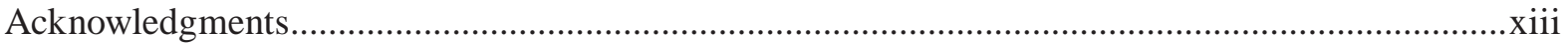

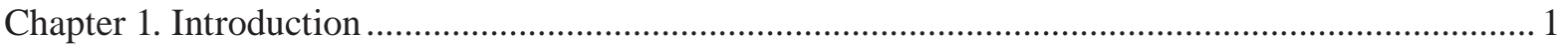

Chapter 2. Environmental, Cultural, and Archaeological Background ............................................. 5

Chapter 3. The Development of a Socioeconomic Plantation System in Brazoria County.................. 13

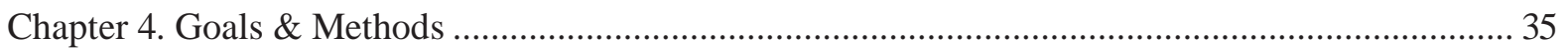

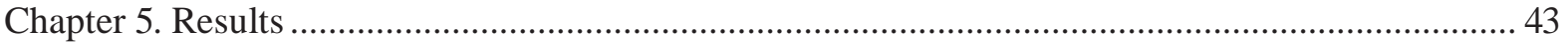

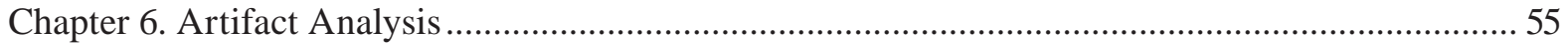

Chapter 7. Interpretations, Conclusions, and Recommendations ..................................................... 77

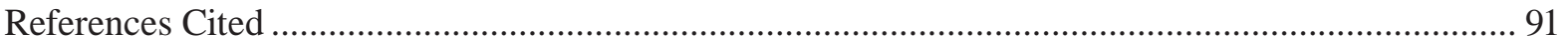

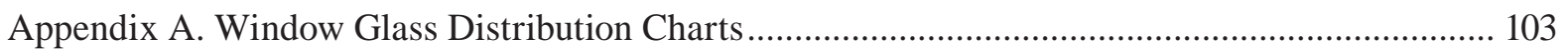

Appendix B. Levi Jordan Plantation State Historic Site Artifact Classification System ....................115

Appendix C. Levi Jordan Plantation State Historic Site Artifact Catalogue ..................................... 123 


\section{List OF Figures}

1-1. Map of the Sweeny area showing the location of the project ................................................. 1

1-2. Main house at the Levi Jordan Plantation, facing northeast...................................................... 2

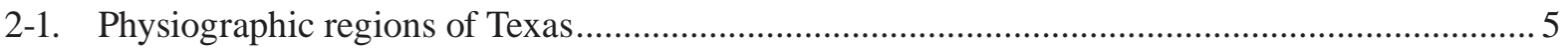

2-2. Plantations in the vicinity of the Levi Jordan Plantation..........................................................11

3-1. Line graph showing the rise and decline of slave numbers in Brazoria County, Texas ............. 13

3-2. George Shackelford sketch of the Bell Plantation (date unknown) ......................................... 17

3-3. Don Hutson painting of the Abner Jackson Plantation main house in Lake Jackson................. 17

3-4. 1898 photograph of the slave quarters at the Durazno Plantation near Jones Creek ................. 17

3-5. Photograph of the Varner-Hogg Plantation, West Columbia (date unknown) ........................... 18

3-6. Photograph of a cotton gin in Sweeny (date unknown) .......................................................... 18

3-7. Photograph of the sugar mill at the Waldeck Plantation (date unknown)................................ 18

3-8. Levi Jordan Plantation historical marker plaque ..................................................................... 19

3-9. Alan A. Platter's sketch of the Levi Jordan Plantation ....................................................... 19

3-10. Sketch map from the original National Register of Historic Places nomination....................... 20

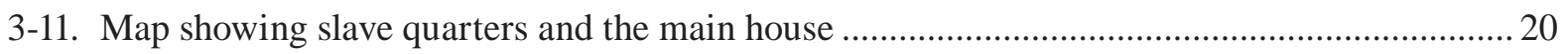

3-12. Map showing the location of slave quarters, main house, sugar mill, and the Jaden

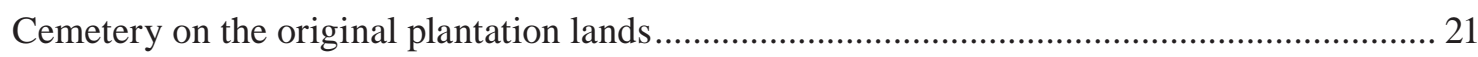

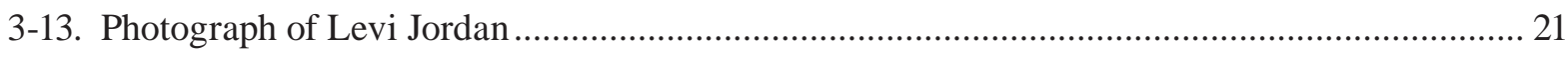

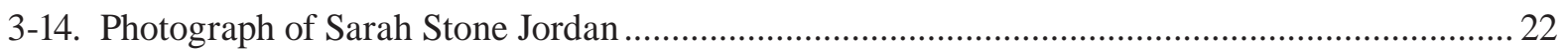

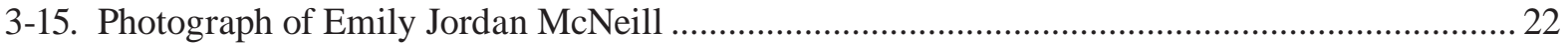

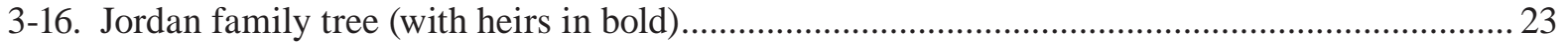

3-17. Graph of Levi Jordan’s assets, 1848-1873 ............................................................................ 24

3-18. Graph of cotton production at the Levi Jordan Plantation, 1850-1870 ................................... 25

3-19. Graph of sugar and molasses production at the Levi Jordan Plantation, 1853-1870................. 25

3-20. Graph of miscellaneous crops production at the Levi Jordan Plantation, 1850-1870 ............... 26 


\section{List OF Figures (CONTINUed)}

3-21. Line graph showing the rise and decline of slave numbers at the Jordan Plantation ................ 27

3-22. Photograph of the Levi Jordan Plantation house showing the front porch ................................ 28

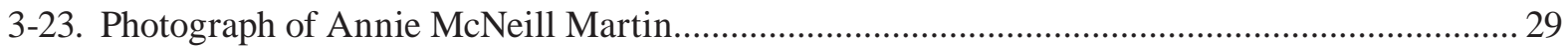

3-24. Excerpt from Levi Jordan’s will banning Annie Martin and her husband from the

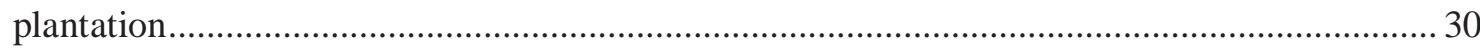

3-25. The Martin brothers: Calvin, Royal Furniss, McWillie, and Charles..................................... 31

4-1. Map of the plantation house showing zones and placement of excavation units....................... 36

4-2. Location of Zone $\mathrm{Z}$ in relation to the main plantation house.................................................... 37

4-3. Map of Zone Z showing locations of shovel tests and Unit Z1 .............................................. 41

5-1. Illustration of the surface of Unit A1 showing numbered bricks ........................................... 43

5-2. Illustration of Unit A1 level 2 (4-8 inbd) showing Feature 1............................................... 44

5-3. Photograph of Unit A2 level 1 (0-4 inbd) showing numbered bricks....................................... 44

5-4. Photograph of Unit A5 level 1 (0-4 inbd) showing brick caliché terrace ................................ 46

5-5. Photograph of Unit B1 level 1 (0-4 inbd) showing Feature 2 ................................................46

5-6. Photograph of Unit B1 level 4 (12-16 inbd) showing Feature 2 and brick step-outs ................ 47

5-7. Illustration of Unit B1 level 4 (12-16 inbd) showing Feature 2 and the exploratory

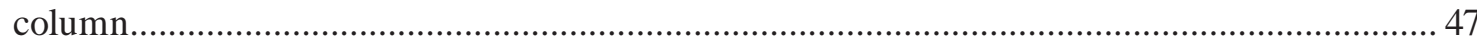

5-8. Illustration of Unit B2 level 4 (12-16 inbd) showing the exploratory column and the

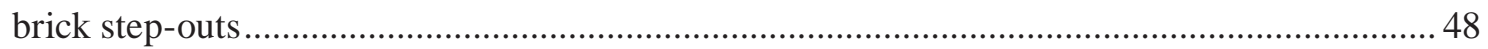

5-9. Photograph of Unit C1 level 3 (8-12 inbd) showing Feature 3............................................. 48

5-10. Illustration of Unit C2 level 4 (12-16 inbd) showing Feature 4 and exploratory column

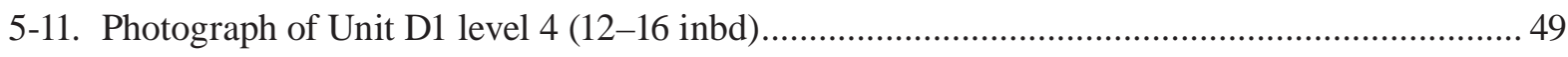

5-12. Photograph of Unit D2 level 2 (4-8 inbd) showing Feature 5 and numbered bricks ................. 50

5-13. Photograph of Unit D2 level 4 (12-16 inbd) showing Feature 5 pedestaled with

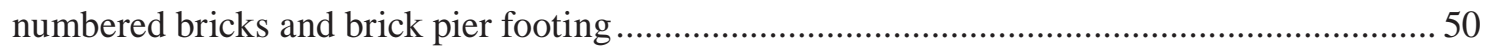

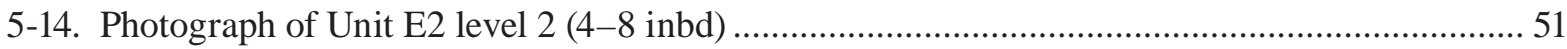




\section{List OF Figures (CONTINUed)}

5-15. Illustration of unit E2 level 4 (12-16 inbd) showing Feature 6............................................. 51

5-16. Photograph of eroded pipe in southern wall profile of Unit E2 at 10-12 inbd ......................... 52

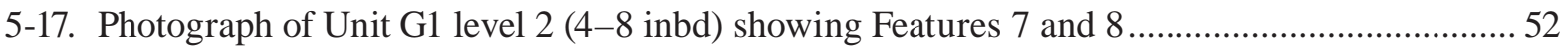

5-18. Photograph of Unit G1 level 4 (12-16 inbd) showing Feature 7 pedestaled............................... 53

5-19. Photograph of Unit G1 level 5 (16-20 inbd) showing brick step-outs ....................................... 53

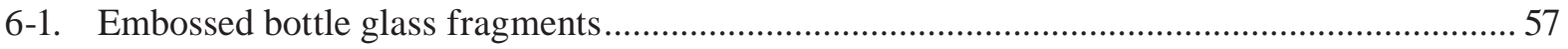

6-2. Examples of tableware glass and a mason jar lid liner ........................................................ 59

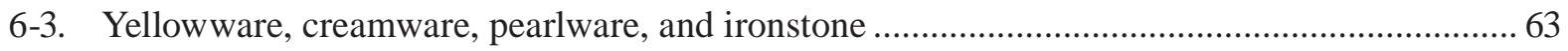

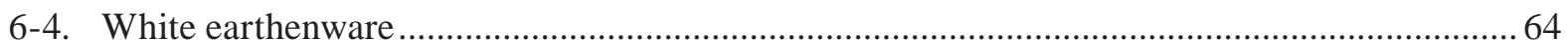

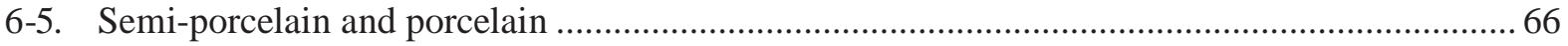

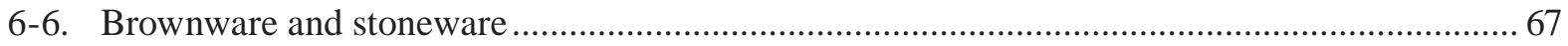

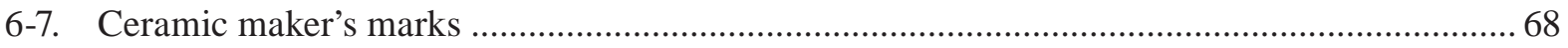

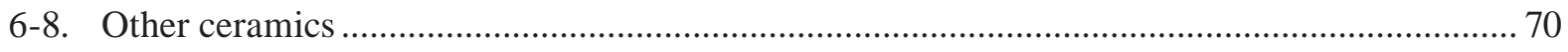

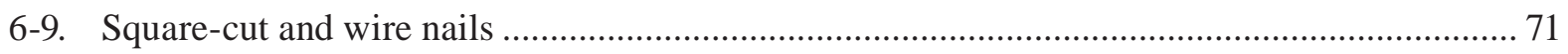

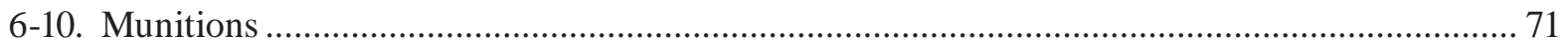

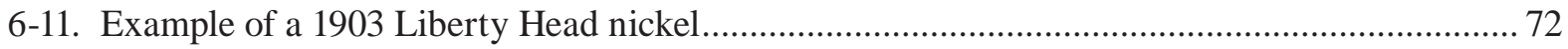

6-12. Example of a 1925 Buffalo/Indian Head nickel .......................................................................... 72

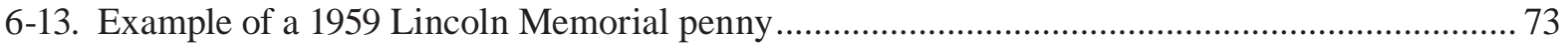

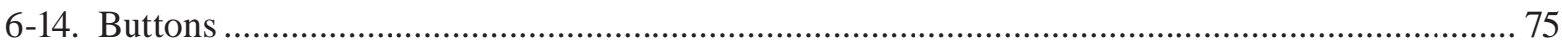

7-1. Illustration of Zone A indicating locations of units, Feature 1, and possible extent of original brick walkways and terraces .............................................................................. 78

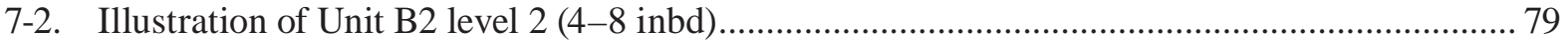

7-3. Illustration of Zone B showing brick step-outs and north wall of the original wing ................. 80

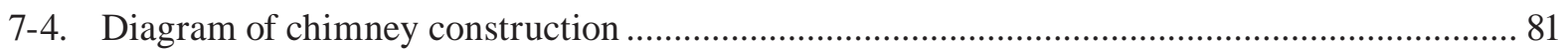

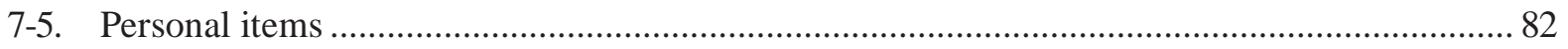




\section{List OF Figures (CONTINUed)}

7-6. Illustration of Zone C indicating the locations of units, Features 3 and 4, and the similar construction of the chimney

7-7. Illustration of Zones B and E indicating the locations of Units B1, B2, E1, E2, and Features 2 and 6

A-1. Bar graph showing temporal window glass distribution at the Levi Jordan State Historic Site (41BO165) and associated hurricane event dates. 101

A-2. Bar graph showing the temporal window glass distribution for Zone A ................................ 102

A-3. Bar graph showing the temporal window glass distribution for Zone B................................ 102

A-4. Bar graph showing the temporal window glass distribution for Zone C.................................. 103

A-5. Bar graph showing the temporal window glass distribution for Zone D ............................... 103

A-6. Bar graph showing the temporal window glass distribution for Zone E ................................ 104

A-7. Bar graph showing the temporal window glass distribution for Zone G ............................... 104

A-8. Bar graph showing the temporal window glass distribution for Unit A1 ............................... 105

A-9. Bar graph showing the temporal window glass distribution for Unit A2 ................................ 105

A-10. Bar graph showing the temporal window glass distribution for Unit A3............................... 106

A-11. Bar graph showing the temporal window glass distribution for Unit A4 ................................ 106

A-12. Bar graph showing the temporal window glass distribution for Unit A5 ............................... 107

A-13. Bar graph showing the temporal window glass distribution for Unit B1 .............................. 108

A-14. Bar graph showing the temporal window glass distribution for Unit B2 ............................... 108

A-15. Bar graph showing the temporal window glass distribution for Unit C1 .............................. 109

A-16. Bar graph showing the temporal window glass distribution for Unit C2 ................................ 109

A-17. Bar graph showing the temporal window glass distribution for Unit D1 ..............................110

A-18. Bar graph showing the temporal window glass distribution for Unit D2...............................110

A-19. Bar graph showing the temporal window glass distribution for Unit E1 ................................111

A-20. Bar graph showing the temporal window glass distribution for Unit E2 .................................111

A-21. Bar graph showing the temporal window glass distribution for Unit G1 ................................112 


\section{List OF TABLES}

2-1. Previously recorded historic sites in Brazoria County, Texas .............................................. 10

3-1. Timeline of ownership of the Levi Jordan Plantation House...................................................... 32

5-1. Summary of artifacts recovered from excavations at the Levi Jordan Plantation..................... 45

6-1. Compounds added to glass to produce colors.......................................................................... 56

6-2. Identified ceramic maker’s marks from the Levi Jordan Plantation.......................................... 69

6-3. Unidentified ceramic maker’s marks from the Levi Jordan Plantation ................................... 69

6-4. Identified munitions headstamps from the Levi Jordan Plantation ........................................... 72

7-1. Counts and percentages of ceramics recovered from the Levi Jordan Plantation..................... 88 


\section{AcKnowledgements}

The author has many colleagues and professional staff to thank for the content and quality of this publication. All those involved in the process took a personal interest in telling the story of the Levi Jordan Plantation. I would first like to extend my deep-felt gratitude to Michael Strutt, Laura David and Art Black (retired) of the Texas Parks and Wildlife Department for affording me the opportunity to conduct archaeological research on the Levi Jordan Plantation. Dr. Britt Bousman, David Nickels, and Eric Oksanen provided professional advice and guidance throughout the project. I am also grateful to my field crew, David Peyton, Beth Sain and Matthew Stotts, who endured sweltering heat and humidity in addition to dense patches of poison ivy. Art Black's assistance during excavations within and next to the main house was beneficial and greatly appreciated.

The processing and analysis of artifacts was an important component of this research. I would like to extend a deep-felt appreciation to Maggie Moore, who oversaw this process. She was aided by several individuals: Ashley Huffman, Holly Meier, Denise Perez, David Peyton, Beth Sain, Joseph Thompson, Nicole Vaughn, and Emory Worrell. I would like to extend a special thanks to Kristi Miller Ulrich for her advice on ceramic analysis. Thanks to Jessica Hurley who edited the first draft of this report. Matt Melancon, who I am grateful to, produced the many graphic illustrations in this report. Finally, this report would not have been possible without the editorial skills of Maggie Moore, who assembled and edited the final report. 


\section{Chapter 1}

\section{INTRODUCTION}

In June of 2005, the Texas Parks and Wildlife Department (TPWD) contracted the Center for Archaeological Studies (CAS) at Texas State University-San Marcos to conduct limited archaeological investigations of the Levi Jordan Plantation State Historic Site (41BO165). This nineteenth-century sugar cane and cotton plantation once encompassed more than 2000 acres, and produced 77 bales of cotton and 193 hogsheads of sugar in 1860. It is located in Brazoria County, Texas, approximately 60 miles south of Houston, 15 miles inland from the Gulf of Mexico (Brown 1994:97), and four miles

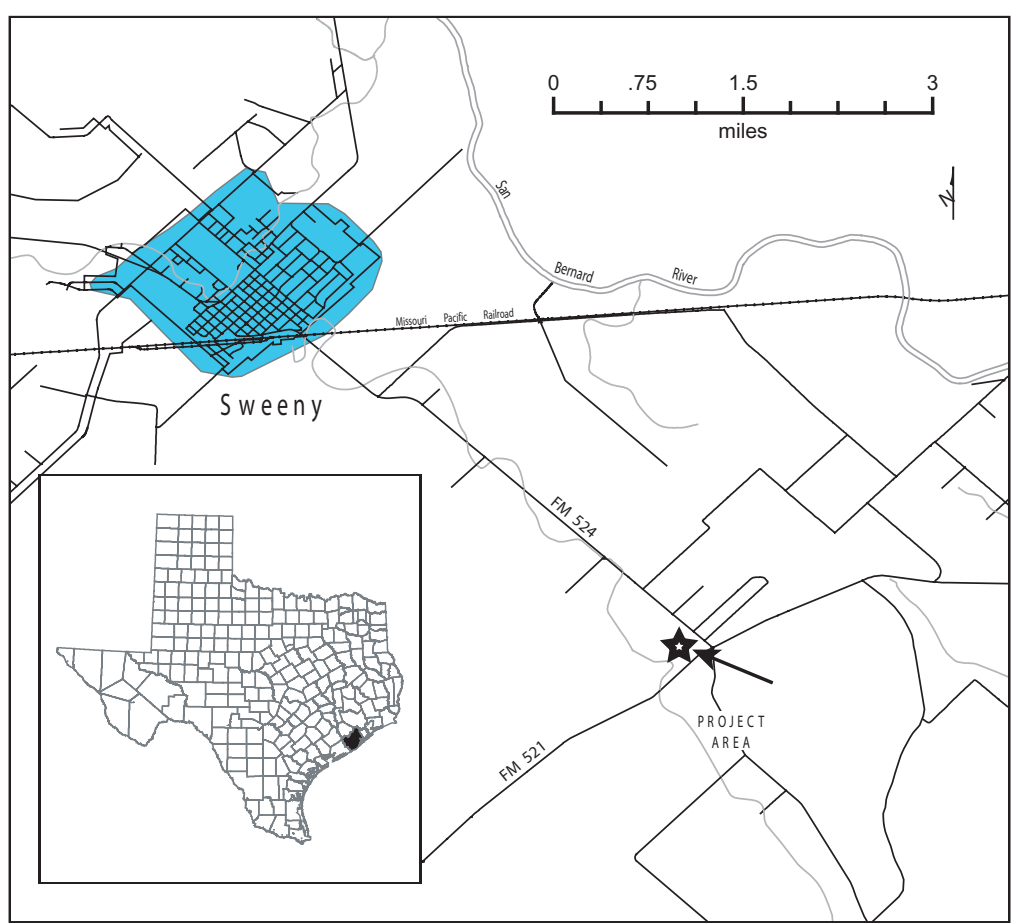

Figure 1-1. Map of the Sweeny area showing the location of the project; inset of Brazoria County, Texas. southeast of the town of Sweeny (Figure 1-1). In 2002 and 2003, TPWD purchased the present 92-acre property to develop it for historical interpretation and public access.

The plantation house is the only original building still standing and intact on the Levi Jordan Plantation (Figure 1-2). CAS conducted limited test excavations around the main house and surrounding areas with two main goals: to document the original configuration of the house and its subsequent changes; and to provide archaeological clearance prior to the development of parking and visitor center areas.

\section{Project Background}

The Levi Jordan Plantation is a historic sugar cane and cotton plantation established in 1848 by Levi Jordan, his wife Sarah, their daughter Emily, her husband James Campbell McNeill, and enslaved African Americans (Brown 1994:97). Historical documents indicate that Levi Jordan emigrated from Arkansas with 12 slaves in 1848 and acquired 2,221 acres of land on the San Bernard River. This acreage was purchased from Samuel M. Williams and was originally the 


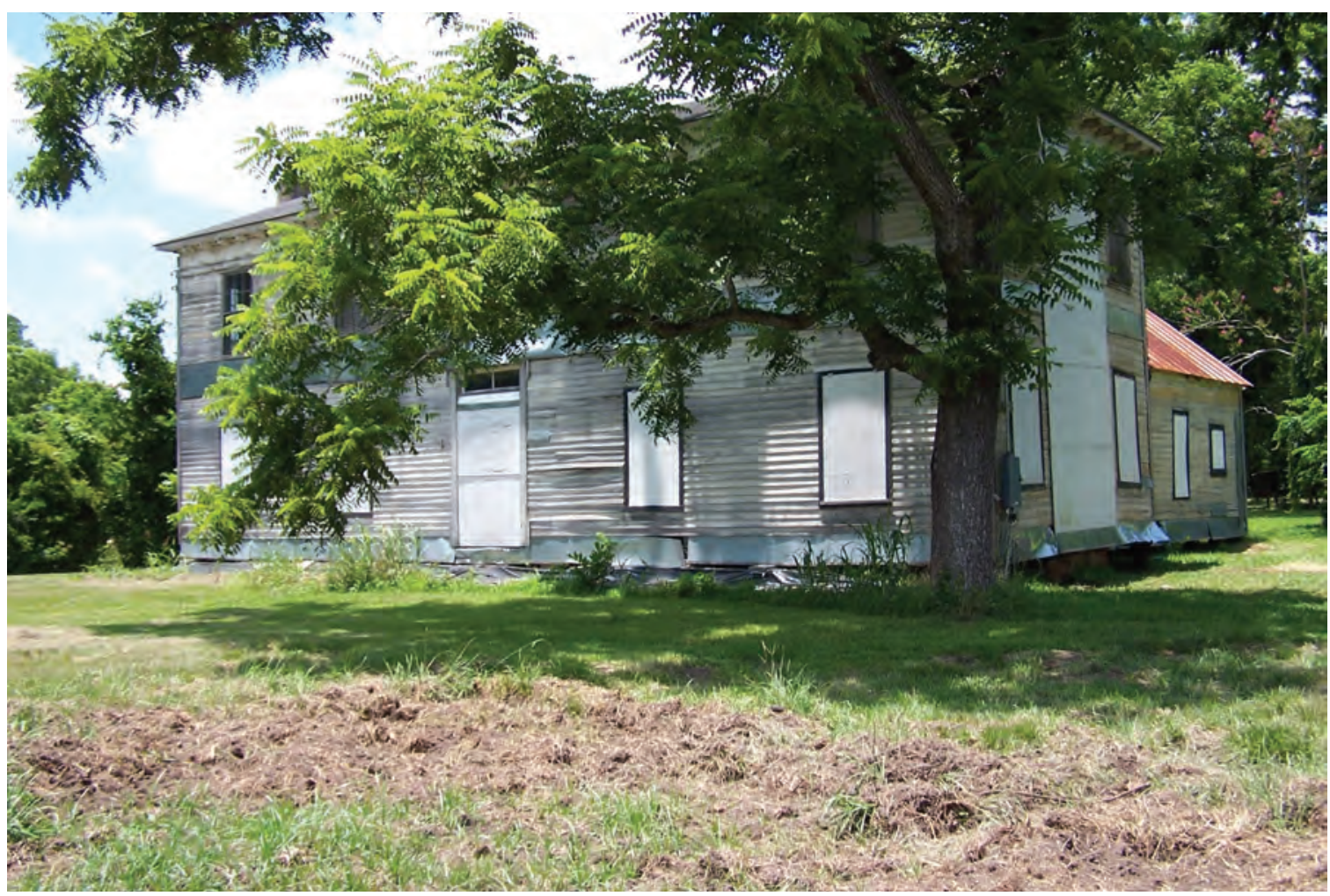

Figure 1-2. Main house at the Levi Jordan Plantation, facing northeast (photograph taken June 2005).

western half of Williams's land grant (Freeman 2003:107). The Levi Jordan Plantation was one of several plantations established along the rich bottomlands of Brazoria County.

Following the death of Levi Jordan in 1873, half of the plantation property was left to his grandson, William McNeill. Sarah, Levi Jordan's widow, sold the remaining half to William in 1877, giving him ownership of the full 2,221 acres. William died in 1878 with no heirs, and the property reverted back to the surviving members of the family. In 1981, Dorothy Cotton and other Levi Jordan descendants inherited the seventy acres of the original plantation that contain the original plantation house, which remained occupied through the 1990s (Freeman 2003:134-135). TPWD acquired the property from these descendents in March of 2002, and bought an additional 22 acres of the original plantation grounds in June of 2003 (TPWD 2003:3).
Dr. Kenneth L. Brown and his students from the University of Houston conducted research at the Levi Jordan Plantation between 1986 and 2002. This research has focused primarily on the slave and tenant quarters, which were occupied by slaves who remained as sharecroppers and tenant farmers until 1892. Brown's project also completed a non-intrusive surface survey of the Jaden Cemetery, which was used by the plantation's African American residents. From this survey it was determined that the cemetery was in use from the period of slavery until modern times. These investigations provide valuable clues to the cultural dynamic of an African American community established in 1848 (Brown 1994:97).

Although Dr. Brown and his students also carried out limited excavations around the main plantation house and its yard, no extensive work has been done on the house. Historical records indicate that the house has undergone 
several renovation phases, but these records are unclear on the exact nature of these construction phases. Archaeological investigations by CAS documented these changes and postulated reasons behind them.

The Levi Jordan Plantation provides an excellent opportunity to study the history of Texas plantations through the documentation of their cultural and natural landscapes. Large-scale sugar and cotton plantations were quite common in Brazoria County during the nineteenth century. Archaeological research on plantations such as the VarnerHogg/Patton Plantation (Earls and Tomka 1994) and the Lake Jackson Plantation (Few 1999) has contributed beneficial information to the economic roles and social impact of plantations in antebellum Texas. The Levi Jordan Plantation provides an important venue for the continued study of the socioeconomic environment of antebellum Texas.

\section{Project Overview}

Archaeological evaluation consisted of the documentation and excavation of features inside and near the main house, and survey and shovel test excavation in an area selected for the development of a visitor center and maintenance yard. Fourteen units measuring $3 \times 3$ feet (ft) were excavated by hand underneath or next to the house, which was the primary area of study identified by TPWD. The secondary area of study, the visitor center and maintenance area, was investigated through pedestrian survey and the placement of 36 shovel tests and one $3 \times 3-\mathrm{ft}$ unit. Artifacts recovered during investigations were processed in accordance with guidelines established in the Archeology Lab Manual (TPWD 1995). All artifacts recovered during the research were subjected to description and/or analysis, with the results presented in this report.

\section{Report Layout}

This report is composed of seven chapters and three appendices. Following this introductory chapter, Chapter 2 presents a review of the archaeological background of the project area including an assessment of both prehistoric and historic sites recorded near the Levi Jordan Plantation. A summary report of the development of plantations in Brazoria County, with a brief history of the Levi Jordan Plantation, is presented in Chapter 3. Chapter 4 introduces the methods and research perspectives that guided the CAS investigations at this site. The results of these investigations are detailed in Chapter 5, and Chapter 6 contains analysis and discussion of the artifacts. Chapter 7 concludes the report with a summary of the project findings and makes recommendations for further work and testing of the site. Appendix A contains distribution charts for window glass, Appendix B lists the artifact catalogue system used, and Appendix C contains the laboratory catalogue of all artifacts recovered from excavations by CAS. 


\section{Chapter 2}

\section{Environmental, Cultural, And Archaeological Background}

Brazoria County is situated in a region of Texas that has long attracted people due to its plant and animal resources. From the Paleoindian through historic times, various peoples and cultures have taken advantage of these resources in addition to its rich soils and temperate climate. Evidence of occupation is seen through an examination of the archaeological record of the region.

\section{Environment}

The Levi Jordan Plantation is located along the eastern portion of the Gulf Coast Prairies and Marshes Region of Southeast Texas (Figure 2-1). This region is composed of belt-like strips of alluvial deltaic soil that run parallel to the Gulf of Mexico (Story et al. 1990:5). During the Middle to Late Pleistocene, a series of glacial and interglacial intervals deposited these alluvial deltaic soils, known as the Beaumont Formation.

Soils of the study area primarily consist of Asa silty clay loam, Norwood silt loam, and Pledger clay (Crenwelge et al. 1981). The Pledger clay soils are located in the northern section of the current plantation site, while the main plantation house is built on Asa silty clay loam soils. The slough area to the west of the main house is characterized by Norwood silt loam in one to five percent slopes (TPWD 2003:17).

The current climate of this area is predominately marine, with winds prevailing from the south and southeast (Crenwelge et al. 1981). Winds from the Gulf of Mexico moderate temperatures, which range in mean daily temperatures from $81^{\circ} \mathrm{F}\left(27^{\circ} \mathrm{C}\right)$ in the summer to $55^{\circ} \mathrm{F}\left(13^{\circ} \mathrm{C}\right)$ during the winter (Crenwelge et al. 1981). Precipitation averages 52 inches (132 $\mathrm{cm}$ ) per year, and is scattered throughout the year

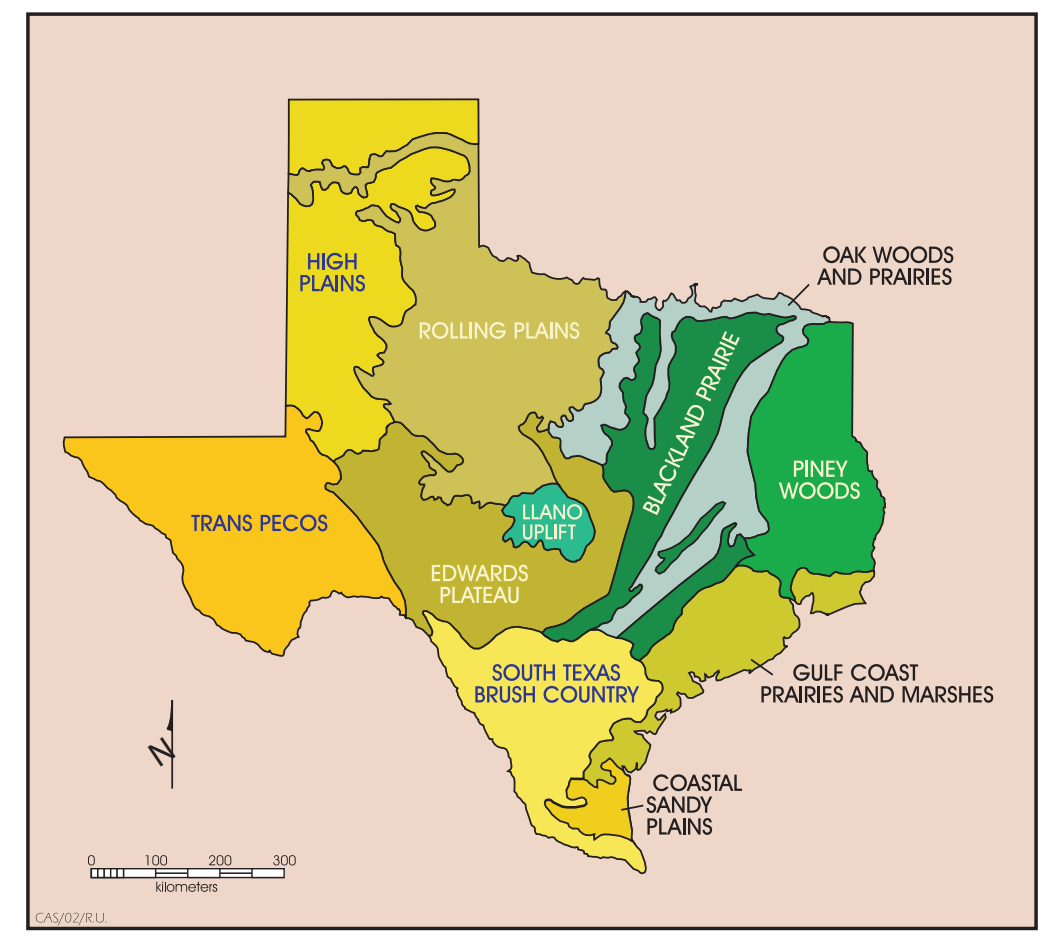

Figure 2-1. Physiographic regions of Texas (TPWD 2005a). 
with a mix of thunderstorms, tropical storms, heavy fog, and rare snowfalls (Crenwelge et al. 1981). The average relative humidity is 60 percent in the mid-afternoon and 90 percent at dawn (Crenwelge et al. 1981).

Twentieth-century urbanization and agriculture has altered the flora of this region from its original post oak savannah and tall grass prairie to thickets of trees and shrubs (Mattiza 1993). Native grasses of this region include little bluestem (Schizachyrium scoparium), silver bluestem (Bothricohloa laguroides), and brownseed paspalum (Paspalum plicatulum). The dominant tree species in this region is the post oak (Quercus stellata), with other species found such as blackjack oak (Quercus marilandica), water oak (Quercus nigra), winged elm (Ulmus alata), hackberry (Celtis occidentalis), and yaupon (Ilex vomitoria). Land clearing for agricultural purposes has resulted in a higher density of smaller trees and a thick undergrowth of vegetation, especially yaupon. Most bottomlands in the region have been cleared of their large hardwoods, resulting in thick understories. According to early written accounts, white-tailed deer (Odocoileus virginianus), wild turkey (Meleagris gallopavo), bison (Bison bison), black bear (Ursus americanus), squirrel (Sciurus carolinensis), mountain lion (Felis concolor), and red wolf (Canis rufus) were once common in this region (TPWD 2005b).

\section{Cultural Background}

The Gulf Coast Prairies and Marshes Region has been traditionally described as a cultural buffer zone. Patterson (1995:243) depicts the archaeological record of this area as a boundary region between Southern Plains and Southeast Woodland cultures. As such, the archaeological record of this region contains a mixture of local innovation and diffused technology.
The prehistoric cultural sequences of coastal southeastern Texas are presented in length by Story et al. (1990), Patterson (1995), Ricklis (1995), and Fields (1995). A brief outline of these cultural sequences follows.

\section{Paleoindian}

The Paleoindian period, dated between 10,000 and 5,000 BC (Patterson 1995: 243), is identified by a general hunter-gatherer subsistence strategy. This era is poorly represented in the archaeological record of the region (Aten 1983), as no sites for this period have been verified. However, Aten (1983) states that isolated artifacts dating to this period, including Clovis, Angostura, Scottsbluff, Meserve, Plainview, and Golondrina point types, have been identified within the project locality.

\section{Archaic}

A shift from a general hunter-gatherer to a broad-based subsistence strategy characterizes the Archaic period, which dates between 5,000 BC and AD 100 (Patterson 1995:243). It is also during this period that rising sea levels, climatic fluctuations and shifts in raw material usage and technology occur. Cemeteries, stone-lined hearths, baking pits, milling implements, and pecked and polished stone ornaments and implements appear at this time (Story et al. 1990). The few Archaic sites located within the Gulf Coast Prairies and Marshes Region are found north of Brazoria County in Wharton, Fort Bend, Austin, and Harris Counties (Story et al. 1990).

\section{Ceramic}

The production of pottery generally distinguishes the Ceramic period that occured between AD 100 and 1500 (Story et al. 1990). The integration of pottery production with differences in burials suggests a shift in economic 
and settlement systems. While the development of pottery production began at different times throughout eastern Texas, Story et al. (1990) state that the use of sandy-paste pottery within the project area began around AD 100. The term Mossy Grove has been assigned by Story et al. (1990:256-258) to ethnically distinct groups of the Early Ceramic Period in the region that used sandy paste ceramics and utilized a hunter-gatherer subsistence strategy. Three Mossy Grove sites have been identified within Brazoria County: Caldwell Bend (41BO4), the Oy-1 Site (41BO126), and the Dow-Cleaver Site (41BO35). Grog-tempered ceramics appeared around AD 600. While sandy-paste ceramics persisted, grog-tempered ceramics were predominant until AD 1350. By the end of this period, grog-tempered ceramics were replaced by bone-tempered ceramics and a resurgence of sandy-paste ceramics. Sites within the Gulf Coast Prairies and Marshes Region that contain ceramics from this later period are located in Austin County (41AU36, 41AU37, 41AU38) (Mercado-Allinger et al. 1984).

\section{Protohistoric}

The Protohistoric era spans the time between AD 1500 and 1700 (Patterson 1995:243) and is associated with the arrival of Europeans in the area in 1519. The first European to land was Alonzo Alvarez de Piña, who was commissioned by the Spanish Governor of Jamaica, Francisco de Garayto, to explore the Gulf of Mexico (Mercado-Allinger et al. 1984:9). Contact continued with the 1528 grounding of Spanish explorer Álvar Núñez Cabeza de Vaca's ship near the present-day Brazos and San Bernard Rivers (Story et al. 1990:367). Cabeza de Vaca and three of his men lived for eight years in this region, recording languages and cultural customs from the Atacapan and Karankawa Indian groups (Mercado-Allinger et al. 1983:9). Further contact with Spanish Europeans resulted from Alonso
De Léon's search for the La Salle expedition (Kleiner 2005).

\section{Historic}

The Historic era extends from AD 1700 to the present. During the early eighteenth century, Spanish colonialists would often enter the area of Brazoria County to trade with local Indians and locate lost horses. By the end of the eighteenth century, Spanish colonists began to occupy Texas to stem the flow of French and English incursions into the region (Kleiner 2005).

\section{Settlement of Brazoria County}

Mexico gained independence from Spain in 1821. In an attempt to lay claim to Texas, the Mexican government encouraged Anglo Americans to colonize the region. That year, Moses Austin negotiated a permit which authorized him to bring 300 Anglo American families to Texas. According to the colonization agreement, each family received 4,605 acres of land (one league). Upon his death later that year, responsibility for this proposed colony fell to his son, Stephen F. Austin. Austin chose to establish his colony, known as the Old Three Hundred Colony, along the bottomlands of the Brazos, Colorado, and San Bernard Rivers. Of the families that settled in what is now Brazoria County, most had originated from areas east of the Appalachian Mountains. As a result, they brought with them the traditions and institutions of that region, including the institution of slavery (Kleiner 2005).

One of the first plantations established in Brazoria County was that of South Carolina native Josiah H. Bell, who came to Texas with Austin in 1821 (Weir 2005). He constructed a large plantation on his newly acquired league of land along the Brazos River. Bell became a prominent member of the community, establishing the towns of Marion, also known as 
Bell's Landing, and Columbia as important sites of regional trade. (Edgington 2004:35).

James Briton Bailey, a farmer from North Carolina, was one of the few Anglo settlers living in Texas prior to the arrival of Austin's Colony. After purchasing land from the Spanish government in 1818, he and his family, along with six slaves, established a small cotton farm on the east bank of the Brazos River, near what is now Bailey's Prairie (Weir 2001). A house and a gravesite associated with Bailey's cotton farm have been archaeologically identified and are registered as site 41BO190 (Texas Historical Commission [THC] 2005).

\section{Independence from Mexico}

As the numbers of Anglo American settlers began to increase, so did difficulties with the Mexican government. The settlers, who desired a level of autonomy that would protect their individual and property rights, were angered by the Mexican government's attempt to control their affairs. Having emigrated from Southern states, they brought with them the traditions and practices of their native soil. The Mexican government began to fear that the presence of these settlers would lead to annexation by the United States (Campbell 1989:10-26).

Hoping to put an end to American immigration, Mexico first passed laws prohibiting any future immigration of slaves. In an attempt to circumvent this law, slave owners classified their slaves as indentured servants. The Mexican government responded by passing legislation in 1830 that forbade further immigration, established Mexican troops in Texas, and instituted custom duties and taxes. This resulted in a rise in tensions between the two groups, with skirmishes between Mexican troops and Texas militants occuring at Velesco and Anahuac in 1832 (Campbell 1989:26-30).
Despite these conflicts, Anglo American settlement continued to grow, as did the practice of slavery. Tensions came to a head in 1834 following Mexican president Santa Ana's attempt at centralized control. By the summer of 1835, the colonists were determined to gain independence from Mexico and began preparing for war by establishing an army, declaring independence, and writing a constitution (Campbell 1989:38-40).

Brazoria County played a critical role in the fight for Texas Independence. Shortly after the battle of San Jacinto established independence from Mexico, Brazoria County hosted the Treaty of Velasco in 1836, which instituted peace and Mexico's recognition of the Republic of Texas. The selection of Columbia as the first capital of the Republic further demonstrated Brazoria County’s importance (Campbell 1989:42-43).

Once independence was achieved, Texans continued their practice of slave ownership. The last shipment of slaves arrived at the mouth of the San Bernard River in 1840. At this time, 80 slaveholders resided in Brazoria County and owned 1,316 slaves. The population of Brazoria County increased with the annexation of Texas to the United States in 1845. By 1847, Brazoria County had 1,623 white inhabitants and 3,013 slaves. Between 1849 and 1859, Brazoria County flourished as the wealthiest county in Texas. This was mainly a result of its largely Southern society based on plantation life and slavery. An agricultural system that focused on sugar and cotton production was the foundation for the county's successful economy (Kleiner 2005).

More than 99 percent of the residents of Brazoria County voted for secession from the United States of America in February of 1861. In 1862, fortifications were constructed at Velasco 
and Quintana that were able to sustain Union attacks. While confederate blockade runners were able to operate along the coast and ship cotton overland to Mexico, the presence of federal troops, combined with a loss in cotton profits in 1864, resulted in increasing hardships for county residents. Some plantations were destroyed during the war, and agricultural production dramatically decreased following the emancipation of slaves. Following the Civil War, agricultural recovery was very slow. Principle crops shifted from sugar cane and cotton to corn, grains, potatoes, fruits, and wild grapes; cotton and sugar cane were cultivated for export. In addition to agriculture, cattle raising became an important means of production for many residents (Kleiner 2005).

Prior to the 1940s, the majority of residents made their living from agriculture, with a maximum number of farms totaling 3,065 in 1940. It was during this time that the county's economy was greatly enhanced by the development of rice cultivation. By 1940, the area became the nation's number one rice-producing region with total land used for rice production rising from 6,000 acres to approximately 16,000 acres (Kleiner 2005).

\section{Archaeological Background}

In order to summarize the extent of previously recorded archaeological sites in Brazoria County, the Texas Archeological Sites Atlas (THC 2005) was consulted in April 2005. At that time, 222 archaeological sites had been recorded in Brazoria County, 48 of which contain primarily or solely historic components (Table 21). Due to the large number of sites recorded for Brazoria County, only a brief summary of those sites located within the general vicinity of the Levi Jordan Plantation is presented.
The Levi Jordan Plantation lies in the northwest corner of the Cedar Lane Quad Map of Southeast Texas. A review of the Texas Archeological Sites Atlas indicated that there are approximately 26 previously recorded archaeological sites located in the Cedar Lane Quad Map and in bordering Quad Maps of Sweeny, Brazoria and Cedar Lane NE. Of these 26 sites, 13 (41BO100, 41BO101, 41BO102, 41BO103, 41BO104, 41BO105, 41BO106, 41BO107,41BO108,41BO16, 41BO215, 41BO144, and 41BO191) contain prehistoric components. Two sites (41BO201 and 41BO18) consist of both prehistoric and historic components. Eleven sites (41BO77, 41BO109, 41BO164, 41BO219, 41BO220, 41BO221, 41BO110, 41BO202, 41BO216, 41BO80, and 41BO214) contain historic components. Three of these historic component sites (41BO77, 41BO109, and 41BO164) are plantations established prior to 1835 (see Table 2-1). Numerous other historic plantation sites have been recorded within Brazoria County. Of the 48 sites listed in Table $2-1$, ten consist of historic plantations, which are shown in Figure 2-2 (THC 2005).

\section{Previous Archaeological Investigations at the Levi Jordan Plantation}

From March of 1986 through the end of March 2002, the Levi Jordan Plantation was the subject of archaeological investigations under the direction of Dr. Kenneth L. Brown of the Department of Anthropology at the University of Houston (Brown 2005). Over two decades of archaeological research, in which hundreds of individuals took part, focused on excavations within the slave quarters area and the yard area of the main house (Brown 2005:1). Through these investigations, four blocks of brick slave quarters were found approximately $400 \mathrm{ft}$ north of the main house (Brown 2005:20). Each of these 
Table 2-1. Previously recorded historic sites in Brazoria County, Texas (adapted from Mahoney and Tomka 2004: Table 2-2).

\begin{tabular}{|c|c|c|c|c|}
\hline Site 41BO & Site Name & Site Age & Site Type & $\begin{array}{c}\text { Date } \\
\text { Founded }\end{array}$ \\
\hline 07 & Brock Site & $?$ & House Remains & $?$ \\
\hline 77 & Stratton Plantation & Mexican Republic & Sugar Plantation & 1824 \\
\hline 80 & Ellerslie Plantation & Mexican Republic & Sugar Plantation & 1824 \\
\hline 109 & Sweeny Plantation & Mexican Republic & Sugar Plantation & 1832 \\
\hline 110 & - & Twentieth Century & Artifact Scatter & $?$ \\
\hline 116 & - & Civil War/WWII & Military & 1861 \\
\hline 122 & Velasco Cemetery & Late $19^{\text {th }} /$ Early $20^{\text {th }}$ Century & Cemetery & 1891 \\
\hline 123 & Quintana Cemetery & Late $19^{\text {th }} /$ Early $20^{\text {th }}$ Century & Cemetery & 1895 \\
\hline 124 & Hudgins Cemetery & Late $19^{\text {th }} /$ Early $20^{\text {th }}$ Century & Cemetery & 1909 \\
\hline 127 & - & Antebellum & House Foundation & $?$ \\
\hline 128 & - & Antebellum & House Foundation & $?$ \\
\hline 133 & Patton Plantation (Varner-Hogg) & Mexican/Texas Republic & Sugar Plantation & 1834 \\
\hline 136 & Durazno Plantation & Mexican/Texas Republic & Sugar Plantation & 1840 \\
\hline 147 & - & Late $19^{\text {th }} /$ Early $20^{\text {th }}$ Century & House Foundation & $?$ \\
\hline 151 & Mud Island Fort & Civil War & Military & 1861 \\
\hline 157 & S.S. Acadia & Civil War & Shipwreck & 1864 \\
\hline 164 & Fannin-Mims Plantation & Mexican/Texas Republic & Cotton/Sugar Plantation & 1834 \\
\hline 170 & Ducroz Cemetery & Twentieth Century & Cemetery & 1907 \\
\hline 171 & Gen. C.B. Comstock Shipwreck & Late $19^{\text {th }} /$ Early $20^{\text {th }}$ Century & Shipwreck & 1895 \\
\hline 172 & Lake Jackson Plantation & Antebellum & Sugar Plantation & 1844 \\
\hline 173 & TPC Shipwreck & Twentieth Century & Shipwreck & ? \\
\hline 174 & Dance Gun Shop & Civil War & Industrial & 1850 \\
\hline 175 & Fort Terrell & Civil War & Military & $?$ \\
\hline 177 & - & Twentieth Century & Artifact Scatter & $?$ \\
\hline 178 & - & Twentieth Century & Artifact Scatter & $?$ \\
\hline 183 & George Vancouver Shipwreck & Twentieth Century & Shipwreck & 1942 \\
\hline 184 & William Jamison Farm & Antebellum & Artifact Scatter & 1850 \\
\hline 185 & - & Civil War & Industrial & $?$ \\
\hline 186 & McKinstry House & Mexican Republic & Town Lot & 1830 \\
\hline 187 & Orozimbo Plantation & Mexican Republic & Cotton Plantation & 1824 \\
\hline 188 & Waldeck Plantation & Mexican/Texas Republic & Sugar Plantation & 1842 \\
\hline 189 & Lochridge Village & Twentieth Century & Community & 1913 \\
\hline 190 & Brit Bailey House/Grave & Mexican Republic & House/Grave & 1818 \\
\hline 196 & Brazos Canal & Texas Republic & Corridor & 1847 \\
\hline 199 & - & Twentieth Century & Shipwreck & $?$ \\
\hline 200 & - & Twentieth Century & Shipwreck & $?$ \\
\hline 202 & Pioneer Cemetery & Late $19^{\text {th }} /$ Early $20^{\text {th }}$ Century & Cemetery & 1888 \\
\hline 203 & Bingham House & Twentieth Century & House & 1904 \\
\hline 204 & Providence Plantation & Antebellum & Artifact Scatter & 1827 \\
\hline 212 & - & Late $19^{\text {th }} /$ Early $20^{\text {th }}$ Century & Artifact Scatter & $?$ \\
\hline 213 & Darrington State Prison Farm & Twentieth Century & Trash Dump & 1917 \\
\hline 214 & Palmer General Store & Twentieth Century & Artifact Scatter & 1900 \\
\hline 216 & - & Late $19^{\text {th }} /$ Early $20^{\text {th }}$ Century & Artifact Scatter & $?$ \\
\hline 218 & - & Antebellum & Capped Well & $?$ \\
\hline 219 & - & Antebellum & Artifact Scatter & $?$ \\
\hline 220 & - & $?$ & Artifact Scatter & ? \\
\hline 221 & - & Twentieth Century & Artifact Scatter & $?$ \\
\hline 222 & Bynum Plantation Mill & Antebellum & Mill Foundation & \\
\hline
\end{tabular}




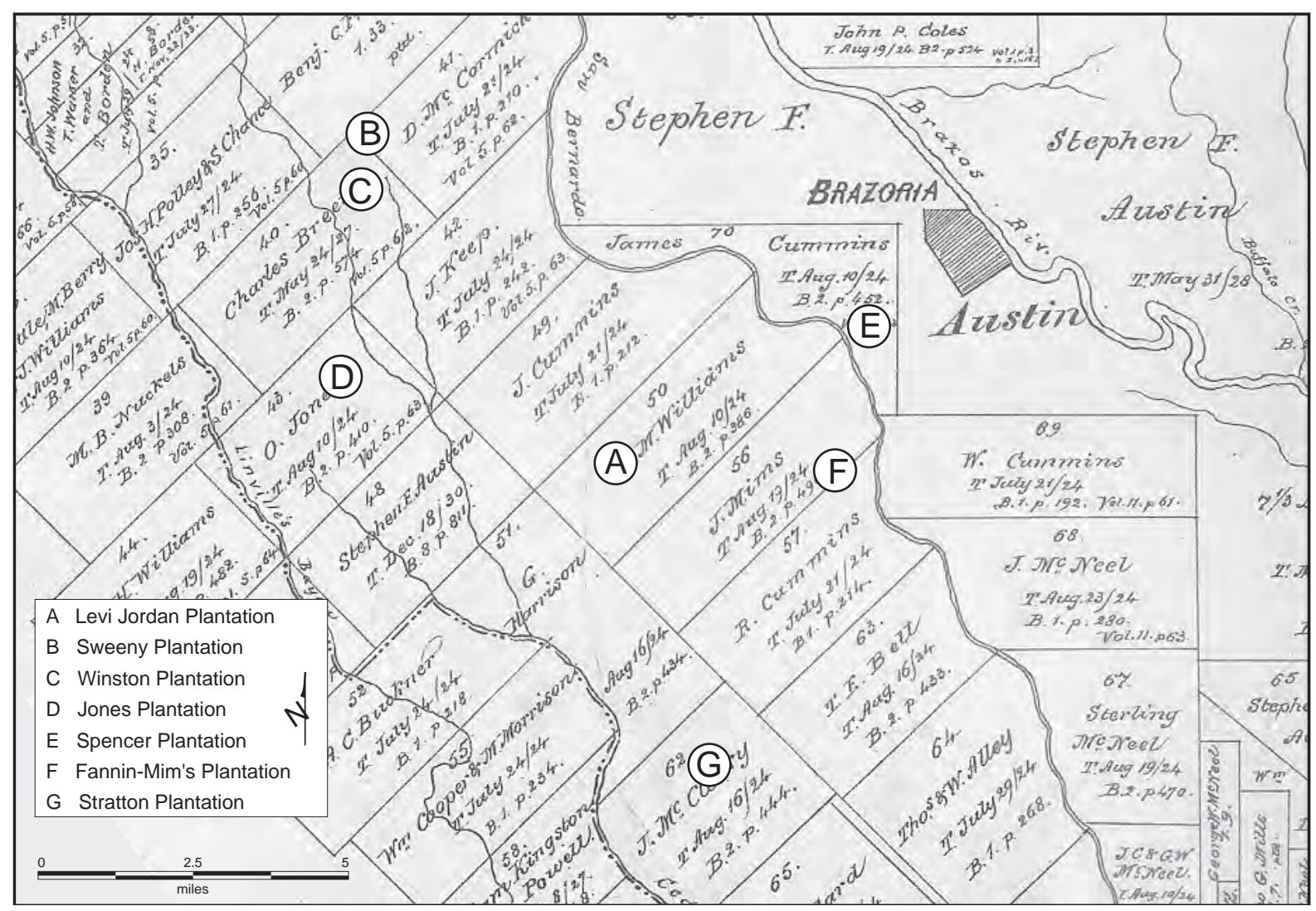

Figure 2-2. Plantations in the vicinity of the Levi Jordan Plantation.

blocks contained six individual cabins (Brown 2005:20-21). Limited investigations were also conducted in the area of the main house, mostly in the back and west side yard area (Brown 2005:26-27). The majority of these investigations were limited to the excavation of shovel test units. During these excavations, Brown located a possible detached kitchen structure and possible house slave quarters (Brown 2005:26-27). TPWD became interested in obtaining the Levi
Jordan Plantation as a result of the discoveries made by Brown and his associates over the last two decades (Brown 2005:1). TPWD intended to obtain the house, land, and associated artifacts in order to create a museum and park on the site (Brown 2005:1). A series of technical reports on the excavations and historical research conducted by Brown, his associates, and students during the 1986-2002 period have been requested by TPWD and are currently in production (Brown 2005:1). 


\section{Chapter 3}

\section{The Development of a Socioeconomic Plantation System in Brazoria County}

In order to fully comprehend the development and history of the Levi Jordan Plantation, it is necessary to first be familiar with the development of the plantation socioeconomic system in Brazoria County. This synopsis provides a history of the development of plantations in Brazoria County with a focus on the growth of slavery, plantation agriculture, and plantation landscapes. A description of the Levi Jordan Plantation landscape is provided, followed by a history of the plantation that concentrates on the antebellum era.

\section{Rise of the Plantation System in Brazoria County}

Historians define a plantation as a farm with 20 or more slaves (Edgington 2004:46) According to this definition, 63 plantations were located in Brazoria County by 1860 (Edgington 2004:46). Many of these plantations grew cotton or sugar exclusively, while others cultivated a combination of these crops. The plantation owners of Brazoria County were some of the wealthiest in the state, and as such owned some of the most impressive plantations in Texas. The majority of these planters arrived in Texas from old Southern plantation states, and brought with them the "inherited attitudes, customs, and methods" employed in a plantation system economy (Curlee 1932:iv). Features of coastal Texas, such as limited transportation, long growing seasons, and high soil fertility, combined with Southern traditions, resulted in the expansion of a plantation system economy in Brazoria County (Edgington 2004:46).

\section{Growth of Slavery}

While slavery was not considered the main catalyst behind the Texas Revolution, the subject unquestionably stirred many of the colonists' objections to Mexican government rule. The rapid growth of slavery following the Texas Revolution demonstrates its important role in the developing economic system of Brazoria County (Figure 3-1).

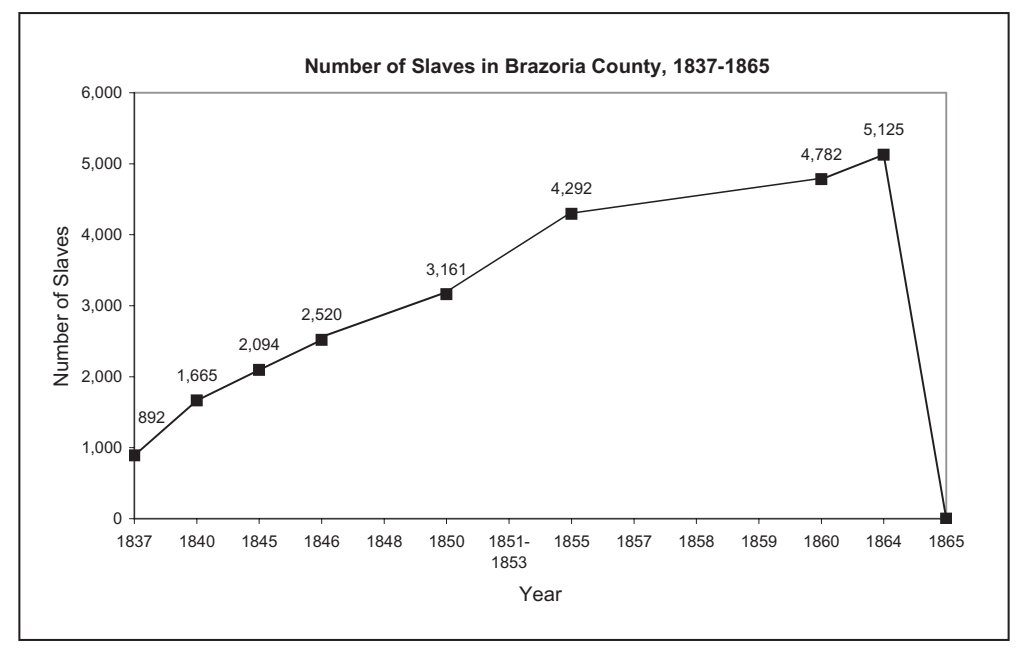

Figure 3-1. Line graph showing the rise and decline of slave numbers in Brazoria County, Texas. 
Although many of the early settlers of Texas came from the South and brought slaves with them, the slave population of Texas in 1825 was only 443; a small amount in contrast to Southern states (Curlee 1932:5). Despite the fact that the Mexican government officially discouraged slave ownership, early Texans took no evident actions to stop the practice. Many settlers arriving in Texas considered slavery necessary for working large farms and plantations in such an unsettled region. Settlers argued that the institution of slavery was vital to developing the land and utilizing the vast agricultural resources of Texas. By the beginning of the Texas Revolution, the use of slave labor was firmly established in Brazoria County (Campbell 1989:50-51).

In the Constitution of the Republic of Texas (1836), the newly formed republic further guaranteed the survival of the institution of slavery:

All persons of color who were slaves for life previous to their emigration to Texas, and who are now held in bondage, shall remain in the like state of servitude: provided, the said slave shall be the bona fide property of the person so holding said slave as aforesaid. Congress shall pass no laws to prohibit emigrants from bringing their slaves into the Republic with them, and holding them by the same tenure by with such slaves were held in the United States; nor shall congress have the power to emancipate slaves; nor shall any slave holder be allowed to emancipate his or her slave or slaves without the consent of congress, unless he or she shall send his slaves without the limits of the Republic. No free person of African descent, either in whole or in part, shall be permitted to reside permanently in the Republic, without the consent of Congress, and the importation or admission of Africans or negroes into this Republic, excepting from the United States of America, is forever prohibited, and declared to be piracy [Section 9, General Provisions].
Many slaves in Texas continued to emigrate with their owners from Southern states. Moreover, planters already established in Brazoria County were able to purchase additional slaves through slave dealers, the majority of which operated in Houston and Galveston (Campbell 1989:52-53).

The number of slaves in Brazoria County continued to grow steadily between the independence of Texas and the end of the Civil War. With the annexation of Texas by the United States in 1846, the number of slaves dramatically increased as large numbers of settlers from the United States began to arrive. This resulted in a disproportionate increase in slaves versus white citizens in Brazoria County. In 1847, 65 percent of the population of the county was composed of slaves, and by 1860 that percentage had increased to 71 percent (Few 1994).

The high percentage of slaves in Brazoria County correlates with the large number of sugar and cotton plantations located in the county. In 1860, there were 63 plantations (Edgington 2004:39). At that time, ten of Brazoria County's slaveowners owned 100 or more slaves. Slaveholders in Brazoria County that owned more than a hundred slaves were invariably planters who used slaves for plantation labor. David G. Mills not only owned the most slaves in Brazoria County, but also in the entire state of Texas, with 344 slaves laboring on three plantations (Campbell 1989:274). Levi Jordan owned 134 slaves who worked on only one plantation (United States Bureau of the Census 1860). Unlike the majority of southern states, which saw a decrease in slave ownership prior to the Civil War, Brazoria County experienced an increase in slaveholders. From 1850 to 1860 the percentage of white slave owners in Brazoria County increased from 51 percent of the county's white population to 56 percent (Powers 1994:44). 
Slavery had such an important role in the economic infrastructure of Brazoria County in part because slave ownership served as a mark of social standing. Slaves in large numbers represented individual wealth. The number of slaves an individual owned often determined economic, political, and social success. While Brazoria County had the third highest number of slaves in the state, only a few slaveholders owned more than 100 slaves (Edgington 2004:37). Many of the largest slave owners of Brazoria County also held powerful positions as lawyers, bankers, and state congressmen. Despite their minority, the wealthy planters of Brazoria County were instrumental in the economic and political direction of the state prior to the Civil War (Wooster 1961:72).

\section{Agriculture and Plantation Economy}

The agricultural potential of Texas greatly influenced the growth of both slavery and immigration to Texas between 1824 and 1861 . Settlers encountered fertile soil and long growing seasons in the coastal counties of Texas. When the United States annexed Texas in 1846, settlers from the South immigrated to Texas in greater numbers (Lowe and Campbell 1987:9). During this period, approximately 75 percent of Texas' white population was involved in agricultural pursuits (Edgington 2004:37).

Due to the abundance of inexpensive land in Brazoria County, many early farmers held more acres of unimproved land than they had in cultivation (Curlee 1932:74). Subsequently, slavery remained the most important factor in the success of a planter; land remained uncultivated without slaves in the field (Edgington 2004:38).

A plantation system economy quickly developed in Brazoria County as a result of settlers' development of land for the production of cotton and sugar. Planters managed the plantations themselves, used a slave foreman, or in the case of large plantations, hired an overseer (Edgington 2004:38). The ratio of planters to farmers in Brazoria County was unlike the rest of the South. Thirty percent of Brazoria County's slaveholders were plantation owners. This percentage was much higher than the rest of the South, where only 12 percent of slave owners were plantation owners (Powers 1994:54).

The establishment of plantations in Brazoria County between 1850 and 1860 resulted in the emergence of the county as one of the wealthiest in the state. The 1860 census lists more than 37,465 acres of cultivated land. Brazoria County led Texas in the total cash value of farms and plantations at $\$ 4,815,603$, with farming machinery adding an additional \$531,717 (Edgington 2004:39).

\section{Cotton Farming}

Cotton farming played a major role in the evolution of a plantation economy in Brazoria County. Cotton production began with the original settlers of Stephen F. Austin's colony in the early 1820s. Stephen F. Austin actively recruited settlers to grow cotton and even stated that he would accept cotton bales as payment for land (Edgington 2004:39-40). The hot climate and fertile soils proved ideal for the production of cotton, and it quickly became the county's primary cash crop (White 1957:256).

Cotton harvest usually began in August. The average slave would pick 150 to 200 pounds a day, working from dawn to dusk for six or seven days a week. Cotton production greatly increased after the invention of the cotton gin in the late eighteenth century. John McNeel, one of Austin's Old Three Hundred Colonists, constructed Brazoria County's first cotton gin in 1828 (White 1957:432-433). By the 1840s, most 
of the large plantations owned their own cotton gins and would let smaller farmers use them for a fee (Edgington 2004:40). With free labor provided by slaves, planters reaped enormous profits from cotton production, which generated much of the success of antebellum plantations in Brazoria County.

\section{Sugar Cane Production}

While cotton was considered the major cash crop, sugar eventually became synonymous with the growth of plantations in Brazoria County. Though never more productive than the sugar cane grown in Louisiana, sugar cane cultivation in Brazoria County became an important aspect of economic life in the region (Edgington 2004:41).

The success of sugar production in Louisiana inspired the early settlers of Texas to make an attempt at its cultivation. John Sweeny was one of the first planters of sugar cane in Brazoria County. He arrived in Brazoria County in 1832 with his family and a large contingent of slaves, and settled along the San Bernard River. By 1844, Sweeny was producing 100 hogsheads of superior sugar (one hogshead equals 1,000 pounds) and over 100 barrels of molasses annually (Edgington 2004:42).

By the early 1840s, several factors combined to spread the cultivation of sugar cane in the coastal region of Texas. The extended growing season was ideal for sugar cane production. In 1840, a cotton worm infestation destroyed half of the region's cotton crop, and floods further decimated the crops in 1842 and 1843. Falling cotton prices, rising cotton tariffs, and the panic of 1837 over the destabilizing of Texas' paper currency further subverted a dependence on cotton production. As a result, more planters began to either supplement their cotton crop with sugar cane cultivation, or switch crops altogether (Edgington 2004:42).
Advances in sugar mill technology and the development of steam-powered mills paralleled the shift toward sugar cane cultivation. The introduction of these steam-powered mills increased planters' investment in the cultivation of sugar cane. Sugar mills were often constructed of brick, and were typically two stories high. Agricultural censuses taken in 1850 and 1860 detail Brazoria County planters making large investments in machinery related to sugar production (Lowe and Campbell 1987:20).

In addition to the higher cost of machinery, sugar production required large numbers of slaves. Planting and processing sugar cane was labor intensive and required many hours of effort. In addition to spending long hours in the fields plowing, planting, and tending the sugar cane crop, slaves had to work round-the-clock shifts in the sugar mills to process the cane into sugar (Edgington 2004:44).

In 1852, sugar production in Brazoria County reached an all-time high with an output of 8,202 hogsheads of sugar (Edgington 2004:44). Records indicate that 29 planters produced sugar that year. The county's investment in sugar mills, slaves, and land totaled $\$ 1,134,000$, an amount indicating the enormous wealth of the planters of Brazoria County (Edgington 2004:45).

\section{Plantation Landscapes and Layouts}

As the majority of Brazoria County's planters had emigrated from Southern states, the layout and landscapes of their plantations often imitated those of the Southern plantations (Edgington 2004:51). While variation existed among Southern plantations, certain trends were evident: sugar plantations were "largely industrial in character whereas cotton plantations often resembled nothing more than oversized farms" (Vlach 1993:193). The majority of plantations included common elements such as a large 
main residence, slave cabins, and outbuildings (Edgington 2004:51). These elements may have clustered together in a gridlike pattern known as the block plan (Rehder 1999), or may have been scattered, with outbuildings and slave quarters closer to agricultural areas located far from the main house (Vlach 1993:6). The placement of these elements conveyed the hierarchy of power on the plantation and reflected the planter's prestige (Edgington 2004:51-54).

\section{Housing}

Home site locations were selected based on availability to water sources. Early settlers of Brazoria County constructed log cabins in the frontier style of the times (Figure 3-2). By the mid-1840s, more elaborate and ornate structures were erected to display increased wealth. These houses served as the focus of the plantation's social hierarchy (Figure 3-3).

Slave quarters usually followed the same evolutionary route as the main houses; they began with log cabins, then evolved to frame or brick structures that lacked all but the barest comforts (Figure 3-4). While quite small in size (16x16 ft at the Levi Jordan Plantation [Brown 2005:21]),

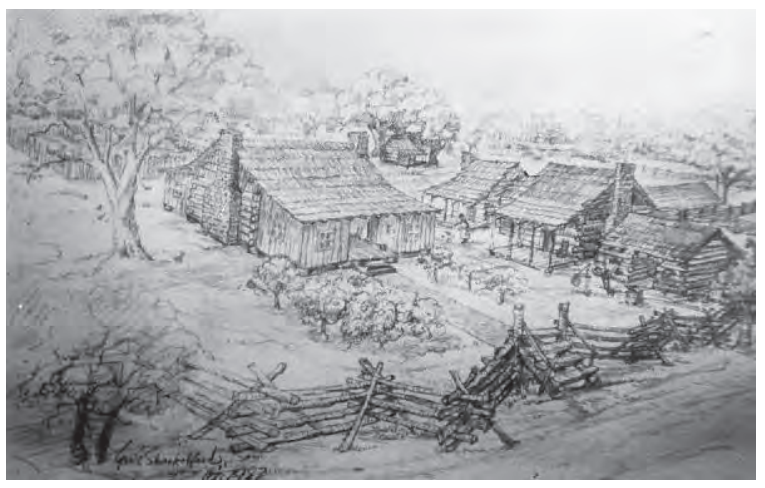

Figure 3-2. George Shackelford sketch of the Bell Plantation (date unknown), Brazoria County Historical Museum Collection <http://www.bchm. org/photos/p390.html>.

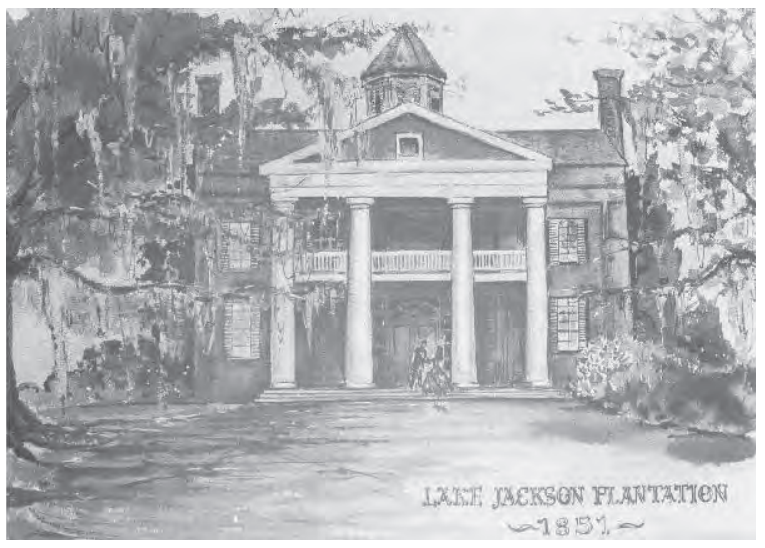

Figure 3-3. Don Hutson painting of the Abner Jackson Plantation main house in Lake Jackson, Brazoria County Historical Museum Collection $<$ http://www.bchm.org/photos/p1184.html>.

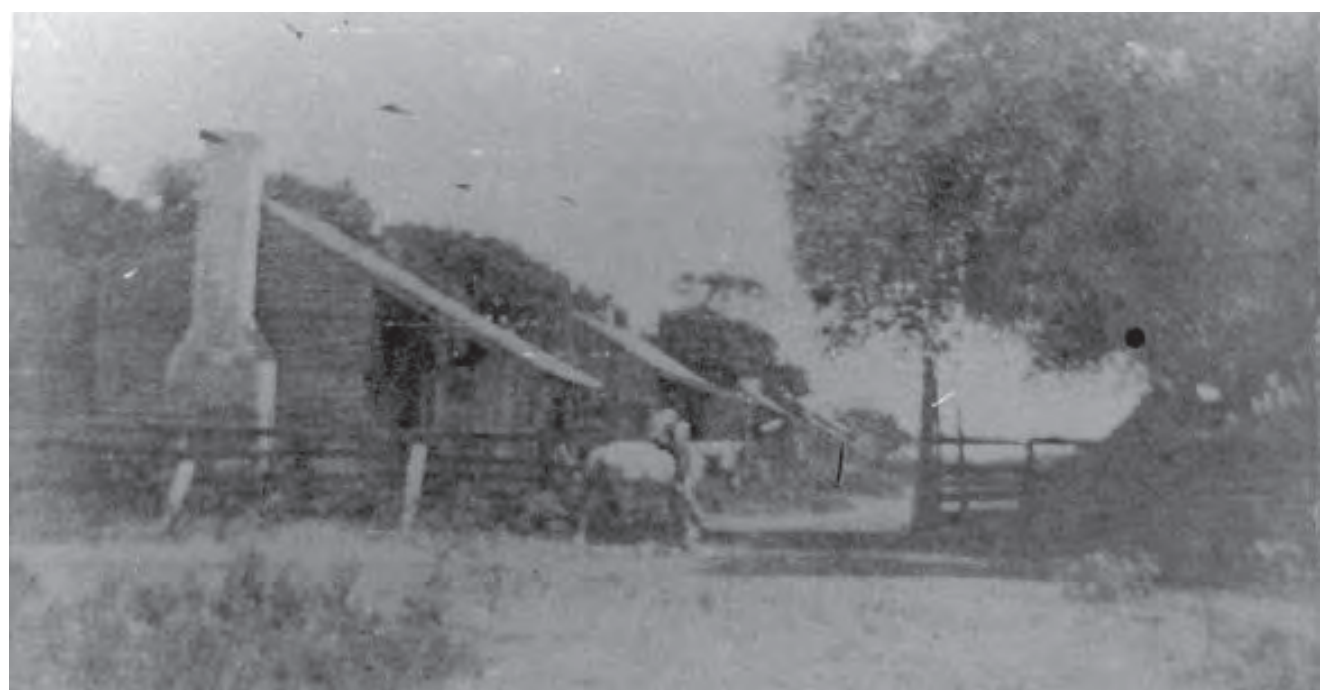

Figure 3-4. 1898 photograph of the slave quarters at the Durazno Plantation near Jones Creek, Brazoria County Historical Museum Collection <http://www.bchm.org/photos/p867.html>. 


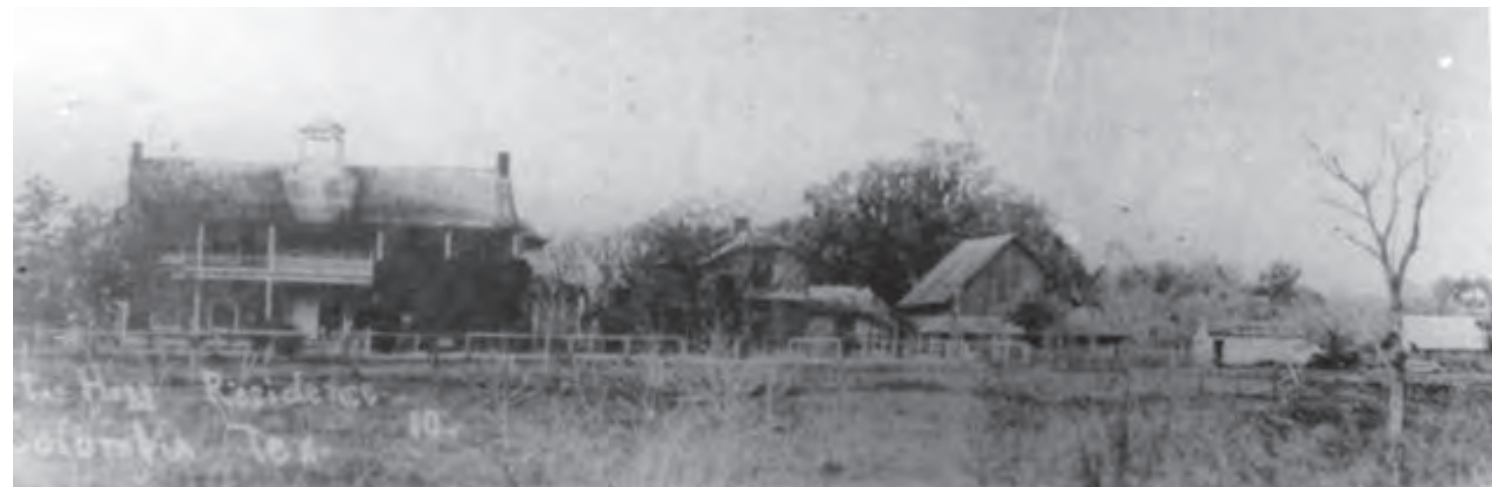

Figure 3-5. Photograph of the Varner-Hogg Plantation, West Columbia (date unknown), Brazoria County Historical Museum Collection <http://www.bchm.org/photos/p2753.html>.

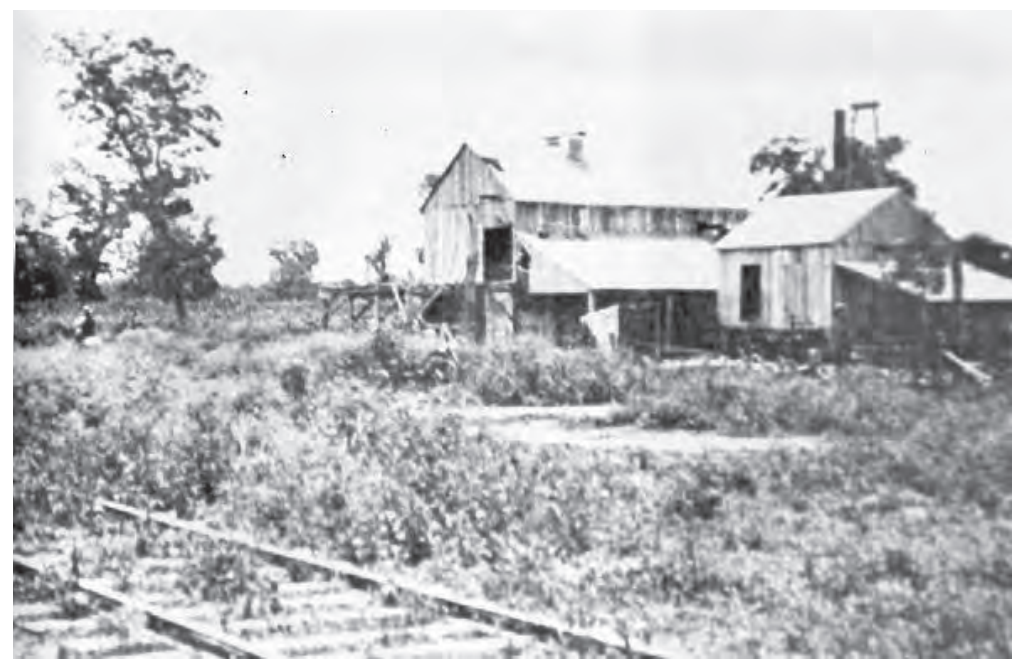

Figure 3-6. Photograph of a cotton gin in Sweeny (date unknown), Brazoria County Historical Museum Collection <http://www.bchm. org/photos/p719.html>.

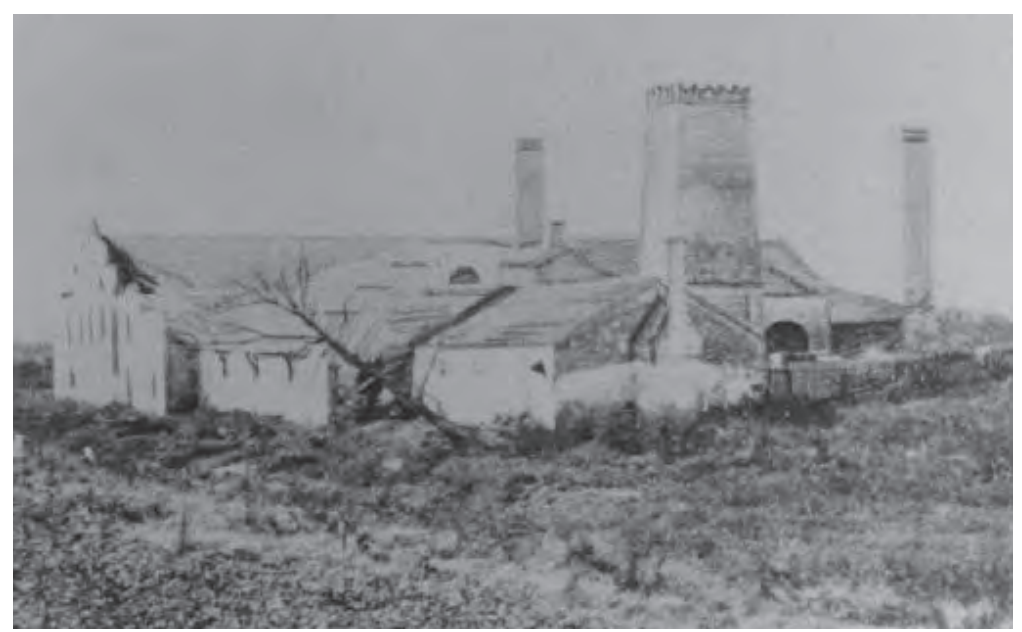

Figure 3-7. Photograph of the sugar mill at the Waldeck Plantation (date unknown), Brazoria County Historical Museum Collection $<$ http://www.bchm.org/photos/p2775.html>. each cabin housed four to eight slaves (United States Bureau of the Census Brazoria County, Slave Schedule 1860). Typically, housing for field slaves was located at a distance from the main house, in close proximity to agricultural fields, while house slaves resided in quarters near the main house (Edgington 2004:51).

\section{Outbuildings}

Outbuildings located on plantations usually included kitchens, smokehouses, stables, barns, corn cribs, and blacksmith shops. They were generally located in a linear arrangement within close proximity to the main house (Vlach 1993:77-78) (Figure3-5). However, sugar mills and cotton gins were located near the fields to facilitate processing, and/or close to rivers, roads, or railroads to ease shipment of products (Figure 3-6). Unlike the small frame construction of the gin mill, sugar mills were twostory brick structures with soaring furnace chimneys (Edgington 2004:42) (Figure 3-7). 


\section{The Levi Jordan Plantation}

\section{Layout of the Levi Jordan Plantation}

Strobel (1926:12-13) describes the Levi Jordan Plantation as having "a large roomy frame house" with "a good brick sugar house and brick cabins for the slaves.” According to Platter (1961), the main residence was a frame house built in 1854. The oak timbers used for construction were obtained from the surrounding forest and from lumber shipped across the Gulf and ferried up the San Bernard River. However, the historical marker (Figure 3-6) states: "Home built in 1848-1851 by slave labor; materials came by sea, Florida to Velasco, and up the San Bernard River.” (Recorded Texas Historic Landmark 1967). These statements are somewhat contradictory and it is uncertain which source correctly dates the construction or identifies the lumber source.

In Platter's 1961 research on mid-nineteenthcentury plantations of Brazoria County, he decribed the main house as unsual for the county: "It was functional and simple to the point of severity" (Platter 1961:159). It is a twostory frame structure with a low-pitched roof and little overhang (Figure 3-9). On each end of the house is a two-story chimney that is flush with the main structure. Platter goes on to describe a front porch that extends across the front of the house on the ground floor. Additionally, two onestory wings extend from the northern part of the house on each end (Platter 1961:159-160).

The two-story wood frame main house stands in stark contrast to the surrounding brick buildings of the working plantation. An architectural description report (TPWD 2003), describes the house as being constructed in the Greek Revival Style that was becoming more popular at the time. Hillard (1990) describes the main houses of cotton plantations as the focal point of the landscape. These buildings were typically constructed of wood in either a 'dogtrot' or 'I' configuration characterized by a central hallway, exterior chimneys at both ends, with full-length verandas or porches across the front and sometimes rear of the house (Hillard 1990:119). The Anglo planters of Louisiana preferred the Greek Revival style during the midto late nineteenth century (Hillard 1990:119).

Platter (1961) states that in addition to the main house, there are brick slave quarters, a cotton gin, a smokehouse, stables, and sugar mill. The sugar mill on the Levi Jordan Plantation is reported to have had the largest sugar making machinery manufactured (Platter 1961:160). It contained two trains of six kettles, each with rollers that were reportedly able to crush sixinch elm logs (Platter 1961:160).

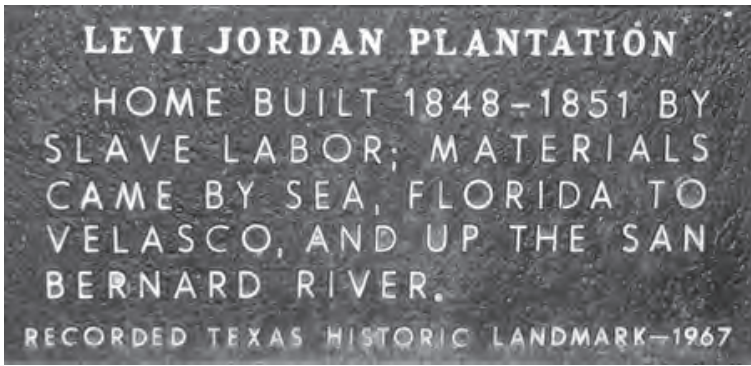

Figure 3-8. Levi Jordan Plantation historical marker plaque.

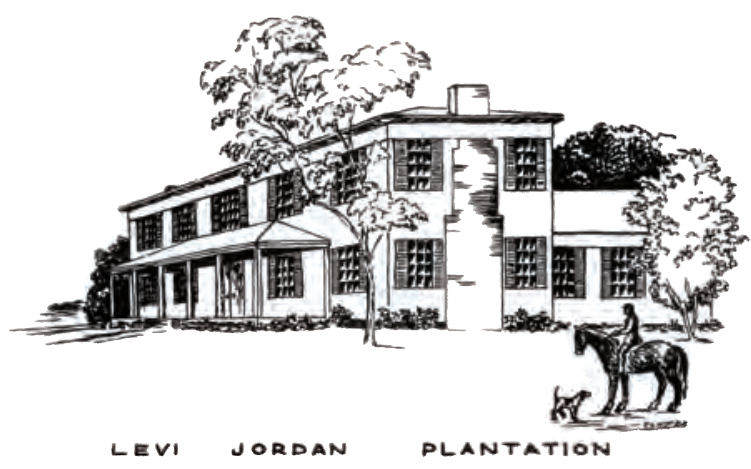

Figure 3-9. Alan A. Platter's sketch of the Levi Jordan Plantation (Platter 1961:158). 


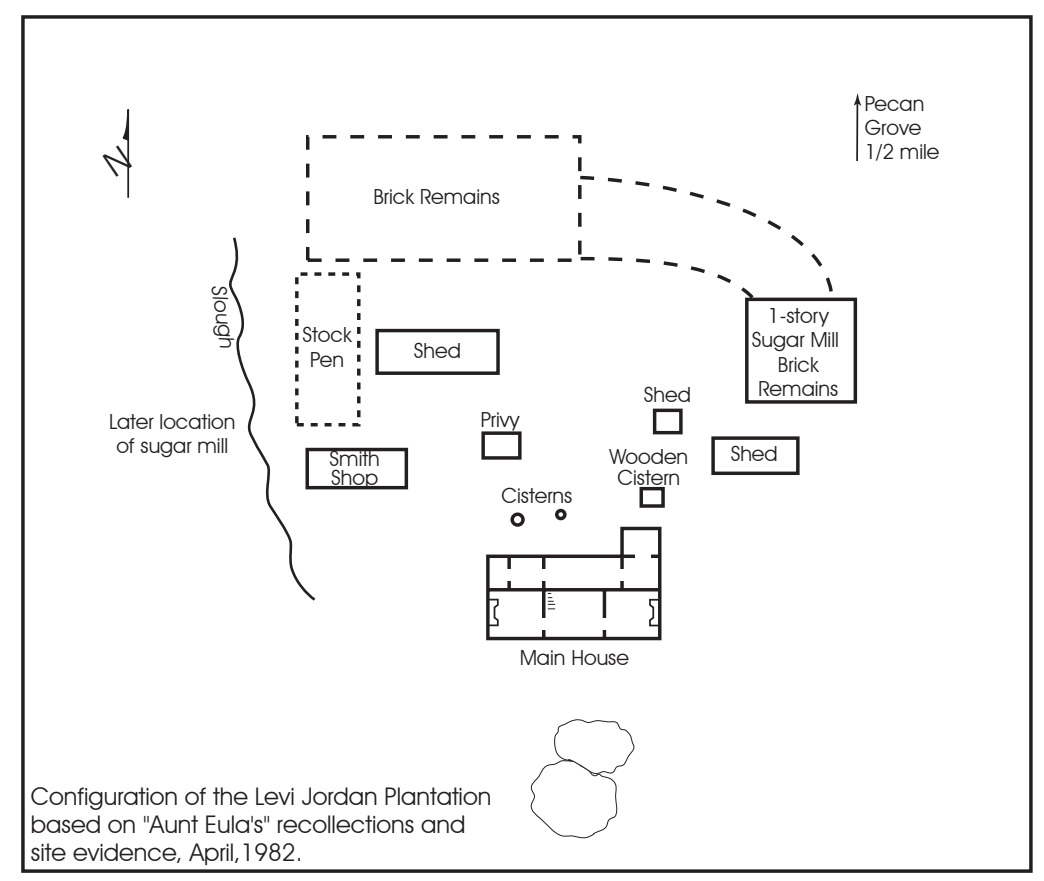

Figure 3-10. Sketch map from the original National Register of Historic Places nomination (adapted from Brown 2005: Figure 2).

The abundance of Houston Black Clay in the area provided an endless and cheap resource for the construction of the plantation's slave quarters and outbuildings. However, in the construction of the main house, Jordan imported expensive woods in order to imitate the house styles of Louisiana plantations. It appears that Jordan's decision to construct the main house of imported woods in the Greek Revival style was a means to display his ample wealth.

A sketch map from the original National Register of Historic Places nomination form identifies and displays the location of several outbuildings (Figure 3-10). These include a blacksmith shop, cisterns, sheds, and brick remains, some of which are labeled "1-story Sugar Mill Brick Remains” (Brown 2005) However, excavations conducted by Ken Brown beginning in 1986 indicated that the brick remains were quarters constructed to house the plantation's slaves (Brown 2005). Further investigations indicated that a total of twenty-nine cabins were constructed in four blocks (three blocks contained six cabins each, while the fourth block contained eight cabins) (Brown 2005: Figure 5). An additional block of four cabins was identified near the main house (Figure 3-11). Brown states that these were originally cabins for the house slaves, but were converted over time into a store, residence, blacksmith shop, and a machine repair shop (Brown 2005). The Levi Jordan Plantation sugar mill has been identified and lies approximately one-third of a mile south of the main house, in an area assumed to be near the original cane fields (Figure 3-12) (Brown 2005: Figure 10). The Jaden Cemetery lies south of there.

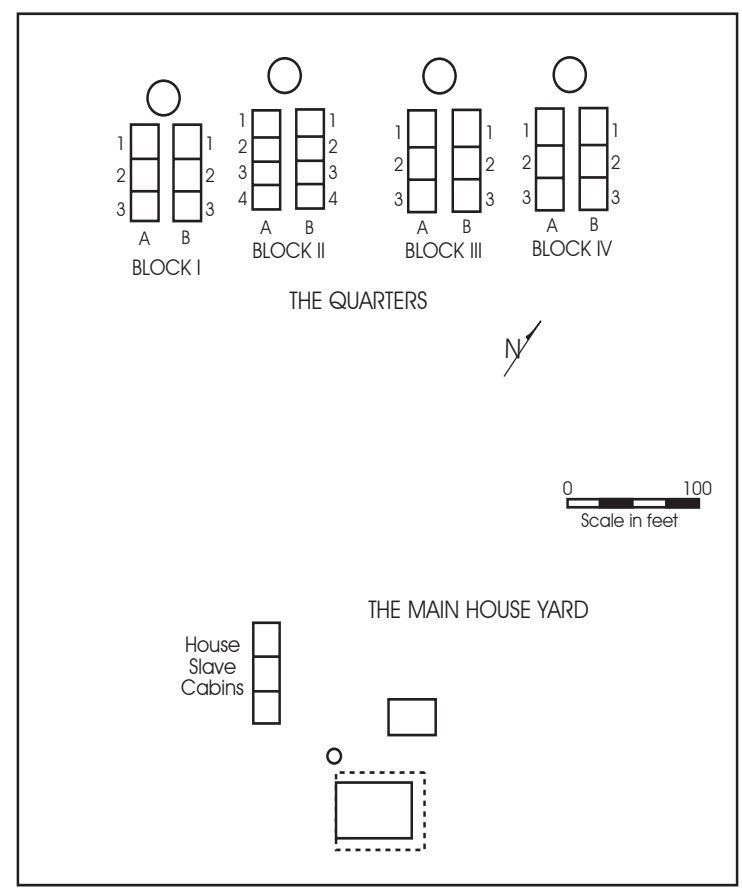

Figure 3-11. Map showing slave quarters and the main house (adapted from Brown 2005: Figure 5). 


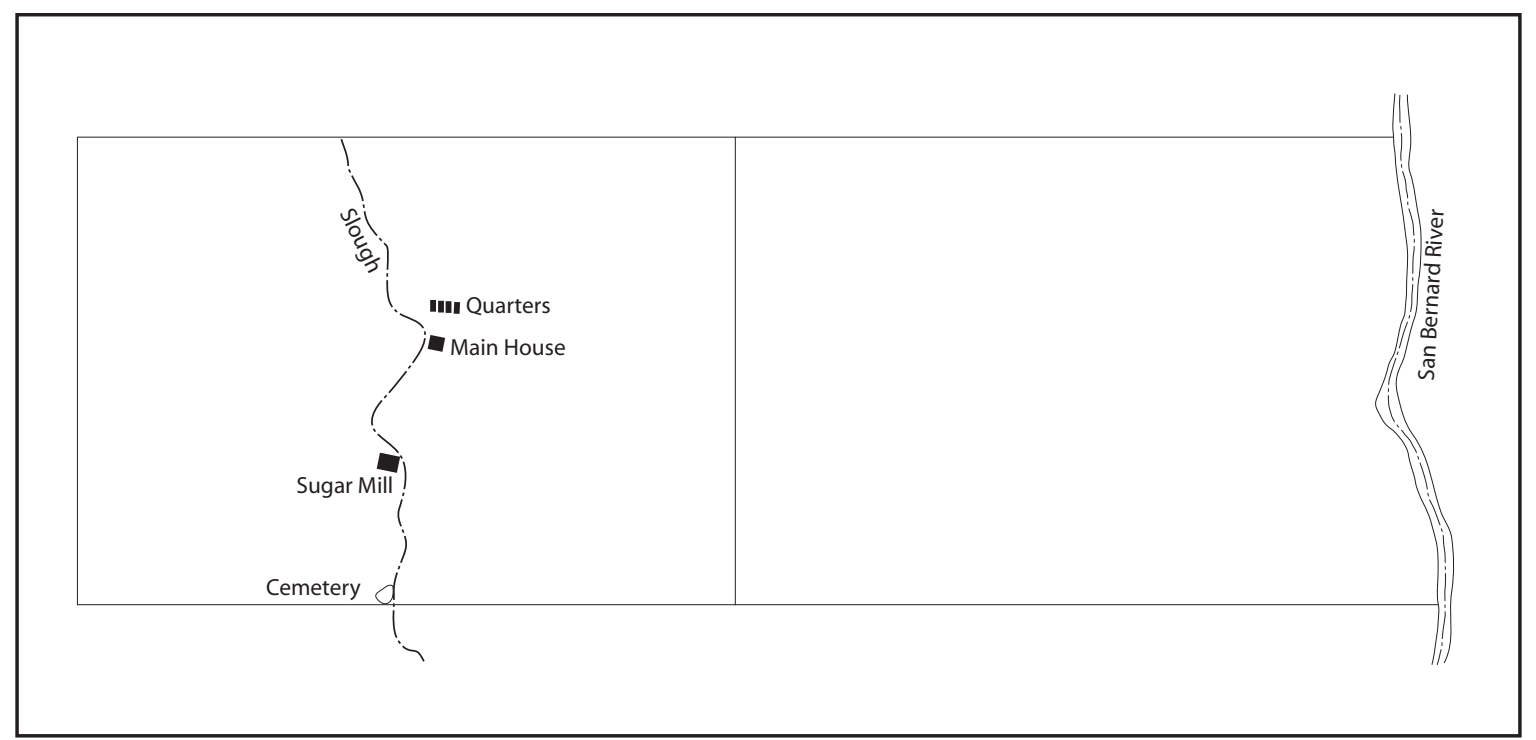

Figure 3-12. Map showing the location of slave quarters, main house, sugar mill, and the Jaden Cemetery on the original plantation lands (adapted from Brown 2005: Figure 10).

\section{History of the Levi Jordan Plantation}

The brief summary of the Levi Jordan Plantation presented here relies heavily on Martha Doty Freeman's (2003) report An Overview of the Development of an Historic Landscape on the San Bernard River, Brazoria County, Texas, and a History of the Levi Jordan Plantation. Some of the information presented in this report contrasts with the historical research presented by Ken Brown and participants of the Levi Jordan Plantation Historical Archaeology Project, 1986-2002 (see Barnes 1999; Barrera 1999; Brown 1994, 2004, 2005; Brown and Cooper 1990; Bruner 1996; Cooper 1989; Garcia-Herreros 1998; Harris 1999; and McDavid 1996, 1997). Freeman's report presents important previously unknown information, and is a comprehensive source in understanding the account of the Levi Jordan Plantation.

\section{Establishment to the Civil War}

Levi Jordan was born to Nathan and Rebecca Wallace Jordan on December 17, 1793, in Wilkes County, Georgia (Figure 3-13). His father died in 1799 and his mother in 1801, leaving their five children orphaned. He married Sarah Stone in 1818 (Figure 3-14). Shortly thereafter, they moved to Lincoln County, Georgia, where their only child, Emily, was born in 1819 (Figure 315). Sometime between 1819 and 1838, the family

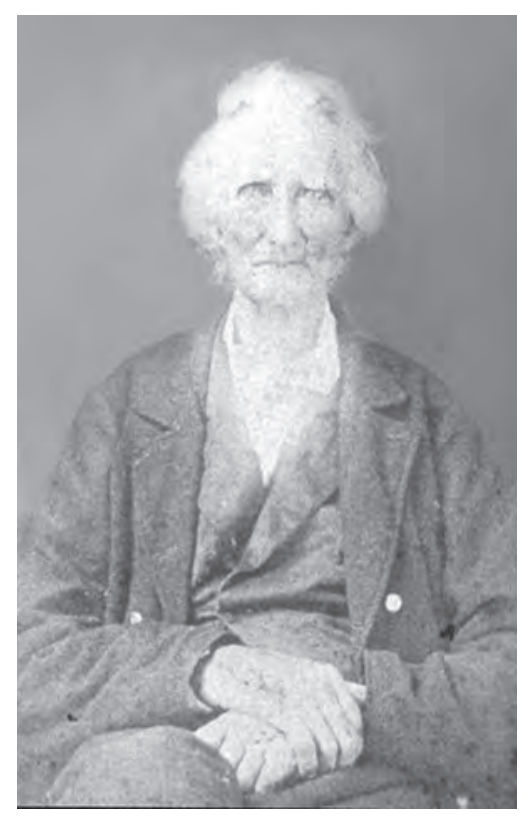

Figure 3-13. Photograph of Levi Jordan (McDavid 1998). 


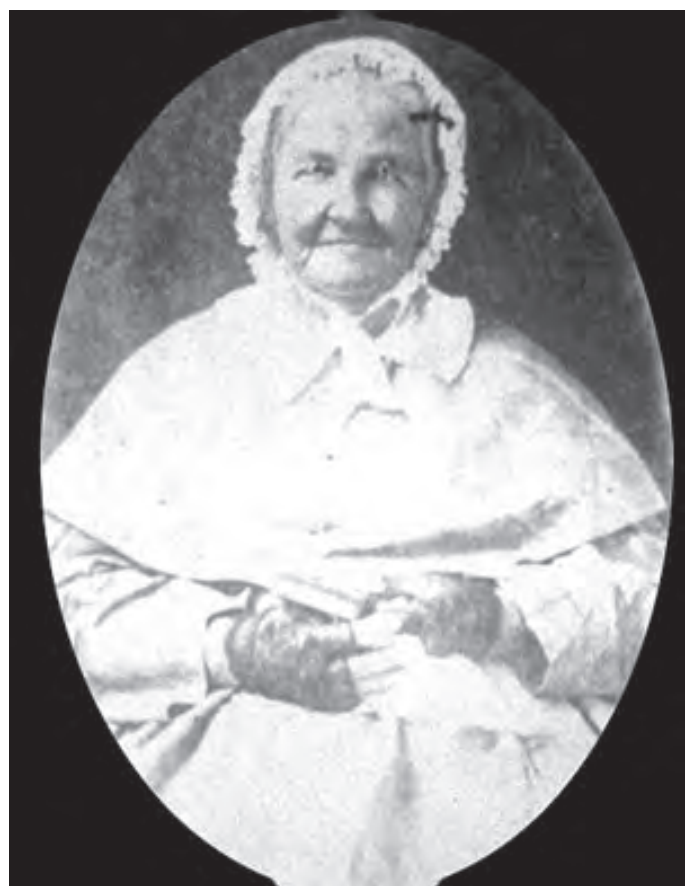

Figure 3-14. Photograph of Sarah Stone Jordan (McDavid 1998).

moved to Dallas County, Alabama. It was there, in 1838, that Jordan's daughter Emily married North Carolina native, James Campbell McNeill (Freeman 2003:107).

By 1840, Emily and her husband had moved to Union Parish, Louisiana, and Levi and Sarah Jordan had established a plantation adjoining theirs across the state line in Arkansas. Between 1840 and 1848, four of their seven children were born on one of these plantations (Figure 3-16). Both the Jordans and McNeills moved to Texas in 1848 (Freeman 2003:107).

When Levi Jordan came to Texas in 1848, he purchased 2,214 acres in the Samuel May Williams land grant for $\$ 8,884$. Family tradition asserts that Jordan chose this particular piece of land because it was where he shot a panther out of a tree (Brown 2005:47). Family tradition also holds that Jordan first came to Texas with slaves, purchased the property, and then returned to Louisiana to collect his family, leaving his slaves behind with his son-inlaw to construct buildings and tend his newly planted crops (Brown 2005:47). At the time of land purchase, a tax assessment for Brazoria County stated that Jordan owned nine slaves, worth \$3,600 at the time (Texas Comptroller Ad Valorem Tax Records, Brazoria County 1848). Historical documents also record a $\$ 10,800$ loan that Jordan made at this time to fellow Brazoria planters, Shadrock and Sarah F. Rowe (Brazoria County Deed Record H:526-528 1848).

There is a continued inconsistency among sources about the amount of acreage that Levi Jordan owned. While the initial tax assessment states that Jordan purchased 2,214 acres worth $\$ 8,884$, other sources list the initial purchase as 2,221 or 2,222 acres (Barnes 1999; Barrera 1999; Brown 1994, 2004, 2005; Brown and Cooper 1990; Bruner 1996; Cooper 1989; Freeman 2003; Garcia-Herreros 1998; Harris 1999; and McDavid 1996, 1997). Later historical documentation states that Jordan's property

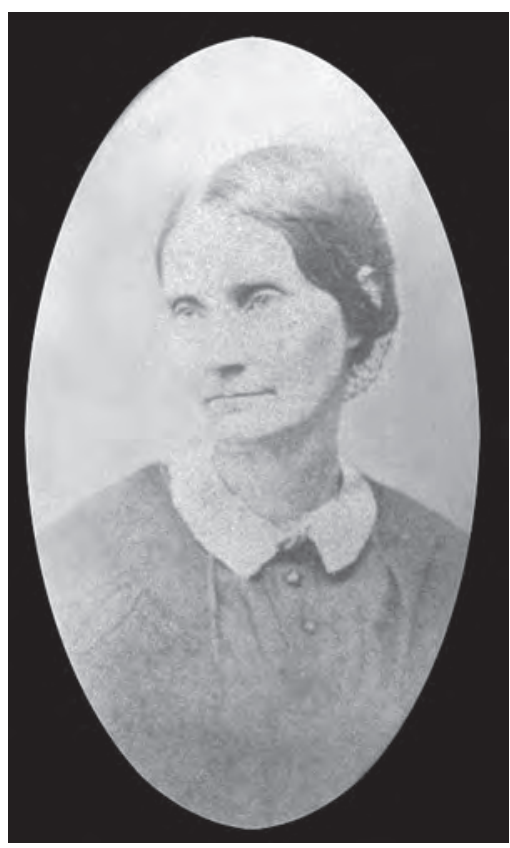

Figure 3-15. Photograph of Emily Jordan McNeill (McDavid 1998). 


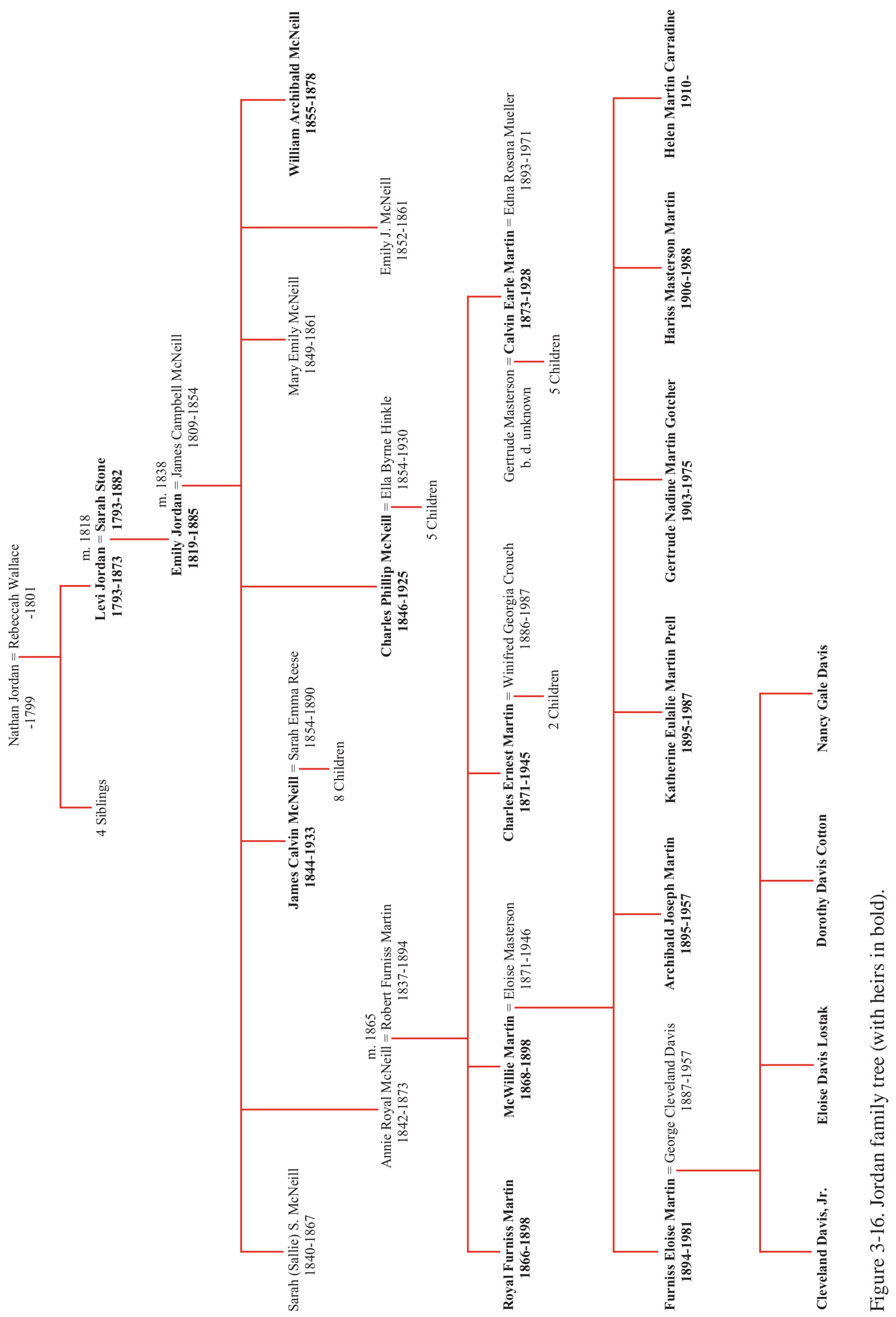


holdings had increased from this initial amount to 2,371 acres in 1850 (Freeman 2003:109). This increase is attributed to his 1850 purchase of 150 acres in the southeast corner of the Rebecca Cumings League (Freeman 2003:109). However, by 1854 he was reported to possess 2,221 acres (Freeman 2003:111), and by the end of the Civil War, Jordan was again recorded to own 2,214 acres valued at $\$ 35,000$ (Freeman 2003:122). Following the death of Levi Jordan, discrepancies again arise on the exact amount of acreage distributed to his heirs and subsequent heirs. The reasons behind these discrepancies are unknown, and may be attributed either to errors in historical documents, inaccurate tax assessments, or unreported sales and purchases of land.

In 1850 Jordan's real estate was valued at $\$ 11,105$ and included a total of 2,371 acres, 150 acres of which Jordan had purchased from John P. Gill on May 23, 1850. His other possessions listed were: 81 Negroes valued at \$30,375; 31 horses valued at $\$ 1,240$; 11 cattle valued at $\$ 44$; and miscellaneous livestock valued at $\$ 740$. Jordan had also made a loan of $\$ 240$, at interest (Figure 3-17). The 1850 tax assessment of $\$ 1,200$ worth of farm machinery may have included a gin, or Jordan may have relied on any one of his neighbors to process his crop. In 1850, while Jordan's neighbors were raising substantial crops of sugar cane, Jordan's moneymaking crop was cotton, with the production of 25 ginned bales weighing 400 pounds each (Figure 3-18) (Freeman 2003:109).

Between 1849 and 1859, Brazoria County flourished as one of the wealthiest counties in the state of Texas, with a Southern society centered on the institution of slavery. The county's economy was dependent upon agriculture, predominately sugar and cotton production. Some of the state's largest and most productive sugar and cotton plantations were established

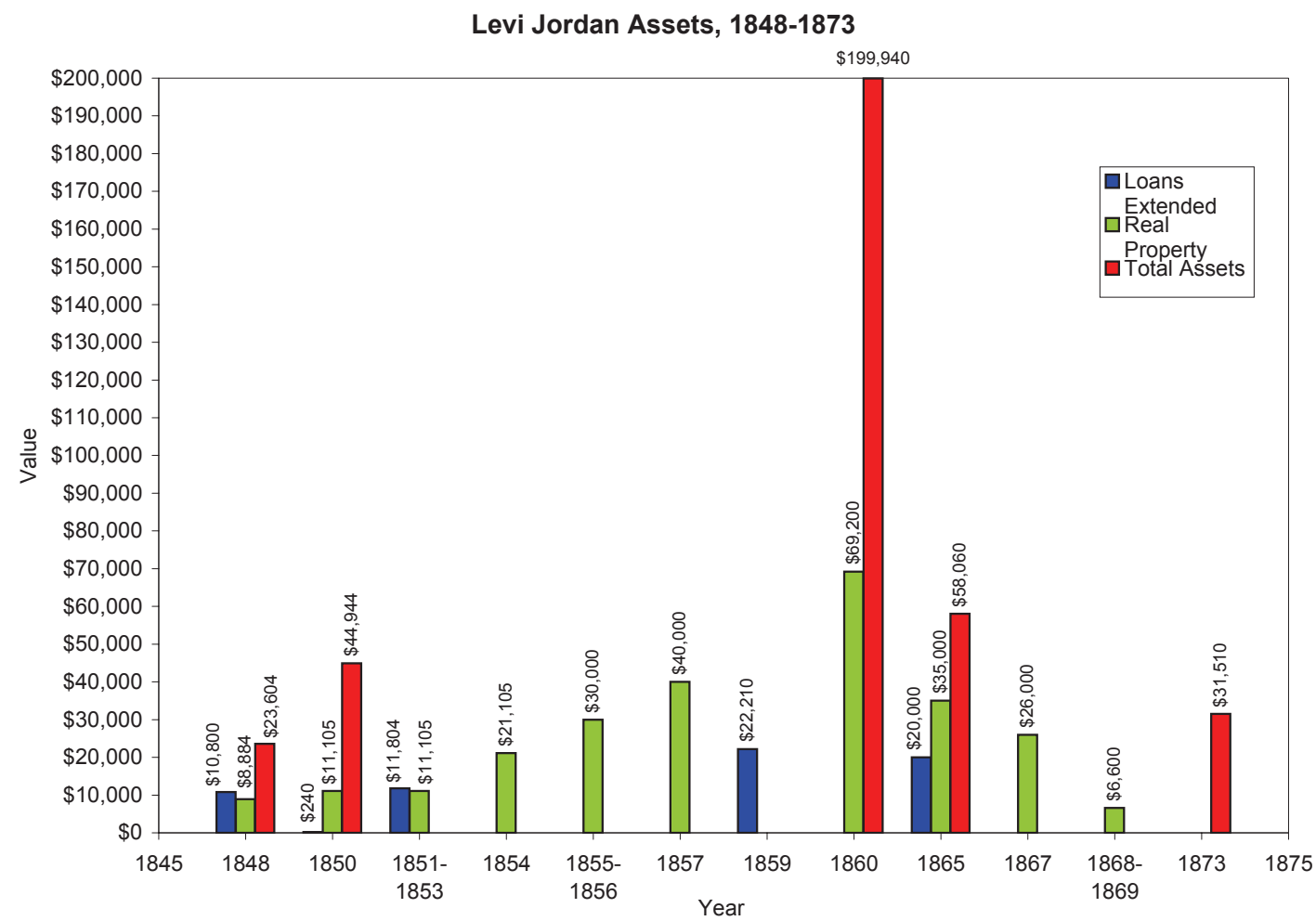

Figure 3-17. Graph of Levi Jordan’s assets, 1848-1873. 


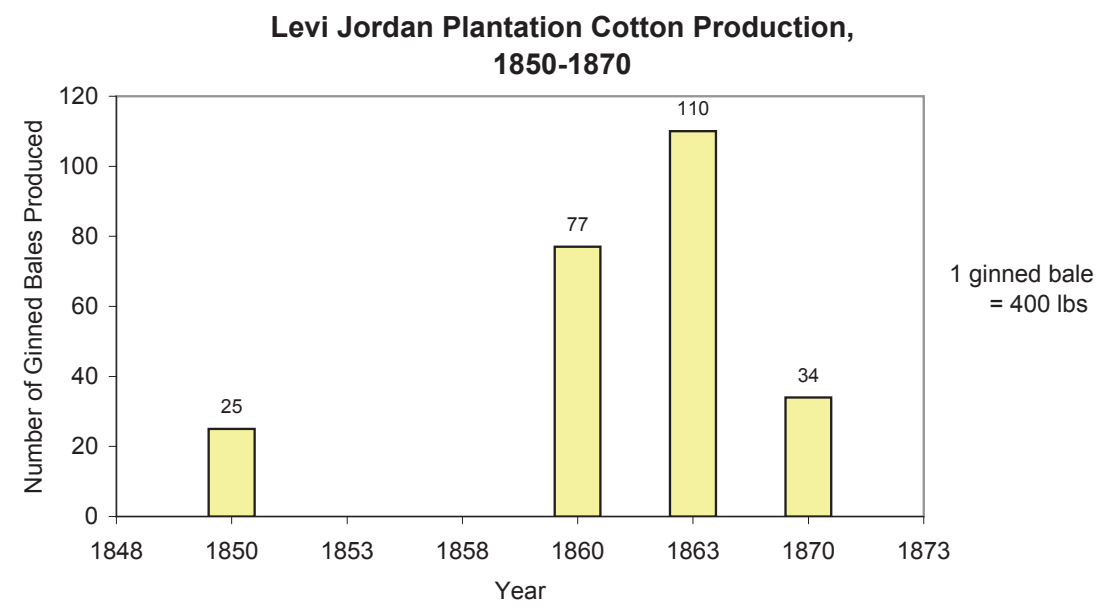

Figure 3-18. Graph of cotton production at the Levi Jordan Plantation, $1850-1870$.

in Brazoria County along the rivers and deep creeks of the area, where crops could be easily shipped to markets by barges.

There was no significant increase in the Jordan's assets between 1850 and 1851. However, the amount of money that he had extended in loans did increase from \$240 in 1850 to $\$ 11,804$ in 1851 (see Figure 3-17). This is a significant amount of money for the time, as it was loaned at an interest rate of 8 to 10 percent. Money lending appears to have been a profitable business for Jordan; indirect evidence suggests that he used this income to invest on plantation improvements (Freeman 2003:111).

While the plantation is not listed as a sugar producer in 1853, an 1853 article in the Columbia Democrat states that Jordan and McNeill produced 100 hogsheads of sugar (Figure 3-19) (Columbia Democrat, 29 November 1853). An increase in the appraisal amount of the plantation suggests that a sugar mill was constructed at this time, a venture that required an investment of a large amount of capital (Freeman 2003:111).

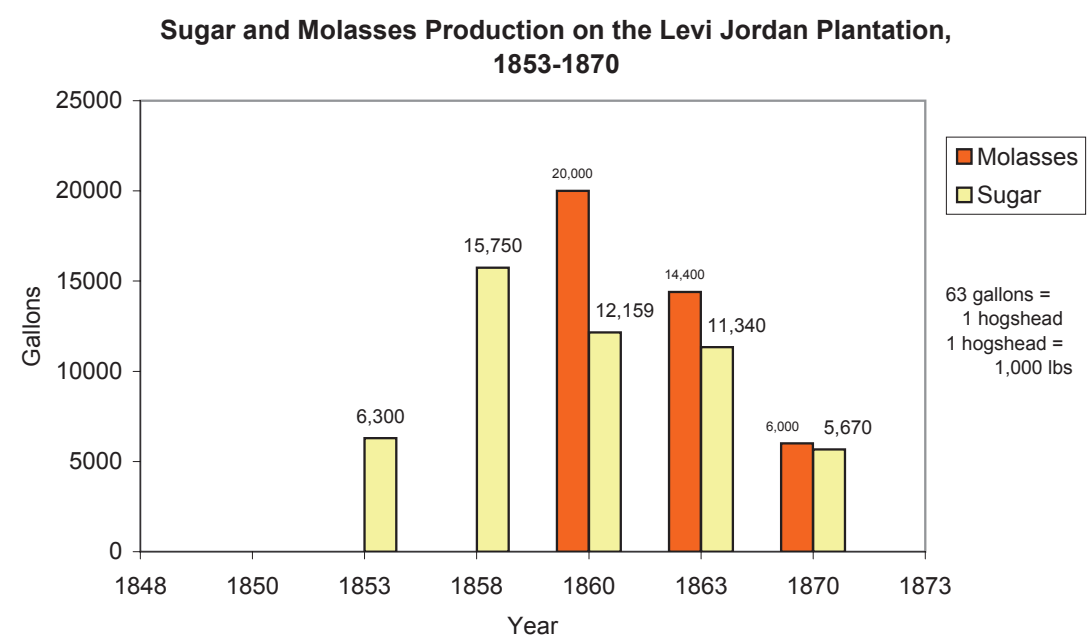

Figure 3-19. Graph of sugar and molasses production at the Levi Jordan Plantation, 1853-1870. 
James Campbell McNeill died on October 28, 1854, ending Levi's business partnership with his son-in-law (Freeman 2003:111). This event did not appear to impede the growth of the plantation. Following his death, there was a notable increase in both the slave population and the plantation's value (see Figure 3-17) (Freeman 2003:112). This last increase included the construction of the Jordan's two-story frame home. Jordan also continued in his role as a money lender to the residents of Brazoria County, doubling the amount of capital he invested in loans (Freeman 2003:113).

Following 1857, Jordan entered an expansion period that witnessed an increased production of sugar. In 1858, Jordan ranked fifth in the county in cane production with 250 hogsheads of sugar (Few 1994). Continued high yields in 1860 were coupled with an increase in improved acreage. His commitment to cane production was reflected by a decrease in corn, sweet potato, and butter production (Figure 320) (Freeman 2003:113).

Between 1850 and 1860 in Brazoria County, there were approximately 19 sugar plantations,
16 cotton plantations, and three plantations that produced both sugar and cotton. Prior to the Civil War, the production of these plantations averaged 7,000 to 8,000 hogsheads of sugar annually, roughly three-fourths of the state's output for 1857. Twenty-six of the county's residents owned more than $\$ 100,000$ in property in 1860. The county's economy and society was focused on plantation life, with the towns of Old Velasco and Quintana serving as resort centers and Gulf seaports. Brazoria's slave population also grew to 5,110 in 1860 , which greatly outnumbered the 2,027 white residents (see Figure 3-1) (Kleiner 2005).

It appears that Jordan also became swept up in the speculation of the slave trade at this time. In spite of extraordinarily high market prices of the time, Jordan increased his holdings from 115 slaves in 1858 to 122 in 1859, and to 134 in 1860 (Figure 3-21). The majority of these slaves were purchased through the services of John Evans. In April of 1859, Jordan gave Evans \$10,000 and sent him to the East Coast to buy Negroes. By the end of June, Evans had yet to return and the family was beginning to question his honesty. Finally, after a seventeen-

\section{Levi Jordan Plantation Production of Miscellaneous Crops, 1850-1870}

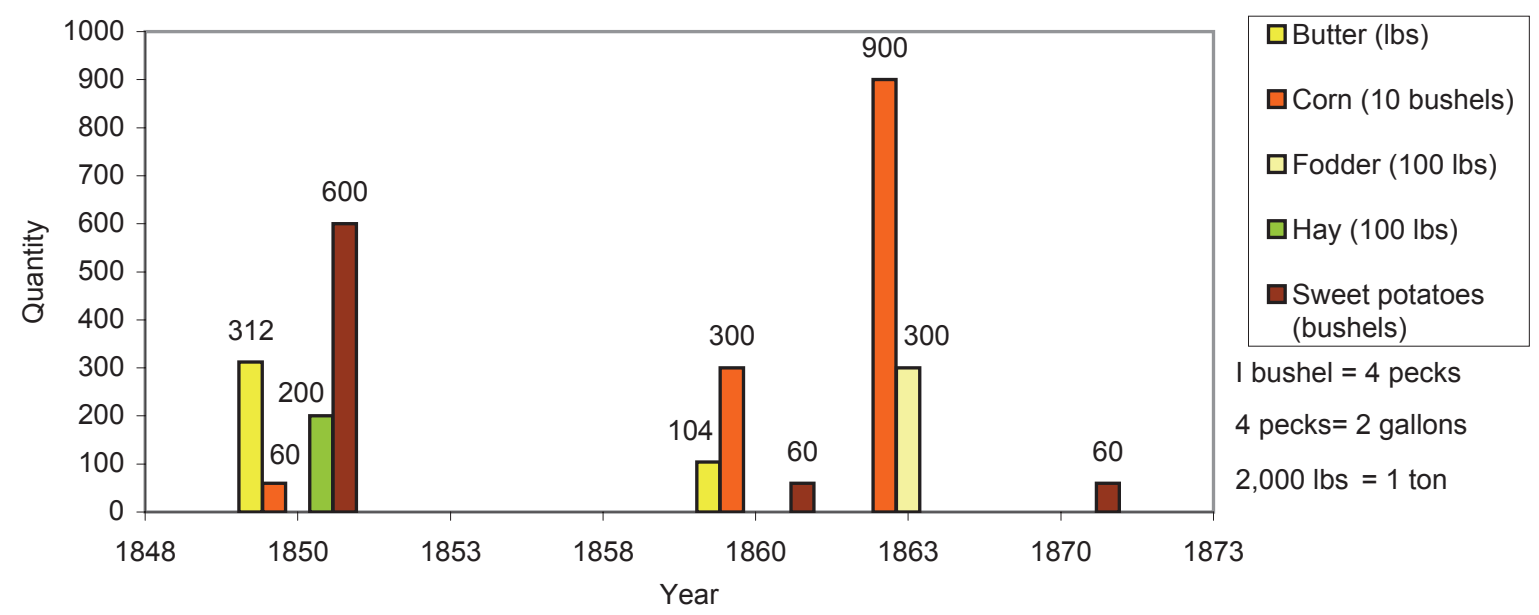

Figure 3-20. Graph of miscellaneous crops production at the Levi Jordan Plantation, 1850-1870. 


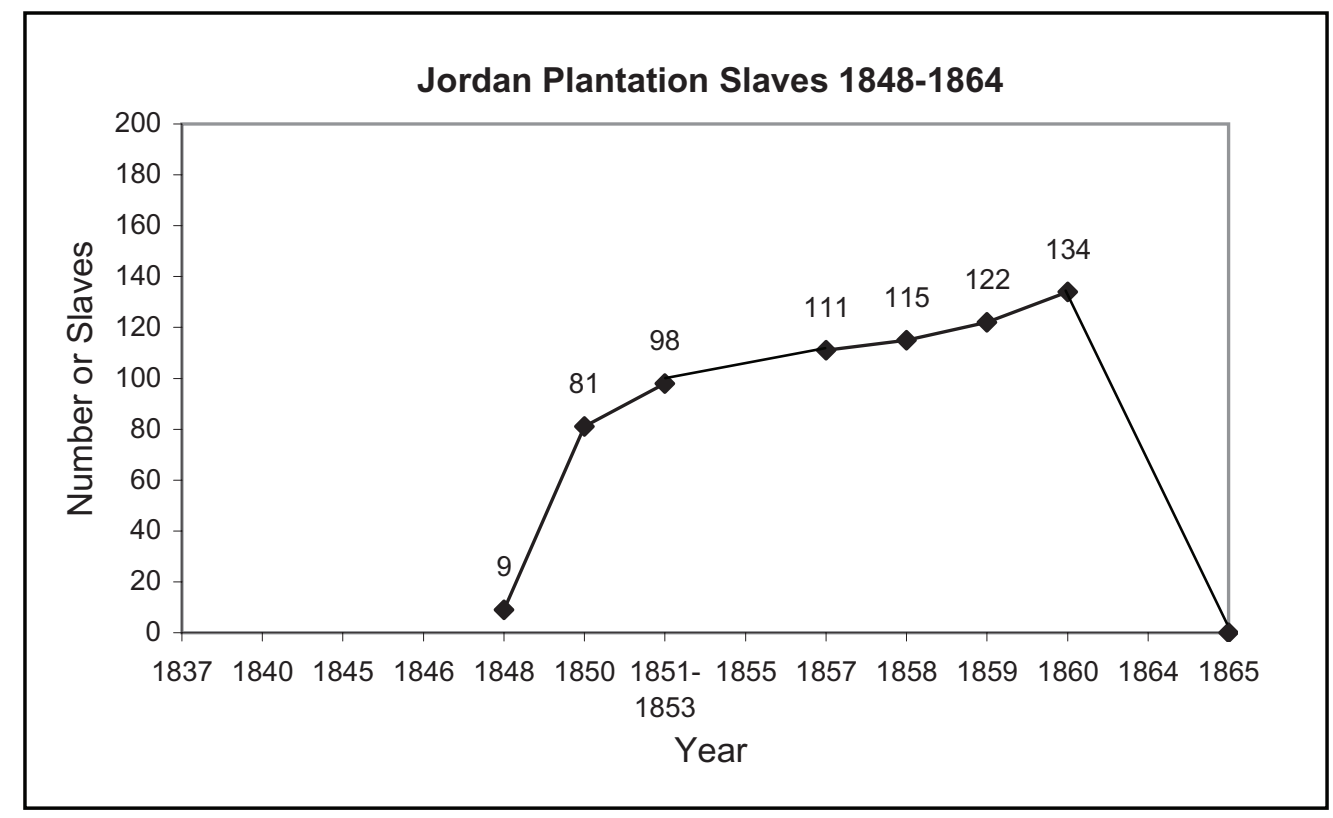

Figure 3-21. Line graph showing the rise and decline of slave numbers at the Levi Jordan Plantation.

month wait, Evans did return with one dozen newly acquired slaves (Freeman 2003:114).

Life on the Levi Jordan Plantation after 1858 was described in detail by the Jordan's granddaughter, Sallie McNeill (see Figure 3-16), in a diary she kept during and after her graduation from Baylor University in Independence, Texas (Raska 1998). Her diary provides an excellent descriptive source of the plantation's architecture. She describes the burning of a slave cabin next to an unoccupied hospital building that also caught fire, as well as other nearby buildings that included slave cabins, cribs, and fences. The constructions of a "new shop before the door," as well as the construction of a carriage house next to the main house were also commented upon in her diary (Raska 1998). Sallie also mentions a porch and an associated piazza. This may have been a configuration in which a ground-floor porch extended across the front of the house and was topped by a small porch that extended across the second floor of the house (Figure 322) (Raska 1998).
Sallie McNeill wrote about growing fears and tensions between 1859 and 1860 as her grandfather continued in his purchase of slaves. Runaways are mentioned for the first time in an entry at the end of December, 1860. Rumors abounded of Negroes rising up against the whites, which resulted in the appointment of vigilance committees and patrols. She also relates a story of a neighbor who was so frightened by her Negro driver that she hid out in the woods. Thus, she felt that the end of slavery was near (Freeman 2003:115-116).

\section{Civil War to Jordan's Death}

On the eve of the Civil War, the Levi Jordan Plantation consisted of Levi and his wife Sarah, now in their mid-sixties; their widowed daughter, Emily McNeill; and Emily's seven children (see Figure 3-16). The 1860 census also lists Robert Stranger, a native of England who was working for the family, and the overseer, D. C. Rathburn of Virginia. By this time, the slave population of the plantation had grown to 134 individuals that resided in 29 cabins (see Figure 3-21) (Freeman 2003:116). It was during this time that Levi 


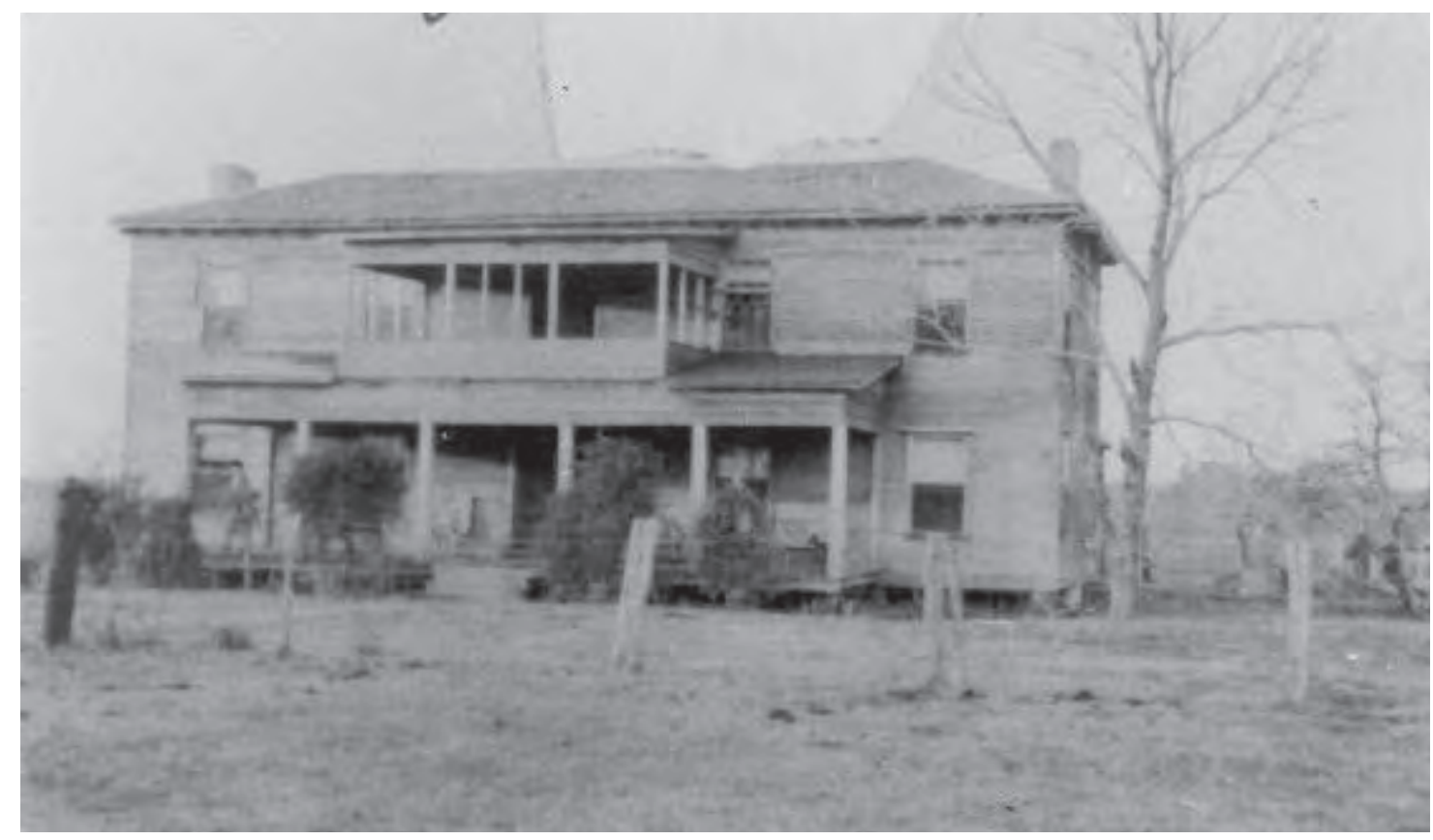

Figure 3-22. Photograph of the Levi Jordan Plantation house showing the front porch (date unknown), Brazoria County Historical Museum Collection <http://www.bchm.org/photos/p1144.html>.

Jordan's recorded wealth was at its peak, with his total property valued at $\$ 199,940$ (see Figure 3-17) (Campbell 1989:274).

While cotton was not listed in the 1860 census (United States Bureau of the Census Brazoria County, Productions of Agriculture 1860), Sallie McNeill makes note of its production in addition to her grandfather's cane crop (Raska 1998). Despite rumors of war and growing political tensions, Jordan placed an order through William Saunders Jr. for a cotton gin in August of 1860 (Freeman 2003:116-117). Jordan appeared committed to continue life as usual despite a vote for secession in February 1861. In fact, he again sent John Evans east of the Mississippi River with an advance of $\$ 10,000$ in September 1861 to purchase additional slaves. Unlike his previous trip, Evans never returned with the slaves, nor with the advanced funds (Freeman 2003:117).

Jordan's grandsons, James and Charles P. McNeill, joined the Texas Cavalry as the war expanded. Despite the loss of his grandsons' assistance withthemanagement of theplantation, cane and cotton production continued at a vast rate. Due to war conditions, however, Jordan was forced at times to sell his sugar in Houston and his cotton to Mexico (Freeman 2003:119). While it may appear that the Jordans fared well through the war, they were forced to deposit capital assets in the amount of $\$ 244,995.75$ in rapidly declining Confederate States Treasury notes between 1862 and 1864. By the end of the war these Confederate States Treasury notes were virtually worthless. Additionally, the Confederate government levied tithes on his agricultural produce (Freeman 2003:120). By the end of the war, the Levi Jordan assets were valued at $\$ 38,060$, with an additional $\$ 20,000$ loaned out at interest. Jordan's household continued to expand with the return of his grandsons from the war effort, and with the 1865 marriage of his granddaughter, Annie McNeill (Figure 3-23), to Robert Martin (Freeman 2003:122). 


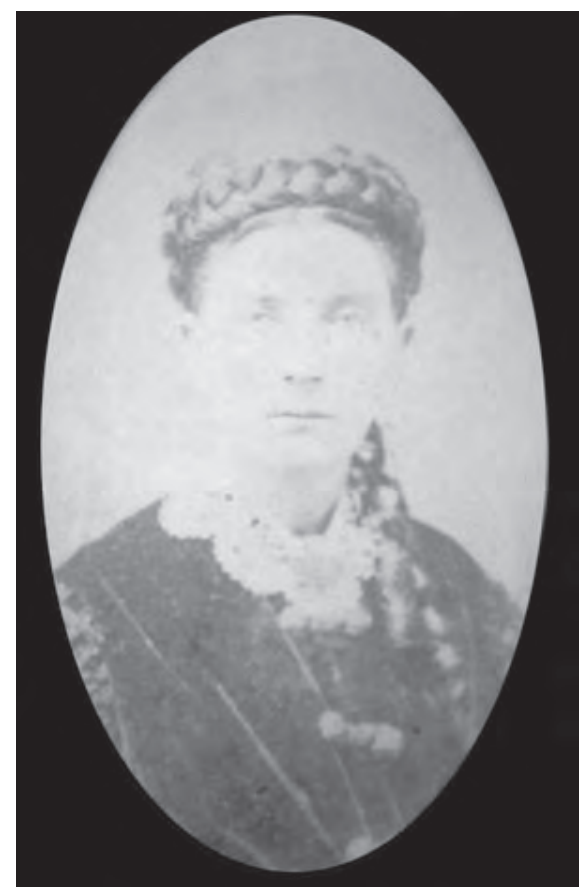

Figure 3-23. Photograph of Annie McNeill Martin (McDavid 1998).

The other residents of Brazoria County did their best to survive the war. Confederate blockade runners operated along the Gulf Coast, and some shipments of cotton were able to be transported to Mexico overland. Despite the little physical damage encountered during the war, residents faced increased hardships due to the presence of federal troops and a drop in cotton profits. While some plantations were destroyed, the greatest blow the to the plantation economy and society of Brazoria County resulted from the emancipation of slaves. Total property value in Brazoria County between 1860 and 1866 fell from \$7 million to less than \$3 million. Many of the grand plantations of the county were divided up into small farms and pastures, while others were eventually converted into prison farms. As conditions worsened, some Brazoria County residents moved to Mexico and established settlements in the Tuxpan River Valley of Veracruz (Kleiner 2005).
In 1865, Jordan's grandsons, James and Charles P. McNeill left the plantation to return to school in Chapel Hill and Virginia. On their behalf, Jordan purchased Shadrock and Sarah Rowe's 715-acre plantation on the western portion of Bell's League. He also purchased the Rowe's cattle herd, and he and his grandsons entered into a cattle business partnership (Freeman 2003:122).

The years between 1865 and 1869 proved to be difficult ones for Levi Jordan. Jordan encountered numerous problems while working with newly freed slaves, in addition to problems collecting money loaned at interest. The new tax structure was also challenging (Freeman 2003:123-124). As a result, the rendered value of Jordan's real estate decreased to $\$ 6,600$ in 1868-1869 (see Figure 3-17). Despite these hardships, Jordan's agricultural report for 1870 was positive; he increased his improved acreage by 50 percent and paid \$5,000 in wages (Freeman 2003:124).

\section{Jordan's Death to TPWD Purchase}

In 1871, at the age of 78, Jordan leased the plantation lands to Robert Stranger, who had worked on the plantation for a time, for the amount of $\$ 10,000$. Jordan also agreed to repair the sugar mill and cane shed for a sum of $\$ 1,400$. Regrettably, Stranger allowed the cane crop to run out and fail; essentially, he ruined the plantation's sugar cane stock. This tragedy was shortly followed by the death of Levi Jordan on February 3, 1873. He was buried in Cedar Lake Cemetery, which was adjacent to James. C. and Charles. P. McNeill’s plantation (Freeman 2003:124).

Jordan left behind a widow, a daughter, three grandsons, one granddaughter, and four greatgrandsons. As two of his grandsons had already received a valuable and fully stocked plantation, the Rowe place, Jordan left all of his community 
interest in the Jordan Plantation to his third grandson, William McNeill. Jordan instructed in his will that William was to share the profits from the plantation with Jordan's wife, Sarah. Jordan's will also stated that the plantation would be managed by Jordan's executors, James and Charles P. McNeill, until William reached the age of majority. Furthermore, his daughter Emily was to live with her mother; however, Annie and Robert Martin were forbidden to enter the home without Sarah Jordan's consent (Figure 3-24). Despite this statement, he left $\$ 5,000$ to be held in trust for the education of Annie’s children (Freeman 2003:125).

As executors of their grandfather's estate, James and Charles P. took over management of the Jordan Plantation, which they found in ruinous conditions. Due to the mismanagement of Robert Stranger, the plantation was bare of cane seed or stock, cotton worms had consumed most of the cotton, the mules used to work the fields were gone, and the fences were in need of repair (Freeman 2003:125). However, by the end of 1874, the McNeill brothers were able to replant the ruined cane fields, improve the plantation's infrastructure, enhance the plantation house, and raise enough cotton to support the family (Freeman 2003:126-127). Also in 1874, their sister Annie passed away, leaving behind four sons, one of which was a newborn (see Figure 3-16). Although Jordan's will forbade Annie and her family from living on the plantation, some of the young Martin boys returned to live at the plantation house after their mother's death. There appears to have been no hard feelings between these two branches of the family, as the McNeills purchased goods from Robert Martin's wholesale business, which he had established in Galveston between 1865 and 1869 (Freeman 2003:127).

The family experienced a small set back in the fall of 1875, when one of the worst hurricanes in memory devastated all the crops in the region. By 1876, William had attained his majority, and his brothers turned over the responsibility of marketing the Jordan Plantation's crops to him and their grandmother, which allowed them to focus on their own property. In December of 1877, Sarah sold her 50 percent interest in the plantation to William for $\$ 1,000$, which gave him full ownership of the entire plantation and all its improvements. Sarah, her daughter Emily, and one or more of the Martin boys continued to live in the main house with William (Freeman 2003:128).

William continued the cultivation and marketing of the Jordan Plantation's cotton

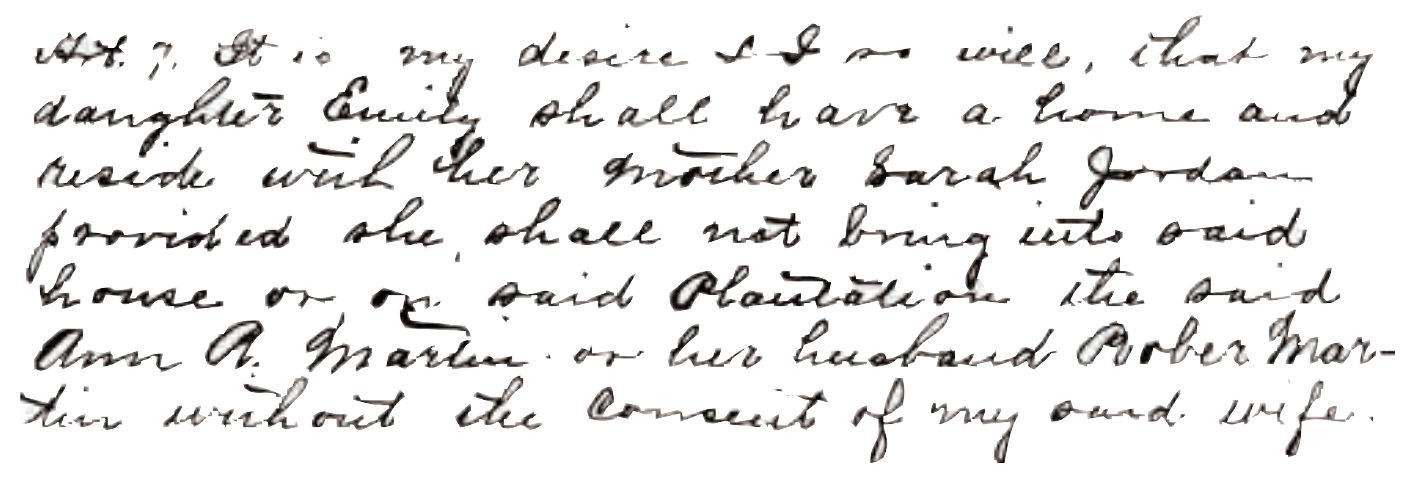

Figure 3-24. Excerpt from Levi Jordan’s will banning Annie Martin and her husband from the plantation (McDavid 1998). 
crop from 1877 until his death in 1878. He died from an infected gun shot wound to his knee that he received while cleaning his guns (Freeman 2003:129). William McNeill's death brought with it an end to the unified ownership and operation of the Levi Jordan Plantation (Table 3-1). Upon his death, it was decided to divide the property among his heirs (see Figure 3-16). Emily McNeill received the northern portion on which the main plantation house was located. The remaining southern half, which contained the sugar mill, was further divided into three lots. One lot each was given to William's brothers, James and Charles P. McNeill, while the third lot was given to his nephews, Royal Furniss, McWillie, Charles E., and Calvin Martin (Figure 3-25). In the belief that the sugar mill and its equipment could not be divided, it and one additional acre was sold at public auction to James and Charles P. McNeill for \$1,000 in July of 1880 (Freeman 2003:130).

Shortly there after, Emily McNeill and the two youngest Martin boys, Charles E. and Calvin, moved to the home of James McNeill and his wife, Sarah Reese. Royal Furniss and McWillie Martin remained with their father, who had recently moved to Weatherford. Meanwhile, the plantation home was rented to Hal Chinn. Because the Martin brothers were minors and their grandmother was unable to manage the operation of the Jordan Plantation, James and Charles P. again stepped in and took over management in 1881 (Freeman 2003:130).

In 1883, Sarah Jordan, the Jordan-McNeill family matriarch, passed away, leaving behind a large family and a vastly changed landscape. By 1884, Emily McNeill deeded the northern half of the plantation and plantation home she had inherited from her son to her grandsons, Royal Furniss, McWillie, Charles E., and Calvin Martin (Freeman 2003:132). Emily McNeill

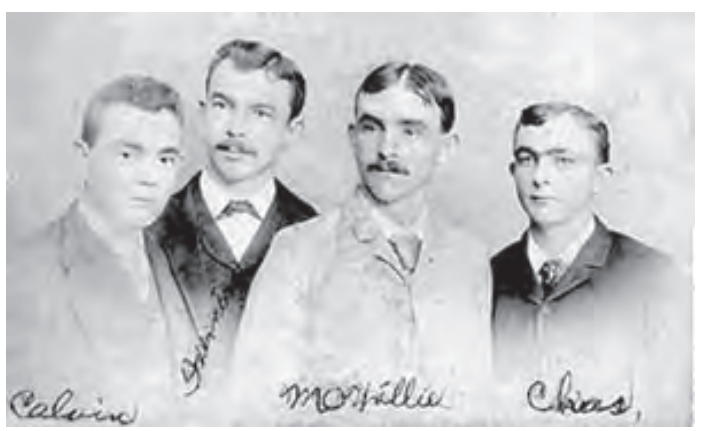

Figure 3-25. The Martin brothers: Calvin, Royal Furniss, McWillie, and Charles (McDavid 1998).

passed away less than a year later in 1885 . Shortly after her death, Royal Furniss, then nineteen, decided to petition the court to be declared no longer a minor to gain management of the plantation he and his brothers owned. This was followed by the resignation of James and Charles P. McNeill's guardianship, though they were still the plantation managers. Robert Martin was then appointed guardian in March of 1886. Soon tensions arose between the McNeills and the Martin brothers. While at school in Velasco, Royal Furniss and McWillie were involved in an accidental shooting. McWillie then left school and returned to Brazoria. Shortly thereafter, Charles E. had a disagreement with his aunt Sarah, and moved out of his uncle's home and into his father's home in Galveston. McWillie, Charles E., and Calvin eventually returned to school in 1886-1888, attending Bryan College at Jordan's bequest. However, McWillie and Royal Furniss met up with trouble again, and were charged with two cases of assault and one case of murder (Freeman 2003:133).

By 1888, Royal Furniss Martin was no longer a minor, and filed a suit in which the McNeill brothers were removed from management of the plantation. As a result, control of the plantation was given to the Martin brothers and the McNeills were made to account for the property they had managed (Freeman 2003:133). The next three years 
Table 3-1. Timeline of ownership of the Levi Jordan Plantation House.

\begin{tabular}{|c|c|}
\hline Date & Event \\
\hline 1848 & $\begin{array}{l}\text { Levi Jordan purchased 2,221 acres in the Samuel May Williams land grant for } \$ 8,884 \text {. He went } \\
\text { into partnership with his son-in-law, James Campbell McNeill. }\end{array}$ \\
\hline $1848-1857$ & Main plantation house was built. \\
\hline 1854 & James Campbell McNeill died, ending the partnership with his father-in-law. \\
\hline 1873 & $\begin{array}{l}\text { Levi Jordan died on February 3. In his will, Levi equally divided the plantation and its } \\
\text { proceeds between his wife, Sarah Stone Jordan, and his grandson, William Archibald McNeill. } \\
\text { Management of the house and yard was granted to Sarah Stone Jordan until her death. } \\
\text { Management of the plantation was assigned to James Calvin and Charles Phillip McNeill until } \\
\text { William reached the age of majority. }\end{array}$ \\
\hline 1876 & William Archibald Jordan took over the management of the Jordan Plantation. \\
\hline 1877 & $\begin{array}{l}\text { Sarah Stone Jordan sold her } 50 \text { percent interest to William Archibald Jordan for } \$ 1,000 \text {, which } \\
\text { made him the sole owner of the Levi Jordan Plantation. }\end{array}$ \\
\hline 1878 & $\begin{array}{l}\text { William Archibald Jordan died, leaving the plantation divided among his heirs: } \\
\text { Emily Jordan McNeill received the northern portion of the plantation, including the } \\
\text { plantation house; } \\
\text { The southern portion was left to William's brothers and nephews; } \\
\text { Management was assigned to James Calvin and Charles Phillip McNeill until the Martin } \\
\text { brothers were of age }\end{array}$ \\
\hline 1880 & The house was rented to Hal Chinn. \\
\hline 1883 & Sarah Stone Jordan passed away. \\
\hline 1884 & $\begin{array}{l}\text { Emily Jordan McNeill deeded her portion of the plantation land and plantation house to her } \\
\text { grandsons. }\end{array}$ \\
\hline 1885 & Emily Jordan passed away. \\
\hline 1888 & $\begin{array}{l}\text { Royal Furniss Martin, no longer a minor, filed a suit to have James Calvin and Charles Phillip } \\
\text { McNeill removed as managers }\end{array}$ \\
\hline 1891 & $\begin{array}{l}\text { The northern portion was divided among Royal Furniss, McWillie, and Charles Ernest Martin, } \\
\text { with McWillie Martin receiving the parcel that the plantation house was on. }\end{array}$ \\
\hline 1937 & McWillie Martin died. \\
\hline 1946 & $\begin{array}{l}\text { Eloise Masterson Martin, wife of McWillie Martin, died, leaving the plantation and the } \\
\text { surrounding acreage undivided to their children }\end{array}$ \\
\hline 1978 & $\begin{array}{l}\text { Land was partitioned with Furniss Eloise Martin Davis receiving the } 70.5 \text { acres with the } \\
\text { Jordan Home }\end{array}$ \\
\hline 1981 & $\begin{array}{l}\text { Furniss Eloise Martin Davis passed away, leaving the property to her children, Cleveland } \\
\text { Davis, Jr., Eloise Davis Lastok, Dorothy Davis Cotton, and Nancy Gale Davis. }\end{array}$ \\
\hline 2002 & Texas Parks \& Wildlife Department acquired the property. \\
\hline
\end{tabular}


witnessed a flurry of suits and countersuits. The ultimate determination of the courts was that the Martins owned the northern half of the original Jordan Plantation, including the parcel upon which the plantation house was located, along with 369 acres in the southern half (Freeman 2003:133-134). In October of 1891, the northern half of the plantation was further divided between Royal Furniss, McWillie and Charles E. Martin. The parcel that contained the Jordan Plantation home was deeded to McWillie. Calvin retained ownership of the 369-acre lot in the southern half of the original plantation (Freeman 2003:134).

Shortly after the end of 1894, McWillie Martin moved into the Jordan Plantation home with his wife Eloise Masterson and their children (see Figure 3-16). The house remained in relatively intact condition until the hurricane of 1900, which removed the kitchen-dining room annex, damaged the first floor on the south, east and north sides, and damaged the roof. As a result, the roof was replaced and the kitchen rebuilt (Freeman 2003:134).

McWillie Martin died in 1937, followed by the death of his wife, Eloise in 1946, leaving their estate in undivided interest to their children. In 1978, the land was further partitioned with Furniss Eloise Martin Davis, McWillie Martin's oldest child, receiving the portion on which the Jordan Plantation home sits (Freeman 2003:134). Following her death in 1981, the property went to Cleveland Davis Jr., Eloise Lostak, Dorthy Cotton, and Nancy Davis (see Figure 3-16) (Freeman 2003:134-135). The property was then acquired from these owners by the Texas Parks and Wildlife Department on March 15, 2002 (Freeman 2003:135). 


\section{Chapter 4}

\section{GoAls \& Methods}

When TPWD purchased the Levi Jordan Plantation in 2002, it was with plans to develop it into a state historic site. The main plantation house, which is the only intact building on the plantation, would function as the focal point of the park, with a visitor center, parking lot, access road, and maintenance yard located nearby. As the first step toward developing the site, TPWD must obtain archaeological information on the historical development of the plantation's main house and surrounding structures. While this information will eventually be used for visitor education, it is more immediately necessary for the continued guardianship, interpretation, and management of the property.

\section{Goals}

The objectives of this investigation are: to gather data relating to the construction sequence of the house, including the original layout, construction dates, and changes made to the building; to obtain information on the location and function of possible outbuildings and features; and to provide archaeological clearance prior to construction in the area proposed for visitor and maintenance use.

TPWD determined seven areas of focus for this archaeological investigation. The areas were divided into zones, which CAS designated Zones A, B, C, D, E, G, and Z. Zones $A$ through $G$ are located in, around, and near the plantation's main house (Figure 4-1), while Zone $\mathrm{Z}$ encompasses the area proposed for visitor center development (Figure 4-2).

\section{Field Methodology}

To accomplish the goals of this investigation, CAS employed a combination of pedestrian survey, shovel test placement, and test unit excavation. All test units measured $3 \times 3 \mathrm{ft}$ (just under $1 \mathrm{x} 1$ meter) and were excavated in 4-inch (roughtly $10 \mathrm{~cm}$ ) levels. A datum was established for each unit and depths were measured in inches below datum (inbd). CAS staff excavated 14 units underneath, adjacent to, and near the main house. In the area scheduled for visitor use and maintenance, CAS conducted a pedestrian and shovel test survey and excavated a single test unit. All measurements from this project were recorded using English units, following a long-standing tradition of using the English system of measurement when dealing with historic properties in Texas. This practice greatly facilitates correlating data with historical documents, as this was the system used builders and occupants of the plantation.

Site maps were recorded that showed locations of site boundaries, units, datums, shovel tests, features, and areas of interest. A field sketch of shovel test locations was prepared, while additional mapping data was collected using a GPS unit. The locations of exterior excavation units were recorded and 


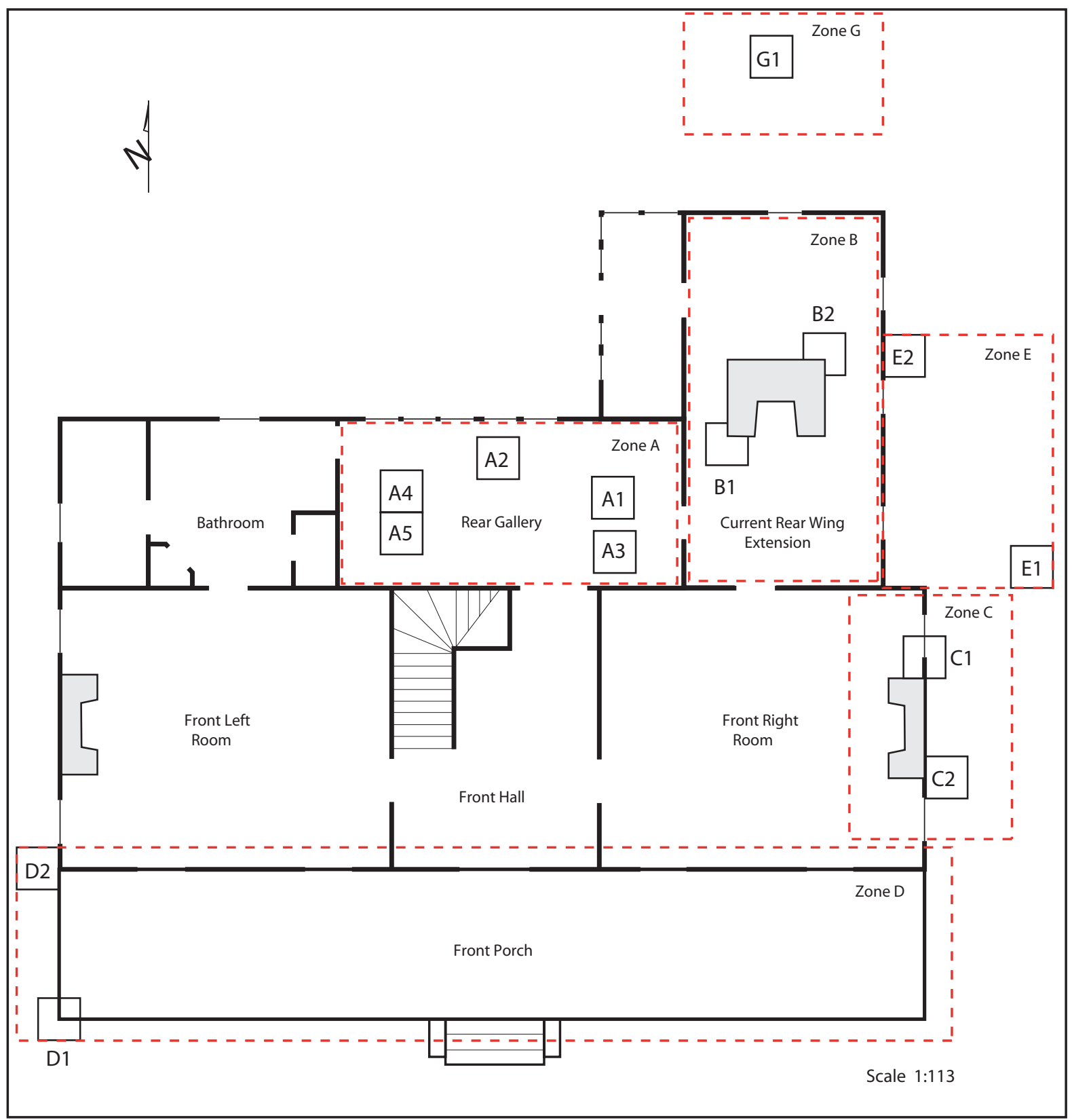

Figure 4-1. Map of the plantation house showing zones and placement of excavation units.

mapped with the aid of a total station. Interior unit locations were recorded based on their distances from interior room walls.

CAS took over 300 photographs using a Kodak digital camera with a zoom lens. Digital photographs were taken of all units, features, and artifacts when appropriate and were recorded on a standardized CAS photo log form in the field. In addition to photographing excavation units and general excavation activities, particular attention was given to archaeological features and artifacts.

\section{Plantation House (Zones A-G)}

A review of the historical documents that mention the main plantation house provides conflicting information on numerous points. 


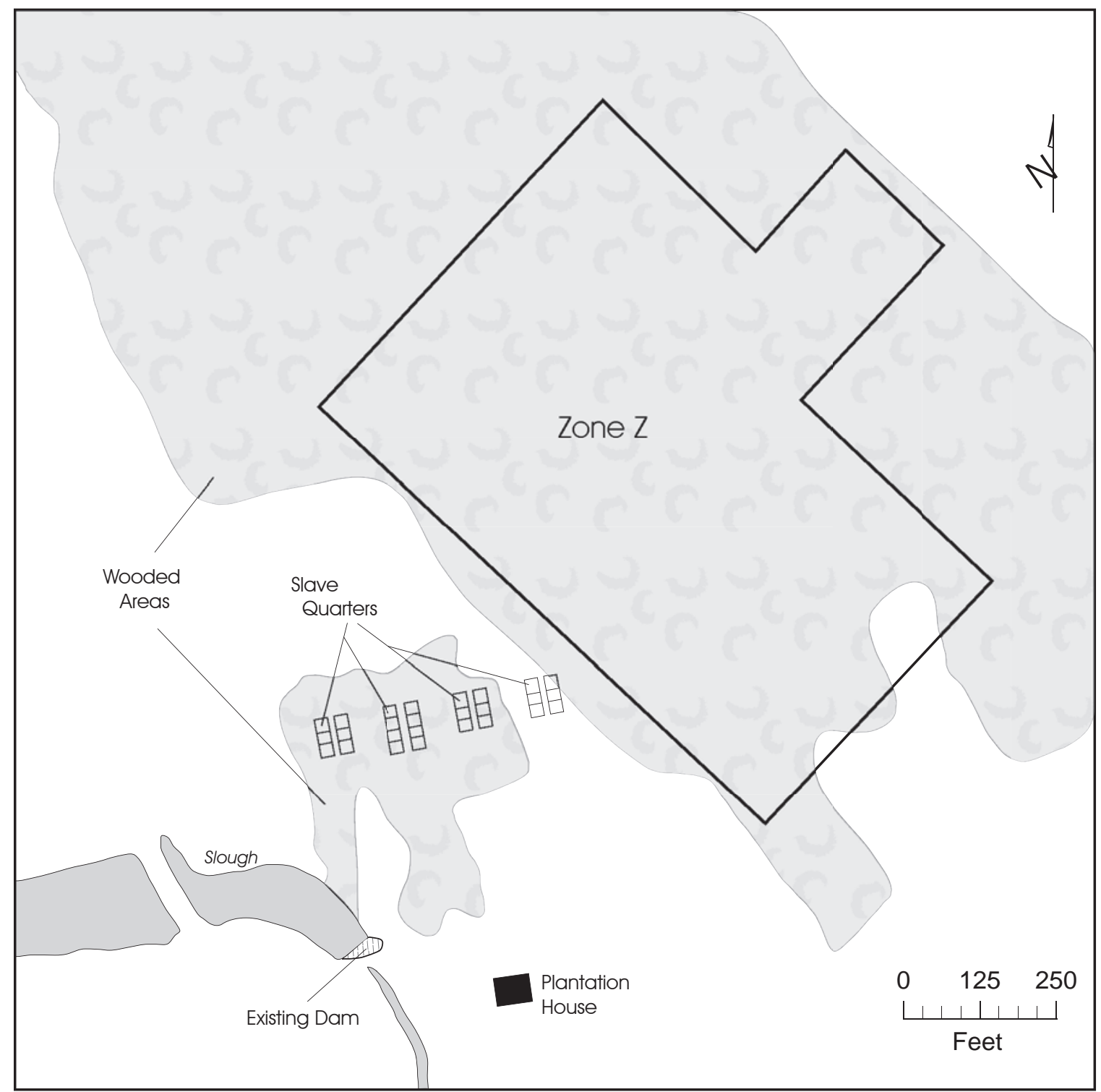

Figure 4-2. Location of Zone $\mathrm{Z}$ in relation to the main plantation house.

The construction sequence of the house, including its initial construction date, how it was constructed, and its original configuration, have yet to be conclusively determined. It is known that the house has undergone modification, but when, why, and what changes were made are unclear. Previous work has been done to identify the numerous visible remains of outbuildings, yet questions exist concerning the location, layout, and function of these remains. CAS investigations tested several hypotheses that have been proposed by TPWD and others.
CAS excavated 14 test units underneath, adjacent to, and near the house. These units were located in Zones A through G (see Figure 4-1) and identified by the zone letter and unit number within that zone (e.g., Unit A1, A2, B1, B2, etc.). Datum points were established for each unit and located in the unit corner containing the highest elevation. Units were excavated to depths varying from 4 to 24 inbd. Archaeological evidence of historical occupations is usually encountered within the first 4-8 inbd of excavations. Therefore, several 
excavations were terminated by the second or third level if it was determined that enough information had been gathered.

Each excavator took detailed notes of their observations. Changes in soil color and texture, feature information, and artifacts encountered were recorded on standardized unit/level forms. When a feature was encountered, an additional feature form was filled out. All soil removed from units was screened through a $1 \frac{1}{4}$-inch wire mesh. Recovered artifacts were collected in paper bags and labeled with their appropriate field provenience information. However, due to the large amount of bricks recovered in these units, it was decided that only a representative sample (less than ten percent) would be taken from each unit level.

\section{Zone A}

Zone A encompasses the gallery room, which is the current rear-center room of the house (see Figure 4-1). When TPWD removed the floorboards of the gallery room, they revealed a fragmentary section of a brick walkway. This walkway is composed of unmortared handmade brick, which suggests an early construction date. The visible remains of the brick walkway suggest that the main exit from the north side of the house descended down steps to the brick walkway. This brick walkway may have originally extended further into the backyard. Brick remains on either side of this brick walkway also point to the possibility that there were additional extensions of the walkway to the east and west.

An interpretation of this area put forth by TPWD is that a rear porch may have been built and attached to the house sometime after the main house's construction. The presence of unused mortises for a porch roof suggests to TPWD that a redesign of the house's rear configuration occurred and may not have been added until a later time. The brick walkway may have been installed as a temporary measure until the porch or wing was built.

To investigate the construction sequence of this area and the extent of visible and nonvisible brick walkways, five units were placed in Zone A (see Figure 4-1). These units were excavated outside the northern door of the house and next to the currently exposed brick walkway. Particular attention was paid to the identification of earlier deposits and/or features relating to possible doorways in the rear of the house and to the walls of the original rear wing to the east of the walkway.

Unit A1 was placed approximately $5 \mathrm{ft}$ north of the southern wall of the gallery room. Excavation Unit A2 was placed in the northcenter of the gallery room, parallel to the north wall, roughly $7.5 \mathrm{ft}$ north of the south wall of the room. This unit lay at the edge of the currently exposed brick walkway. Unit A3 was located about $1 \mathrm{ft}$ south of Unit A1. Units A4 and A5, two adjacent units, were placed in the western portion of the gallery room parallel to the west wall of the room. They were approximately 2.5 $\mathrm{ft}$ from the room's southern wall and about $3 \mathrm{ft}$ from the room's western wall. Units A1, A2, and A3 were excavated to 8 inbd, with the datum established in the southeast corner of each unit at surface level. Units A4 and A5 were terminated at 4 inbd; each datum was set in the southwest corner at surface level.

\section{Zone B}

The current rear wing extension, which extends northward from the east side of the house (see Figure 4-1), is an early twentieth-century addition built to replace the original wing that was damaged by the 1900 Hurricane (Freeman 2003:134). TPWD removed the flooring of 
this room and revealed the foundation of a handmade brick chimney, which they believe was once part of the original wing. Zone B consists of this chimney and the surrounding area. Investigations by TPWD in June of 2004 suggested the chimney had a single hearth that faced southward into the room, toward the house. TPWD hypothesizes that the original north wall of this addition was parallel to the northern edge of the chimney. This would place the fireplace along the north wall of the original wing and not in the center, as it is now located. To test this idea, two units were placed underneath the floorboards at opposing corners of the fireplace foundation (see Figure 4-1). These units were also expected to reveal construction details of the chimney foundation.

Unit B1 was located $1 \mathrm{ft}$ from the east wall of the rear wing extension and approximately $8.5 \mathrm{ft}$ from the south wall. The southwest corner of the chimney foundation intrudes into the northeast corner of Unit B1. The datum for this unit was set at surface level in the southwest corner of the unit. Unit B2 was located at the northeast corner of the chimney foundation $2.5 \mathrm{ft}$ from the east wall of the rear wing room and $8.5 \mathrm{ft}$ from the north wall of the room. The datum was established at surface level in the southeast corner of the unit. Both units were excavated to 16 inbd.

\section{Zone C}

Two identical fireplaces are located along the outer walls of the east and west sides of the main house (see Figure 4-1). The east chimney and surrounding area forms Zone C. TPWD predicts that excavation and comparison of this chimney to the one in Zone B would show that construction details from both chimneys would be identical. This would suggest that construction of both chimneys occurred during the same building phase. Data gathered from these excavations would also provide information concerning construction, weight-bearing strata and the condition of the historic structure. To investigate these possibilities, two units were placed along the northern and eastern sides of the east chimney. These units were located in areas that would minimize disturbance to the stability of the chimney and remaining deposits.

Unit C1 was placed parallel to the north side of the east chimney (see Figure 4-1). The western half of this unit extended underneath the present house structure. Unit C2 was placed parallel to the east wall, on the outside of the main house. Both units were excavated to 16 inbd, with datums established at surface level in the northeast corner of each unit.

\section{Zone D}

Zone D is located in the front porch area (see Figure 4-1). TPWD believes that a wooden porch extended across the full length of the front of the main house in the past. A modern concrete porch, placed on concrete perimeter beams, was added to the front of the house sometime during the mid-twentieth century. This concrete porch was removed by TPWD in 2002. While the width of the original wooden porch is unknown, it is thought to have been similar to the concrete porch. Therefore, the construction of the concrete porch, in addition to any repairs and replacements to the original wooden porch, may have damaged or removed deposits or construction details of the original porch. Furthermore, it is believed that the original porch may have sat on wooden piers. To investigate the location and any remaining construction details of the original porch, including pier locations, two excavation units were located along the western edge of the front porch area (see Figure 4-1). Particular attention was given to the intersection of the house and the porch. 
Unit D1 was located at the southwest corner of the porch, with the porch corner intruding into the unit (see Figure 4-1). Unit D2 was placed parallel to the west wall of the house, at the intersection of the porch and the southwest corner of the house. Datums were established at the surface of the southwest corners. Both units were excavated to a depth of 16 inbd.

\section{Zone $\mathrm{E}$}

This zone was located on the eastern side of the current rear wing extension (see Figure 4-1), and addresses two separate hypotheses. Oral descriptions of test excavations carried out by the University of Houston suggested that a porch of unknown depth and length extended across the eastern side of the main house. In order to confirm this hypothesis, a single test unit was placed in a high probability area (see Figure 4-1). Data gathered from this unit was used to prove or disprove the existence of an eastern porch. The second excavation unit was placed in this location to provide additional data on the location of the east wall of the original rear wing.

Unit E1 was placed approximately $6 \mathrm{ft}$ east of the junction of the original house and the rear wing extension. This unit was excavated to depth of 12 inbd, with the datum set in the northeast corner at the surface. Unit E2 was located approximately $15 \mathrm{ft}$ north of the junction of the original house and the rear wing extension, parallel with the east wall of the current rear wing extension. While the southeast corner was excavated to 24 inbd, the rest of the unit was terminated at 16 inbd. The datum was set in the southeast corner of the unit, at the surface.

\section{Zone G}

Archaeological testing by the University of Houston indicated a possible freestanding kitchen. It is assumed that this detached kitchen served the main house and is located in a mounded area approximately $10 \mathrm{ft}$ north of the current rear wing extension. This area was designated Zone G (see Figure 4-1). In order to locate this feature, a single excavation unit was placed in a high probability location within Zone G (see Figure 4-1).

Unit G1 was placed roughly $9.5 \mathrm{ft}$ north of the centerline of the north wall of the rear wing extension. The datum was established in the southwest corner of the house at surface level. It was excavated to a depth of 24 inbd.

\section{Visitor Area (Zone Z)}

TPWD has proposed an area located northeast of the main house for the development of a visitor center and maintenance yard (see Figure 4-2). This area, Zone Z, covers 15.32 acres and measures $1000 \times 630 \mathrm{ft}$, with an additional $100 \times 220 \mathrm{ft}$ to be included for an access road. CAS conducted a pedestrian survey and placed 36 shovel tests in this area to test for the location of possible plantation outbuildings and other historic features (Figure 4-3). The dense foliage of the area and the presence of poison ivy greatly affected the evaluation process. While every attempt was made to maintain the transect lines established for the survey and shovel tests, this was not always possible. In instances where dense foliage and/or poison ivy prevented placement of a shovel test, the test was relocated to an area as close as possible to the transect point.

\section{Pedestrian Survey}

To conduct a systematic pedestrian survey, transect lines were established about $100 \mathrm{ft}$ apart on a rough north-south grid across Zone $\mathrm{Z}$ (see Figure 4-3). These transect lines originated approximately $100 \mathrm{ft}$ northeast of the Dow rightof-way and proceeded in a west-east direction throughout Zone Z. CAS archaeologists walked 


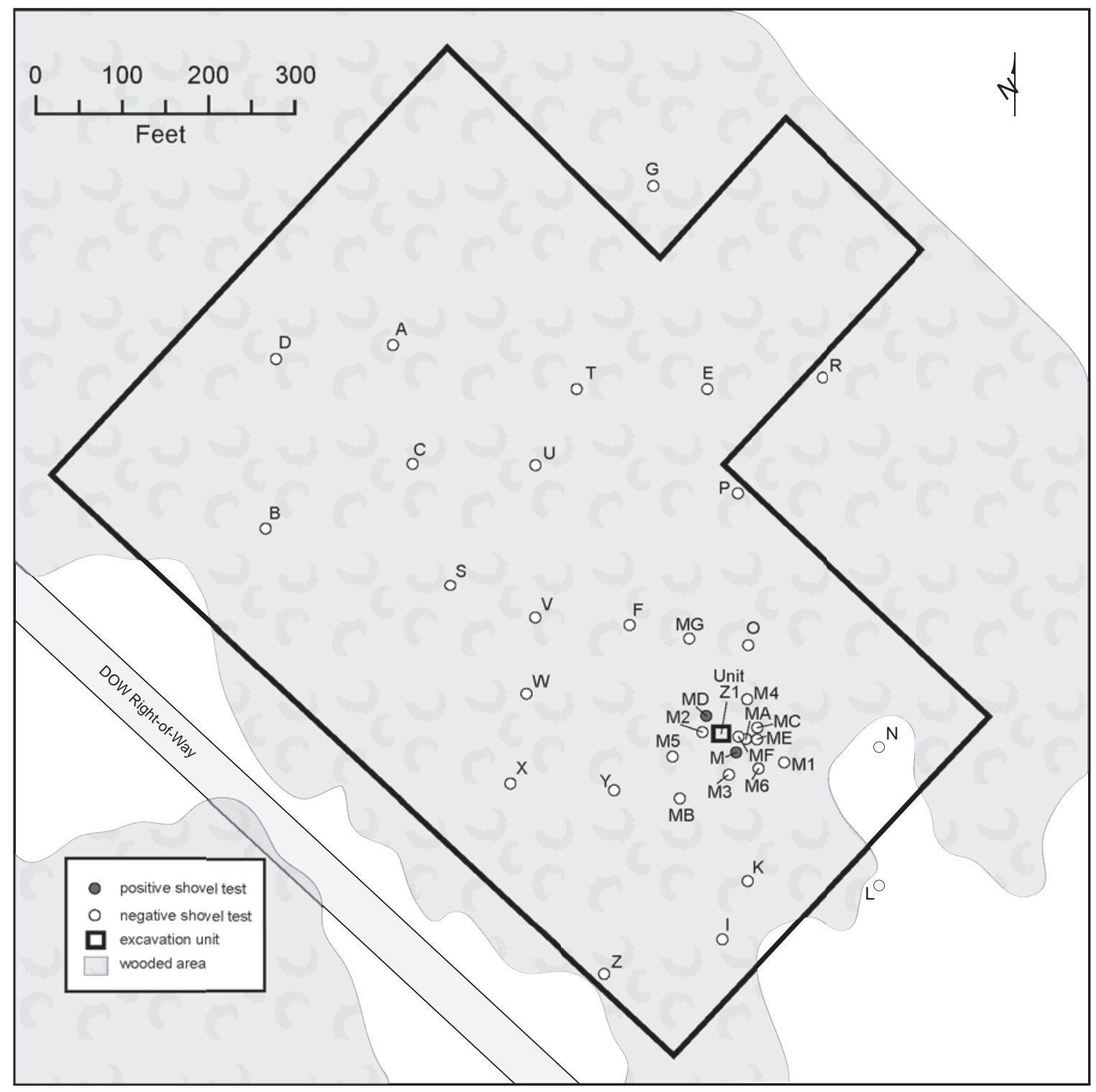

Figure 4-3. Map of Zone Z showing locations of shovel tests and Unit Z1.

these transect lines and examined the surface for any visible features and/or artifacts.

\section{Shovel Tests}

The transect established for the pedestrian survey was used simultaneously for the shovel test transect. Shovel tests were located approximately 130-160 ft apart, depending upon flora and foliage limitations (see Figure 4-3). A shovel test was defined as a $1 \mathrm{x} 1-\mathrm{ft}$ unit excavated in 4-inch intervals to a depth of 20 inches below surface. Soil was screened through a $1 / 4$-inch wire mesh. Shovel tests (STs) were labeled alphabetically (e.g., STA, STB, etc.). Shovel tests excavated to delineate a possible site were labeled with double letters or a letter and a number, depending on their location to the original positive shovel test; those with a letter and number were located approximately 16-22 $\mathrm{ft}$ away, while those with double lettered units were located approximately $50 \mathrm{ft}$ away (e.g., STM2 and STMD, respectively). Locations of shovel tests were recorded using Global Positioning System (GPS) units. Artifacts 
and soils encountered during excavation were recorded on a standardized shovel test form. Collected artifacts were placed in bags labeled with their appropriate field provenience. The total number of shovel tests excavated, 36, either met or exceeded the minimum survey standards issued for survey areas of 200 acres or less established by the Texas Historical Commission (THC).

\section{Excavation}

Based on the results of the shovel tests (discussed in Chapter 5), Unit Z1 was placed in the southern portion of Zone $\mathrm{Z}$, between STM and STMD (see Figure 4-3). A datum was established in the southwest corner of the unit at surface level. The unit was excavated to a depth of 12 inbd.

\section{Laboratory Methods}

A temporary field laboratory was established in West Columbia, Texas, where artifacts and forms were accounted for daily. Upon return to San Marcos, cultural materials were inventoried at the CAS laboratory. All artifacts recovered during the investigations at the Levi Jordan Plantation were processed in accordance with the Archeology Lab Manual (TPWD 1995). Lot numbers were assigned to artifacts in the lab. CAR laboratory staff washed the artifacts, sorted them within lots by general artifact types, and allowed them to dry. Lab staff members then cataloged the collection, entered the information into a database, and labeled appropriate artifacts. Catalogue numbers were created using the provenience information and a code to indicate the artifact classification. Analysis was conducted and results entered into the database. Following this stage, artifacts were placed in temporary curation.

At the CAS lab, all cultural materials collected were prepared for storage in accordance with federal regulation 36 CFR 79, current guidelines of the Council of Texas Archeologists, and with the Texas Archeological Research Laboratory. Artifacts processed in the CAS laboratory were stored in archival-quality bags, with acid-free labels placed in all bags. Glass, ceramics, and other non-porous artifacts larger than a quarter were given a coat of PVA, labeled with permanent ink, and covered by a second coat of PVA. Following a quality control check, all artifacts were prepared for permanent storage. They were sorted into general artifact type bags, labeled with provenience and type information, and stored in acid-free boxes with standard labels.

All excavation forms, maps, drawings, photographs, computer disks, and field records, along with a copy of this report on acid-free paper, were submitted to TPWD. Preliminary analysis data derived in the lab was also submitted to TPWD. Maps containing the precise plotting of each excavation and shovel test unit on TPWDbase maps suitable for input to the TPWD GIS database were also presented upon completion of the Levi Jordan Plantation Project. 


\section{Chapter 5}

\section{RESUlts}

Archaeological investigations at the Levi Jordan Plantation began with a pedestrian survey, the excavation of 36 shovel tests, and a single test unit within Zone $\mathrm{Z}$, the area proposed for visitor center development. This was followed by the excavation of 14 test units in Zones A through G underneath or next to the main plantation house. Shovel tests measured $1 \mathrm{x} 1 \mathrm{ft}$ and all test units were 3x3 ft. Levels were measured in 4-inch intervals and depths recorded in inches below datum (inbd). Data gathered from these excavations addressed questions and hypothesis postulated by TPWD. Eight features were excavated and over 9,000 artifacts recovered including glass, ceramics, metal, bricks, and various personal items. Chapter 6 will present a detailed analysis of artifacts collected during excavations.

\section{Plantation House (Zones A-G)}

A total of eight features were uncovered through the excavation of 14 units within the five differing zones within or near the main plantation house (see Figure 4-1). Data collected from these excavations and features were used to address hypotheses and questions postulated by TPWD concerning the layout and construction of the house. Recovered artifacts such as brick, ceramic, metal, glass, and organic materials also aided in addressing these questions, in addition to providing insight to the socioeconomic status of the occupants during the antebellum period.

\section{Zone A}

Earlier investigations have revealed that the rear gallery room was constructed over a section of brick walkway. To determine the extent of the brick walkway and explore the construction sequence of a possible porch, five units were excavated in this zone.

Initial examination of Unit A1 at the surface revealed a series of handmade bricks in the western half of the unit that formed the edge and body of a brick walkway (Figure 5-1). Whole bricks or large brick fragments that were part of a defined edge or walkway were numbered on the level plan view and collected separately.

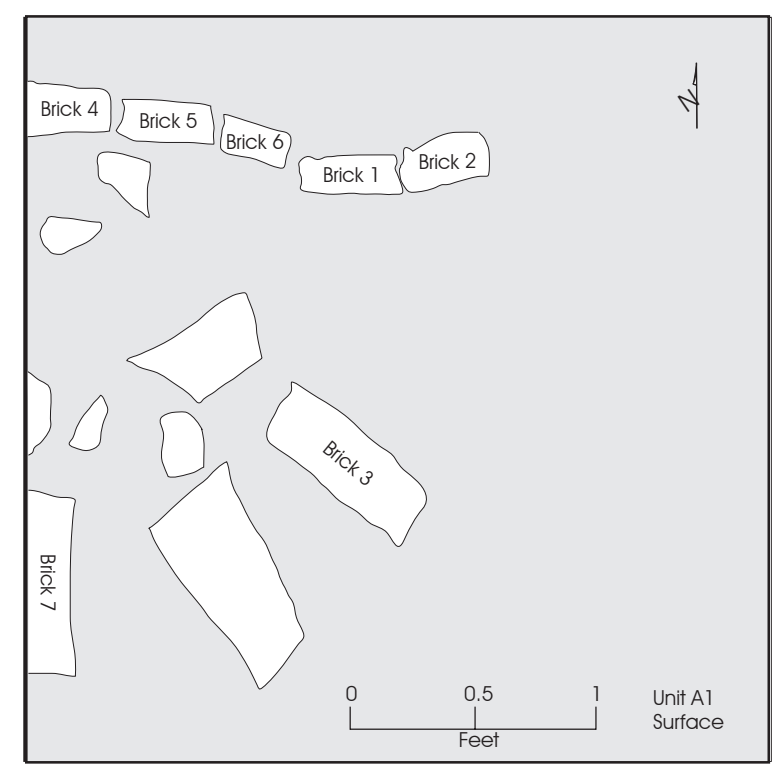

Figure 5-1. Illustration of the surface of Unit A1 showing numbered bricks. 


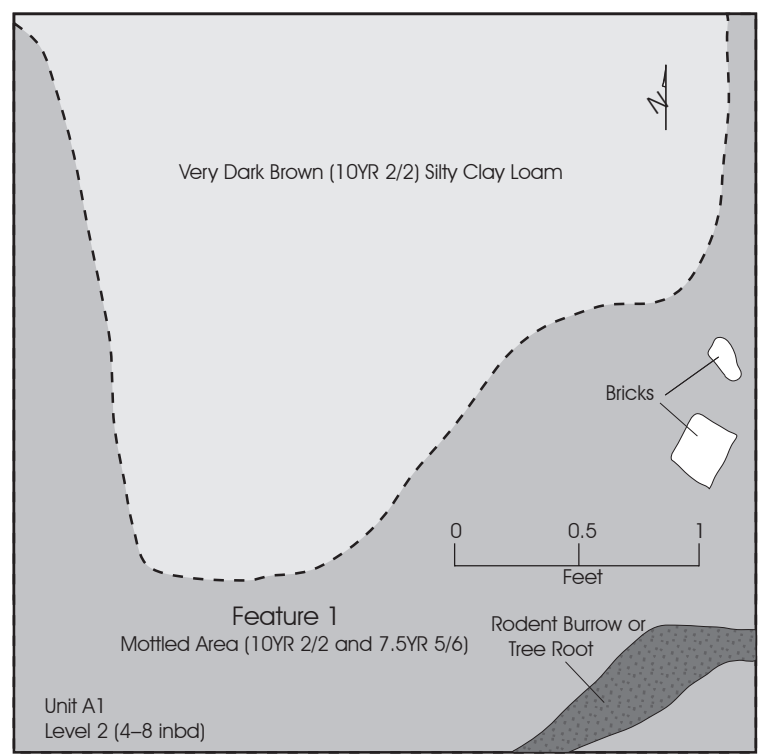

Figure 5-2. Illustration of Unit A1 level 2 (4-8 inbd) showing Feature 1.

At 6 inbd, a change in soil color became apparent and was designated Feature 1 (Figure 5-2). Feature 1 extended diagonally through the unit, from the southwest to northeast corner. The soil was a very dark brown, silty clay loam similar to that of the rest of the unit, except that it was mottled with a strong brown silty clay loam. This soil color suggested that a brick walkway was once located above it. Excavation of both Feature 1 and the unit was terminated at 8 inbd, at which point sterile soil was encountered. Artifacts recovered from this unit are listed in Table 5-1. The majority of artifacts were representative of construction activity, with more than five pounds of handmade and glazed brick (excluding numbered bricks) collected, along with $1 / 3 \mathrm{lb}$ of mortar, nearly one pound of nails, over one pound of metal, and window glass. However, domestic activities were also represented by artifacts such as animal bone, a German ceramic marble, decorated ceramics, doll/figurine fragments, bottle glass, chimney and light bulb glass, a spoon, an 1883 Liberty Head nickel, buttons, yarn, several chalkboard fragments, and fragments of a metal vessel were recovered.
Unit A2 also contained a line of handmade bricks. This line extended in a diagonal direction from the southeast corner to the northwest corner of the unit (Figure 5-3). These bricks too were numbered and collected individually. When the soil color and matrix underneath the brick was compared with Feature 1 in Unit A1, it was determined that they were one continuous feature, and therefore it was not given a different feature number. This soil was also of a very dark brown silty clay loam mottled with strong brown silty clay loam. Excavations were terminated at 8 inbd, at which point dark Houston Black clay, the characteristic sterile foundation soil of the region, was encountered. Table 5-1 presents a summary of artifacts collected from this unit. This unit also contained large amounts of brick (nearly ten pounds), and mortar (two pounds), with smaller amounts of nails and window glass present. Also found was bone, a doll's arm, porcelain teacup handle, bottle and chimney glass, decorated tableware glass, a thermometer, munitions, another chalkboard fragment, leather, paper, a toy face, a handle, and a black satin bow.

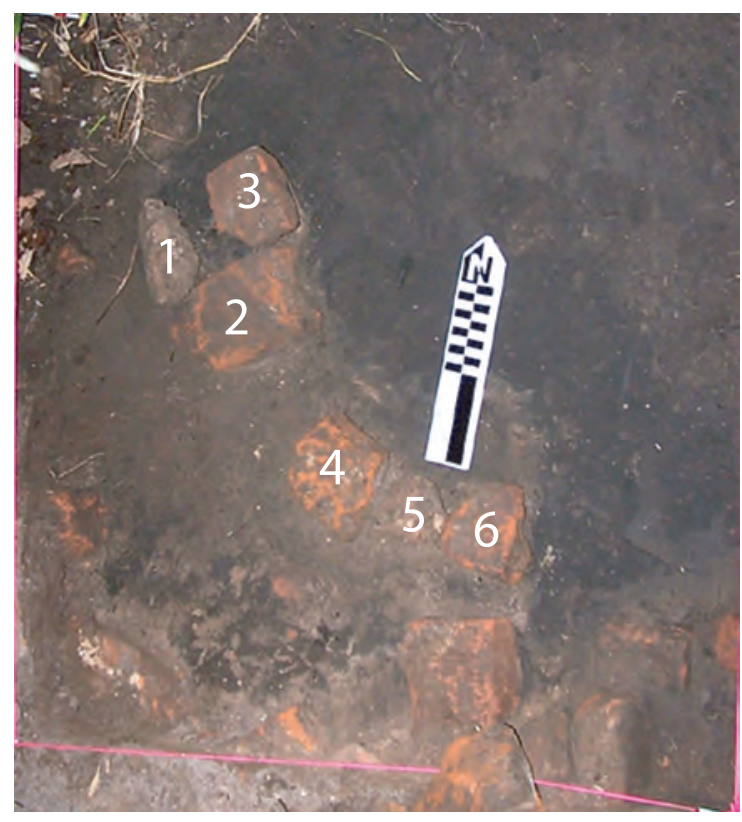

Figure 5-3. Photograph of Unit A2 level 1 (0-4 inbd) showing numbered bricks, facing north. 


\begin{tabular}{|c|c|c|c|c|c|c|c|c|c|c|c|c|c|c|c|c|c|c|c|c|c|c|c|c|c|}
\hline S[Е]०L & $\begin{array}{l}0 \\
6 \\
6\end{array}$ & $\stackrel{n}{m}$ & 㡫 & $\stackrel{2}{\sim}$ & भ & $\begin{array}{l}\mathscr{D} \\
\stackrel{\tilde{J}}{\exists}\end{array}$ & 守 & $\left|\begin{array}{l}0 \\
0 \\
ల\end{array}\right|$ & $\stackrel{m}{\infty}$ & 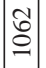 & 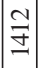 & 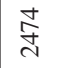 & 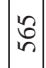 & 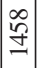 & ָָ & & $\begin{array}{l}0 \\
0 \\
0\end{array}$ & $\begin{array}{l}\text { Dे } \\
\text { ลे }\end{array}$ & $\mid \begin{array}{c}0 \\
\stackrel{\infty}{-}\end{array}$ & $\stackrel{\widehat{O}}{\stackrel{f}{\prime}}$ & $\stackrel{ㄴ}{N}$ & in & -1 & $\infty$ & $\begin{array}{l}\mathscr{D} \\
\mathscr{D}\end{array}$ \\
\hline иләроџ & $\sim$ & -1 & 0 & 0 & 0 & $m$ & 0 & 0 & 0 & -1 & 0 & 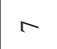 & 0 & $\infty$ & $\Xi$ & -1 & 0 & -1 & -1 & - & 0 & 0 & 0 & 0 & $\stackrel{2}{2}$ \\
\hline ગ!рәцди SS $_{\mathrm{S}}$ & 0 & 0 & 0 & 0 & 0 & 0 & -1 & 0 & -1 & 2 & 0 & $\sim$ & 0 & $m$ & $m$ & 0 & 0 & 0 & 0 & 0 & 0 & 0 & 0 & 0 & 0 \\
\hline ІІә્પS & $\rightarrow$ & 의 & $\nabla$ & 0 & 0 & $\hat{\imath}$ & -1 & a & 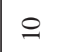 & $\exists$ & $\approx$ & 商 & $m$ & $\infty$ & $\exists$ & $F$ & $F$ & $\infty$ & 9 & $\stackrel{9}{7}$ & 0 & 0 & - & 0 & $\underset{\mathscr{A}}{\mathscr{m}}$ \\
\hline әІ!ХХІ & $\nabla$ & -1 & $m$ & 0 & 0 & $\infty$ & $N$ & -1 & $m$ & -1 & -1 & $\sim$ & $m$ & N & L & 0 & -1 & -1 & 0 & 0 & 0 & 0 & 0 & 0 & 9 \\
\hline səqqny & N & 0 & 0 & 0 & 0 & N & 0 & 0 & 0 & 0 & 0 & 0 & 0 & -1 & -1 & 0 & 0 & 0 & 0 & 0 & 0 & 0 & 0 & 0 & $m$ \\
\hline ग!̣seId & N & 0 & $m$ & 0 & 0 & م & $\sim$ & 0 & $\infty$ & $\nabla$ & a & $\ddot{m}$ & $\wedge$ & $a$ & $\mathscr{1}$ & $\sim$ & $\sim$ & $\nabla$ & a & $\sigma$ & 0 & 0 & 0 & 0 & 造 \\
\hline sயəłI ¡Euos.ıəd & $\nabla$ & $m$ & in & 0 & 0 & $\simeq$ & -1 & -1 & $\sim$ & 0 & -1 & 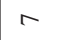 & $m$ & $\nabla$ & $\wedge$ & $\nabla$ & $m$ & $\wedge$ & $m$ & $m$ & 0 & 0 & 0 & 0 & $\infty$ \\
\hline गฺ̣ుะฉి. & in & 0 & $\sim$ & 0 & 0 & $\mathscr{m}$ & $\sim$ & 0 & $\sim$ & $\nabla$ & 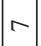 & $\exists$ & -1 & $\sim$ & $m$ & $m$ & $m$ & 0 & 0 & 0 & 0 & 0 & 0 & 0 & L \\
\hline 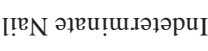 & $\infty$ & \pm & in & 0 & -1 & 록 & $\vec{m}$ & เัต & เீ & $\stackrel{\infty}{-}$ & সে & $\widetilde{6}$ & $\vec{m}$ & 응 & $\stackrel{\infty}{m}$ & 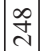 & 늉 & ల్ల & n & in & 0 & 0 & 0 & 0 & 는 \\
\hline I!̣eN ə.enbs & - & 0 & 0 & 0 & 0 & $\wedge$ & -1 & $m$ & $\forall$ & $\approx$ & $\stackrel{\Delta}{ }$ & $\ddot{m}$ & 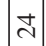 & ิ & J & 슨 & $\mid \vec{m}$ & $\infty$ & a & $a$ & 0 & 0 & 0 & o & $\mid \begin{array}{l}\infty \\
\infty \\
\mathbb{=}\end{array}$ \\
\hline I!̣N punoy & $\exists$ & $\tilde{\vartheta}$ & J & 0 & -1 & $\infty$ & $\bar{\lambda}$ & $\sim$ & ขิ & $F$ & $\infty$ & $\stackrel{\mathscr{ユ}}{\simeq}$ & $\tilde{m}$ & 8 & 흑 & त & 늑 & 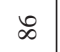 & in & เ & 0 & 0 & 인 & 0 & $\tilde{\overparen{\vartheta}}$ \\
\hline suo!̣!̣unW & 0 & -1 & $\nabla$ & 0 & 0 & م & 0 & 0 & o & 0 & $n$ & $m$ & $\sim$ & $\wedge$ & $a$ & 0 & $N$ & $\stackrel{\infty}{-}$ & 0 & 0 & 0 & o & 0 & 0 & L \\
\hline [ЕұәИ Аәч૧О & $\stackrel{\infty}{*}$ & $\stackrel{m}{\rightarrow}$ & ल & 0 & $\wedge$ & ลิ & 놋 & ลิ & 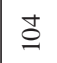 & 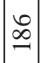 & $\hat{\beth}$ & $\vec{m}$ & $\bar{\imath}$ & $\exists$ & $\stackrel{\nu}{m}$ & $\left|\begin{array}{l}\text { L } \\
\text { 足 }\end{array}\right|$ & 8 & 㤐 & $\sim$ & $\sim$ & 0 & 0 & 0 & 0 & 点 \\
\hline ІејәW & $m$ & $\nabla$ & is & 0 & $\sim$ & $\unlhd$ & 0 & $m$ & $\sigma$ & $\wedge$ & 윽 & $\approx$ & a & $F$ & ถి & $\infty$ & $\stackrel{2}{2}$ & $\stackrel{2}{\circ}$ & $\sim$ & $\sim$ & 0 & 0 & 0 & 0 & Оิ \\
\hline ग!Ч॥!Т & $\sim$ & $\sim$ & 0 & 0 & 0 & $\nabla$ & $\infty$ & $m$ & $\exists$ & 0 & $m$ & $m$ & 0 & -1 & $\wedge$ & -1 & $\infty$ & 0 & -1 & - & 0 & 0 & 0 & 0 & $\approx$ \\
\hline ІәццеәТ & 0 & -1 & 0 & 0 & 0 & -1 & 0 & 0 & o & 0 & 0 & $\circ$ & 0 & 0 & 0 & 0 & 0 & 0 & 0 & 0 & 0 & 0 & 0 & 0 & -1 \\
\hline 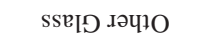 & 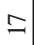 & $m$ & $m$ & in & 0 & $\stackrel{\infty}{\sim}$ & $\sim$ & $\sim$ & $\forall$ & $\bar{\lambda}$ & ำ & $F$ & -1 & 0 & $\wedge$ & 足 & $\underline{-1}$ & กิ & -1 & -1 & 0 & 0 & $\circ$ & o & $\tilde{m}$ \\
\hline 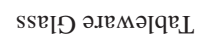 & 0 & $m$ & 0 & + & 0 & $\wedge$ & -1 & 0 & - & 으 & $\wedge$ & $\asymp$ & $m$ & $\nabla$ & $\wedge$ & $m$ & $\sim$ & $\stackrel{2}{\sim}$ & 0 & $\circ$ & 0 & 0 & 0 & o & F \\
\hline sse「つ Кәиш!ฺつ & $\nabla$ & $\approx$ & -1 & $\sigma$ & 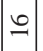 & กิ & เ & $m$ & $\infty$ & a & タ & ถึ & $\nabla$ & $\approx$ & $\stackrel{\varphi}{-1}$ & ले & 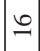 & 㶽 & $\sim$ & $\sim$ & $\sim$ & 0 & 0 & $\sim$ & $\mid \begin{array}{l}\infty \\
\infty \\
\stackrel{-1}{*}\end{array}$ \\
\hline 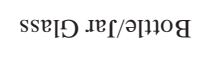 & $\stackrel{4}{A}$ & $\approx$ & is & N & $\wedge$ & 으 & 의 & $\because$ & ลิ & $\bar{m}$ & $\bullet$ & के & $\overrightarrow{6}$ & $\stackrel{\mathscr{\sim}}{-}$ & $\underset{\sim}{+\infty}$ & 胥 & 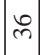 & $\stackrel{n}{\simeq}$ & $\nabla$ & $\nabla$ & 0 & 0 & 0 & 0 & $\mid$ \\
\hline sse[כ морш!м & 它 & $\stackrel{\sim}{\sim}$ & 년 & in & $\nabla$ & $\underset{\sim}{\infty}$ & $\infty$ & 읔 & $\stackrel{\infty}{\stackrel{9}{I}}$ & 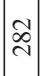 & $\begin{array}{l}\infty \\
0 \\
0\end{array}$ & ஜి & సి & 竞 & ఫ̊ & న్ & సి & $\stackrel{\Re}{\sigma}$ & 0 & 0 & -1 & 0 & 0 & -1 & 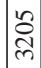 \\
\hline ग!ฺய.лวכ & 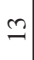 & $\nabla$ & 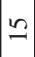 & 0 & 0 & ஸे & $m$ & $\infty$ & $\exists$ & 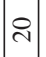 & 6 & $\infty$ & 씨 & ஓ & $\stackrel{\Xi}{ \pm}$ & 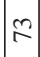 & 吕 & 욱 & -1 & $\neg$ & 0 & 0 & - & 0 & 志 \\
\hline әиоя & $m$ & $\stackrel{2}{\sim}$ & a & 0 & $\diamond$ & $\exists$ & $\approx$ & $\rightarrow$ & ูํ & $\stackrel{\circ}{0}$ & $\vec{m}$ & $\stackrel{\mathscr{m}}{\mathrm{m}}$ & $\stackrel{2}{2}$ & $\approx$ & f & $\hat{\theta}$ & ล & $\infty$ & -1 & $\neg$ & 0 & 0 & 0 & o & $\frac{7}{7}$ \\
\hline צગ!ı рәzе|ગ & $\mathrm{N}$ & 0 & 0 & 0 & 0 & $\sim$ & 0 & - & - & $\checkmark$ & -1 & เ & 0 & $\sim$ & $\sim$ & -1 & $\infty$ & 0 & 0 & 0 & \llcorner & $\stackrel{2}{N}$ & -1 & $\vec{m}$ & $\tilde{น}$ \\
\hline צગા.. & $\mathscr{~}$ & 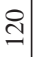 & $\stackrel{\infty}{\sim}$ & 0 & $m$ & $\widehat{\hat{\vartheta}}$ & 学 & $\sigma$ & $\widetilde{\widetilde{N}}$ & $\widehat{\widehat{A}}$ & 9 & $\stackrel{D}{\sim}$ & 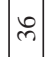 & $\infty$ & $\stackrel{\infty}{=}$ & $\stackrel{0}{2}$ & $\mid$ & $\exists$ & बे & চ & $\wedge$ & $\bar{m}$ & 0 & $\stackrel{\infty}{\infty}$ & 同 \\
\hline 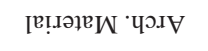 & $\hat{m}$ & ร & ช & 0 & $\sim$ & 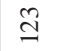 & $\stackrel{\circ}{\infty}$ & q & $\stackrel{\infty}{\simeq}$ & 속 & ڤ્ & $\overparen{ֶ}$ & $\exists$ & m & 우 & $\vec{\sim}$ & $\stackrel{\vartheta}{N}$ & f & 0 & $\stackrel{0}{0}$ & $\nabla$ & 0 & 0 & $\nabla$ & $\overrightarrow{\tilde{\vartheta}}$ \\
\hline $1 ! \mathrm{U}_{\Omega}$ & $\bar{\varangle}$ & $\underset{4}{\pi}$ & $\stackrel{m}{\&}$ & 思 & 这 & 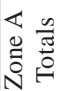 & $\bar{n}$ & $\tilde{\infty}$ & 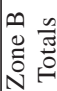 & تี & ปี & 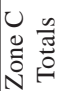 & $\vec{\theta}$ & $\tilde{A}$ & 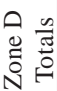 & 되 & 괴 & 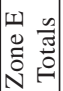 & 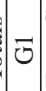 & 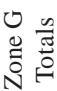 & $\vec{N}$ & $\mid$ & 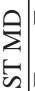 & 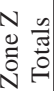 & 章 \\
\hline
\end{tabular}


While Unit A3 lies one foot south of Unit A1, it did not contain any indications of Feature 1. No soil color changes or large quantities of brick to suggest a brick walkway were encountered, and the unit was terminated at 8 inbd. The first level of this unit contained more artifacts than those recovered from the first levels of the previous two units. Over 2.5 lbs of brick, $1+\mathrm{lb}$ of concrete, over 100 nails, and window glass were recovered from this unit. Several pieces of broken and discarded ceramics were recovered from this unit. Most of these ceramics have been identified with manufacture dates established between 1850 and 1895 (see Chapter 6 for a more detailed discussion of these artifacts). Animal bone, bottle and chimney glass, kitchenware glass, metal, munitions, buttons, combs, shell, and yarn was found (see Table 5-1).

Units A4 and A5 were placed at in the western end of the gallery room. Both units were excavated to depth of 4 inbd, at which point a layer of hard, crushed brick mixed with caliché was encountered and excavations ended (Figure 5-4). Very few artifacts were recovered from these units, the majority of which were glass fragments (see Table 5-1). Unit A4 contained only glass, while Unit A5 yielded brick, mortar, bone, bottle and chimney glass, window glass, and hardware. A5 also contained a piece of

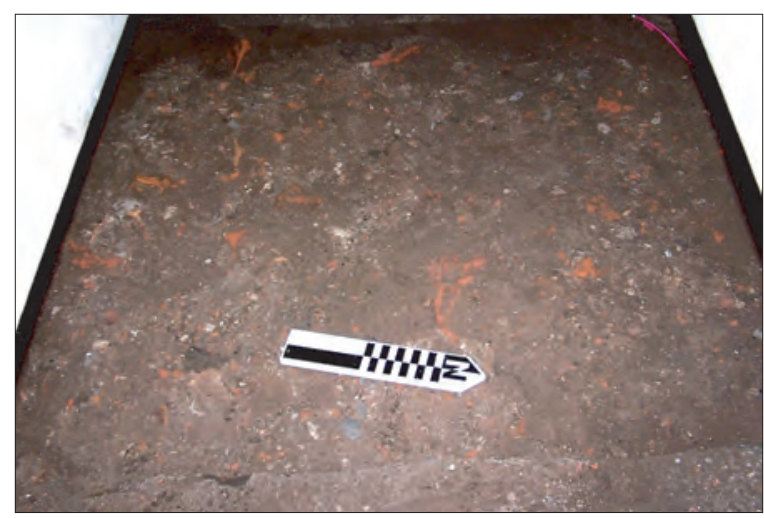

Figure 5-4. Photograph of Unit A5 level 1 (0-4 inbd) showing brick caliché terrace, facing west. chimney glass that refits with one from Unit A2 and resembles those manufactured by the Phoenix Glass Company in 1897.

\section{Zone B}

Excavation units were placed on opposing corners of the fireplace foundation that was located under the floorboards of the current rear wing. These units provided data on the location of the possible outer wall of the original rear wing. Data on the construction of this handmade brick chimney were also gathered and compared with that collected during excavations within Zone C.

Unit B1, located on the southwest corner of the fireplace foundation, was excavated to a depth of 16 inbd. At a depth of 4 inbd, Feature 2 , a construction trenched filled with a matrix of a brown silty loam with specks of black clay, was encountered next to the step-out brick base of the chimney foundation (Figure 5-5). This feature continued through to the last excavation level at 16 inbd, and continued to be found in association with the brick step-outs. A course of four brick step-outs in total were uncovered in this unit (Figure 5-6). A small 12x6-inch exploratory column within Feature 2 was

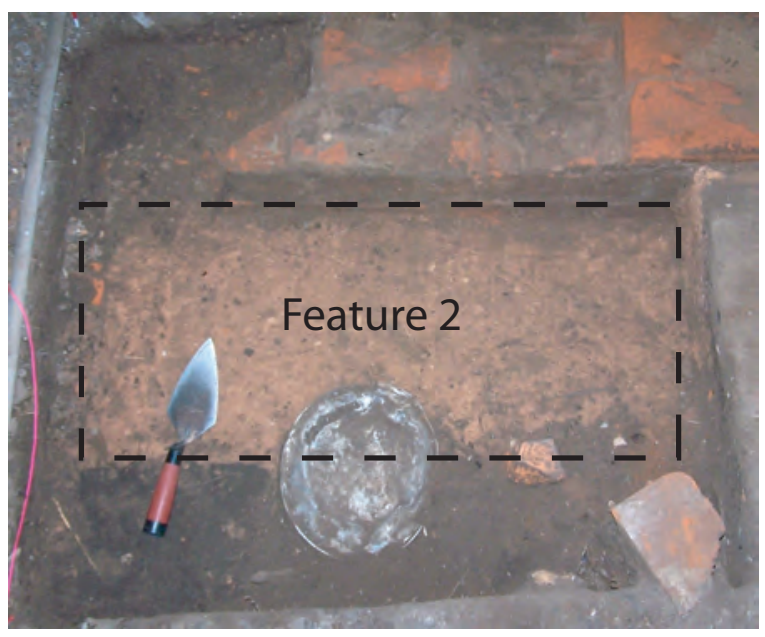

Figure 5-5. Photograph of Unit B1 level 1 (0-4 inbd) showing Feature 2, facing north. 


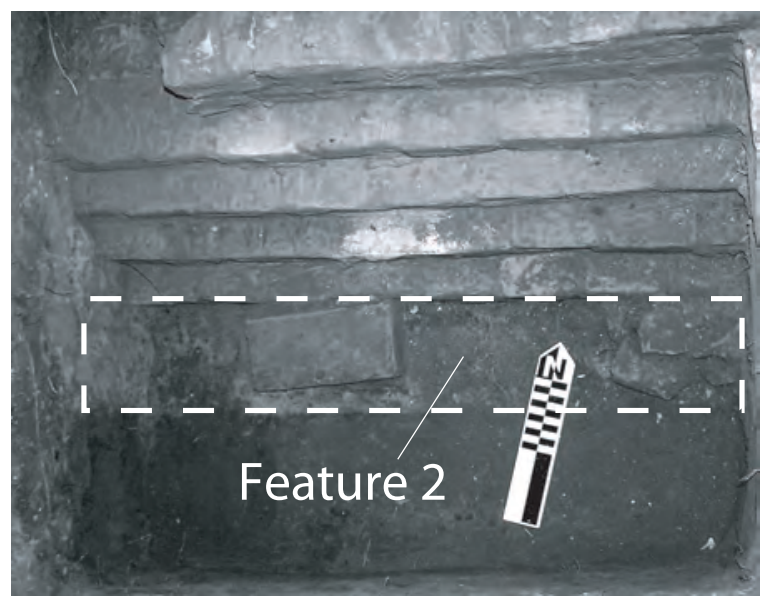

Figure 5-6. Photograph of Unit B1 level 4 (12-16 inbd) showing Feature 2 and brick step-outs, facing north.

further excavated to a depth of 18 inbd in order to expose the bottom of the chimney foundation step-outs and the bottom of the construction pit matrix (Figure 5-7). Excavation ceased when dark Houston Black Clay was encountered.

All brickstep-outs were left in situ to preserve the structure of the chimney. The majority of artifacts recovered from this unit consisted of bricks and brick fragments (five pounds of which was collected); in addition, two pounds of mortar and 50 nails were collected. Half of the nails were identified as round nails. A sizable amount of window glass was also collected from Unit B1 with a preponderance dated to the mid-1800s (see Chapter 6 for a discussion on window glass dating). Further recovered artifacts include animal bone, ceramics, bottle and chimney glass, an aluminum pie plate, hardware, indeterminate metal fragments, a bracelet, and cloth fibers (see Table 5-1).

Unit B2 was located in the northeast corner of the fireplace foundation (see Figure 4-1). This unit was excavated to a depth of 16 inbd. At a depth of 4 inbd, a filled construction trenched was encountered, but was not as well defined as the one in Unit B1. This feature was not labeled.
Of note is a soil color change, first encountered at a depth of approximately 6 inbd. The northern half of the excavation unit was characterized by a very dark brown, silty clay loam while the southern half, containing the chimney foundation, step-outs, and construction trench, was a lighter, mottled brown soil. A course of five brick step-outs was uncovered in this unit. Within Unit B2, a 10x6-inch exploratory column next to the last course of brick step-outs was further excavated to 18 inbd. This column exposed the bottom of the chimney foundation and the bottom of construction pit (Figure 5-8). The chimney foundation terminated at approximately 16.5 inbd, while the construction trench terminated approximately 17.5 inbd.

Again, all bricks that composed the chimney foundation and its step-outs were left in placed and not removed. A total of six pounds of loose, whole bricks or brick fragments were recovered, in addition to slightly less than one pound of mortar. Approximately 1/3 lb of window glass, with several groupings dating to the mid- to late 1800s, was recovered from Unit B2. This unit also contained a large quantity of metal artifacts

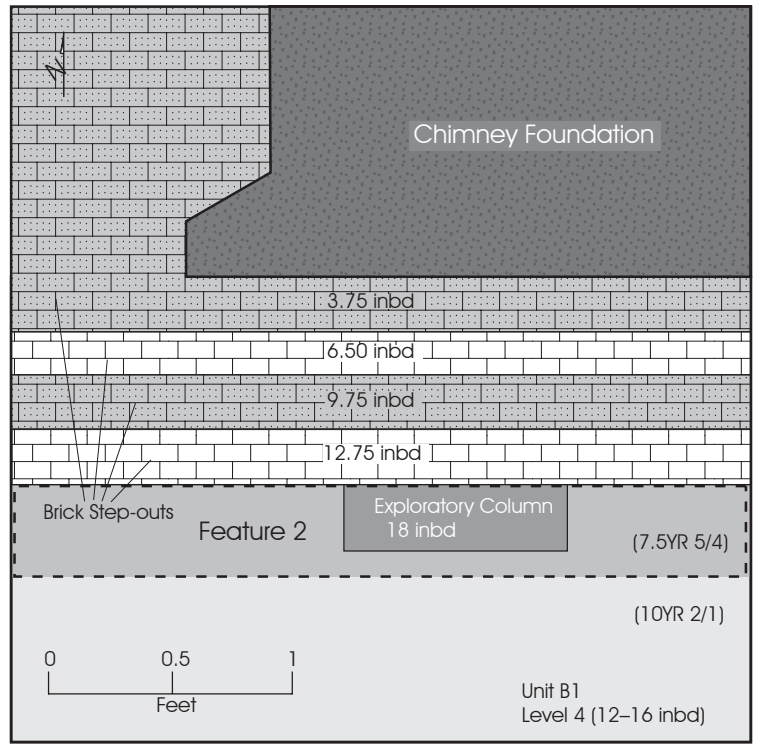

Figure 5-7. Illustration of Unit B1 level 4 (12-16 inbd) showing Feature 2 and the exploratory column. 


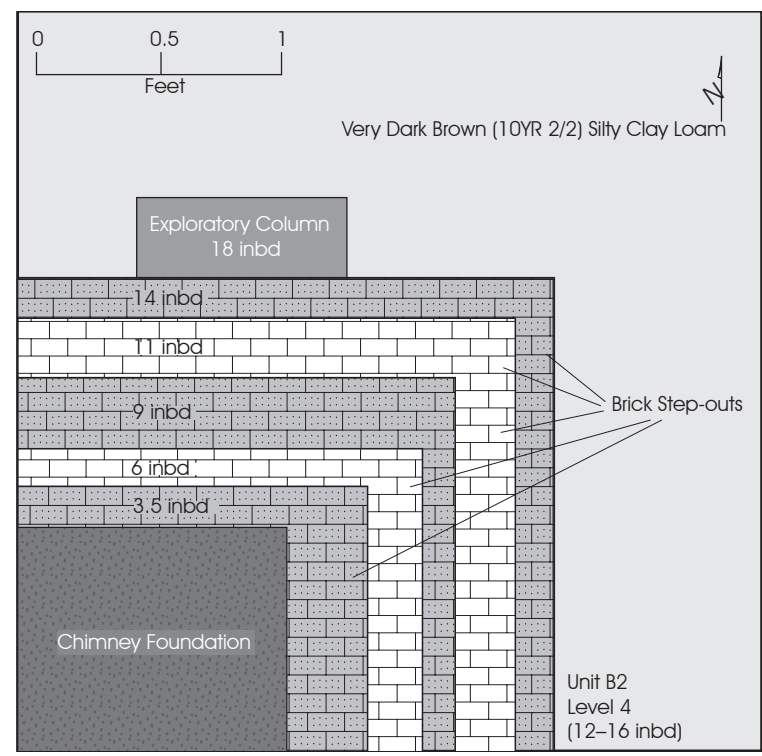

Figure 5-8. Illustration of Unit B2 level 4 (12-16 inbd) showing the exploratory column and the brick step-outs.

$\left(\begin{array}{ll}1 / 2 & \mathrm{lb}\end{array}\right)$. Additional collected artifacts included glass bottle fragments, a glass mason jar lid liner, lamp chimney glass, cloth fibers, oyster and scallop shell, and a plastic button (see Table 5-1). A piece of a large fiestaware bowl rim and a fragment of a blue decal-decorated English white earthenware vessel are representative of the ceramic artifacts collected.

\section{Zone C}

Excavations conducted in Zone $\mathrm{C}$ focused on the east chimney of the main house. Units were placed on opposing corners of the chimney, to expose its foundation. Results were compared with those from Zone B.

Unit C1 was excavated to a depth of 16 inbd. As in the construction trenches uncovered in Units B1 and B2, a construction trench was also encountered in Unit C1. This feature, labeled Feature 3, was first encountered at level 2 (4-8 inbd), and became more visible at the end of level 3 (12 inbd) (Figure 5-9). The soil of this feature was similar to the construction trenches in Zone $\mathrm{B}$, the brown, silty loam with flecks of black clay. As in Units B1 and B2, a course of five brick step-outs was also uncovered in this unit. As before, these bricks were left in place and not removed.

Architectural artifacts collected from this unit consist of 6.5 lbs of brick, or brick fragments, 0.5 $\mathrm{lb}$ of concrete, and one pound of mortar. Other artifact types collected include faunal remains, oyster and scallop shells, ceramic sherds, window glass, bottle and jar glass, glass tableware shards, metal hardware, nails, a buckle, buttons, and pencils (see Table 5-1). Of interesting note are two pieces of bottle glass and one piece of pressed glass. One bottle glass fragment was the base and body portion of a panel bottle. The maker's mark identified it as a bottle manufactured by the Illinois Glass Company between 1900 and 1916. The other bottle glass piece was the base of a brown whiskey flask embossed with a Federal Liquor Law stamp dating this piece between

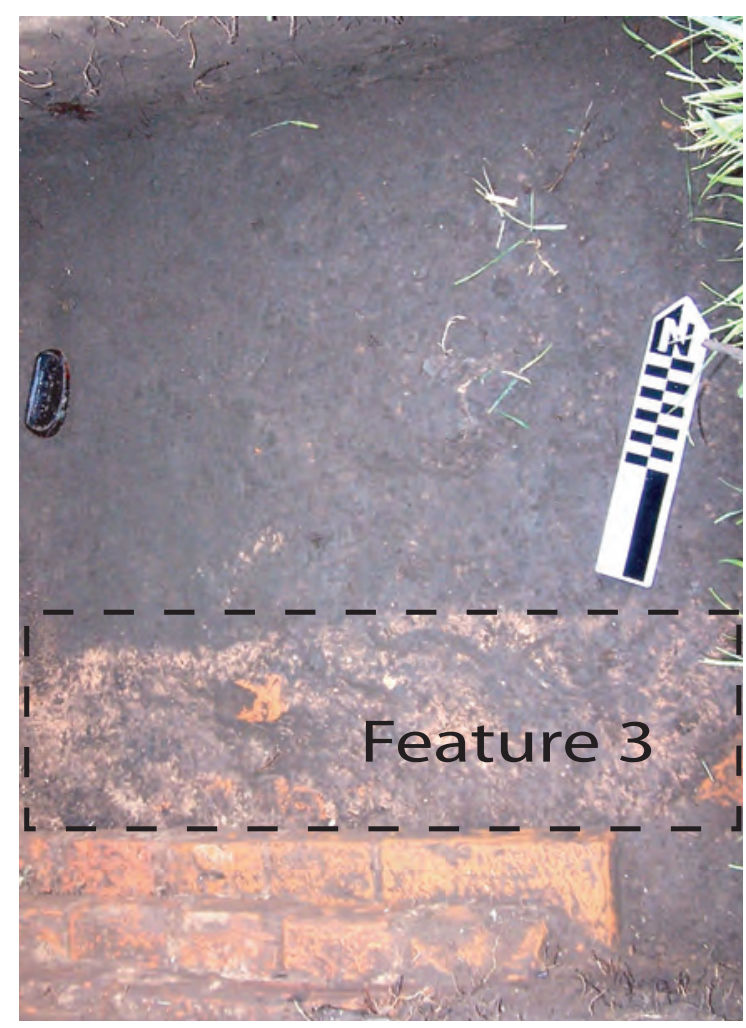

Figure 5-9. Photograph of Unit C1 level 3 (8-12 inbd) showing Feature 3, facing north. 
1932 and 1964. However, in the bottom level of the unit a piece of pressed glass identified as Lacy Glass dating from the 1840s to 1850 s was uncovered. These artifacts are discussed in detail in Chapter 6.

Unit C2 was excavated to depth of 16 inbd. Excavation of this unit uncovered the same construction features as Units B1, B2 and C1. A construction trench was encountered at the end of level 2 (8 inbd), becoming more visible in level 3 (8-12 inbd). Soil from this feature, labeled Feature 4, is the same as that in Zone B and Unit $\mathrm{C} 1$, the brown, silty loam with flecks of black clay. Like the previous unit, a course of five brick step-outs were also uncovered. An exploratory 12x6-inch column was also excavated next to the final course of brick step-outs (Figure 5-10). This column exposed the bottom of the brick stepouts and the bottom of the construction trench at approximately 16.5 and 17.5 inbd, respectively. Bricks were again left in situ.

A little over three pounds of brick and brick fragments, one pound of concrete, and $0.5 \mathrm{lb}$ of mortar were collected during excavations

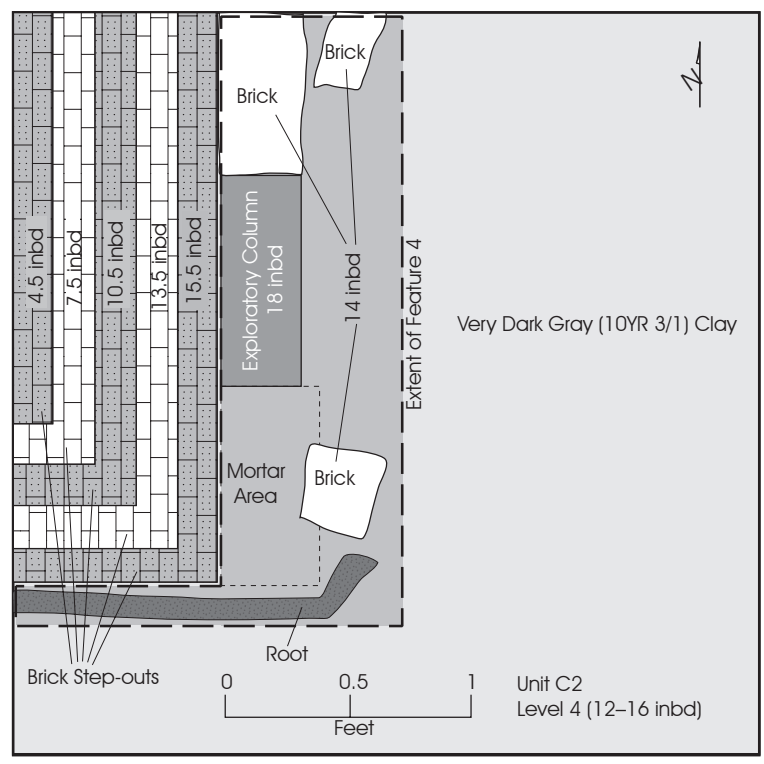

Figure 5-10. Illustration of Unit C2 level 4 (12-16 inbd) showing Feature 4 and exploratory column. of Unit C2. Other artifacts collected included faunal bones, ceramic sherds, drinking glass fragments, glass tableware fragments, bottle and jar fragments, lamp chimney fragments, munitions, nails, organic remains, oyster and clam shells, and a pearl bead (see Table 5-1). A large amount of window glass (608 shards) was collected from Unit C2. Groupings of this window glass were dated from the mid-1800s to the mid-1900s. Of interesting note is that the majority of this window glass dates to between 1910 and 1920.

\section{Zone D}

Two excavation units were located within Zone D, the area of the front porch. Unit D1 was placed at the southwest corner of where the concrete porch was once located, and Unit D2 was placed at the juncture of the concrete porch and house (see Figure 4-1).

Unit D1 was excavated to a depth of 16 inbd. No significant features or data related to the previously existing wooden porch were uncovered (Figure 5-11). Only a limited amount

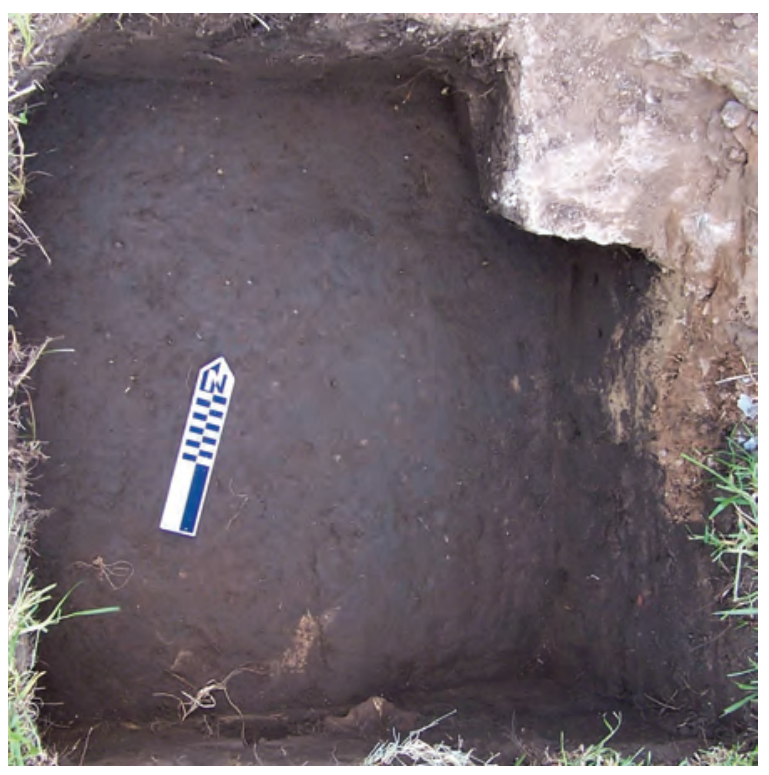

Figure 5-11. Photograph of Unit D1 level 4 (12-16 inbd), facing north. 
of architectural material, consisting of one pound of brick fragments and close to one pound of mortar, was collected from this unit. Several faunal bones encountered in the last level (12-16 inbd) were also collected. Ceramic sherds, pieces of bottle glass, lamp chimney glass fragments, window glass shards, drink glass fragments, fragments of metal hardware, munitions, round and square nails, oyster shells, and cloth were also collected (see Table 5-1).

Unit D2 was excavated to a depth of 16 inbd at the juncture of the porch and house. At the depth of 4-8 inbd, a brick walkway was encountered and labeled Feature 5 (Figure 5-12). This feature composed the southern third of the unit. Brick remains within the southwest profile of this unit indicated that this feature clearly extends further to the west and southwest of this unit. The northern edge of the feature consisted of well-defined bricks, while those toward the center are massed together and not as well defined. Feature 5 appears to have delineated the northern and eastern boundaries

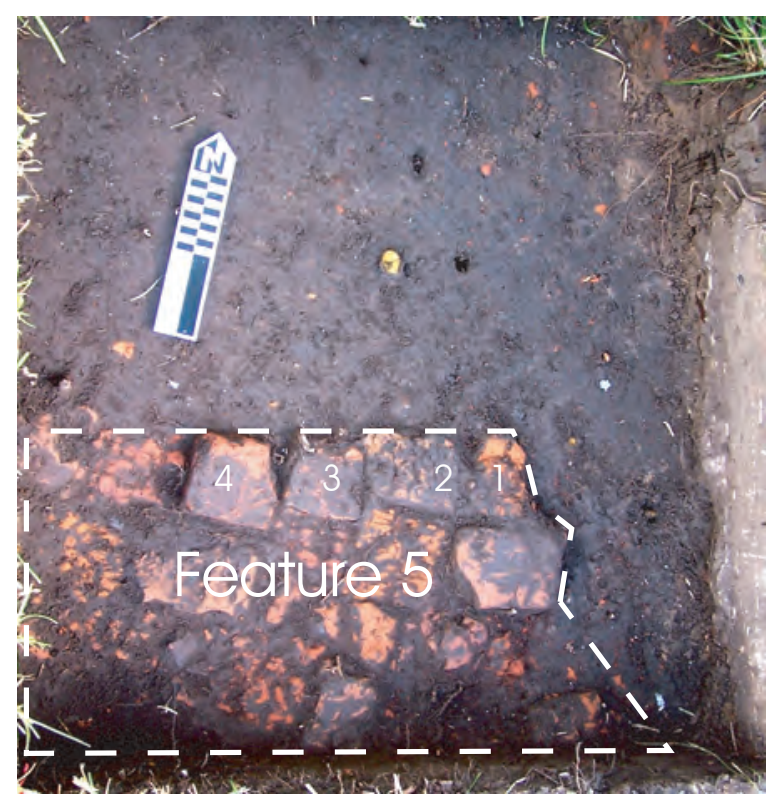

Figure 5-12. Photograph of Unit D2 level 2 (4-8 inbd) showing Feature 5 and numbered bricks, facing north. of this brick walkway. Bricks from this feature were removed and individually labeled.

At the bottom of Unit D2, approximately 16 inbd, handmade bricks utilized as footings for the house's original support piers became visible in the profile of the northeast corner of the unit (Figure 5-13). As this feature was not within the unit, it was not labeled or identified as a feature. However, its discovery is important in understanding the construction of the original house's pier and beam support system. A large number of window glass shards (766 shards) were collected from this unit, with groupings dating from the mid-1800s to the mid-1900s. Large quantities of ceramics and bottle/jar glass were also collected from this unit. Of interesting note were two pieces of a child's slate chalkboard recovered from beneath the brick walkway. Faunal remains, pieces of lamp chimney glass, fragments of metal hardware, tacks, screws, munitions, round and square nails, tableware

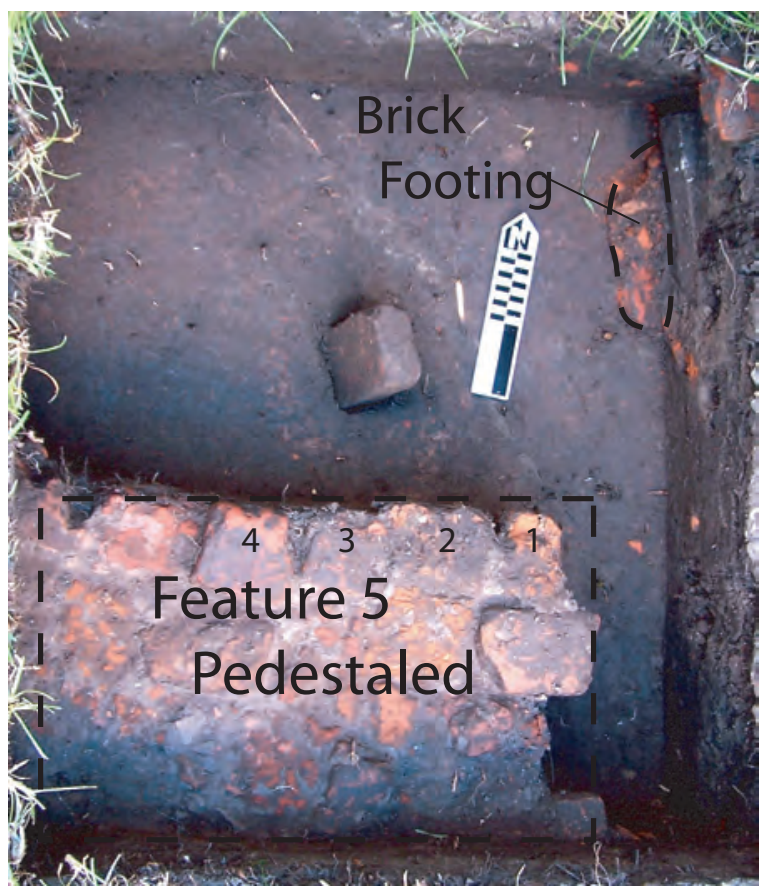

Figure 5-13. Photograph of Unit D2 level 4 (12-16 inbd) showing Feature 5 pedestaled with numbered bricks and brick pier footing, facing north. 
glass fragments, glass lid liner fragments, a glass button, a rubber medicine bulb, oyster shells, yarn, and cloth were also recovered (see Table 5-1). These artifacts are discussed in Chapter 6.

\section{Zone E}

Excavation units within this zone are located on the eastern side of the main plantation house (see Figure 4-1). Unit E1 was excavated to depth of 12 inbd. No features or soil color changes were encountered during excavation of this unit. This unit contained the largest amounts of artifacts collected during excavations. The majority of these artifacts were window glass (734 shards) dated from the mid-1800s to the mid-1900s. Slightly more than two pounds of nails were collected during excavations, with an even distribution of round to square nails. This unit also contained munitions, including three shotgun shells that date to between 1867 and 1902. A total of 2.5 lbs of brick fragments, faunal remains, ceramics sherds, bottle and lamp chimney glass fragments, drinking glass fragments, shards of tableware and lid liners, glass, porcelain and metal buttons, and oyster shells were also uncovered (see Table 5-1). Artifacts collected during excavation of this unit are discussed in Chapter 6.

Unit E2, located next to the current rear wing extension (see Figure 4-1), was excavated to a depth of 16 inbd. This unit was characterized by an overwhelming amount of brick fragments (Figure 5-14). There was indication of a previous excavation, lined with black plastic, in the northwest corner of this unit. At 16 inbd, a change in soil color was detected in the southeast corner. The soil change was labeled Feature 6, and was a well-defined square of a lighter brown soil that was very loose and soft (Figure 5-15). This 12x10-inch feature was excavated to 24 inbd. An eroded pipe was noted in the south wall profile at an

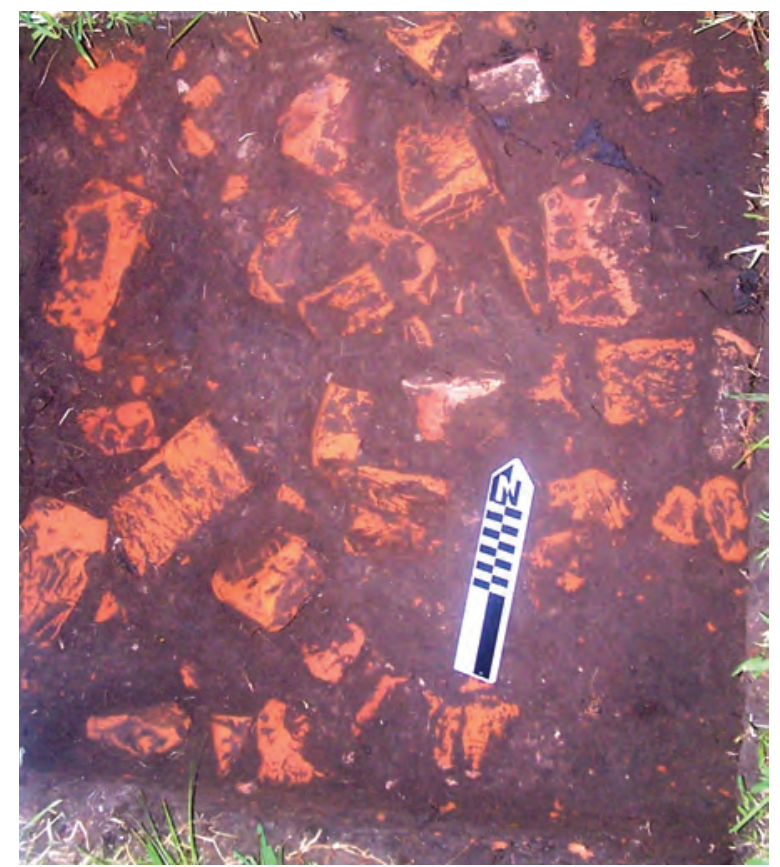

Figure 5-14. Photograph of Unit E2 level 2 (4-8 inbd), facing north.

approximate depth of 10-12 inbd (Figure 5-16). Window glass composed the largest majority of artifacts collected from this unit (239 shards). Unit E2 contained a large grouping of window glass dated to the late 1800s. Other interesting artifacts include a Buffalo Head nickel and a

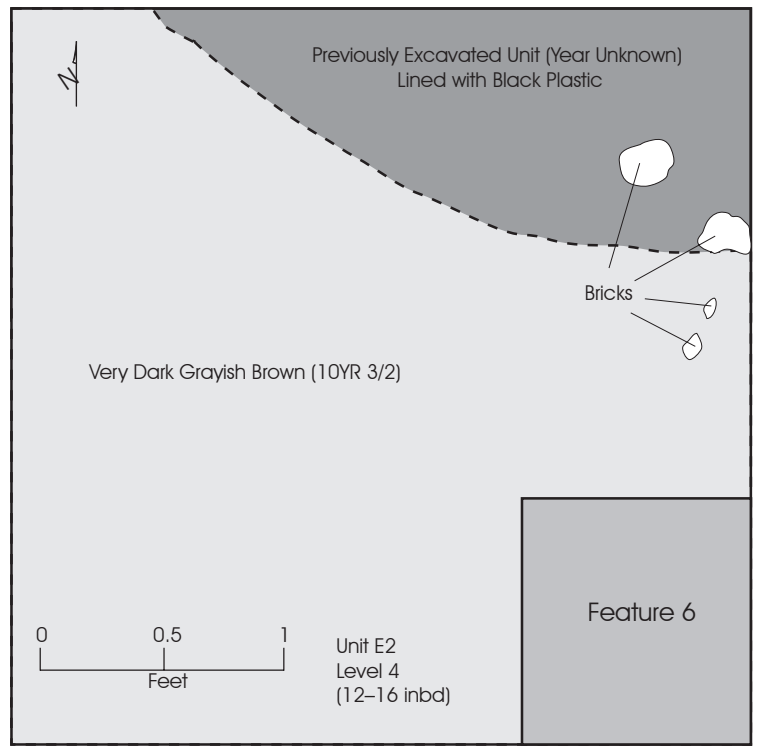

Figure 5-15. Illustration of unit E2 level 4 (12-16 inbd) showing Feature 6. 


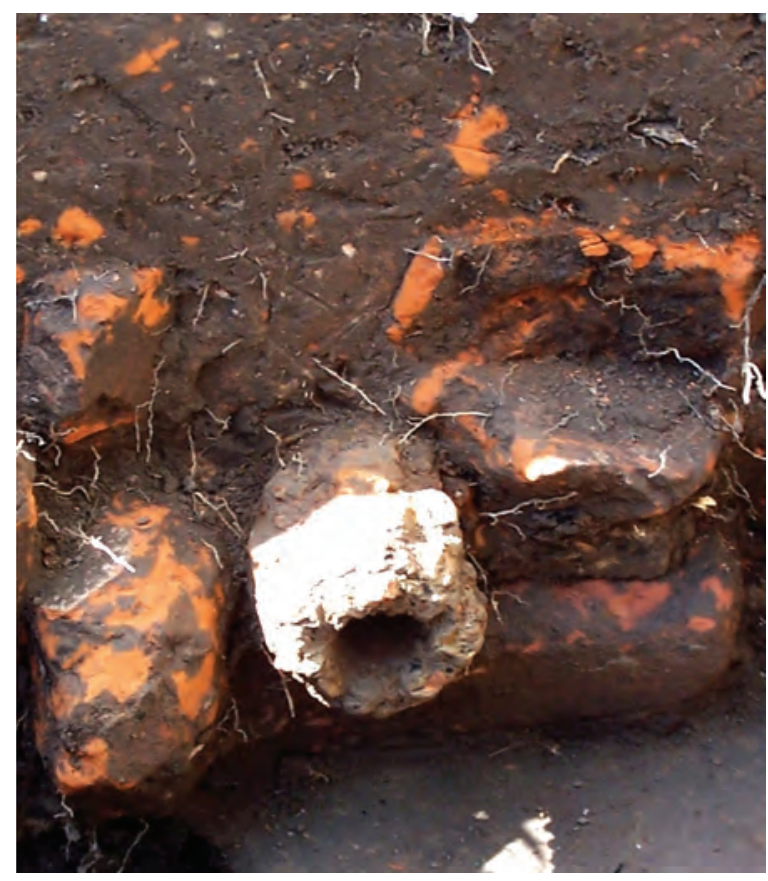

Figure 5-16. Photograph of eroded pipe in southern wall profile of Unit E2 at 10-12 inbd, facing south.

portion of a ceramic pitcher dated to between 1870 and 1916. While this unit contained a tremendous amount of brick fragments, only a small sample of less than ten percent (two pounds) was collected. Other artifacts collected include ceramic sherds, faunal remains, bottle and lamp chimney glass fragments, a piece of enameled metal vessel, metal hardware, munitions, nails, charcoal fragments, glass buttons, a brush handle, and oyster shells (see Table 5-1). Analysis of artifacts collected from this unit is presented in Chapter 6 .

\section{Zone G}

Unit G1, located north of the current rear wing extension, was excavated to a depth of 24 inbd (see Figure 4-1). No evidence of previous excavations was encountered during excavation of this unit. Two features were encountered at a depth of $4-8$ inbd. Feature 7 consisted of a handmade brick wall or foundation approximately 13.5 inches wide, which extended across the unit in an easterly direction. Feature 8 consisted of brick rubble located north of Feature 7 and composed the northern half of the unit (Figure 5-17). At the depth of 20 inbd, Feature 7 was fully exposed (Figure 5-18). Feature 8, the brick rubble, was removed during excavation in an attempt to determine its depth. Feature 8 was excavated to a final depth of 24 inbd in the northeast corner of Unit G1. This excavation revealed courses of brick (possibly a brick step-out of the brick wall/foundation) that were next to the brick wall/foundation and lined the northeastern edge of the unit (Figure 5-19). Unlike the other excavated units, this unit was covered in black plastic sheeting and backfilled. This was done in order to facilitate future excavations within this area and to identify this unit as previously excavated. Over 9.5 lbs of brick fragments and $0.25 \mathrm{lb}$ of mortar were collected from this unit. Few other artifacts were collected during excavation of this unit. These include one ceramic sherd, one bone fragment, four pieces of bottle glass, one piece of lamp chimney glass, several window glass fragments, a

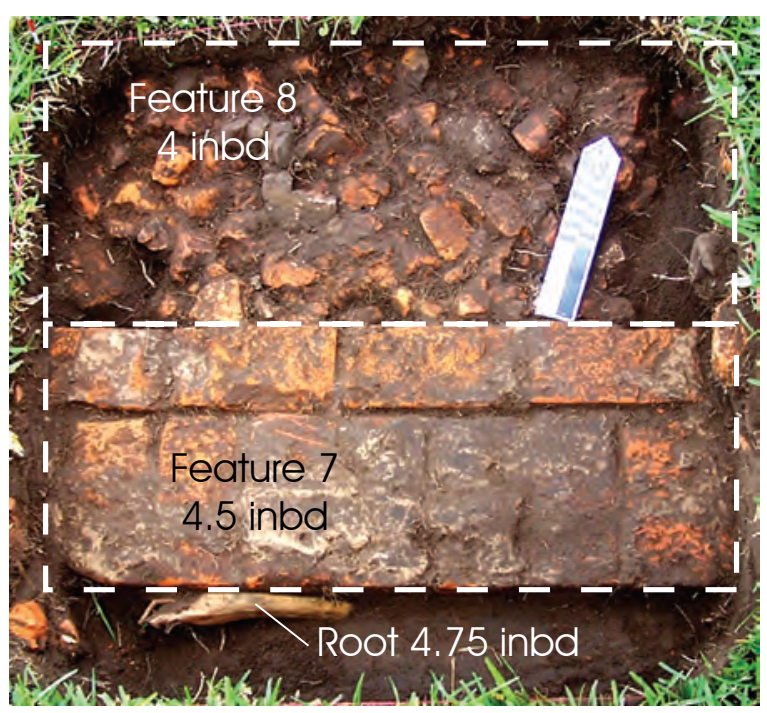

Figure 5-17. Photograph of Unit G1 level 2 (4-8 inbd) showing Features 7 and 8, facing north. 
penny, nails (the majority of which were square nails), buttons, a pencil fragment, and oyster and clam shells (see Table 5-1). These are discussed in Chapter 6.

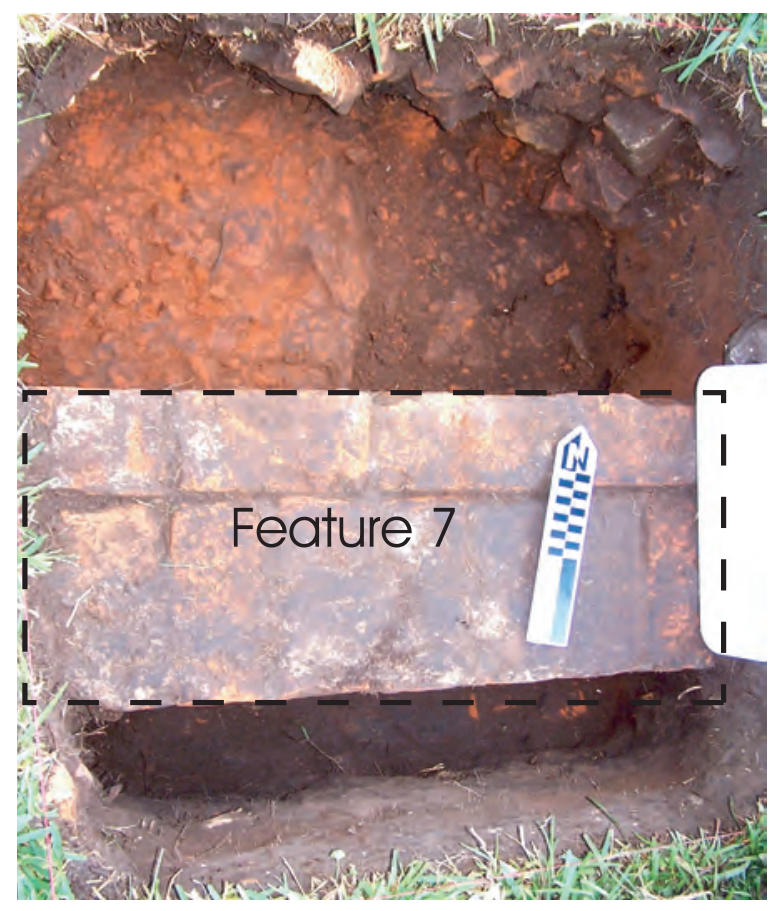

Figure 5-18. Photograph of Unit G1 level 4 (12-16 inbd) showing Feature 7 pedestaled, facing north.

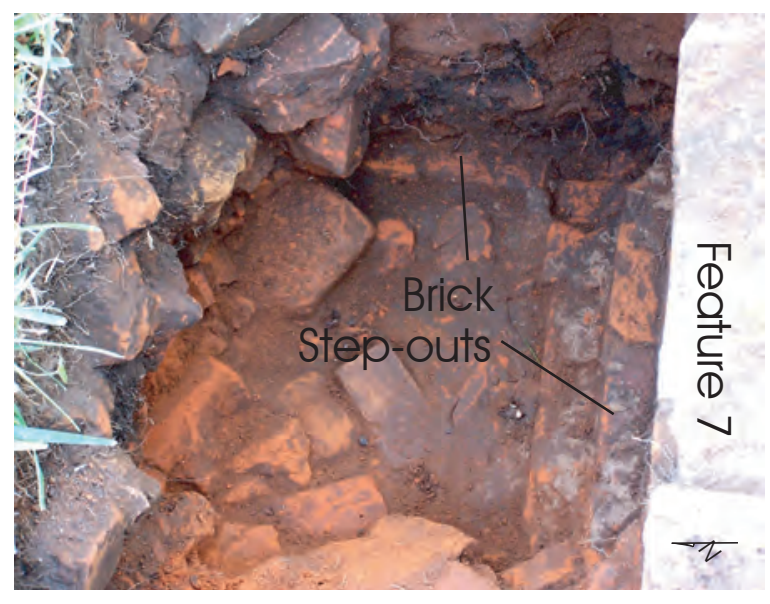

Figure 5-19. Photograph of Unit G1 level 5 (16-20 inbd) showing brick step-outs, facing east.

\section{Visitor Area (Zone Z)}

Investigations conducted in Zone $\mathrm{Z}$ included a pedestrian survey and the excavation of shovel test units. As previously mentioned, these efforts were somewhat obstructed by the dense vegetation in the research area.

\section{Pedestrian Survey}

A systematic pedestrian survey was conducted across Zone $\mathrm{Z}$ along transect lines spaced approximately 100 feet apart when possible. Due to the dense undergrowth, surface visibility was less than 10 percent. No archaeologically significant features or structures were encountered or identified.

\section{Shovel Tests}

A total of 36 shovel test units were excavated, two of which (STM and STMD) contained historic artifacts (see Figure 4-3). Artifacts recovered from these units included both handmade and glazed brick fragments. The location of these artifacts within these shovel test units warranted further investigation of this area, and Unit Z1 was placed in a location midway between STM and STMD.

\section{Excavation}

This unit was excavated to a depth of 12 inbd, upon which culturally sterile soil was encountered. Like STM and STMD, this unit also contained historical artifacts. Artifacts recovered from this unit consist of brick fragments (one pound), mortar, and bottle, window, and lamp chimney glass fragments (see Table 5-1). A glazed brick fragment was also exposed in the east wall of the unit at an approximate depth of 7.5 inbd. These artifacts are discussed in Chapter 6. 


\section{Chapter 6}

\section{Artifact Analysis}

Artifacts are the material remains of human activity. To the archaeologist, they provide a wealth of cultural information. The collection and study of artifacts encountered during excavations at the Levi Jordan Plantation provided insight into the way of life of antebellum plantations in Brazoria County, Texas.

A total of 10,045 artifacts were recovered from 36 shovel test units and 14 excavation units. Artifact remains included ceramics, glass, metal, munitions, ecological items, personal items, and architectural materials. Glass, ceramics, munitions, nails, bricks, and buttons will be discussed in depth, as they provide information on dates of occupation and/or construction, as well as insights into the behavior of the occupants of the main house.

\section{Analysis Methodology}

All recovered artifacts were processed and cataloged by CAS laboratory staff following the completion of the excavation phase of the Levi Jordan Plantation Project. Artifacts were processed and curated following standards established by the Texas Parks and Wildlife Department and published in the Archeology Lab Manual (TPWD 1995). Artifacts are permanently curated by TPWD.

Following initial processing, artifacts were sorted into the classification criteria (Appendix B) established by the University of Houston during previous excavations at the Levi Jordan Plantation (Brown 2005). These classifications are: Ceramics, Glass, Metal, Rubber, Lithics, and Ecology. Artifacts were further sorted to determine which artifacts possessed interpretive value based on an assessment of their diagnostic characteristics. Artifacts that have the potential to provide information on temporal and/or functional questions were selected for further analysis.

All ceramics were subjected to further analysis. In general, ceramics are extremely durable materials and survive well in archaeological contexts. In addition, they usually have diagnostic characteristics that allow for dating and identification of functionality. The fact that abundant publications contain comparative data on historic ceramics was also beneficial to the further analysis of this category of artifact.

Glass also survives well within archaeological contexts and was subjected to further analysis. Window glass proves to be very helpful not only in identifying construction episodes, but also in documenting environmental influences. Chimney, container, and tableware glass also provides valuable information concerning consumer behavior, consumption, and dating.

Metal artifacts are somewhat problematic within the archaeological record. As metal 
corrodes over time, it fragments and loses its diagnostic features, thus losing its interpretive information. Therefore, the majority of metal artifacts were not subjected to further analysis. However, metal items such as munitions, buttons, coins, and some nails and tableware were identifiable.

Although faunal remains can provide important information on dietary habits, the limited amount collected from excavations at the Levi Jordan Plantation was not subjected to analysis beyond identification of class (bird, mammal, or fish).

Although not all artifacts were subjected analysis, all artifacts were catalogued by type. As many artifacts as possible were identified, although some lack diagnostic attributes to allow for functional identification. In these cases, material type identifications were used. All artifacts were quantified by count and weight. Analysis focused on materials with the greatest amount of diagnostic information that could provide insight into temporal, spatial, and functional questions.

Artifact data was managed using a spreadsheet organized by catalogue number and artifact categories. Catalogue numbers consisted of provenience data (unit/level), artifact submaterial, and artifact class (see Brown 2005). The main artifact categories are: Ceramics, Glass, Metal, Rubber, Lithics, and Ecology. Artifacts were further divided into analysis classes of: Architectural Materials, Bone, Ceramic, Other Ceramic, Glass, Other Glass, Leather, Lithic, Metal, Other Metal, Modern, Munitions, Nail, Organic, Personal Items, Plastic, Rubber, Shell, Synthetic, Textile, and Unknown. All artifacts recovered from excavations at the Levi Jordan Plantation State Historic Site are presented in Appendix C.

\section{Glass}

\section{Bottle and Jar Glass}

The most reliable method for identifying bottle or jar glass is by dating a maker's mark. These marks provide information on approximate date and place of manufacture. In the absence of maker's marks, the manufacturing technique, labeling, and the color of glass can provide approximation of when it was manufactured. The shape of a bottle also provides clues to its contents and inferred use.

Glass color provides clues to its approximate date of manufacture and/or use. Glass bottles most commonly appear in varying hues of green and aqua. Amber, olive green, and brown are natural colors that are produced in glass manufacture, and were used during early stages of glass manufacture in the United States and Europe. Most bottles produced until 1900 were aqua with varying hues of green and blue. Glass color depends on the compounds present in the basic glass mixture (Munsey 1970:37). Table 6-1 lists these ingredients and their resulting color.

Up until the mid-nineteenth century, dark glass, or black glass, was the preferred type of glass container. This was based on the discovery

Table 6-1. Compounds added to glass to produce colors (Munsey 1970:37).

\begin{tabular}{|l|l|}
\hline Ingredient Added & Color Produced \\
\hline Copper, selenium, gold & Red \\
\hline Nickel, manganese & Purples \\
\hline Chromium, copper & Greens \\
\hline Cobalt, copper & Blues \\
\hline Carbon, nickel & Browns \\
\hline Iron & Greens, yellows \\
\hline Selenium & Yellows, pinks \\
\hline Tin, zinc & Opal or milk glass \\
\hline Iron slag & Black \\
\hline
\end{tabular}


that wines and spirits kept better in darker containers. By 1880, a demand for clear containers was generated by the growth of food preservation in glass containers (Munsey 1970:37). Beginning in 1880, American glass manufactures began to add manganese to their basic glass mixtures in order to produce a colorless, clearer glass. This continued until 1915, when the German source of manganese was cut off due to World War I. By 1916, American glassmakers had begun using selenium, a more expensive decolorizing compound. Selenium was eventually replaced by arsenic around 1930 (Munsey 1970:55).

Unknown to glassmakers utilizing manganese and selenium, these glass compounds change color when exposed to the ultraviolet light of the sun. If the glass contains manganese, it turns an amethyst color, and to a light amber color if it contains selenium. Of course, how much the glass changes color depends on the selenium or manganese content and how long the glass has been exposed to the sun (Munsey 1970:55).

A total of 532 bottle or jar shards were collected during excavations. Only five vessels and/or vessel fragments had attributes that could identify a manufacturer and or manufacturing date (Figure 6-1). The dates of manufacture of all the identifiable glass bottle and jar fragments correspond to occupation of the main house of the Levi Jordan Plantation, and are also supported by other dated artifact assemblages and historical documentation.

The base of a brown whisky flask with a federal liquor label was encountered in Unit C1. This embossed stamp states, "FEDERAL LAW FORBIDS SALE OR REUSE OF THIS BOTTLE” (Figure 6-1a). Following the repeal of prohibition in 1933, this statement was required to be embossed on the side or bottom of liquor bottles beginning on January 1, 1935 (Busch 1991). This requirement was passed to discourage the reuse of bottles by bootleggers and moonshiners. The law was repealed in 1964, therefore suggesting that this bottle fragment was manufactured between 1932 and 1964 (Bureau of Land Management 2005).

Five pieces of a bottle manufactured by McCormick \& Co., Baltimore, Maryland were collected from Unit D2 (Figure 6-1c). McCormick and Company began manufacturing extracts and fruit syrups in 1889 and continues in this capacity to this day (McCormick 2005). Therefore, these pieces could have been manufactured anytime since 1889.

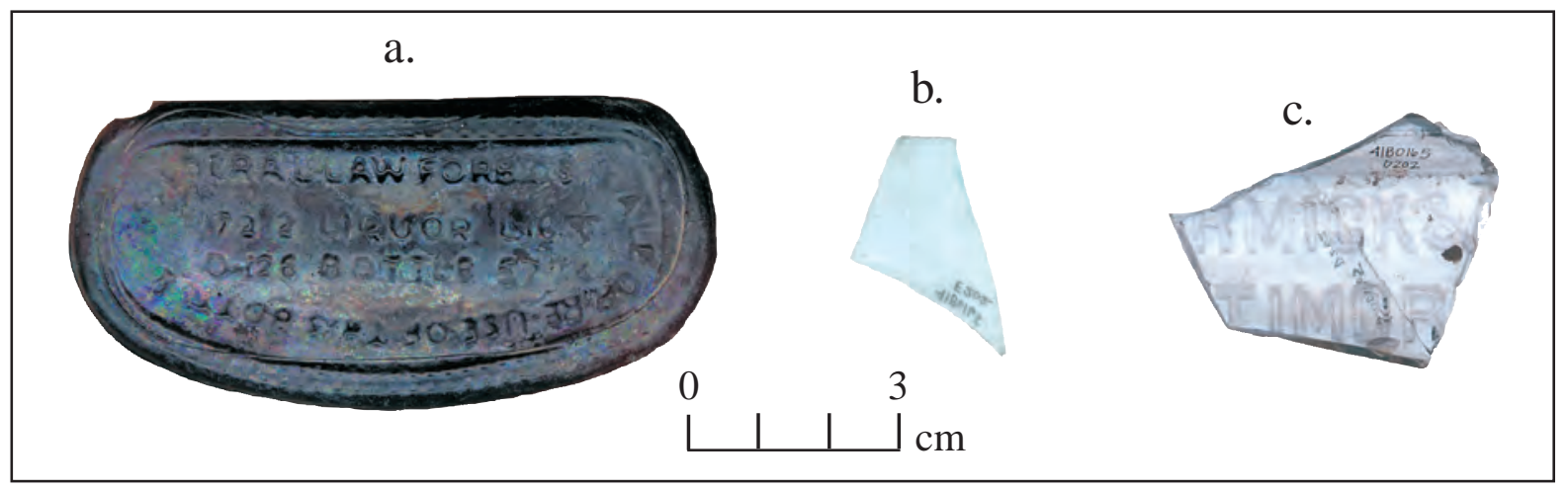

Figure 6-1. Embossed bottle glass fragments: (a) brown whiskey flask base with embossed federal liquor stamp; (b) mason jar fragment embossed with part of “58” from the "Mason's patent Nov. 30th 1858” series; (c) embossed panel bottle fragment McCormick \& Company. 
The term Mason jar is attributed to John Landis Mason, who was neither the inventor of the fruit jar nor a manufacturer. It was John Landis Mason who invented an inexpensive zinc screw lid in 1858 that was used in conjunction with glass lid liners to seal fruit jars (Munsey 1970:145). Following the expiration of John Landis Mason's patent in 1880, other jar manufactures began to emboss their jars with "Mason's Patent Nov. 30th 1858.” A piece of a Mason jar with the numbers " 58 " embossed on it was collected from Unit E2 (Figure 6-1b). Fruit jars with “Mason's Patent Nov. 30th 1858" embossing were widely manufactured between 1880 and 1912 (Toulouse 1971:345), suggesting that this fragment was manufactured during this time. Additionally, one whole and several fragments of glass lid liners were also recovered during excavations (Figure 6-2d).

The first patent medicine bottles were manufactured in England in the early 1700s and found their way to America with the colonists. The first patent for medicine in the United States was granted to Samuel Lee Jr. of Windham, Connecticut in 1796. The expression patent medicine became the generic term for all medicines sold over the counter (whether they were patented or not) and the name transferred to the bottles in which they were sold (Munsey 1970:65). The base of a panel-type, patent medicine bottle was recovered from Unit C1. It bore the maker's mark of the Illinois Glass Co. between 1873 and 1929 (Toulouse 1971:65). Because many patent medicines contained alcohol and/or strong narcotics, their use declined after the Pure Food \& Drug Act of 1906, which forced medicine manufacturers to disclose their ingredients (Munsey 1970:69).

In addition to the above-mentioned glass containers, one clear condiment bottle manufactured by Anchor Hocking Glass
Corporation was also recovered during excavation of Unit D2. This artifact was manufactured at the Anchor Hocking plant in Houston, Texas, sometime between 1962 and the present (Toulouse 1971:46-49; Cole 2005).

\section{Chimney Glass}

Lamp chimneys are open glass cylinders that were used to enclose a lamp flame, which created an artificial draftand a brighter flame. In an attempt to create a brighter flame, Ami Argand developed lamp chimneys in the 1780s in England. These types of glass lamps were patented in England in 1784, and thus appear in the archaeological record shortly thereafter. They were originally manufactured and decorated by hand, but by 1877 some types began to be manufactured by machine. Lamp chimneys are composed of an upper rim, a body, and a lower rim. Designs of lamp chimneys changed over time to fit changed lamp designs. Natural oils, turpentine, and alcohol mixtures were burned in lamps. Lamps with chimneys became popular with the use of kerosene fuels and burners specially designed to be used with glass chimneys (Sullivan 1984:58). By 1864, kerosene fuel lamps were the most commonly used lamps in North America (Russell 1968). Fragments of chimney glass are difficult to recognize in the archaeological record because they closely resemble drinking glasses (Sullivan 1984:58). However, they are often distinguishable from drinking glasses as they are usually handblown and are of a thinner glass. Additionally, unlike drinking glasses, lamp chimneys are not molded. They also have rims that are often ground, unfinished, and sometimes ruffled.

One hundred and eighty-eight fragments of chimney glass were collected during excavations of the main plantation house. The small size and the fact that the majority of these fragments lacked any identifiable markings made it impossible to date or to identify a manufacturer. However, six 


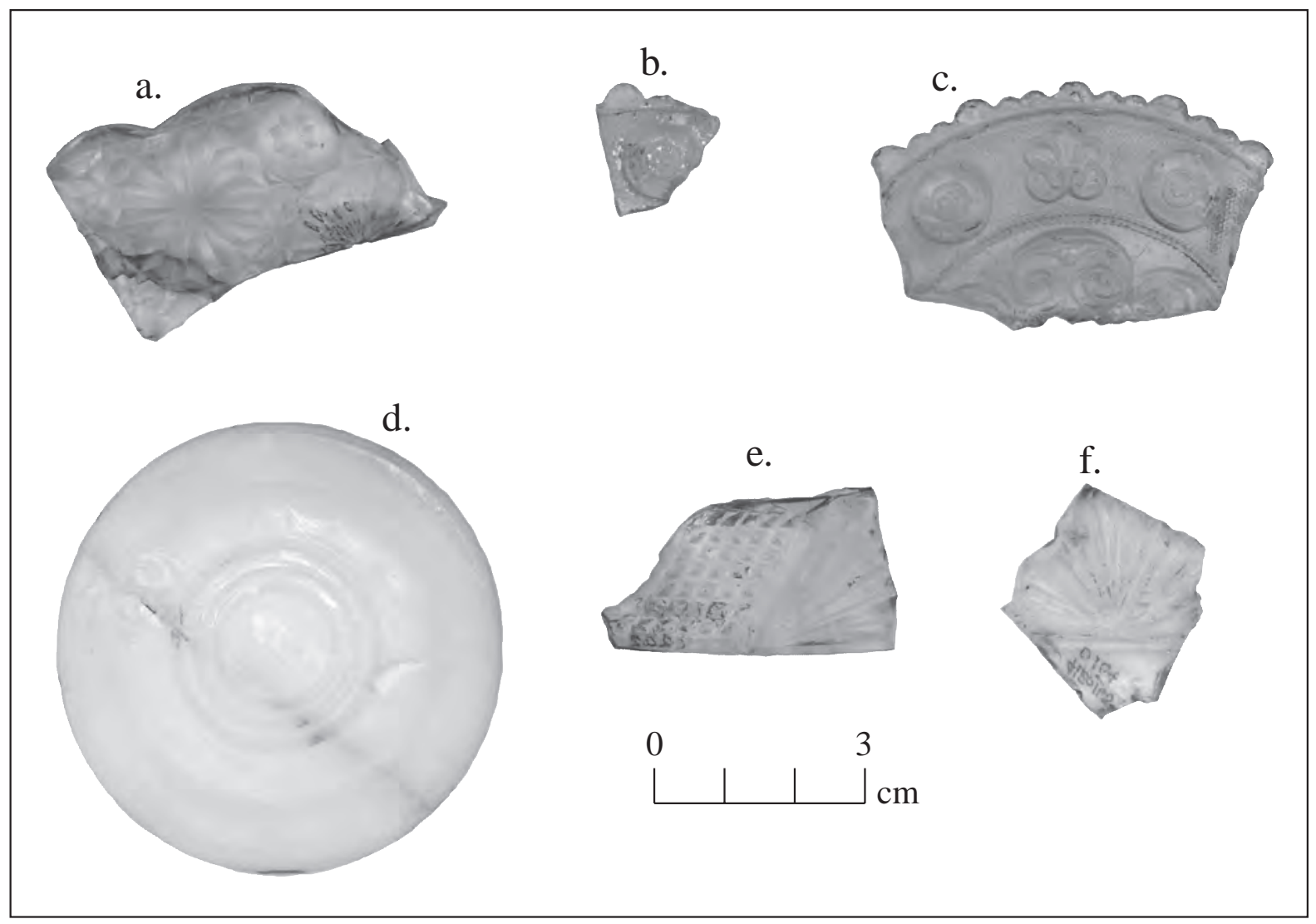

Figure 6-2. Examples of tableware glass and a mason jar lid liner: (a) pressed glass candy dish lid fragment; (b,c) 1840s Lacy glass; (d) opaque milk glass jar lid liner; (e) cut glass tableware fragment; (f) pressed or cut glass tableware fragment.

fragments from the same lamp chimney were collected from two different units, Unit A2 and Unit A5. Two of these shards refit, one from each unit, and have a semi-circular, zigzag design. These fragments appear to be from a domeshaped glass chimney decorated by acid etching, sandblasting, or flashing. These design features and manufacturing techniques are identical to those used by the Phoenix Glass Company circa 1897 (Sullivan 1984:63). This relative date of manufacture is within the range of occupation of the main house.

\section{Tableware Glass}

Tableware glass is defined as glass vessels that are associated with the consumption of food and beverage and include serving dishes, drinking glasses, and decorative vessels such as vases (Jones and Sullivan 1989:127). A small sample of 44 shards of this type was collected during excavations at the Levi Jordan Plantation. These include 23 drinking glass fragments; 18 molded, pressed, or cut fragments; 6 opaque milk glass fragments; and a wineglass stem (see Figure 6-2).

Of interesting note are two pieces of clear pressed glass that have been identified as Lacy Glass (Figure 6-2b,c). Lacy Glass was one of the earliest types of pressed flint glass manufactured in the United States (Husfloen 1994:163). The term flint glass was originally applied to fine glassware manufactured in England during the 1670s that contained powdered flint in the glass compound. Subsequently, flint was replaced with lead as it provided the glass with more clarity, 
resonance, and a better weight; however, the original name stuck. The name flint glass is also applied to leaded glass manufactured in the United States prior to 1860, and more precisely to pressed, leaded glass manufactured between 1820 and 1860 (Pattern Glass 2005). Between the 1820s and 1840s, the majority of these early pressed glass pieces, Lacy Glass, consisted of geometric designs and scrolls on a finely stippled background, giving it a lacy appearance. This glass type is also referred to as Sandwich Glass after the manufacturer, Boston and Sandwich Glass Company of Sandwich, Massachusetts. However, other glass manufacturers on the East Coast and in Pittsburgh, Pennsylvania, and Wheeling, West Virginia also produced this type of glass (Husfloen 1994:163). The manufacturing date of these two pieces of Lacy Glass pre-date occupancy of the Levi Jordan Plantation's main house, and may represent pieces of an heirloom glass vessel.

\section{Window Glass}

Measurements of window glass shards recovered from archaeological contexts within historic sites have provided valuable cultural and architectural information (Moir 1987a, 1988). Moir (1987a, 1998) observed that window pane thickness increased during the nineteenth century, and that important information concerning house construction can be derived from the study of window panes. He then derived an equation that dates the manufacture of window glass based on mean thickness in millimeters (mm), thus providing an initial construction date for the site (Moir 1987a, Day 2001):

manufacture date $( \pm 7 \mathrm{yrs})=$

$84.22 x$ (glass thickness in $\mathrm{mm}$ ) +1712.7

Moir (1987a, 1988) would contend that the Levi Jordan Plantation was not a viable site for this type of analysis due to its long occupation and the elevated socio-economic status of the occupants (Moir 1987a, 1988; Day 2001). As Moir applied his formula to the mean thickness of all window glass recovered, long occupation spans, additional construction, and building function would bias the mean date (Day 2001).

In his investigation of two historic structures near Lexington, Kentucky, Day (2001) employed this formula to analyze not only initial construction dates of the buildings, but also later additions to and remodeling of the structures. A temporal distribution would also indicate the occupancy span of the site. Based on his findings, it was determined that this formula could be applied to investigate the construction sequences of the Levi Jordan Plantation's main house. Furthermore, it was possible to compare samples from different parts of the house to verify oral history accounts of later additions and rebuilding. Therefore, measurements of the window glass shards recovered from the excavation units at the Levi Jordan Plantation were taken and the data analyzed using Moir's equation.

CAS archaeologists recovered 3,214 pieces of window glass from excavation units underneath or adjacent to the main house. The thickness of each glass shard was measured using digital calipers to the nearest $.01 \mathrm{~mm}$. Once measured, the total number and weight of the shards in each millimeter size group was recorded. The resulting information was entered into a database. However, due to variation in length, width, and thickness of each shard of window glass, counts and weights do not provide accurate representations of the quantity of window glass for each millimeter size. Calculating the surface area of the glass would be a more precise method of quantification. Barber (2003:188) used an index that determines the surface area $(I)$ of one face of a ceramic sherd from its weight $(W)$ divided by its thickness $(T)$ :

$$
I=W / T
$$


This equation is effective in quantifying window glass shards as well. The Glass Shard Index (GSI) was calculated for all glass recovered by dividing the weight by the thickness in millimeters. Glass shard thickness measurements were then entered into Moir's formula (1987), resulting in an associated date of manufacture for each fragment. These dates were then graphed chronologically by amounts (GSI) and presented in a histogram (Appendix A Figure A-1). Based on investigations by Day (2001) and Moir (1987a), the first significant rise of the histogram represents the initial construction date of the associated structure, in this case the main house on the Levi Jordan Plantation. Additional rises and peaks are representative of later remodeling or additions (Day 2001).

Analysis of the histogram suggests an initial construction date circa 1839. This date is established by the peak in window glass with a thickness of $1.50 \mathrm{~mm}$. The span of occupation of the Levi Jordan Plantation predominately falls between 1845 and 1990. These dates are supported by artifact assemblages and historical documentation. Historical documentation states that the property was purchased by Levi Jordan in 1848 and that the house was constructed between 1850 and 1857 (Freeman 2003:110-111). The use of window glass that was manufactured circa 1839 falls within the realm of possibility for the initial construction of the main house of the Levi Jordan Plantation, as window glass used in its construction could have been manufactured several years prior to its use.

The additional elevated peaks of window glass correspond to the occupation of the site by Jordan and his descendents. Moir (1987a) and Day (2001) would attribute the sharp increase in glass to periods of additional construction and remodeling. While this appears true at the Jordan Plantation, a consultation of hurricane records of southeast Texas suggests the reason for this additional construction and remodeling.

A review of historical data on hurricanes that impacted the southeastern Texas coast correlates the greatest peaks in window glass with dates of hurricanes ( \pm 7 years). The 1854 hurricane that hit Matagorda and Galveston closely corresponds with the second major peak in the histogram (see Appendix A Figure A-1). During this hurricane, the town of Matagorda was leveled and Galveston experienced flooding from the storm surge. Furthermore, Brazoria reportedly encountered strong, damaging winds from the storm. An 1867 hurricane roughly corresponds with the third peak. This intense and destructive storm followed the same route as the famous Racer's Storm of 1837, leaving a path of devastation along the entire coast. An even more devastating storm hit San Jose Island in 1875 , corresponding with the fourth peak in window glass. This storm crossed into Copana Bay, moved inland, and destroyed the lighthouses at Cavallo Pass and the town of Old Velasco. The hurricane of 1888 that hit Galveston corresponds with the fifth peak, while the Great Galveston Hurricane of September 1900 corresponds with the highest peak in the chart. This hurricane remains on record as the worst natural disaster in the U.S., with an estimated 8,000 lives lost (Roth 2005). According to oral history, the hurricane of 1900 removed the kitchen-dining room annex of the main house of the Levi Jordan Plantation (Freeman 2003). During this storm, the first floor on the south, east, and north sides was damaged along with the roof, resulting in the replacement of the roof and rebuilding of the kitchen (The Brazosport Facts, July 18, 1993:12).

The fact that these dates correlate with documented hurricane events clearly demonstrates the accuracy of Moir's formula. Furthermore, in most cases these dates deviate 
by only 4 years, not the 7 years that Moir factors. This evidence also serves to legitimize the application of this formula to the analysis of construction sequences at the Levi Jordan Plantation, even though the site is not considered an ideal candidate for this methodology.

While the analysis of window glass thickness provides information concerning construction sequences of the main house, the events necessitating these construction phases are also important to examine. The correlation between window glass and historically recorded hurricanes demonstrates the importance of environmental factors on the lives of the occupants of the Levi Jordan Plantation. Destruction by these hurricanes forced the rebuilding of some sections of the main plantation house and replacement of broken window panes in surviving sections. The effects of these environmental factors are clearly evident in the peaks of window glass amounts following hurricanes.

\section{Ceramics}

The study of historic ceramics is often based on typologies established by the examination of seventeenth- and eighteenth-century artifacts. These typologies rely on ware classifications. While these classifications are reflective of the classificationsystemsinuse during the seventeenth and eighteenth centuries, they are, however, not reflective of classifications systems employed by individuals in the nineteenth century. By the nineteenth century, the success of the English ceramic industry resulted in the reduction of the range of wares available. Fine ware types such as tin-glazed earthenware and white salt glazed stoneware were replaced with English white earthenware (Miller 1980:3-4). Classification of this ware by nineteenth-century manufacturers and consumers shifted to a reliance on decoration type (Miller 1980:4). As the focus of the analysis of the ceramics recovered from the Levi Jordan Plantation is a socioeconomic examination, it was considered most advantageous to utilize a classification system based on decorative types.

A total of 365 ceramic sherds were recovered during excavations of units within or next to the main plantation house. Ceramic sherds were classified into Creamware, Pearlware, White Earthenware, Ironstone, Porcelain, Yellowware, Stoneware, Colonial Wares and Other Ceramics. This classification system was chosen because it was most representative of the classification system employed by the nineteenth-century occupants of the Levi Jordan Plantation.

\section{Creamware}

Creamware is a hard paste/refined earthenware. Hard paste earthenwares are the end product of highly fired, refined clays with vitreous glazes and wide-ranging decoration styles (Stothert et al. 1992). Glaze is a thin, watery, glass-based compound applied to ceramic vessels prior to firing. This glaze melts during firing and provides an impervious glassy layer with decorative qualities.

England's conquest of the world ceramic market was greatly enhanced by the production of creamwares beginning in the late eighteenth century (Miller 1980:4). By 1762, Josiah Wedgewood had perfected the appearance of creamware (Noël Hume 1969:124). Creamware is a thin, hard-fired, cream or pale yellow earthenware that was dipped into a clear glaze following a preliminary firing (Noël Hume 1969:125). The development of creamware is considered to be the most important ceramic development of the eighteenth century (Noël Hume 1969:123). It is from creamware that bluetinted pearlware evolved in the 1780s, then white earthenwares in the 1830s, and finally ironstone in the 1850s. Seven sherds of undecorated 


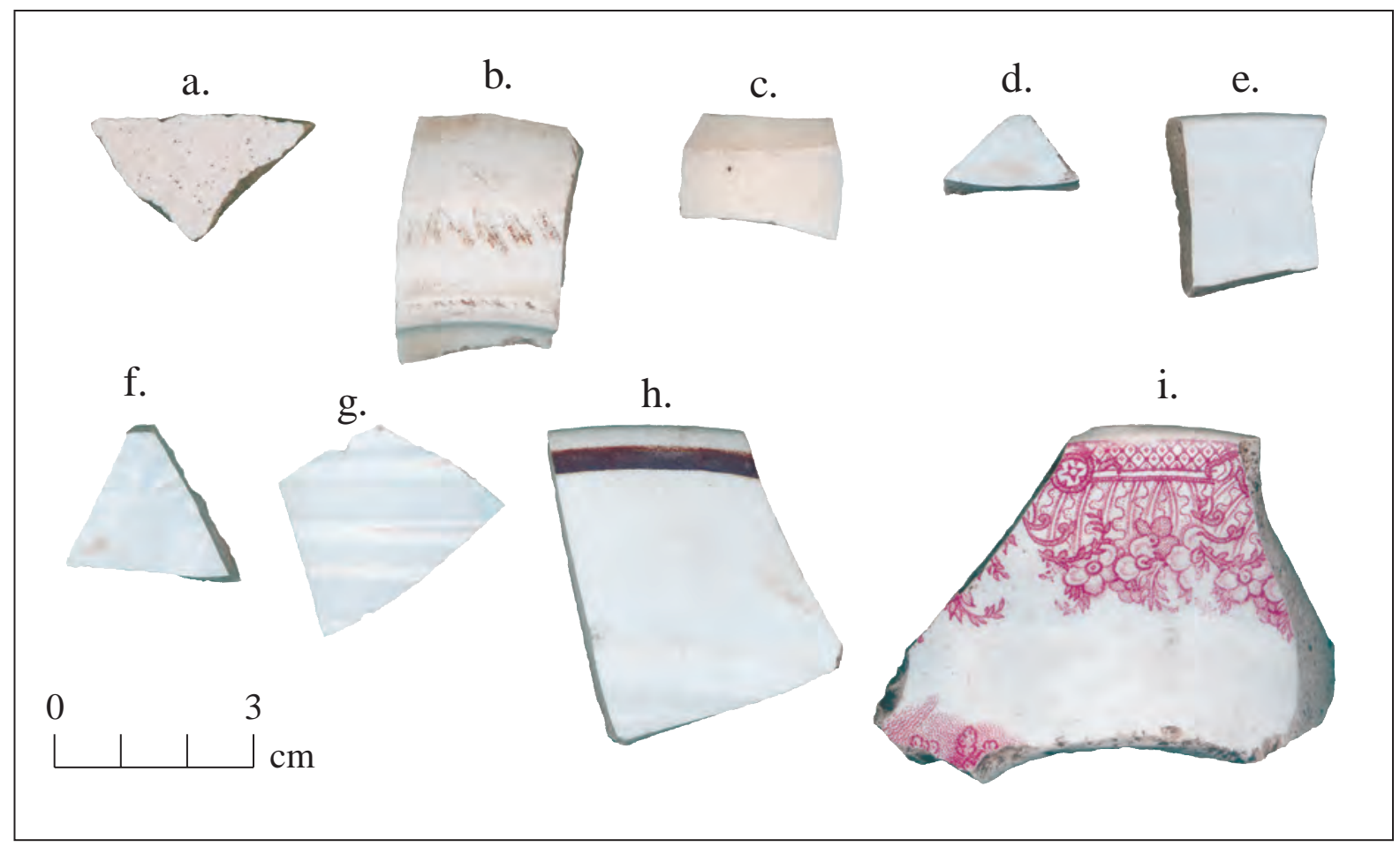

Figure 6-3. Yellowware, creamware, pearlware, and ironstone: (a) yellowware; (b,c) creamware; (d,e) pearlware; (f,g) molded ironstone; (h) ironstone hotelware; (i) ironstone red transfer soup tureen lid.

creamware were recovered from Unit C2 and Zone D (Figure 6-3b,c).

\section{Pearlware}

Pearlware evolved from creamware in the late eighteenthcentury.Itsdevelopmentwasinfluenced by a decline in the demand for creamwares and the ability of potters to incorporate Cornish china clays into ceramic production. This allowed potters to develop a ceramic product that was very similar to high-end hard paste porcelain. The success of pearlware was further enhanced by the establishment of English tariffs against the importation of porcelain; in 1799, the tax rate on Chinese porcelain was over 100 percent. Pearlware is distinguishable from its creamware predecessor by the incorporation of a bluish tint in the glaze that produced a whiter, porcelain-like appearance (Miller 1980:14). Only two sherds of pearlware were recovered from excavation in Unit D2 (Figure 6-3d,e).

\section{White Earthenware}

The majority of ceramics recovered from excavations were white earthenware (53 percent). Of the 195 white earthenware sherds collected, 8 were unglazed, 159 were undecorated, and 28 have some type of decoration (Figure 6-4). White earthenware was first produced in England in the 1830s (Tennis 1997:2). When placed next to creamware itappears dull white due to a lack of lead in the glaze (Moir 1987:98). White earthenware generally has a whiter paste than its creamware predecessor (Moir 1987:98), and is often lighter and more porous than its ironstone successor (Miller 1980:14). While white earthenware most commonly appears undecorated, it also occurs in molded forms and with transfer prints (Moir 1987:98). Examples of transferware, flow blue, spongeware, decalcomania, edgeware, and fiestaware are represented in this assemblage. 


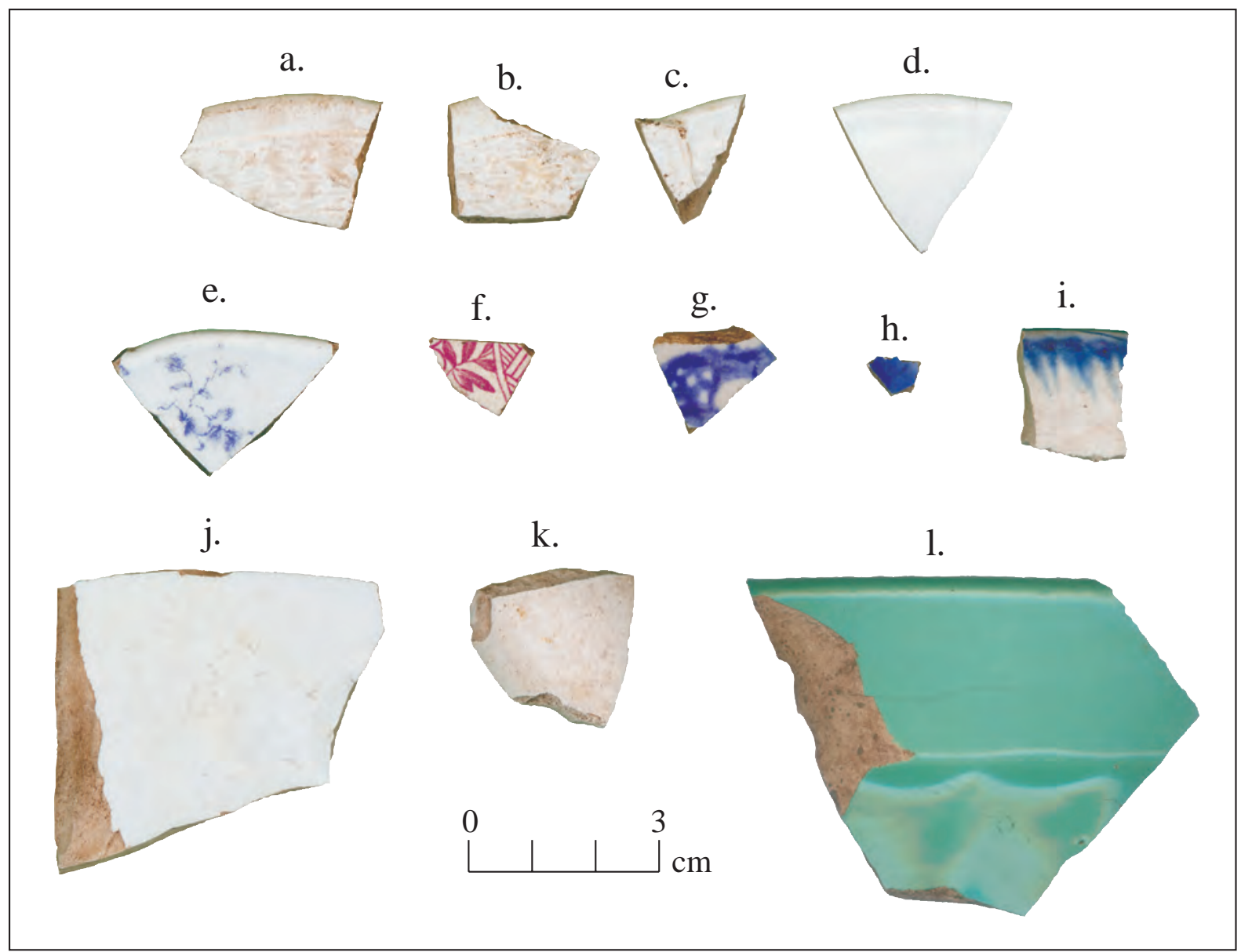

Figure 6-4. White earthenware: (a,b) molded "Basketweave” design; (c,d) molded; (e) blue decalcomania; (f) mauve transferware; (g) blue spongeware; (h) flow blue; (i) blue feather edgeware; (j) undecorated; (k) unglazed; (l) fiestaware

\section{Transferware}

Transferware vessels are created through a process known as transfer printing (May 2005). This process involves the etching of the transfer design on a copper plate that is then inked. This inked design is then transferred to a special type of tissue paper that is then placed on the vessel to be decorated. The vessel is then glazed and refired, sealing the transfer design to the vessel. John Sadler and Guy Green first manufactured this type of decorated ceramic in England in 1756 (May 2005). This decoration style remained fashionable in the United States through the 1850s (Tennis 1997:6). Popularity resurged in the last quarter of the nineteenth century, but it was replaced by decalcomania wares by the beginning of the 1900s (Miller 1991:9). Prior to the development of transferware, decorated ceramics were limited to hand-painted vessels. As this was a time consuming and labor intensive process, only the very wealthy could afford decorated dinner settings. With the development of transferware, decorated vessels were able to be mass produced and available to a wider market. One fragment of a mauve transfer print was recovered from Unit D2 (Figure 6-4f). Red and mauve transferwares were very popular between 1830 and 1840 (Nickels 2003:62).

\section{Flow Blue}

Flow blue is distinguishable by deep cobalt blue decoration. This decoration process was 
first created in England in the 1830s while attempting to create cheaper versions of Chinese porcelain vessels (Snyder 1995:7). By 1875, flow blue vessels were produced in the United States (Snyder 1995:9). This type of ceramic decoration received its name from the tendency of the vessel's transfer prints to "flow" or bleed during the firing process, resulting in a blurred image (Snyder 1995:8). One fragment of flow blue was recovered from Unit E1 (Figure 6-4h).

\section{Spongeware}

Spongeware vessels are characterized by their speckled appearance. This appearance is accomplished by stamping color onto the vessel with a sponge; hence the name. Often, these sponges are cut into unique shapes or designs. This decoration process was invented in 1845 (Robacker and Robacker 1978:80) and produced by English potteries from the mid- to late 1800s (Majewski and O’Brien 1987:161). During the nineteenth century, this decorated type of white earthenware was considered to be the cheapest decorated vessels available (Sauer, Black and Brandimarte 1998:56). One fragment of a spongeware vessel was recovered from Unit E1 (Figure 6-4g).

\section{Edgeware}

Edgeware is identified by decoration along vessel edges. Designs include painted or incised shell or feather designs. Edgeware was manufactured in England and became popular in the United States by the end of the eighteenth century through the beginning of the nineteenth century (Tennis 1995:4). The one piece of edgeware recovered from Unit D1 (Figure 6-4i) is a blue, feathered-edge type that was popular in the U.S. through the 1860s (Miller 1991:6).

\section{Decalcomania}

Decalcomania, or decal, decoration is created by applying a printed decoration or design to the surface of the vessel. It differs from transferware in that decals are applied over the glaze and refired in a "decorating kiln" (Majewski and O’Brien 1987:146). Decal appears on imported porcelains prior to 1900; however, by the turn of the century, they were produced more cheaply on white earthenwares. It remained a popular style for dinnerware from 1900 until the 1950s (Majewski and O’Brien 1987:147). Twelve decaldecorated white earthenware fragments were collected from Units A1, A3, B2, C2, E1, and E2 (Figure 6-4e).

\section{Fiestaware}

Fiestaware comes in a wide variety of glaze colors. Experimentation with differing glaze colors began among American potteries in the 1930s (Moir 1987b:103), and fiestaware was introduced by the Homer Laughlin Company of Newell, West Virginia in 1936 (Ketchum 2000:141). One piece of fiestaware was recovered from Unit B2 (Figure 6-4l). This piece is a light green rim of a large bowl. Fiestaware mixing bowls were made between 1936 and 1943 (Kovel and Kovel 2002).

\section{Ironstone}

The term ironstone originated with “Mason's Patent Ironstone China” that was patented in 1813 (Godden 1980:102). This vitrified or semi-vitrified ware has a slight blue tint that appears absent when placed next to pearlware (Miller 1991:10). Ironstone is distinguishable from white earthenwares by its denser, almost non-porous paste (Miller 1991:9-10). Ironstone vessels produced prior to the 1830s are often characterized by a combination of decorations including painting, printing and enamelling (Miller 1991:10). Eighty-one sherds of this classification were collected from excavation units and include undecorated, molded (Figure 6-3f,g), red transferware, and brown-banded hotelware pieces (Figure 6-3h). The large fragment of a red 
transfer-decorated soup tureen lid was collected from Unit D1 (Figure 6-3i). Transfer patterns of red color were popular between the 1830s and 1840s (Nickels 2003:62). The majority of these sherds were undecorated, however, suggesting that they date sometime after the 1830s, as ironstone produced after this date tend to lack any decoration (Miller 1991:25).

\section{Porcelain and Semi-Porcelain}

Porcelain and semi-porcelain ceramics result from the high firing of fine-grained clays containing the mineral Kaolin (Tennis 1997:15). These translucent, vitrified ceramics were first developed by the Chinese and later copied by Europeans and Americans (Husfloen 2000:3). English porcelain was first manufactured at Chelsea, England, by Nicholas Sprimmons in
1744 (Mackay 2002:13-14). Decorated porcelain is often relied upon as an economic marker because it was more expensive than similarly decorated white earthenwares and ironstones (Miller 1991:15). Thirty-eight sherds of English porcelain, eleven sherds of English semiporcelain, and one sherd of Japanese porcelain were recovered during excavations (Figure 6-5). While porcelain production was introduced to the Japanese in the later part of the seventeenth century by Korean immigrants (Mackay 2002:21), the Japanese porcelain fragment collected during these excavations (Figure 6-5b) is of a recent date.

\section{Yellowware}

Yellowware is a semi-refined earthenware ceramic with a light, sandy yellow to buff

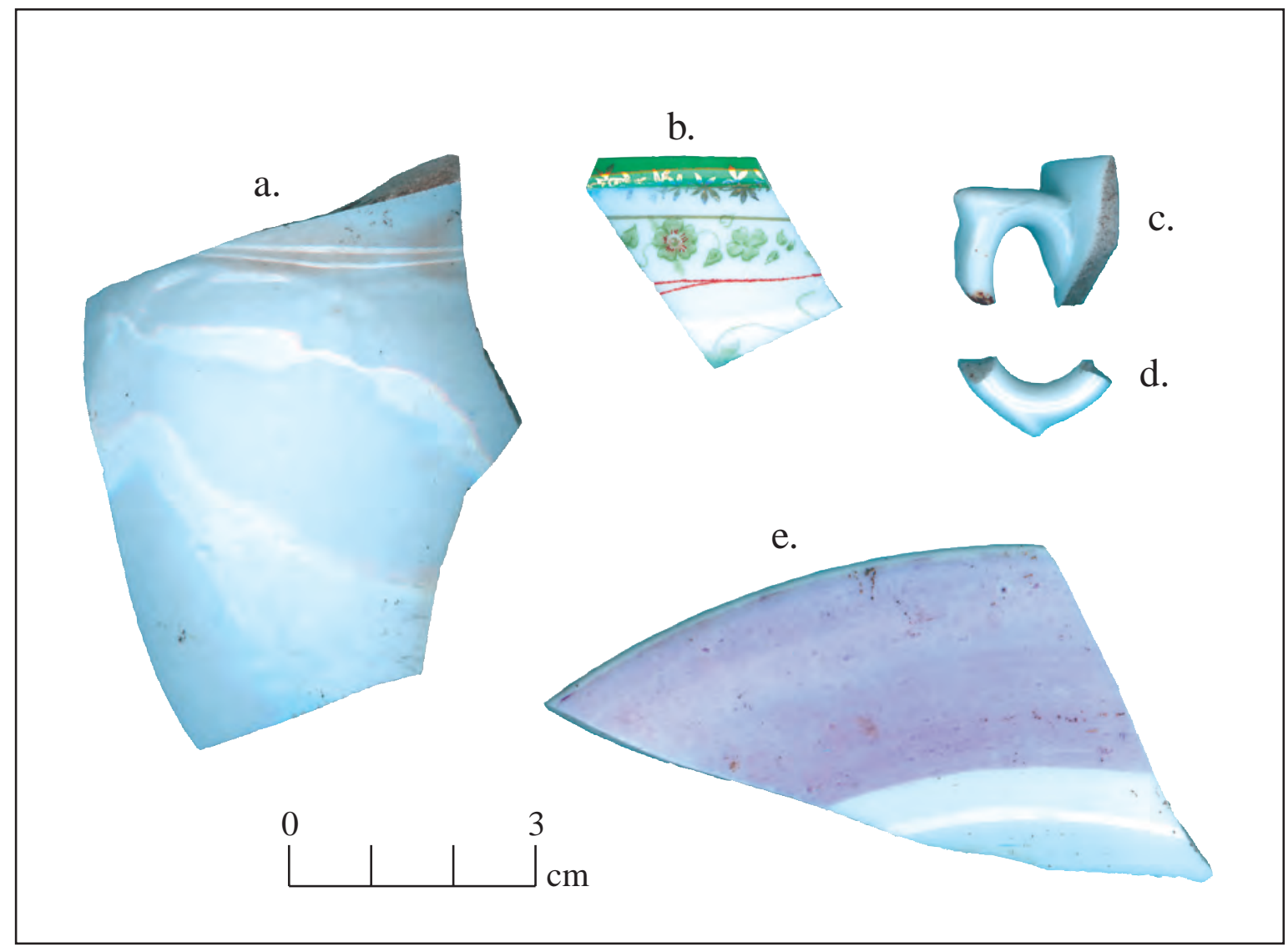

Figure 6-5. Semi-porcelain and porcelain: (a) semi-porcelain pitcher fragment; (b) gilded Japanese porcelain rim; (c,d) porcelain teacup handles; (e) handpainted porcelain plate rim. 
coloration (Moir 1987b:99). This form of utilitarian pottery was manufactured in Europe as well as the United States from the early nineteenth century until the present (Husfloen 2000:375). This type of ware often received a clear slip, giving it a yellow appearance; however, mocha-colored designs and later color glazes were applied (Moir 1987b:99; Husfloen 2000:375). Its paste is less dense than stoneware and impervious to water (Husfloen 2000:375). Only one piece of yellowware ceramic was collected from Unit E1 (Figure 6-3a).

\section{Stoneware}

Stoneware is produced from natural clays that have been fired to temperatures between $1200^{\circ}$ and $1400^{\circ} \mathrm{C}$. This results in a vitrified, nonpermeable vessel that varies in color from white to brown, with some shades of gray, depending on clay composition. While these vessel types do not require glazing, by the midnineteenth century, stoneware ceamics appeared with glazing on both the inside and outside of the vessel (Tennis 1997:16). These ceramic containers replaced earlier lead-glazed earthenwares as the preferred utilitarian and storage vessel (Greer 1981). Stonewares were manufactured in the United States using methods imported by European immigrants (Greer and Black 1971). The earliest potteries in Texas were established near the clay sources of the Wilcox geological formation in Bexar, Wilson, and Guadalupe counties (Greer and Black 1971). Salt glazing was the most popular form of stoneware glazing in the United States in the nineteenth century. Between 1860 and 1900, it was common to combine an Albany slip glazed interior with a salt glazed exterior. After 1870, Albany glazes, a dark brown slip made from an Albany, New York clay, became popular. Albany slip provided a reliable glaze when fired at a variety of temperatures that resulted in a smooth, deep chocolate brown, blackish-brown, or yellowish-brown(Greer 1981). One piece of stoneware with an Albany-slipped interior and salt-slipped exterior was recovered from Unit E2 (Figure 6-6d), while one piece of Albany-slipped interior and exterior stoneware was found in Unit C1 (Figure 6-6e). Units A3 and C1 contained a total of four pieces of unglazed stoneware (Figure 6-6b,c).

\section{Colonial Wares}

A single ceramic fragment was collected from Unit C2 that dates to the colonial period (Figure 6-6a). This fragment is a smooth brownware. Smooth brownware vessels are characterized by a fine-grained, red paste covered on both sides with a smooth, clear lead glaze, allowing the paste color to show through. They commonly appear as shallow bowls and plates with flat bases and no

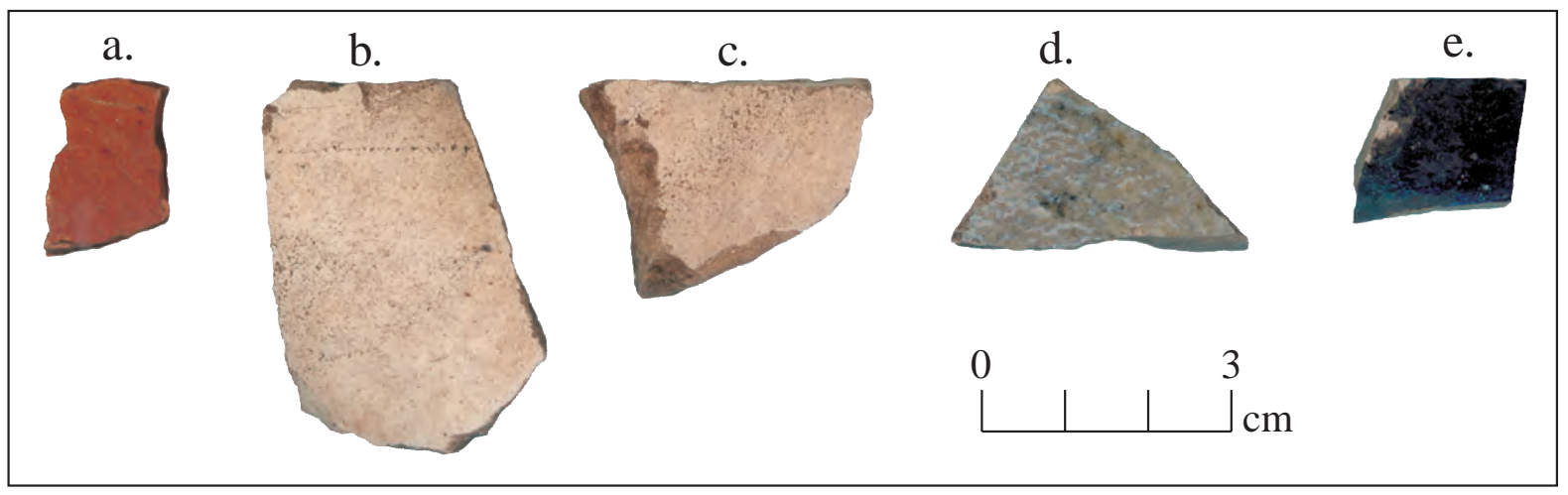

Figure 6-6. Brownware and stoneware: (a) smooth brownware, colonial; (b,c) unglazed stoneware; (d) stoneware, Albany-slipped interior, salt-slipped exterior; (e) stoneware, Albany-slipped interior and exterior. 
foot rings, and were probably manufactured in Mexico. Vessels of these type are commonly recovered from historic San Antonio sites dating to the early nineteenth century, in addition to mission sites dating after 1790s (Fox 1995).

\section{Vessels with Maker's Marks}

Eight pieces of ceramics recovered from the Levi Jordan Plantation exhibit complete or partial maker's marks (Figure 6-7). The earliest discovered maker's mark on a piece of American pottery is attributed to a small creamware fruit dish manufactured by
Bonnin \& Morris in Philadelphia around 1770. While no early American pieces were encountered during excavations at the Levi Jordan Plantation, a white earthenware base was identified that was manufactured by the La Belle Pottery Company of Wheeling, West Virginia circa 1850 to 1895. Four maker's marks are of English pottery manufacturers from the same period (Table 6-2). The remaining three are unidentified, although they employ designs that were commonly used in maker's marks of the mid- to late 1800s (Table 6-3). By the mid-nineteenth century, refined earthenware ceramics were manufactured in the United

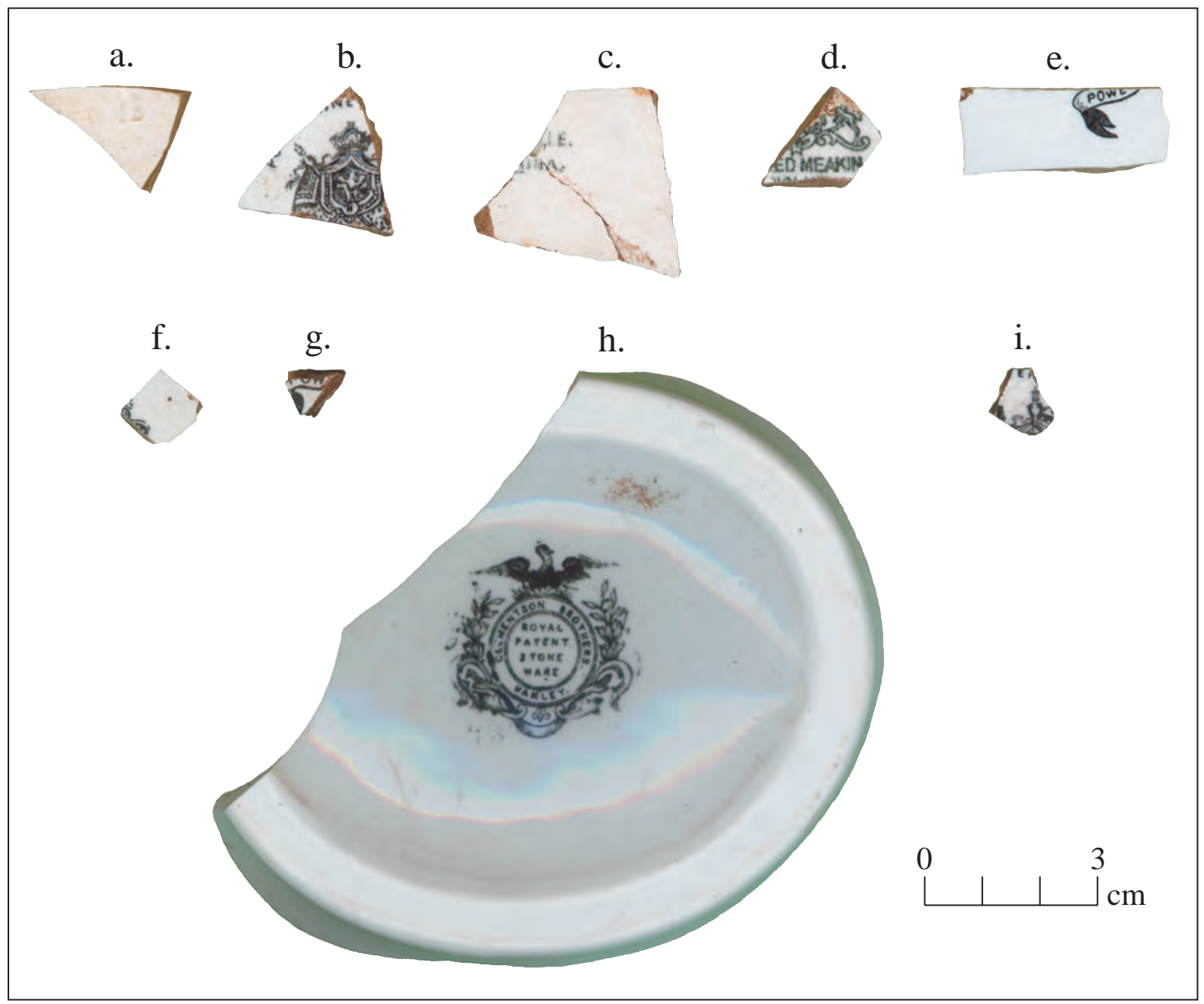

Figure 6-7. Ceramic maker’s marks: (a) unknown incised; (b) John Edwards \& Co; (c) La Belle China; (d) Alfred Meakin; (e) Powell \& Bishop; (f) unknown; (g) possible Powell \& Bishop; (h) Clementson Bros; (i) unknown. 
Table 6-2. Identified ceramic maker's marks from the Levi Jordan Plantation.

\begin{tabular}{|l|l|}
\hline & $\begin{array}{l}\text { Ceramic Type, Form, } \\
\text { and Manufacturer }\end{array}$ \\
& $\begin{array}{l}\text { Semi-porcelain pitcher } \\
\text { base } \\
\text { Clementson Brothers, } \\
\text { Phoenix and Bell Works } \\
\text { Shelton, Hanley, Stoke- } \\
\text { on-Trent, England } \\
\text { Mark used 1870-1916 } \\
\text { (Birks 2005) } \\
\text { Maker's Mark (CAS 2005) }\end{array}$ \\
\hline
\end{tabular}

Table 6-3. Unidentified ceramic maker's marks from the Levi Jordan Plantation.

\begin{tabular}{|l|l|}
\hline Maker's Mark & $\begin{array}{l}\text { Ceramic Type, Form, } \\
\text { and Manufacturer }\end{array}$ \\
\hline & $\begin{array}{l}\text { Ironstone base } \\
\text { Mark unknown } \\
\text { Maker's Mark (CAS } \\
\text { 2005) }\end{array}$ \\
\hline & $\begin{array}{l}\text { White earthenware base } \\
\text { Mark unknown } \\
\text { Makers Mark (CAS }\end{array}$ \\
\hline & $\begin{array}{l}\text { White earthenware base } \\
\text { Mark unknown } \\
\text { (incised) } \\
\text { Maker's Mark (CAS } \\
\text { 2005) }\end{array}$ \\
\hline
\end{tabular}

States (Barber 2001:11 [1904]). Only those who held a higher socioeconomic standing could afford to purchase imported English pottery (Miller 1980). Identified marks greatly aided in determining the manufacturer and date of the ceramic vessels they represented.

\section{Other Ceramics}

An additional 34 ceramic pieces were recovered that were not classified under the ceramic vessel categories discussed above. These include a German ceramic marble, a piece of a porcelain toy dish, a piece of a porcelain box base, a piece of a porcelain figurine, a fragment of a porcelain molded vase, part of a porcelain caster wheel, a fragment of a modern porcelain dish, 11 bisque figurine fragments, 4 pieces of a modern flower pot, and 12 pieces of clay skeet pigeons (Figure 6-8). 


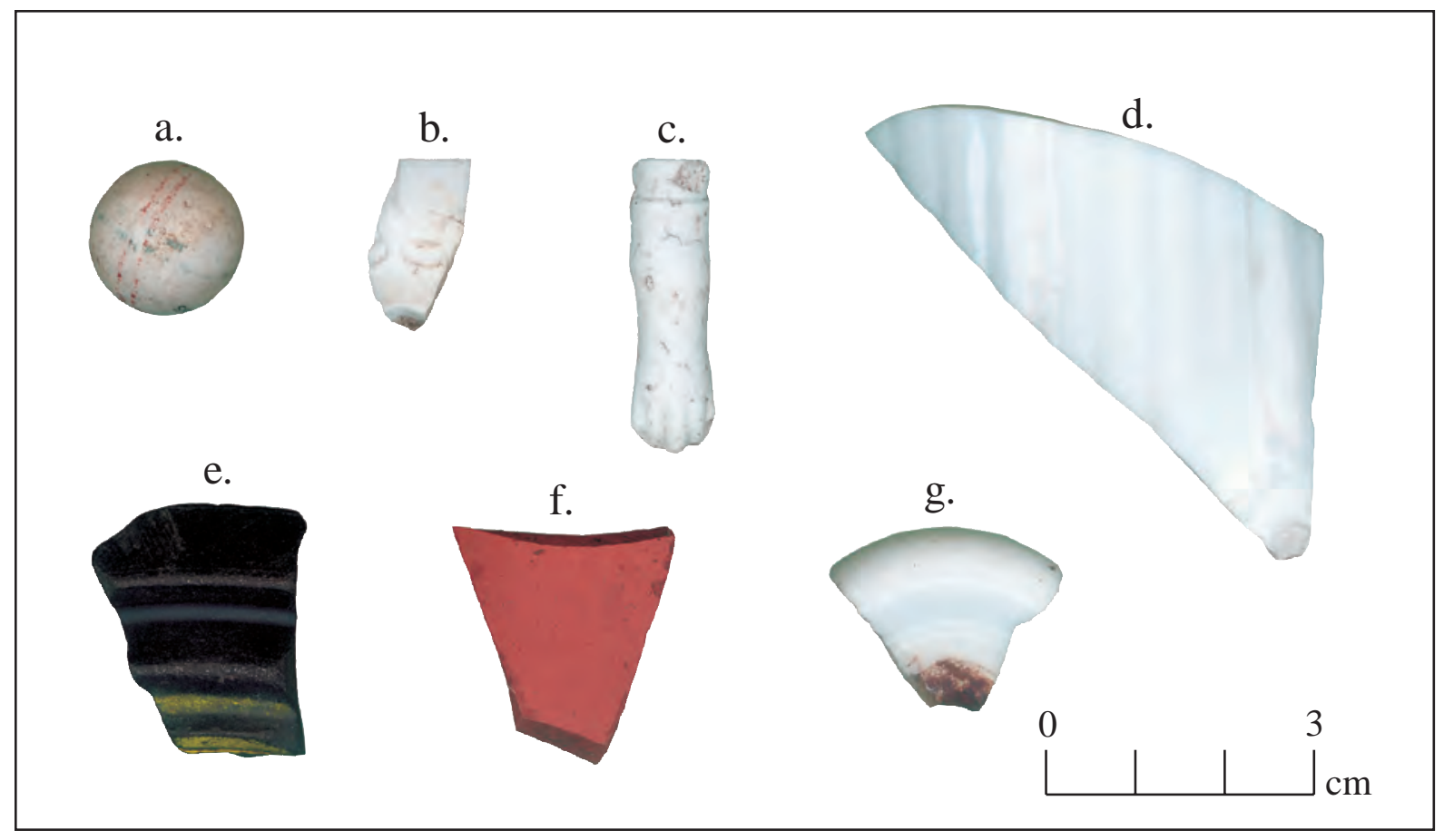

Figure 6-8. Other ceramics: (a) marble; (b,c) figurine fragments; (d) porcelain vase; (e) clay skeet; (f) terra cotta flower pot fragments; (g) porcelain caster fragment.

\section{Metal Artifacts}

\section{Nails}

Nails are frequently used in the construction of dwellings, buildings, barns, fences, and outbuildings; therefore, they have often been relied upon in the interpretation of historic sites. They enter the archaeological record through various means such as unintentional discard during construction, reuse and then discard, discard from loosening, and intentional discard during demolition (Jurney 1988). Once part of the archaeological record, they provide valuable information to the archaeologist concerning building chronology, dating of additions, changes, and maintenance. Nails are classified into three main types: hand-wrought, square-cut nails, and round wire nails (Nelson 1968).

Hand-wrought nails were the only nails available throughout the seventeenth century and into most of the eighteenth century; however, they were still utilized in the nineteenth century. The heads of these nails varied according to their use with the rose head the most common for general use. L-headed nails were generally used as flooring and trim nails, while the T-headed nail, consisting of a flat disc head, was generally used for flooring (Noël Hume 1969:252-254). Hand-wrought nails were in common use in the United States until the 1880s, when square-cut nails, introduced in the 1830s, became more popular (Nelson 1968). Once these nails were cheaply mass-produced, it was more cost effective to buy them in the nearby centers of commerce than to make them from hand.

The square-cut nail (Figure 6-9) is an American invention that was first produced circa 1790. These nails were sliced from sheet iron by machine, and their heads were individually shaped by hammering. By 1815 


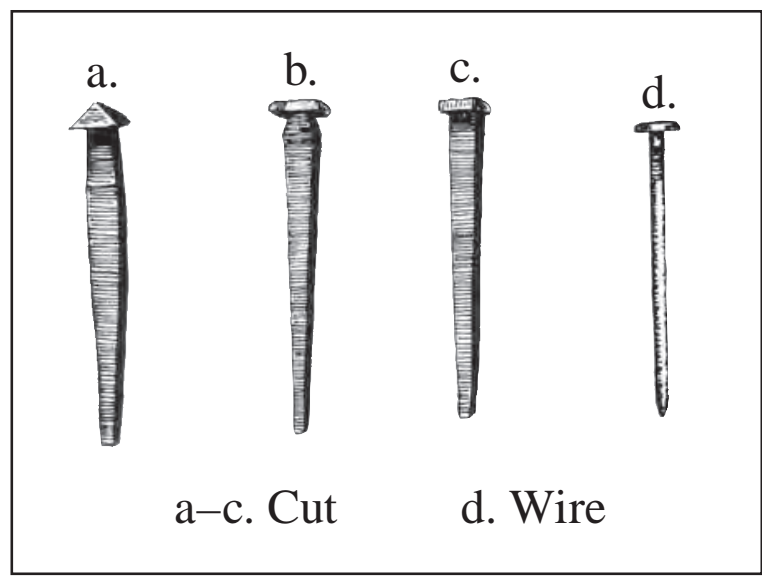

Figure 6-9. Square-cut and wire nails (adapted from Noël Hume 1969: Figure 81).

the heads of these nails were also made by machine, which changed their appearance. Square-cut nails manufactured prior to circa 1830 also had metal fibers that ran crosswise to the nail's length, distinguishing them from later square-cut nails that had metal fibers running lengthwise (Noël Hume 1969: 252254). Square-cut nails with hand-hammered heads were popular in the United States between 1790 and 1825. Their popularity was replaced by square-cut nails with machinemade heads in 1825, and use of this nail type continues to the present (Nelson 1968).

Europeans perfected a round-shafted, steelwire nail in the mid-nineteenth century and by the 1850 s, round-wire nail manufacturing had been established in New York (Noël Hume 1969:252-254). Though they were manufactured by the early 1850s, round-wire nails did not become popular until the 1890s. While wire nails are the most popular nail used today, square-cut nails also continue to be used for flooring, boat carpentry, and masonry needs (Nelson 1968).

Six hundred and eleven identifiable nails were recovered from excavation units within or near the main plantation house. Of these nails, 188 (31 percent) were square-cut nails that were in use from circa 1790 to 1890 . Four hundred and twenty-three (69 percent) of the recovered nails were round-wire nails that were in popular use from the mid- to late nineteenth century through the present. These dates are supportive of a nineteenth-century occupation of the Levi Jordan Plantation, and are further supported by historical documentation and analyzed artifact assemblages.

\section{Munitions}

While no firearm pieces were recovered during excavations, there were a number of munitions fragments (Figure 6-10). These fragments were identified as to date and manufacturer when possible. Five buckshot fragments, five bullets, eleven center fire casings, two rim fire casings, ten shotgun shell bases, and one percussion cap were collected during excavations. Their associated manufacturers and date of manufacturing are presented in Table 6-4.

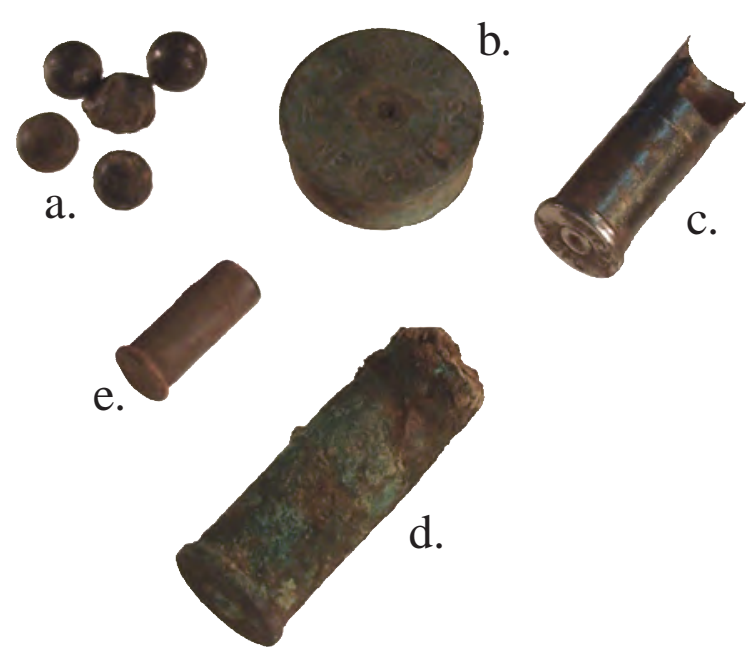

Figure 6-10 Munitions: (a) lead buckshot; (b) brass 12-gauge shotgun shell base with "U.M.C. Co. New Club” headstamp; (c) .38 caliber Peters Special steel center fire bullet casing; (d) .45 caliber brass center fire casing; (e) .22 caliber brass center fire casing. 
Table 6-4. Identified munitions headstamps from the Levi Jordan Plantation.

\begin{tabular}{|l|l|}
\hline & Munitions, Manufacturer \\
Center fire bullet casing \\
Peters Cartridge Company \\
Kings Mills, Ohio \\
Headstamp used 1887-1934 \\
(University of Utah, \\
Department of \\
Anthropology 1992:2) \\
Headstamp (CAS 2005)
\end{tabular}

\section{Coins}

Four coins were collected during excavations at the main plantation house. These include two Lincoln Memorial pennies, one Buffalo nickel, and one Liberty Head nickel. The Liberty Head nickel was minted between 1883 and 1913 (Figure 6-11). It contained the Liberty head on one side and a Roman numeral V on the reverse. The first minted coins contained a flaw; they lacked the word "cents" under the V on the reverse side. As a result, unscrupulous individuals plated the

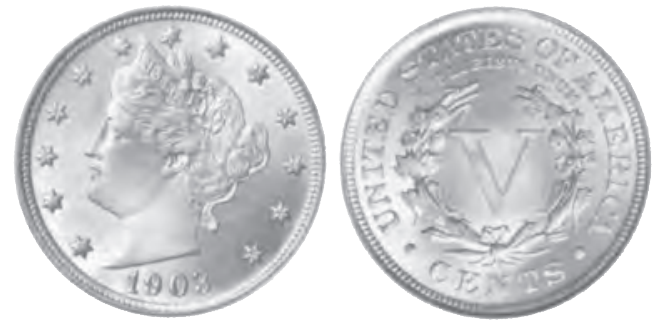

Figure 6-11. Example of a 1903 Liberty Head nickel (Bressett 2005: color plate).

coins with gold and passed them off as \$5 gold pieces. This flaw was quickly remedied, but by then at least 5.5 million of these coins had been minted (Breen 1988). The Liberty Head nickel collected during excavations is dated 1883. An examination of the reverse side showed the word “cents” below the Roman numeral V.

The Buffalo nickel, or Indian Head nickel, was first minted in 1913 (Figure 6-12). This was the first coin to feature an animal other than an eagle. These coins contained 75 percent copper and 25 percent nickel. It was produced from 1913 until 1938 (de Resendes 2005). The Buffalo nickel recovered during excavations has a date of 1924.
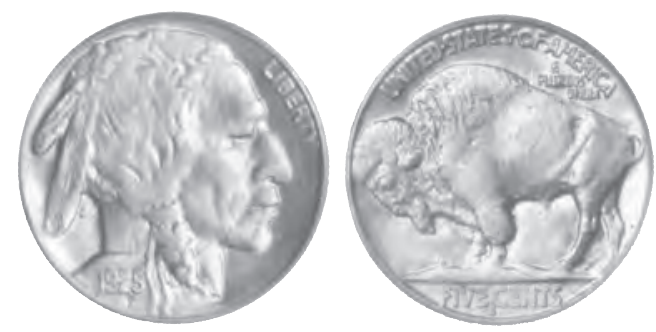

Figure 6-12. Example of a 1925 Buffalo/Indian Head nickel (Bressett 2005: color plate).

The one cent coin, the penny, was the first currency type authorized for production in the United States in 1787. Abraham Lincoln was the first historical figure to be minted on a US coin. This was done in 1909 as a celebration of the one hundredth anniversary of his birth. In 1959, 
the Lincoln Memorial was added to the reverse side of the coin (Figure 6-13) in celebration of the one hundred and fiftieth anniversary of his birth (Americans for Common Cents 2005). One of the two pennies collected during excavations has a date of 1970; the other's date is indistinguishable due to corrosion.
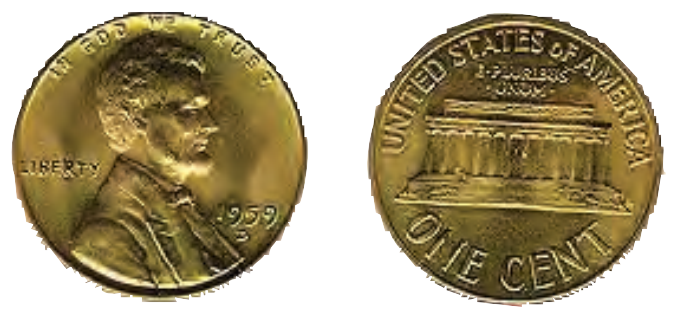

Figure 6-13. Example of a 1959 Lincoln Memorial penny (Americans for Common Cents 2005)

\section{Bricks}

Due to the overwhelming amounts of brick encountered during excavation, a brief discussion on handmade bricks and their manufacturing process is warranted. A total of 1,133 bricks or brick fragments were collected during excavations; however, this only represents a fraction (less than 10 percent) of the numbers of bricks encountered. Despite the fact that bricks are found in abundance at historical sites, archaeologists have long overlooked them as an artifact class (Gurcke 1987:1). As bricks do have diagnostic features, they therefore should be examined and included in artifact discussions (Gurcke 1987:1-2).

Bricks are manufactured through a fivestep process: winning, preparation, molding, drying, and firing. Winning is the mining of the raw material used in the manufacturing of bricks. The next step in brick making involves preparing the clay by weathering and tempering. The clay is molded into a shape that resembles the final product, and then thoroughly dried before being fired (Gurcke 1987:3-38).

Bricks were predominately made by hand until the late eighteenth century. Brick making machines began to appear by the midnineteenth century, and by the beginning of the twentieth century the entire process of brick manufacturing, from mining clay to removing bricks from kilns, had been mechanized (Gurke 1987:84). However, the bricks recovered during excavations at the Levi Jordan Plantation were handmade. Handmade bricks are manufactured from clay with a water content between 20 and 30 percent. The clay is then molded in wooden or iron clad molds (Gurke 1987:15). Sand, water, oil, lard, or even soap is then used as a lubricant to allow the molded brick to slip free of its mold. Handmade bricks require up to three weeks for drying, depending upon water content of the clay and the weather and humidity levels (Gurke 1987:26). Handmade bricks are distinguishable from machine-made bricks in that handmade bricks display greater variation in size and shape, and often weigh more than machinemade bricks (Gurke 1987:106).

Of the 1,133 brick and brick fragments collected, 53 were glazed or have traces of glazing. Glazed or enamel bricks are commonly used in the construction of rest rooms, showers, kitchens, or other areas that require frequent cleaning or will be wet for long periods of time. Occasionally glazed bricks are used on exteriors for decorative purposes. In order to create a glazed brick, a layer of glaze is applied to the brick over a colored or white slip. This glaze can be applied either before or after drying. Following this process the brick is then fired. Enameled bricks are created by applying a glaze to a brick without an intermediate slip; the glaze itself contains the coloring (Gurke 1987:100). 
The glaze on the glazed brick and brick fragments recovered during excavation appears to be a thin salt glaze. This is more likely to have resulted from excessive heat than from intentional glazing. It has been noted that salt has been historically used to clean out the builtup residue in chimneys (Carnes-McNaughton 1998). This results in the deposit of a thin salt glaze on the interior bricks of the chimney hearth. However, a salt glazing could have formed on bricks during the brick making process. Due to the coastal location of the Levi Jordan Plantation, a high concentration of salt is present in the soil and ground water in the area. As the handmade bricks used in the construction of the plantations buildings were fired, salt water condensation would have turned to salt glaze on those bricks that were closest to the heat source, and thus over-fired. The fact that the recovered glazed bricks and brick fragments were collected from areas not requiring glazed bricks suggests that they were the result of over-firing.

\section{Buttons}

The nineteenth century marked a technological change in the manufacturing of buttons that allowed for the inclusion of more varieties of materials, and more variation of styles (Epstein and Safro 1991:76). Shell buttons, which had been made by hand, were now mass produced through machine methods. By 1870, the synthetic plastic celluloid was introduced and utilized in button manufacture, replacing bone, ivory, tortoiseshell, and marble materials (Epstein and Safro 1991:78). The rich and colorful buttons of the eighteenth century were replaced by small glass or jeweled buttons on men's fashions. Buttons for women, however, became more ostentatious, resembling brooches and decorative jewels. These buttons were manufactured from porcelain, pearls, and silver (Epstein and Safro 1991:80). Most buttons, however, were of a utilitarian nature. While the Sears Roebuck catalog for 1897 included two styles of fancy dress button, most of their buttons were intended for practical use. These included plain metal buttons for pant flies, bone buttons for underwear, and plain shell buttons that were sold by the gross (Israel 1968:319-320).

During excavations at the main plantation house, fourteen buttons were collected (Figure 6-14): three glass (Figure 6-14c-f), five metal (Figure 6-14j-m), three plastic (Figure 6$14 \mathrm{~g}-\mathrm{i}$ ), one porcelain (Figure 6-14b), and one shell (Figure 6-14a). The three glass buttons collected were of a white, opaque color, and two of the three were flat with four holes. The third button is a half-sphere shape with a loop shank and a molded, basketweave design. The white or opaque buttons were likely used on men's garments, while the decorated half sphere probably appeared on a piece of women's clothing. White opaque buttons of this type are the exception to the rule, as most glass buttons of the nineteenth century were jet black buttons. These jet black buttons came into fashion following the death of Prince Albert, Queen Victoria's husband, and continued in popularity until World War I (Whittemore 1992:15).

The metal buttons collected during excavations were badly corroded, and details of their design and construction were not identifiable. Two of these buttons had loop shanks, while the rest were flat, most likely with two to four holes. Metal buttons are typical of buttons on work clothes.

Three plastic buttons were collected, and as mentioned above, celluloid, an early form of plastic, was first produced in 1870 . However, it was not used for button manufacture until after World War I. Two of the three buttons were flat and had four holes, while the third, 


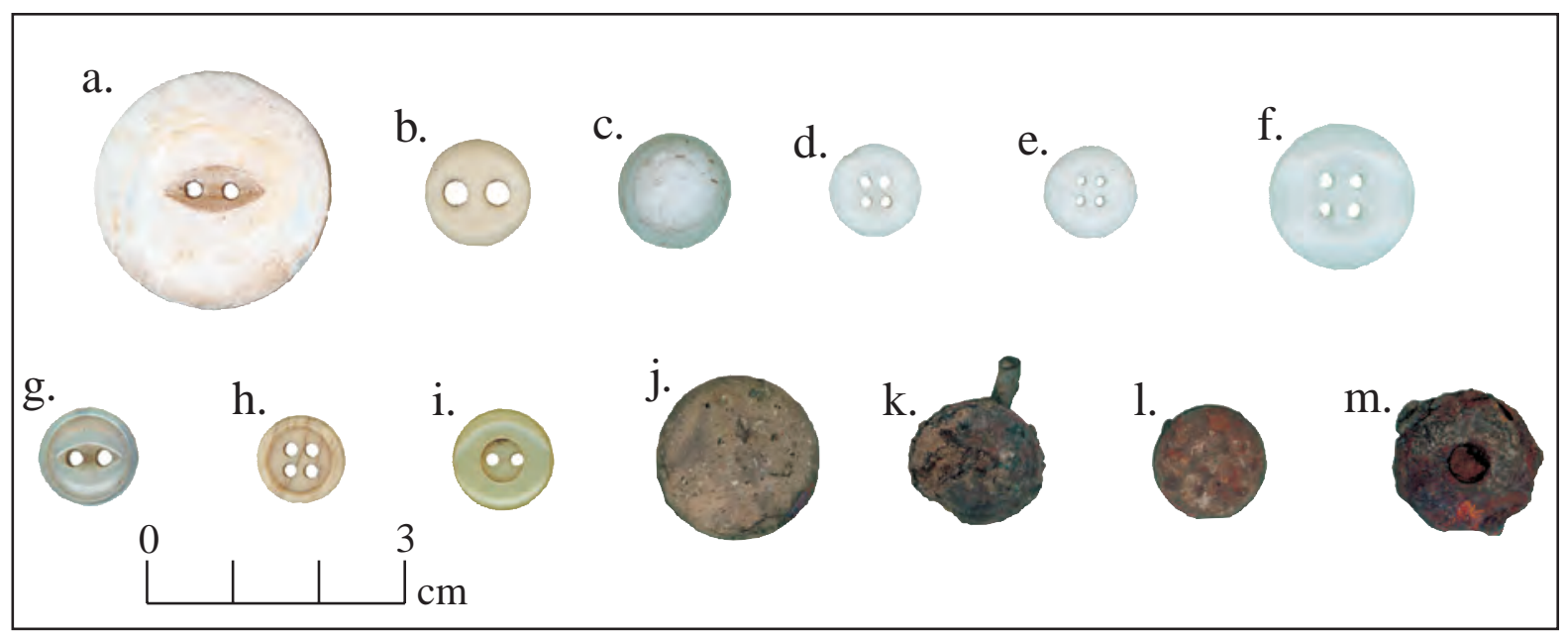

Figure 6-14. Buttons: (a) shell, 2-hole flat; (b) porcelain, 2-hole flat; (c) glass, 1/2 sphere, loop shank, basketweave pattern; $(\mathrm{d}, \mathrm{f})$ glass, 4-hole flat; (g) plastic, 2-hole flat; (h) plastic, 4-hole flat; (i) plastic, 2-hole flat; (j) lead, loop shank; (k) iron, loop shank; (l) brass, straight shank, with illegible lettering; (m) metal button back.

a flat button, had two holes. These buttons were most likely used on men's clothing or on women's undergarments.

Porcelain, or china, buttons are often misidentified within archaeological literature as milk glass buttons. They were first manufactured in the United States in 1848 by Charles Cartlidge of Greenspoint, Long Island; however, the majority of porcelain buttons of this time period were imported from France (Poole 1982:281). The single porcelain button collected was of a flat, two-hole construction most likely came from a man's garment.

Shell buttons are non-iridescent buttons manufactured from freshwater shells. The freshwater pearl industry was introduced to America by John Boepple, a German immigrant, who discovered freshwater mussels near Muscatine, Iowa. By 1890, high import taxes forced reliance upon domestic sources of shell buttons, and Iowa was the main producer with over 200 button factories by the turn of the century. Shell buttons in the United States were manufactured for utilitarian use as fasteners for shirts, underwear, and children's clothing. The most common type was the "sew-through type," which was eventually replaced by cheaper and stronger buttons made from plastic (Poole 1982:283). The single shell button collected during excavations is of the flat, two-hole variety. Shell buttons were used a fasteners for children's clothing, underwear and shirts. 


\section{Chapter 7}

\section{INTERPRETATIONS, CONCLUSIONS, AND RECOMMENDATIONS}

The Levi Jordan Plantation, now a State Historic Site, was established by Levi Jordan in 1848. At its height, this antebellum sugar and cotton plantation sat on more than 2,000 acres of rich river bottomlands on the Gulf Coastal Plains of Brazoria County, Texas. Artifacts recovered during limited excavations at the main house support an occupation that extends from the antebellum period through the end of the twentieth century. Numerous ceramic sherds, glass shards, munitions, handmade brick fragments, coins, buttons, and nails represent occupation of the main plantation house between the 1840s and 1990s. Between 1986 and 2002, the plantation had been the subject of archaeological investigations conducted by the University of Houston. However, these investigations were limited to the area of the slave and tenant quarters. The current Center for Archaeological Studies investigations have focused on the main plantation house and areas to be developed for public access.

The Texas Parks and Wildlife Department is gathering archaeological data from the current archaeological investigation in order to address questions on the historical development of the main house and site. This data will be utilized for long-term stewardship, interpretation, and management of these resources. Archaeological investigations were conducted in areas of interest designated by TPWD and labeled Zone A, Zone B, Zone C, Zone D, Zone E, Zone G, and Zone Z.

\section{Interpretations}

\section{Zone A}

Zone A encompasses the gallery room at the rear-center of the house. TPWD speculates that a porch or portico was built over this area sometime after the construction of the original plantation house. This porch or portico was later modified into the current rear gallery room. Remains of a brick walkway are located beneath the floorboards of this room and indicate that a back door exit existed here at one time and was initially the rear door of the house. The presence of the brick walkway suggests that persons were able to exit the back of the house and followed a brick path that might have extended further into the backyard, possibly to a detached kitchen building. Brick remains on either side of this brick walkway also suggest extensions to the east and west.

Excavations of test units in this zone provide evidence for the propositions mentioned above. Excavation in Units A1 and A2 uncovered features that point to the existence of a brick walkway that extended to the north of the house, further into the backyard (Figure 7-1). The feature located in Unit A2 also indicates that an additional walkway extended from the northeast of the back door exit to the original rear wing extension. The lack of features in conjunction with a large quantity of artifacts suggests that Unit A3 was the location of a sheet midden. This further supports the 


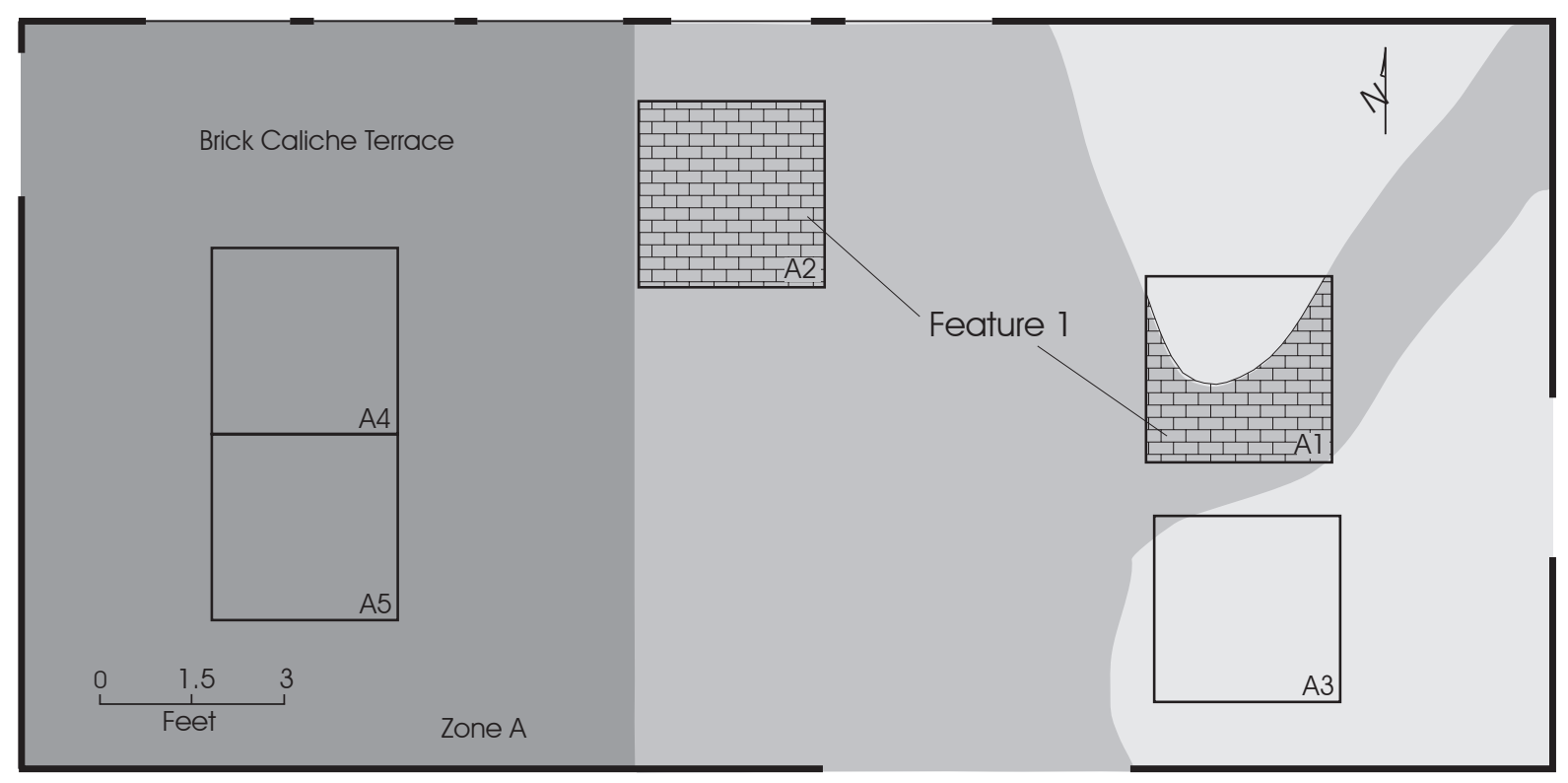

Figure 7-1. Illustration of Zone A indicating locations of units, Feature 1, and possible extent of original brick walkways and terraces.

location of a brick walkway in Units A1 and A2, as debris was most likely swept off of the brick walkway and accumulated in the corner where Unit A3 is located. The excavation of Units A4 and A5 confirms the theory that a terrace was constructed in this area and was later covered by the porch or portico, which then modified into the rear gallery room. The hard compacted brick caliché mix encountered in this unit probably served as a foundation for the original terrace.

Analysis of artifacts recovered from excavation units in this zone provided data on activities, occupation dates, and construction dates. The recovery of domestic items such as faunal remains, organic remains, textiles, ceramic sherds, and glass bottle, jar, and tableware fragments indicate domestic activities that occurred between the 1850s and the 1950s. The majority of ceramics recovered from units in this zone were English white earthenwares manufactured between 1850 and 1895. A fragment of an English white earthenware recovered from Unit A3 had a maker's mark by Powell and Bishop and was manufactured in England between 1867 and 1878. A silver plated spoon was also recovered from Unit A1 and has been manufactured by the Rogers Brothers from 1951 through the present. Fragments of chimney glass resembling chimneys manufactured by the Phoenix Glass Company in 1897 were collected from Units A2 and A5. A fragment of a glass thermometer was also recovered in this zone from Unit A2.

Evidence of recreational activities were also suggested in Unit A1 by the recovery of a slate chalkboard fragment and a German ceramic marble that dates to the mid-nineteenth century. The recovery of a Liberty Head Nickel with a date of 1883 from Unit A1 provides additional support to an occupational history that extends between 1850 and 1950 .

An examination of identified nails recovered from units in Zone A suggest major construction in this zone occurred sometime after 1890. Ninety-two percent of the identifiable nails were round nails that were in 
common use by the 1890s. This may have been the date during which the porch or portico was constructed over the terrace and attached to the rear of the house. The date of the terrace's construction, and whether this was a temporary construction used until a porch or the rear gallery room was constructed, is unknown.

An examination of the distribution of window glass dates for this zone indicates the greatest peak at 1891 ( \pm 7 years) (Appendix A Figure A-2). Based on Moir’s (1987, 1988) argument that the dating of window glass fragments suggests construction dates, it can be inferred that in 1891 ( \pm 7 years) there was an episode of significant construction in this zone. This may have been when the porch/ gallery room was constructed and attached to the main house.

\section{Zone B}

Zone $\mathrm{B}$ is located in the current rear wing extension. Excavations in this zone focused on the recovery of data associated with the brick foundation of the fireplace located under the floorboards. The current wing is an early twentieth-century addition that replaced the previous wing, which was destroyed by a hurricane (Freeman 2003:134). Initial investigations by TPWD indicated that the fireplace faced south, toward the original house.

Units were excavated on opposing corners of this fireplace foundation in order to investigate the possible location of the original outer wall, as well as construction details of the brick chimney. The discovery of a soil color change in the second level of Unit B2 indicates the location of the original wall of the rear wing (Figure 7-2). The darker soil located in the northern half of this unit is characteristic of soil that has been exposed to weathering elements, while the lighter soil in the southern half of the unit is indicative of soil that was not exposed to weathering element; it was most likely covered by the original rear wing. The original northern wall of this wing appears to have extended in an east to west direction, in line with and parallel to the chimney foundation (Figure 7-3).

Additional evidence to support this proposition is provided by a comparison of window glass for Zone $\mathrm{B}$. Zones $\mathrm{A}$ and $\mathrm{B}$ contained far less window glass than Zones $\mathrm{C}$, $\mathrm{D}$, and $\mathrm{E}$. It is known that Zones $\mathrm{A}$ and $\mathrm{B}$ have been covered by the house or additions for all

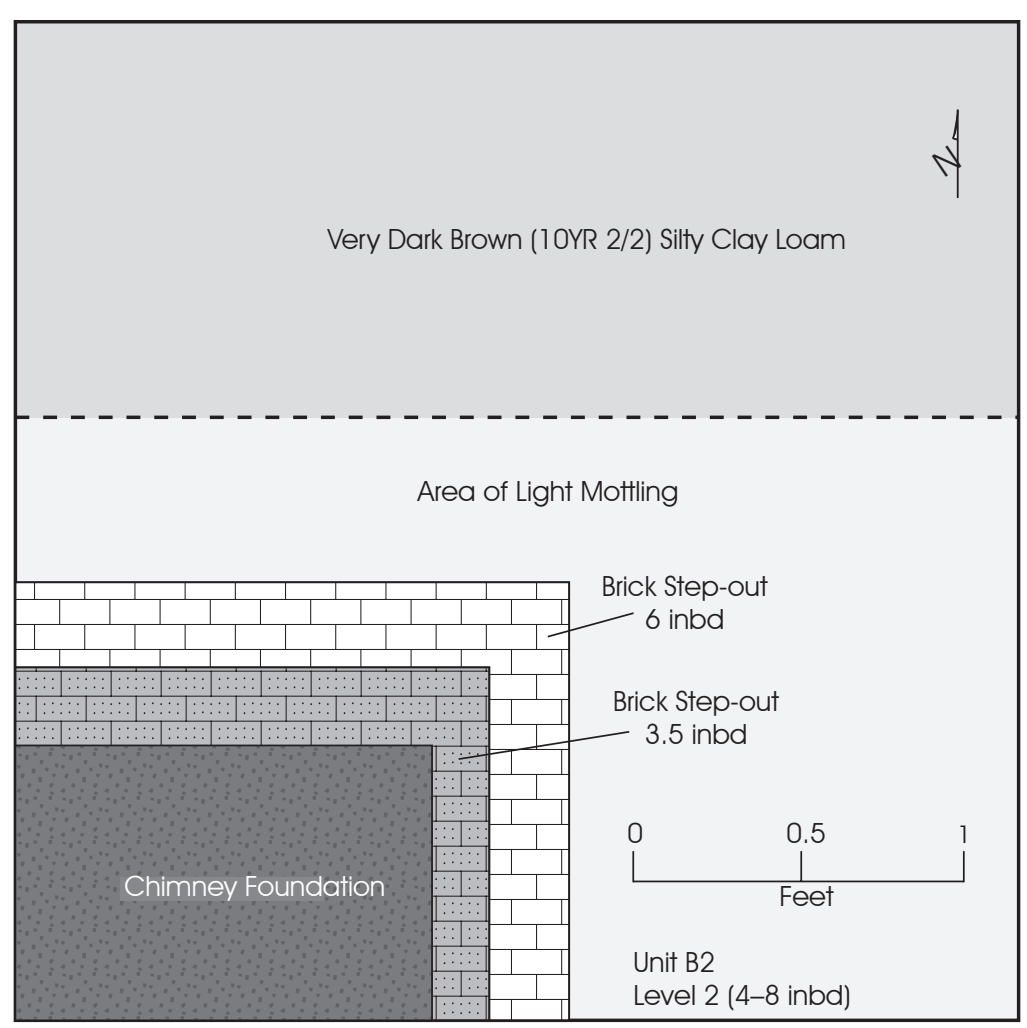

Figure 7-2. Illustration of Unit B2 level 2 (4-8 inbd). 


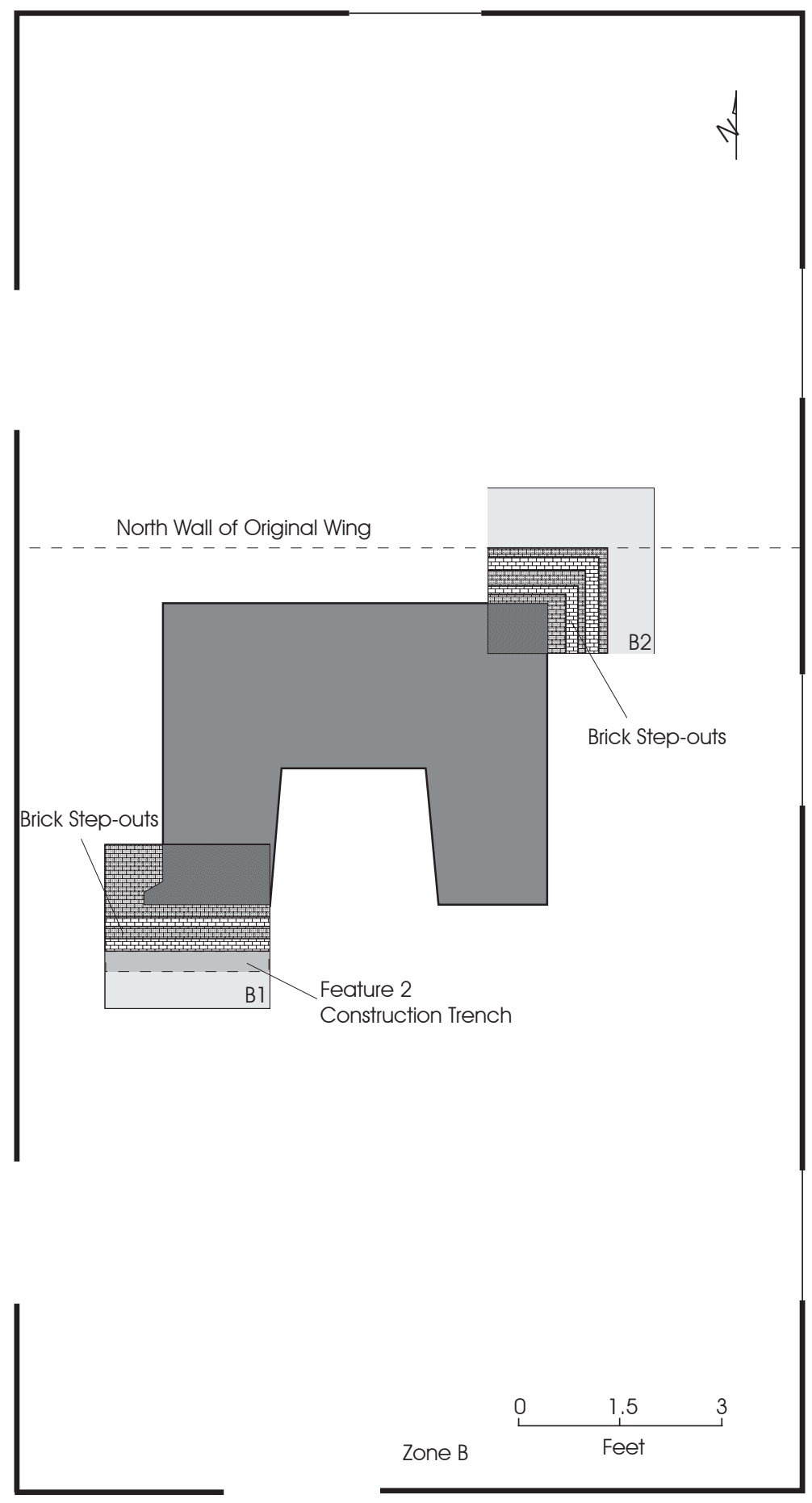

Figure 7-3. Illustration of Zone B showing brick step-outs and north wall of the original wing.

or most of the house's occupation period, which would prevent broken window glass from being deposited in the area of these units. Zones C, D, and $\mathrm{E}$, however, have remained uncovered for all or most of the occupation, and were therefore most susceptible to window glass accumulation. That uncovered units contain more window glass than covered units is amply illustrated in Appendix A Figures A-2 through A6. This logic can assist in determining both the placement of the original rear wall and the timing of the reconstruction. Unit B2 contained far more window glass than Unit B1 (Appendix A Figures A-13 and A-14), indicating that at some point Unit B2 was exposed. The soil change observed in B2 indicates how much of $\mathrm{B} 2$ was exposed by the placement of the original north wall.

The time of reconstruction can be determined by the temporal distribution of the window glass. The greatest peaks in distribution in Unit B2 are prior to 1900 , the year the original rear wing was destroyed and replaced. This suggests that after 1900 the area was covered by a rear wing extension, supported by a significant drop in window glass amounts (see Appendix A Figure A-13).

Units B1 and B2 also provide data on the construction of historic chimney foundations. Excavations of these units indicate that a construction trench was created where the fireplace foundation was to be built. This was followed by the placement of five foundation 


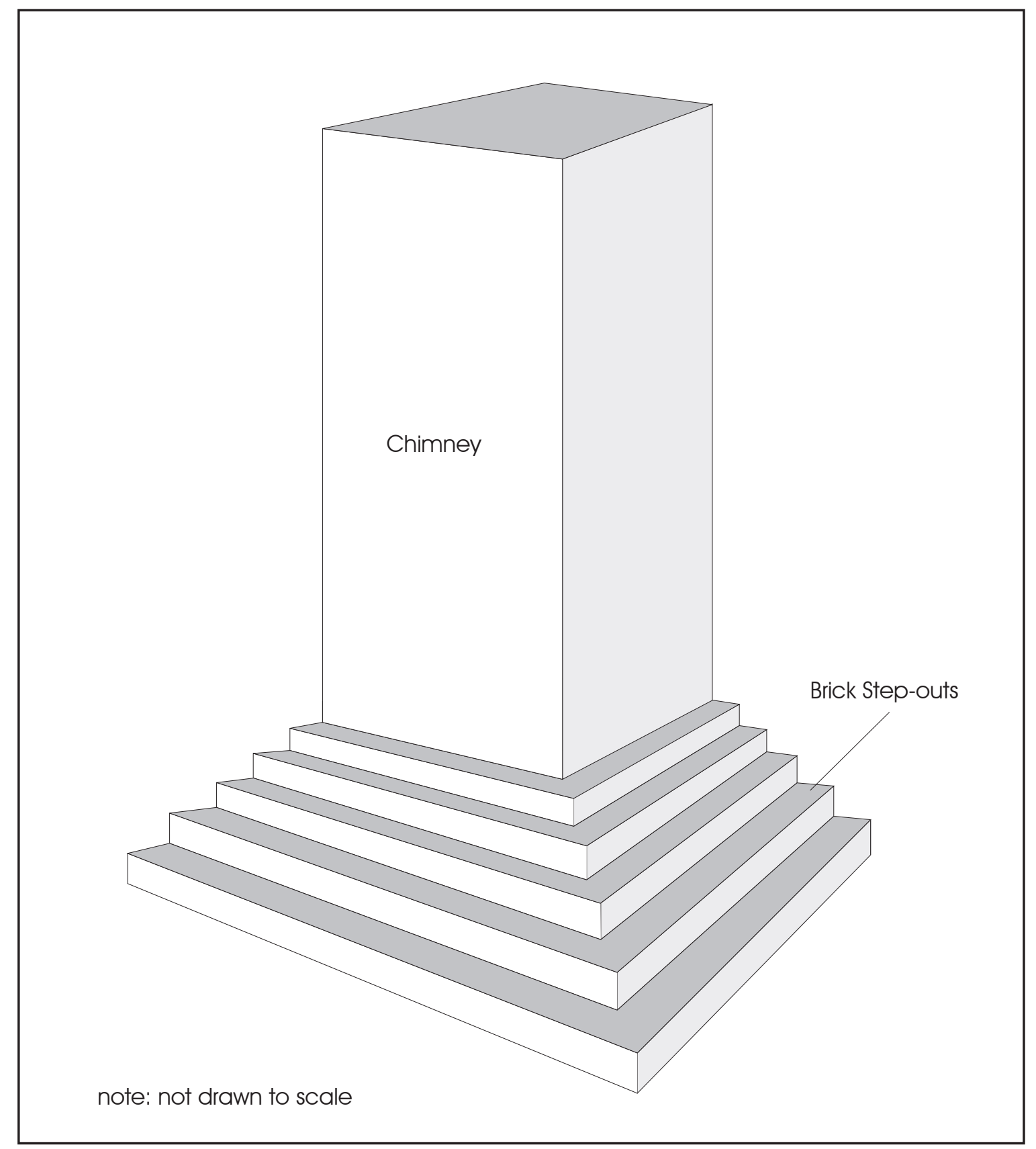

Figure 7-4. Diagram of chimney construction.

brick step-outs to ring the base of the original chimney in a pyramid-like fashion (Figure 74). This appears to have functioned as a means of support and stability for this feature. The discovery of a construction trench surrounding thesebrickstep-outcoursesfurtherdemonstrates that the chimney was first constructed below ground level, rising up in a pyramid-like shape to form the hearth and base of the chimney at ground level. This would provide support and stability to a structure that may have stood over two stories tall.

Domestic activities are indicated by the recovery of faunal remains, organic remains, ceramic sherds, glass shards, and textiles. The 


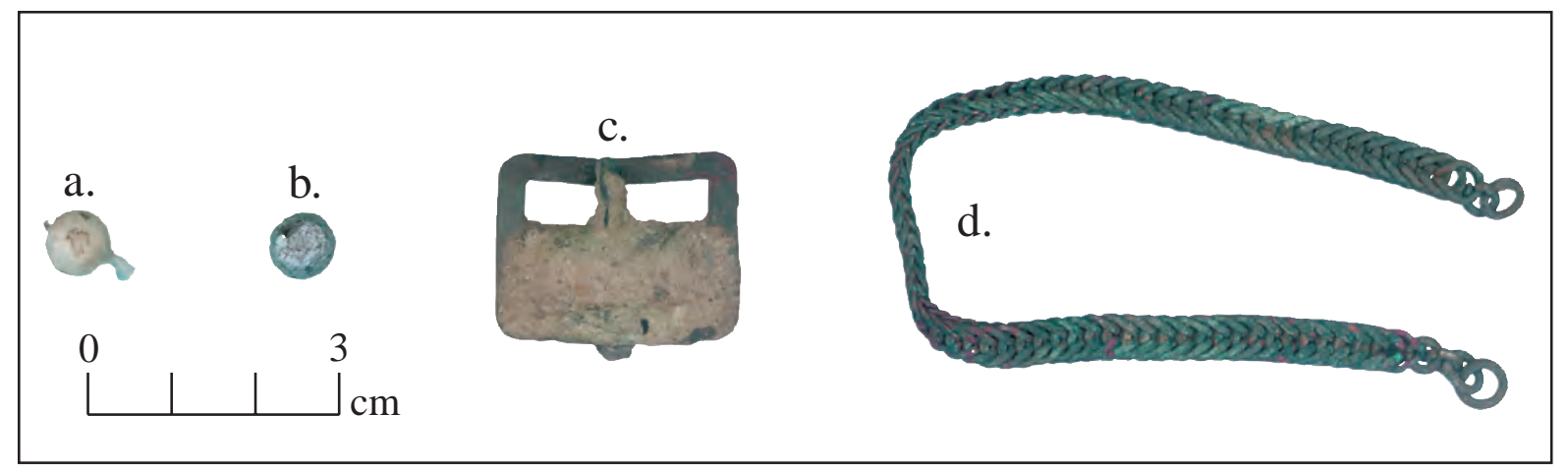

Figure 7-5. Personal items: (a) pearl bead on string; (b) aluminum bead; (c) buckle; (e) copper bracelet.

presence of a pie tin, a fragment of a drinking glass, and a glass lid liner from a mason jar imply eating and or cooking activities in this zone. The retrieval of a metal bracelet from Unit B1 is indicative of some of the personal items recovered during excavations (Figure 7-5d). Occupation dates between 1850 and 1970 are supported by the analysis of artifacts from this zone. The majority of these datable artifacts consist of English white wares with representations of ironstone and semi-porcelain. Construction dates correlate with these occupation dates and are supported by the dating of window glass, as well as the presence of round nails manufactured beginning in the late 1880s.

\section{Zone C}

The two excavation units of Zone $\mathrm{C}$ were placed along the standing east chimney of the main house to expose the chimney foundation. Data gathered from these excavations provided information concerning construction, weightbearing strata, and the condition of this historic structure. The assessment of the stability of the standing chimneys is important because the house is currently sagging around the chimneys. This information will provide data necessary in the evaluation of the house's current structural condition. Construction details were also compared to those observed in the chimney foundation in Zone B.
The same construction details observed in Zone B were evident in the chimney foundation of Zone C (Figure 7-6). A construction trench was located around the chimney foundation, allowing for below-ground-level construction

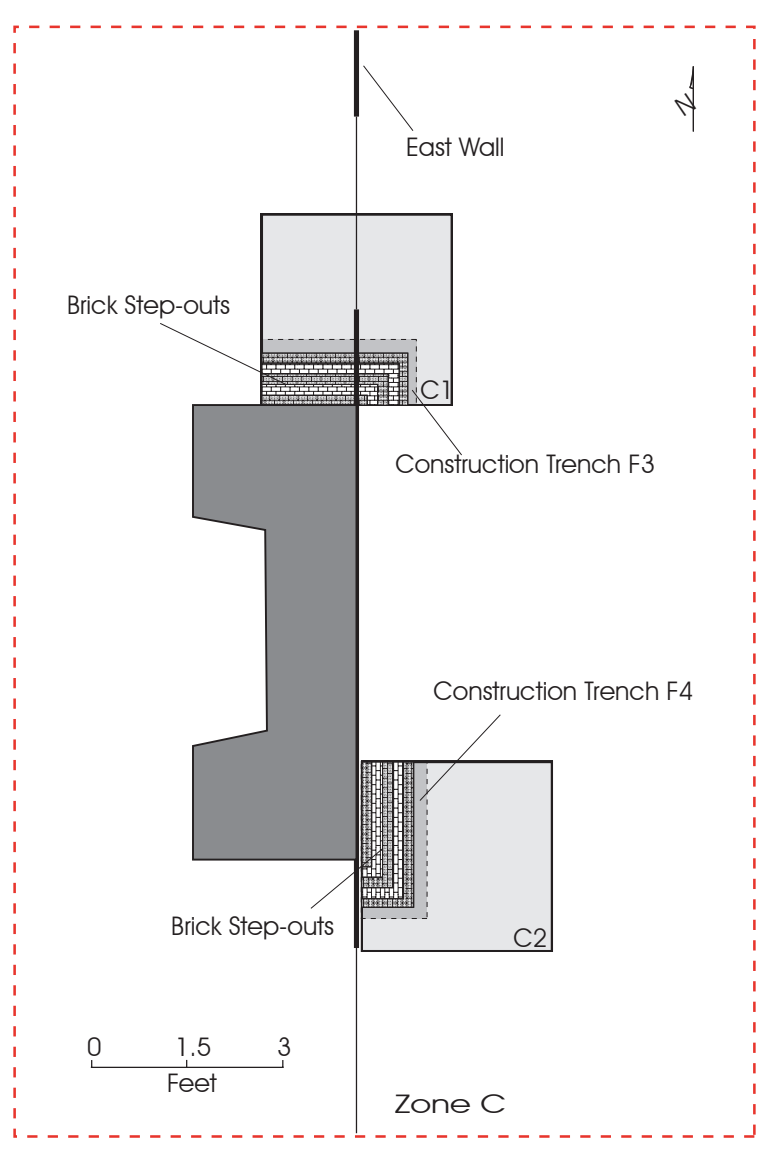

Figure 7-6. Illustration of Zone $\mathrm{C}$ indicating the locations of units, Features 3 and 4, and the similar construction of the chimney. 
of stabilizing courses of brick step-outs. Like the foundation in Zone B, Zone C's chimney foundation rises up in a pyramidal shape to ground level through a course of five brick stepouts (see Figure 7-4). This also provides support and stability for a chimney that is over two stories tall. The effectiveness of this method is clearly seen by the current condition of the house. According to recent engineering studies (Michael Strutt, personal communication 2005), the chimneys are rising, causing the structural sagging of the house frame at the corners. The identical construction of the chimney foundation in Zone $\mathrm{C}$ to that of the foundation in Zone $\mathrm{B}$ suggests both features were constructed at the same time.

Artifact counts increased greatly in this zone, as it lies partially on the outside of the building. Recovered artifact materials include architectural materials, faunal remains, organic remains, bottle and chimney glass fragments, window glass shards, ceramic sherds, metal hardware fragments, personal items, and textile fragments. This area contained the largest concentration of faunal remains and organic materials. Like the previously discussed zones, Zone C also contains ceramics dated between 1850 and 1895. CAS collected two 12-gauge shotgun shells manufactured by the Union Metallic Cartridge Company between 1867 and 1902. A few pieces of identifiable and datable glass bottle fragments were also recovered. These included a piece of modern 1960s (or later) Coke bottle, a brown liquor bottle bearing a Federal Liquor Law embossing (dating this piece between 1932 and 1964), and the base and body of a panel bottle manufactured by the Illinois Glass Company between 1900 and 1916. Two fragments of Lacy Glass, most likely from a salt or candy dish, were representative of those manufactured during the 1840s. Additional items of interest include plastic toy fragments and the wheel from a toy bike. A buckle (Figure 7-5c), buttons, and a pearl bead (Figure 7-5a) were also uncovered during Zone $\mathrm{C}$ excavations. A single fragment of a colonial ware vessel was recovered from Unit C2. These artifacts attest to the long occupation of this site from its initial construction until the mid-1990s, as well as occupant possession of materials that predate original settlement.

Window glass recovered from Units $\mathrm{C} 1$ and C2 lend further support to the contention that window glass amounts display whether an area was exposed or covered by a structure. In the case of the Zone C units, Unit C1 was partially covered by the main house structure, whereas Unit C2 was completely exposed. This can be discerned through an examination of the GSI, which represented window glass amounts in each unit. Unit C1 had a GSI of 6.672, less than that of Unit C2, which had a GSI of 9.0369. Additionally, the dating of this window glass fell between the ranges of reported construction sequences of the main plantation house.

\section{Zone D}

Zone D is located in the southwest area of the front porch. A concrete porch replaced a wooden porch, thought to have once extended the full width of the main house, sometime in the twentieth century. The actual location of the original wooden porch is unknown. TPWD speculates its location to be similar to that of the modern concrete porch. Two excavation units were placed in this area to recover data concerning the original porch.

Unit D1 did not provide any information concerning the original porch or any associated features. The construction of the concrete porch in this location removed any features and or data that could provide information on the original porch. However, a brick walkway 
feature was uncovered in Unit D2 that extended in a westerly direction. This could be evidence of the original wooden porch's location, as this feature possibly served as a step-down and path away from the porch. Additionally, a handmade brick pier foundation was also uncovered in the northeastern profile of Unit D2 beneath the current pier support. This foundation was probably the support for the original piers, and its existence provides additional data on the construction of the original house.

An examination of window glass amounts points to the possible location of the southeast corner of the original porch (Appendix A Figures A-17 and A-18). A comparison of window glass amount from Units D1 and D2 distinctly shows a greater amount present in D2. This suggests that Unit D1 was covered by a porch and protected from the scattering of broken window glass.

Zone $\mathrm{D}$ is located on the outside of the main house, and a large number of artifacts were recovered from excavations. This zone contained the largest quantities of ceramic artifacts (38 percent of all ceramic sherds recovered) with over 70 percent of all ceramic sherds from Zone D located in Unit D2. The majority of these ceramics were identified as white earthenware, followed by ironstone, and then porcelain. White earthenware and ironstone ceramics collected from this zone were manufactured between 1850 and 1895, and the porcelain ceramics between 1830 and 1900. Of interesting note is a large fragment of a red transferware soup tureen lid recovered from Unit D1 that was possibly manufactured between 1830 and 1840 (see Figure 6-3i). These manufacturing dates correspond with occupational dates of the main plantation house. Additional datable artifacts from this zone include a .38 caliber bullet manufactured by the Peters Cartridge Company between 1887 and 1934.

\section{Zone E}

This zone is located on the eastern side of the main plantation house (see Figure 4-1). Excavation units were placed in this area to gather data concerning the possible location of an eastern porch and to determine the dimensions of the original rear wing extension.

Although Unit E1 was located in an area of high probability for features associated with an eastern porch, excavation of this unit did not uncover any such features or soil color changes. Nevertheless, this unit produced the greatest quantities of artifacts recovered during excavations at the Levi Jordan Plantation, suggesting that this area was once used as a trash dump.

Unit E2 was placed in a high probability location for features associated with the location and construction of the original rear wing (Figure 7-7). A tremendous amount of broken handmade bricks was encountered during excavations of this unit. Their presence most likely resulted from the collapse of the chimney from the original rear wing extension, which made it difficult to identify any features and or soil changes. However, a soil color change was encountered at a depth of 16 inbd. This feature was located in the southeast corner of the unit, approximately 19 inches away from the current rear wing extension. It is possible that this feature is the remnant of a post hole or support pier location. An eroded pipe was also exposed in the profile of this unit at a depth of approximately 12 inbd. Its function or association with the encountered feature is unknown.

As previously stated, the majority of artifacts collected during excavations at the Levi Jordan Plantation were recovered from this zone. The bulk of the ceramic artifacts collected from this zone consisted of white earthenware 


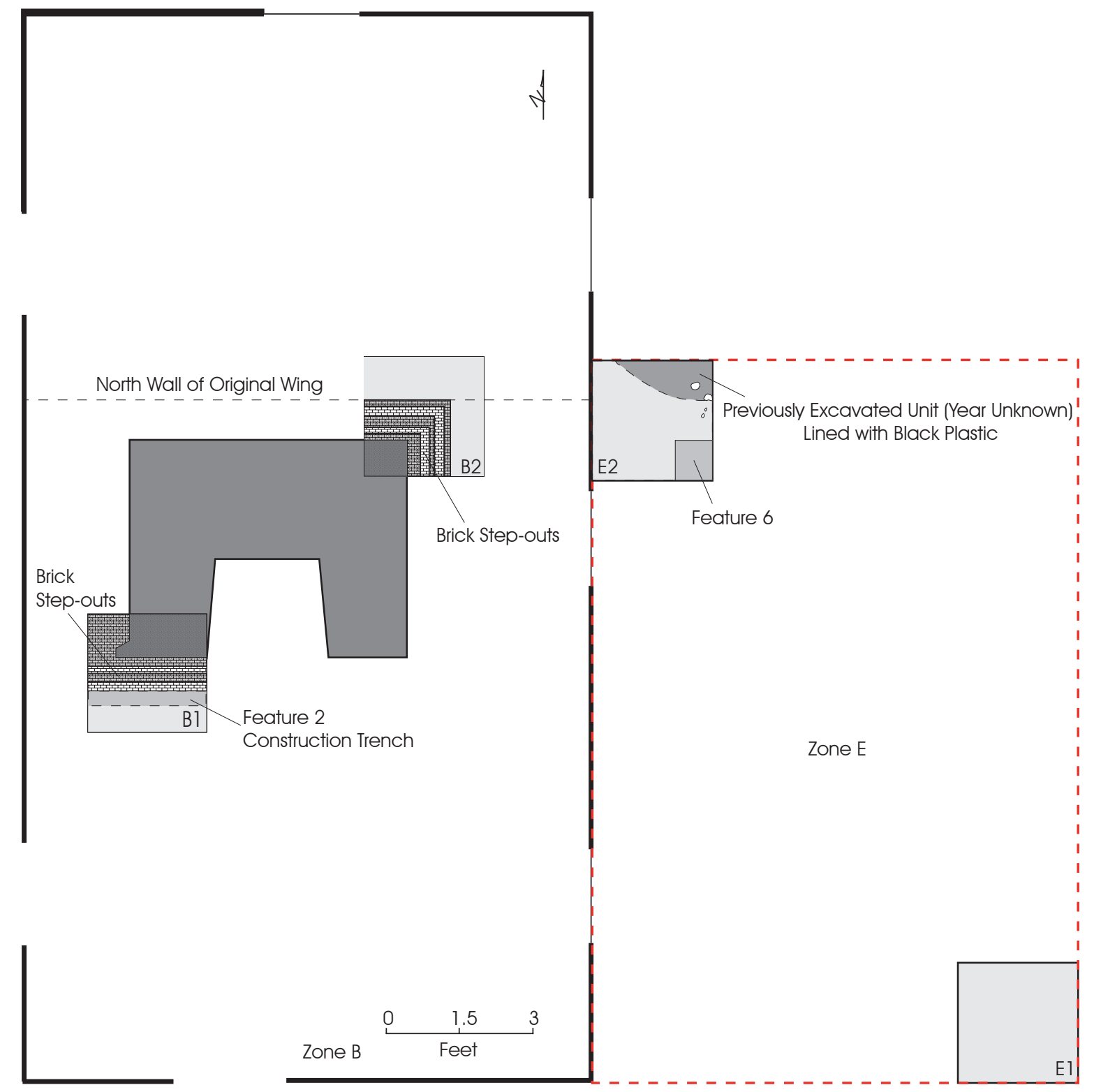

Figure 7-7. Illustration of Zones B and E indicating the locations of Units B1, B2, E1, E2, and Features 2 and 6.

and ironstone with manufacturing dates between 1850 and 1895. A piece of an English white earthenware vessel was recovered with a maker's mark from Alfred Meakin in Tunstall, England, that was used between 1875 and 1897. Additional white earthenwares collected included examples of 1900s blue decal, mid1800s spongeware, and 1800s flow blue. A semiporcelain pitcher base with a maker's mark used by the Clementson Brothers at Hanley, England, between 1870 and 1916 was recovered from Unit E1. A fragment of Lacy Glass (with the exact same pattern as the one recovered from Unit C1), probably manufactured between 1820 and 1840, was also collected from Unit E1. Other glass artifacts from Zone E included a fragment of a Ball Mason jar manufactured between 1880 and 1910. Three shotgun shell bases were also uncovered that were manufactured by the Union Metallic Cartridge Company between 1867 and 
1902. Artifacts recovered from this possible refuse midden area are supportive of domestic, household activities of an upper middle class family that occurred between the mid-1800s and early 1900s.

\section{Zone G}

Approximately $10 \mathrm{ft}$ north of the current rear wing is an area considered by TPWD to be the location of the original detached kitchen. This area was designated Zone $\mathrm{G}$ and consisted of a single excavation unit, Unit G1. Unit G1 was placed in this location in order to test this proposition.

Excavation of this unit uncovered two features that were clearly supportive of a detached kitchen structure in this area. Feature 7 was encountered during excavation of the second level (4-8 inbd) of this unit. It was a handmade brick wall foundation that was 13.5 inches wide and consisted of two parallel courses of brick facing opposite directions (see Figures 5-17, 5-18, and 5-19). Feature 8 was also encountered at this level and consisted of crushed and broken handmade brick fragments. The fact that Feature 8 resembled the interior of the fireplace hearth located in the original rear wing suggested that it was also a hearth feature. This was further supported by the presence of glazed brick fragments. As previously discussed, glazed brick fragments encountered during excavations are probably the result of excessive heat from a fireplace hearth.

Few artifacts were collected from this zone, with the majority of artifacts consisting of brick and glazed brick fragments. The largest quantity of glazed brick fragments collected during excavations at the main house was from Unit G1. A single white earthenware sherd with a manufacturing date between 1850 and 1895 was collected. While the white earthenware sherd suggests domestic activities between 1850 and 1895, the presence of square nails suggests an early to mid-1800s construction. Two-thirds of the identifiable nails collected from this unit were square nails, suggesting that this structure was constructed sometime prior to 1890 .

\section{Zone Z}

A proposed visitor center and associated maintenance area is located northeast of the main house. This area was designated as Zone $\mathrm{Z}$ and consisted of 36 shovel test units and one excavation unit. A thorough pedestrian survey was conducted in this zone, but no archaeologically significant features were encountered. However, two positive shovel tests in this location warranted the excavation of an excavation unit.

Shovel test units M and MD were excavated to a depth of 24 inches below surface. Handmade brick and glazed brick fragments were collected from STM, while only a single glazed brick fragment was collected from STMD. It was then determined that a 3x3-ft excavation unit should be placed in a location midway between these positive shovel tests.

Unit Z1 was excavated to a depth of 12 inbd, at which point sterile soil was encountered. No features or soil color changes were encountered during excavation of this unit; however, artifacts were collected and include handmade brick fragments, glazed brick fragments, brick mortar fragments, bottle glass, chimney glass, and window glass. The artifacts counts are too low to suggest this was a refuse dump. The brick and mortar artifacts do suggest that a structure may have been located in this area. Possible domestic functions can also be inferred by the presence of bottle and chimney glass. This area warrants further investigation to determine the nature of these deposits and if a structure (and its associated function) can be identified. 


\section{Conclusions}

The examination of artifacts and features uncovered during excavations provided insight into the history of the main plantation house and its occupants. An analysis of window glass provided answers to TPWD's questions concerning the construction sequences of the plantation house, as well as provided insight into locations of sections of the original structure that are no longer visible. The dating of window glass using Moir's formula helped establish construction sequences of the original structure along with additions to and modifications of the structures. The examination of amounts of window glass recovered from excavation units provided evidence of the location of structures or sections of structures that are no longer standing. Additionally, the comparison of window glass dates with hurricane dates indicated environmental factors affecting the plantation house occupants and subsequent remodeling and construction of the main house.

As previously stated, artifacts recovered from excavations at the Levi Jordan Plantation are supportive of domestic, household activities of an upper middle class family between the mid-1800s and early 1900s. Evidence of the wealth of the Jordan Plantation is not easily discerned from one's first viewing of the main house. In fact Platter (1961) describes the main house as unusual for the county: "It was functional and simple to the point of severity" (Platter 1961:159). It was not at all like neighboring ostentatious houses at the VarnerHogg and the Abner Jackson Plantations (see Figure 3-3). Yet a review of historical records for Brazoria County in 1860 ranks Levi Jordan as the sixth largest slaveholder, eighth in real estate value, and fourth in personal property value (Campbell 1989:274). This is an impressive ranking considering there were 63 active plantations in Brazoria County by 1860 (Edgington 2004:46). Additionally, Jordan seems have profited greatly from money lending, making his first loan of $\$ 10,800$ the same year he purchased the league portion that was to become the Levi Jordan Plantation (Brazoria County Deed Record H:526-528 1848). In addition to historical documentation of Levi Jordan's wealth, the socioeconomic status of the occupants of the main plantation house are easily discernible from the type of artifacts collected during excavations.

Ceramic assemblages have long been relied upon as indicators of social standing and economic wealth. Miller (1980:3) contends that social status of any object is directly related to the cost of the object. During the nineteenth century, the price of ceramic vessels was directly related to how they were decorated (Miller 1980:3). Undecorated creamwares were the cheapest ceramic vessels available at the time (Miller: 1980:3). Therefore a comparison of the amount of creamwares versus other decorated and non-decorated wares would provide an indicator of socioeconomic standing for the owner (Miller 1980). An examination of the Levi Jordan ceramic assemblage shows that creamwares compose only two percent of the assemblage (Table 7-1). Seventy-four percent of the assemblage is composed of more expensive decorated or undecorated white earthenwares, pearlwares, or porcelain ceramic fragments. This suggests that the occupants of the main house of the Levi Jordan Plantation were of a socioeconomic standing that allowed them to own expensive ceramic vessels.

An examination of the maker's marks of the recovered ceramic assemblage indicates that all but one piece were manufactured in England. As stated previously, by the mid-nineteenth century, refined earthenware ceramics were 
Table 7-1. Counts and percentages of ceramics recovered from the Levi Jordan Plantation.

\begin{tabular}{|l|c|c|c|c|}
\hline Ware Types & \multicolumn{2}{|c|}{ Counts } & \multicolumn{2}{c|}{ Percentages } \\
\hline Creamwares & 7 & & $2.0 \%$ & \\
\hline $\begin{array}{l}\text { White } \\
\text { Earthenwares }\end{array}$ & 195 & & $57.0 \%$ & \\
\hline $\begin{array}{l}\text { (Decorated } \\
\text { WE) }\end{array}$ & & 24 & & $7.0 \%$ \\
\hline $\begin{array}{l}\text { (Undecorated } \\
\text { WE) }\end{array}$ & & 171 & & $50.0 \%$ \\
\hline Ironstone & 82 & & $24.0 \%$ & \\
\hline Pearlware & 2 & & $0.6 \%$ & \\
\hline Porcelains & 54 & & $15.8 \%$ & \\
\hline $\begin{array}{l}\text { Smooth } \\
\text { Brownware }\end{array}$ & 1 & & $0.3 \%$ & \\
\hline Yellowware & 1 & & $0.3 \%$ & \\
\hline Total & $\mathbf{3 4 2}$ & & $\mathbf{1 0 0 . 0 \%}$ & $\mathbf{5 7 . 0 \%}$ \\
\hline
\end{tabular}

manufactured in the United States (Barber 2001 [1904]). Those who wished to own English manufactured ceramic vessels would have had to pay extra for shipping, tariffs, and taxes. Only those who possessed a higher socioeconomic standing could afford to purchase imported English pottery (Miller 1980).

When comparing undecorated, everyday ceramic sherd amounts to decorated or highend (pearlware, ironstone, porcelain, and semiporcelain) ceramic sherd amounts we see that undecorated sherds outnumber the decorated sherds by 3 to 1 . However, everyday wares are 20 times more likely to be broken and discarded (ending up in archaeological contexts) than decorated wares, as the latter are more treasured and expensive and used only for special occasions (Miller 1980:13-15). Additionally, cups are more susceptible to breakage due to the amount of handling they experience (Miller 1980:13). Of the four cup fragments (cup handles) recovered from excavations, three were porcelain, indicating that porcelain wares were utilized on a frequent basis. Even though undecorated wares appear to outnumber the amounts of decorated wares, it is important to remember that these decorated wares often cost twice as much as the undecorated wares. The price of a transferware soup tureen in 1855 was 684 English Pence per dozen, while a shelldecorated edgeware tureen cost 360 English Pence per dozen, and an undecorated creamware version cost only 324 English Pence per dozen (Miller 1980:23-25).

It can be clearly discerned from an examination of the Levi Jordan Plantation's ceramic assemblage that the occupants of the main house possessed an elevated socioeconomic standing. In 1850, 2.2 percent of the population of Texas owned real estate valued between $\$ 10,000$ and $\$ 19,999$ (Lowe and Campbell 1977:38). Jordan's real estate at this time was valued at $\$ 11,105$, placing him within this bracket. However, by 1860 his real estate is valued at $\$ 69,000$, placing him in the top 0.7 percent of Texas landholders (Lowe and Campbell 1977:38).

\section{Recommendations}

In summary, the goals established by TPWD relating to the layout and construction of the main house have been addressed. However, excavations in the areas of interest designated by TPWD have exposed additional questions. The extent of the terrace area in Zone A, encountered during excavations of Units A4 and A5, needs to be further addressed. Furthermore, horizontal excavation of the brick pathways is recommended to provide data on their extent and possible linkage to the detached kitchen structure uncovered in Zone $\mathrm{G}$ and/or other possible outbuildings.

Data gathered from excavation units in Zones B and C provided necessary information on the construction of both chimney foundations 
as well as the location on the north wall of the original rear wing. No further excavations in these areas are recommended.

Further excavations in Zone E could lend additional information on the extent of its refuse deposit and the nature of the feature located in Unit E1. Additionally, units excavated in this location were unable to fully answer questions concerning the construction and location of the original rear wing or the location of an eastern porch. The excavation of additional test units in this location would provide more data to address these questions.

The uncovering of a handmade brick walkway in Unit D2 clearly warrants further investigation in Zone D. Additional excavations units placed in this area would provide information on the nature and function of the walkway encountered. The placement of excavation units on the eastern side of the front porch area will also provide further data concerning the location of the original porch.

The single excavation unit placed in Zone G did not fully address the questions raised about the detached kitchen structure. In order to gain valuable information regarding the size and orientation of this structure, additional excavation in this area is needed.

The heavy vegetation and foliage present in Zone Z, the visitor area, greatly hampered visual survey and placement of shovel test and excavation units. It would be necessary to clear the area in order to better evaluate through visual survey. While two shovel test units and one excavation unit did produce historic artifacts, the information gathered was inconclusive and requires additional investigation. CAS strongly recommends that the area be subjected to further archaeological investigations before construction in this area commences. 


\section{References Cited}

Americans for Common Cents

2005 A Brief History of the US Coin. Americans for Common Cents: The Penny Information Homepage. Electronic document, http://www.pennies.org/history.html, accessed August 2005.

Aten, Lawrence E.

1983 Indians of the Upper Texas Coast. Academic Press, New York.

Barber, Edwin

2001 [1904] $\quad$ Marks of American Potters. Blackburn Press, New Jersey.

Barber, John

2003 SAIR3: Bronze Age farms and Iron Age farm mounds of the Outer Hebrides. Scottish Archaeological Internet Reports, published by the Society of Antiquaries of Scotland. Electronic document, http://www.sair.org.uk/sair3/sair3-chap09.pdf, accessed July 2005.

Barnes, Mary K.

1999 Church and Community: An Archaeological Investigation at the Levi Jordan Plantation, Brazoria County, Texas. Unpublished Masters thesis, Department of Anthropology, The University of Houston.

Barrera, Rebecca A.

1999 The Jordan Plantation: Black and White Interpretations of the "Backyard” an Archaeological Study of the Backyard Area of the Levi Jordan Plantation. Unpublished Senior Honors thesis, Department of Anthropology, The University of Houston.

Birks, Steve

2005 Stoke-on-Trent, Pottery and Ceramics. Electronic document, http://www.thepotteries.org, accessed August 2005.

Breen, Walter

1988 Walter Breen’s Complete Encyclopedia of U.S. and Colonial Coins. F.C.I. Press/Doubleday, New York.

Bressett, Kenneth (editor)

2005 The Official American Numismati Association Grading Standards for United States Coins. $6^{\text {th }}$ ed. Whittman Publishing, LLC, Atlanta. 
Brown, Kenneth L.

1994 Material Culture and Community Structure: The Slave and Tenant Community At Levi Jordan's Plantation, 1848-1892. In Working Toward Freedom: Slave Society and Domestic Economy in the American South, edited by Larry E. Hudson, Jr., pp. 95-118. University of Rochester Press, New York.

2004 Ethnographic Analogy, Archaeology, and the African Diaspora: Perspectives from a Tenant Community. Historical Archaeology, 34(1):79-89.

2005 The Levi Jordan Plantation Historical Archaeological Research Design. The Levi Jordan Plantation State Historical Site, Brazoria County, Texas Technical Report Series, Vol. 1. Texas Parks and Wildlife Department, Austin.

Brown, Kenneth L., and Doreen C. Cooper

1990 Structural Continuity in an African-American Slave and Tenant Community. Historical Archaeology 24(4):95-118.

Bruner, David E.

1996 Hidden Power: Burial Practices from an African American Slave and Tenant Community. Unpublished Masters thesis, Department of Anthropology, The University of Houston.

Bureau of Land Management

2005 Machine Made Dating. BLM Historic Glass Bottle Identification \& Information Website. Electronic document, http://www.blm.gov/historic_bottles/machinemadedating.htm, accessed September 2005.

Busch, Jane

1991 Second Time Around: A Look at Bottle Reuse. In Approaches to Material Culture: Research for Historical Archaeologist, pp. 113-126. Society for Historical Archaeology, California \& Pennsylvania.

California Department of Parks \& Recreation

2004 Maker's Mark Type Collection Photo Gallery. California State Parks. Electronic document, http://www.parks.ca.gov/?page_id=22319, accessed August 2005.

Campbell, Randolph B.

1989 An Empire for Slavery: The Peculiar Institution in Texas, 1821-1865. Louisiana State University Press, Baton Rouge.

Campbell, Randolph B., and Richard G. Lowe

1977 Wealth and Power in Antebellum Texas. Texas A\&M University Press, College Station. 
Carnes-McNaughton, Linda

1998 European Trade Artifacts. In Excavating Occaneechi Town: Archaeology of an EighteenthCentury Indian Village in North Carolina, CD-ROM. Edited by R. P. Stephen Davis Jr., Patrick Livingood, Trawick Ward, and Vincas P. Steponaitis. University of North Carolina Press, Chapel Hill.

City of Stoke-on-Trent

2004 The Potteries Museum \& Art Gallery. Stoke-on-Trent Museums. Electronic document, http:// www2002.stoke.gov.uk/museums/pmag/ceramics/infosheets, accessed August 2005.

Cole, Dick

2005 Anchor Hocking Base Plate. Midwest Antique Fruit Jar \& Bottle Club. Electronic document, http://www.fruitjar.org?plantCodes?Anchor\%20Hocking_files/image003.jpg, accessed September 15, 2005.

Columbia Democrat [Brazoria County, Texas]

1853 Article. 29 November. Brazoria County, Texas.

Cooper, Doreen C.

1989 The Archaeology of Abandonment at the Levi Jordan Plantation. Unpublished Masters thesis, Department of Anthropology, The University of Houston.

Crenwelge, Gerald W., J. D. Crout, Edward L. Griffin, M. L. Golden, and J. K. Baker

1981 Soil Survey of Brazoria County, Texas. United States Department of Agriculture, Soil Conservation Service, Washington D.C.

Curlee, Abigail

1932 A Study of Texas Slave Plantations, 1822 to 1865. Unpublished Ph.D. dissertation, Department of History, The University of Texas at Austin.

Day, Grant L.

2001 Window Glass Dating: When was the McConnell's Homestead Built? Paper presented at the 4th Annual South Central Historical Archaeology Conference, Little Rock, Arkansas.

de Resendes, Eduardo

2005 Buffalo Nickels. About.com. Electronic document, http://coins.about.com/library/weekly/ aa033101a.htm, accessed August 2005.

Earls, Amy C., and Marybeth S. F. Tomka

1994 Historic and Prehistoric Archeological Excavations at Varner-Hogg Plantation State Historical Park, Brazoria County, Texas. Texas Parks and Wildlife Department, Public Lands Division, Cultural Resources Program, Austin. 
Edgington, Justin B.

2004 Historic Context Report, SH 35, Brazoria County, Texas. In National Register Eligibility Testing of Site 41BO184, Brazoria County, Texas, by Richard B. Mahoney and Steve A. Tomka, Appendix A, pp. 34-63. Archaeological Survey Report, No. 349. Center for Archaeological Research, The University of Texas at San Antonio. Available from Environmental Affairs Division, Texas Department of Transportation, Austin, as Archaeological Studies Program, Report No. 63.

Epstein, Diana, and Millicent Safro

1991 Buttons. Harry N. Abrams, Inc., New York.

Few, Joan

1990 Texas' Early Sugar Industry: A Comparative Study of Four Antebellum Sugar Mills in Brazoria County, Texas. Bulletin of the Texas Archeological Society 70:533-540.

1994 Sugar and Cotton Production in the Texas Sugar Bowl. In Antebellum Texas, Brazos Style, 1994 Session. Brazoria County Historical Museum, February 26, 1994, Angleton, Texas.

1999 Lake Jackson State Archeological Landmark (41BO172): Report of the 1994 and 1995 Texas Archeological Society Field Schools and Additional 1996-1998 Excavations. Bulletin of the Texas Archeological Society 70:489-510.

Fields, Ross C.

1995 The Archeology of the Post Oak Savannah of East Central Texas. Bulletin of the Texas Archeological Society, 66:301-330.

Freeman, Martha Doty

2003 An Overview of the Development of an Historic Landscape on the San Bernard River, Brazoria County, Texas, and a History of the Levi Jordan Plantation. TBG Partners, Inc., Austin.

Fox, Anne

1995 Ceramics from Colonial Sites in Texas, unpublished manuscript in possession of the author.

Garcia-Herreros, Jorge

1998 A Munitions Maker’s Cabin: An Archaeological Investigation at the Levi Jordan Plantation, Brazoria County, Texas. Unpublished Masters thesis, Department of Anthropology, The University of Houston.

Godden, Geoffrey A.

1980 Godden's Guide to Mason's China and the Ironstone Wares. The Antique Collectors' Club Ltd., Woodbridge, England.

Greer, Georgeanna H.

1981 American Stonewares, The Art and Craft of Utilitarian Potters. Schiffer, Exton. 
Greer, Georgeanna H., and Harding Black

1971 The Meyer Family: Master Potters of Texas. Trinity University Press, San Antonio.

Gurcke, Karl

1987 Bricks and Brickmaking; A Handbook for Historical Archaeology. The University of Idaho Press, Moscow, Idaho.

Harris, René

2005 David Graham Mills. The Handbook of Texas Online. Electronic document, http://www.tsha. utexas.edu/handbook/online/articles/print/MM/fmi64.html, accessed 26 April 2005.

Harris, Robert N.

1999 Craft Specialization in a 19th Century African-American Community: The Shell Carver's Cabin on the Levi Jordan Plantation, Brazoria County, Texas. Unpublished Masters thesis, Department of Anthropology, The University of Houston.

Hillard, Sam B.

1990 Plantations and the Molding of the Southern Landscape. In The Making of the American Landscape, edited by Michael P. Conzen, pp. 104-126. Unwin Hynman Inc., Boston.

Husfloen, Kyle

1994 Antique Trader American Pressed Class and Bottles, Antique Trader Publications, Dubuque. 2000 Antique Trader Pottery and Porcelain Ceramics, Price Guide. $3^{\text {rd }}$ ed. Krause Publications, Iola.

Israel, Fred L. (editor)

18971897 Sears, Roebuck Catalog. Chelsea House, New York.

Jones, Olive, and Catherine Sullivan

1989 The Parks Canada Glass Glossary for the Description of Containers, Tableware, Flat Glass, and Closures. National Historic Parks and Sites Branch, Canadian Parks Service, Ottawa.

Jurney, David H.

1988 Cut and Wire Nails: Functional and Temporal Interpretations. In Historic Farming on the Hogwallow Prairies: Ethnoarchaelogical Investigations of the Mountain Creek Area, North Central Texas, compiled by David H. Jurney, Susan A. Lebo, and Melissa M. Green, pp. 315-324. Joe Pool Lake Archaeological Project, Vol. 2. Archaeology Research Program, Institute for the Study of Earth and Man, Southern Methodist University, Dallas.

Ketchum, William C., Jr.

2000 American Pottery \& Porcelain. Black Dog and Leventhal Publishers, New York. 
Kleiner, Diana J.

2005 Brazoria County. The Handbook of Texas Online. Electronic document, http://www.tsha. utexas.edu/handbook/online/articles/print/BB/hcb12.html, accessed 21 April 2005.

Kovel, Ralph, and Terry Kovel

2002 Silver cups marked momentous occasions. The Milwaukee Journal Sentinel 6 October. Milwaukee, Wisconsin.

Lowe, Richard G., and Randolph B. Campbell

1987 Planters and Plain Folk, Agriculture in Antebellum Texas. Southern Methodist University, Dallas.

McAllister, Judith

2005 Judy’s Lovelies. Ruby Lane. Electronic document, http://www.rubylane.com/ni/shops/ tomjudy/iteml/4605\#pic2, accessed August 2005.

McCormick

2005 Company History. McCormick Home Page. Electronic Document, http://www.mccormick. com/content.cfm?ID=11244, accessed August 2005.

McDavid, Carol

1996 The Levi Jordan Plantation: From Archaeological Interpretation to Public Interpretation. Unpublished Masters Thesis, Department of Anthropology, The University of Houston.

1997 Descendants, Decisions, and Power: The Public Interpretation of the Archaeology of the Levi Jordan Plantation. Historical Archaeology, 31(3):114-131.

1998 The Levi Jordan Plantation Website. Electronic document, http://www.webarchaeology.com, accessed June 2005.

Mackay, James

2002 Antiques at a Glance: Ceramics. PRC Publishing Ltd., London.

Mattiza, Dorothy B.

1993100 Texas Wildflowers. Southwest Parks and Monuments Association, Tucson, Arizona.

Mahoney, Richard B., and Steve A. Tomka

2004 National Register Eligibility Testing of Site 41BO184, Brazoria County, Texas.

Archaeological Survey Report, No. 349. Center for Archaeological Research, The University of Texas at San Antonio. Available from Environmental Affairs Division, Texas Department of Transportation, Austin, as Archaeological Studies Program, Report No. 63. 
Majewski, Teresita, and Michael J. O’Brien

1987 The Use and Misuse of Nineteenth-Century English and American Ceramics in Archaeological Analysis. In Advances in Archaeological Method and Theory, Vol. II, edited by Michael B. Schiffer, pp. 97-209. Academic Press, New York.

May, Cynthia

2005 English Transferware China. About.com. Electronic document, http://www.about-antiquies. com?English-Transferware-China.htm, accessed September 15, 2005.

Miller, George L.

1980 Classification and Economic Scaling of the 19th Century Ceramics. Historical Archaeology, 14:1-40.

1991 A Revised Set of CC Index Values for Classification and Economic Scaling of English Ceramics from 1787 to 1880. Historical Archaeology 25:1-23.

Mercado-Allinger, Patricia A., Ross C. Fields, Kathleen Gilmore, and Nancy Reese

1984 Inventory and Assessment of Cultural Resources, Clear Creek Channel Improvement Project, Galveston County, Texas. Reports of Investigations Number 26, Prewitt and Associates, Inc., Austin.

Moir, Randall W.

1987a Socioeconomic and Chronometric Patterning of Window Glass. In Historic Buildings, Material Culture, and People of the Prairie Margin, edited by David H. Jurney and Randall W. Moir, pp. 73-82. Richland Creek Technical Series, Vol. V. Archaeology Research Program, Institute for the Study of Earth and Man, Southern Methodist University, Dallas.

1987b Refined Earthenwares and Ritual Ceramics Traditions. In Historic Buildings, Material Culture, and People of the Prairie Margin, edited by David H. Jurney and Randall W. Moir, pp. 97-120. Richland Creek Technical Series, Vol. V. Archaeology Research Program, Institute for the Study of Earth and Man, Southern Methodist University, Dallas.

1988 Windows and Window Glass. In Historic Farming on the Hogwallow Prairies; Ethnoarchaeological Investigations of the Mountain Creek Area, North Central Texas, compiled by David H. Jurney, Susan A. Lebo, and Melissa M. Green, pp. 263-272. Joe Pool Lake Archaeological Project, Vol. II. Archaeology Research Program, Institute for the Study of Earth and Man, Southern Methodist University, Dallas.

Munsey, Cecil

1970 The Illustrated Guide to Collecting Bottles. Hawthorn Books, Inc. Publishers, New York.

Nelson, Lee H.

1968 Nail Chronology as an Aid to Dating Old Buildings. Technical Leaflet 48. American Association for State and Local History, Nashville. 
Nickels, David L.

2003 Appendix C. Ceramics. In Archaeological Testing of the Burleson Homestead at 41HY37 Hays County, Texas, assembled by C. Britt Bousman and David L. Nickels, pp. 123-130. Archaeological Studies Report No. 4. Center for Archaeological Studies, Texas State University-San Marcos.

Noël Hume, Ivor

1969 A Guide to Artifacts of Colonial America. University of Pennsylvania Press, Philadelphia.

Pattern Glass

2005 Flint Glass. PatternGlass.com. Electronic document, http://www.patternglass.com/KindFlint/ flint.htm, accessed September 2005.

Patterson, Leland W.

1995 The Archeology of Southeast Texas. Bulletin of the Texas Archeological Society 66:239-264.

Platter, Alan A.

1961 Educational, Social, and Economic Characteristics of the Plantation Cultures of Brazoria County, Texas. Unpublished PhD dissertation, College of Education, The University of Houston.

Poole, Juliann

1982 Appendix V: Fanthrop Inn: A Study of Nineteenth and Twentieth Century Buttons. In Archaeological Excavations at Fanthrop Inn State Historic Site (41GM79), Grimes County, Texas, by J. David Ing and John Hart, pp. 278-235. Texas Parks and Wildlife Department, Austin.

Powers, Betsy J.

1994 From Cotton Fields to Oil Fields: Economic Development in a New South Community, 18601920. Unpublished Ph.D. dissertation, College of Education, The University of Houston.

Raska, Ginny, editor

1998 Sallie McNeill’s Diary. Manuscript in possession of the editor, Brazoria County, Texas.

Rehder John B.

1999 Delta Sugar: Louisiana’s Vanishing Plantation Landscape. The Johns Hopkins University Press, Baltimore.

Remington Arms Company

2005 Remington Arms Company, History of the Firearms Business, 1816-Present. Remington Company History. Electronic document, http://www.remington.com/aboutus/corphistory. htm, accessed August 2005. 
Ricklis, Robert A.

1995 Prehistoric Occupation of the Central and Lower Texas Coast: A Regional Overview. Bulletin of the Texas Archeological Society 66:265-300.

Robacker, Earl F., and Ada F. Robacker

1978 Spatterware and Sponge: Hardy Perennials of Ceramics. A.S. Barnes and Company, South Brunswick, New Jersey.

Roenke, Karl G.

1978 Flat Glass, Its Use as a Dating Tool for Nineteenth Century Archaeological Sites in the Pacific Northwest and Elsewhere. Northwest Anthropological Research Notes, Memoir No. 4. Moscow, Idaho.

Roth, David

2005 Texas Hurricane History: Late 19th Century. National Weather Service, Southern Region Headquarters. Electronic document, http://www.srh.noaa.gov/lch/research/txlate19hur.htm, accessed July 2005.

Russell, Lori S.

1968 A Heritage of Light: Lamps and Lighting in the Early Canadian Home. University of Toronto Press, Toronto.

Sauer, Sandra R., Art Black, and Cynthia Brandimarte

1998 Sebastopol State Historical Park (41GU9), Seguin, Texas: Archaeological Excavations, 1978-1988. Reports of Investigations, Number 111. Prewitt and Associates, Inc., Austin.

Snyder, Jeffery B.

1995 A Pocket Guide to Flow Blue. Schiffer Publishing Ltd., Hong Kong.

Steinhauer, Curtis

2004 UMC Headstamps. Cartridge Corner Website. Electronic document, http://members.shaw. ca/cstein0/umc.htm, accessed August 2005.

Strobel, Abner J.

1926 The Old Plantations and their Owners of Brazoria County, Texas. The Union National Bank, Houston.

Story, De Ann, Janice A. Guy, Barbara A. Burnett, Martha Doty Freeman, Jerome C. Rose, D. Gentry Steele, Ben W. Olive, and Karl J. Reinhard

1990 The Archeology and Bioarcheology of the Gulf Coastal Plain. Arkansas Archeological Survey Research Series No. 38. Arkansas Archeological Survey, University of Arkansas, Fayetteville. 
Stothert, Karen E., Anne Fox, and K. Gross

1992 Early Nineteenth Century Settlements and Ceramics of the Tambo River, Southwest Coast of Ecuador. Paper presented at the 1992 Conference of Historical and Underwater Archaeology, Society for Historical Archaeology, Kingston, Jamaica.

Sullivan, Catherine

1984 Lamp Chimneys. In Lighting Devices in the National Reference Collection, Parks Canada, by E. I. Woodhead, C. Sullivan, and G. Gusset, pp. 58-64. Studies in Archaeology, Architecture, and History, National Historic Parks and Sites Branch, Parks Canada, Environment Canada, Ottawa.

Tennis, Cynthia L.

1997 Ceramic Patterns and Variation. In Archaeology at the Alamodome: Investigations of a San Antonio Neighborhood in Transition, Volume III Artifacts and Special Studies, edited by Anne A. Fox, Marcie Renner, and Robert J. Hard, pp. 1-37. Archaeological Survey Report No. 238. Center for Archaeological Research, The University of Texas at San Antonio.

Texas Historical Commission (THC)

2005 Texas Archeological Sites Atlas. Electronic document, http://nueces.thc.state.tx.us, accessed April 2005.

Texas Parks and Wildlife Department

1995 Archeology Lab Manual. Cultural Resources Program, Texas Parks and Wildlife Department, Austin, Texas.

2003 Levi Jordan Plantation State Historic Site, Brazoria, Texas: Discovery Phase. TBG Partners, Texas Parks and Wildlife Department, Austin, Texas.

2005a Physiographic Regions of Texas. Texas Parks \& Wildlife Department Website. Electronic document, http://www.tpwd.state.tx.us/nature/tx-eco95.htm, accessed February 2005.

2005b Oak-Prairie Wildlife Management. Texas Parks and Wildlife Department Website. Electronic document, http://www.tpwd.state.tx.us/landwater/land/habitats/oak_prairie/, accessed August 2005.

Toulouse, Julian Harrison

1971 Bottle Makers and Their Marks. Blackburn Press, Caldwell.

University of Utah, Department of Anthropology

1992 474-Cartridges. Intermountain Antiquities Computer System (IMACS) Guide. Electronic document, http://www.anthro.utah.edu/IMACs/474-Cartridges.pdf, accessed August 2005.

Vlach, John Michael.

1993 Back of the Big House - The Architecture of Plantation Slavery. University of North Carolina Press, Chapel Hill. 
Weir, Merle

2001 Bailey, James Briton. The Handbook of Texas Online. Electronic document, http://www.tsha. utexas.edu/handbook/online/articles/BB/fba8.html, accessed August 2005.

2005 Josiah Hughes Bell. The Handbook of Texas Online. Electronic document, http://www.tsha. utexas.edu/handbook/online/articles/BB/fbe38.html, accessed 21 April 2005.

White, Raymond E.

1957 Cotton Ginning in Texas to 1861. Southwestern Historical Quarterly 61.

Whittemore, Joyce

1992 The Book of Buttons. Dorling Kinsersley, New York.

Wooster, Ralph F.

1961 Notes on Texas’ Largest Slaveholders, 1860. Southwestern Historical Quarterly 65:72. 


\section{Appendix A \\ Window Glass Distribution Charts}

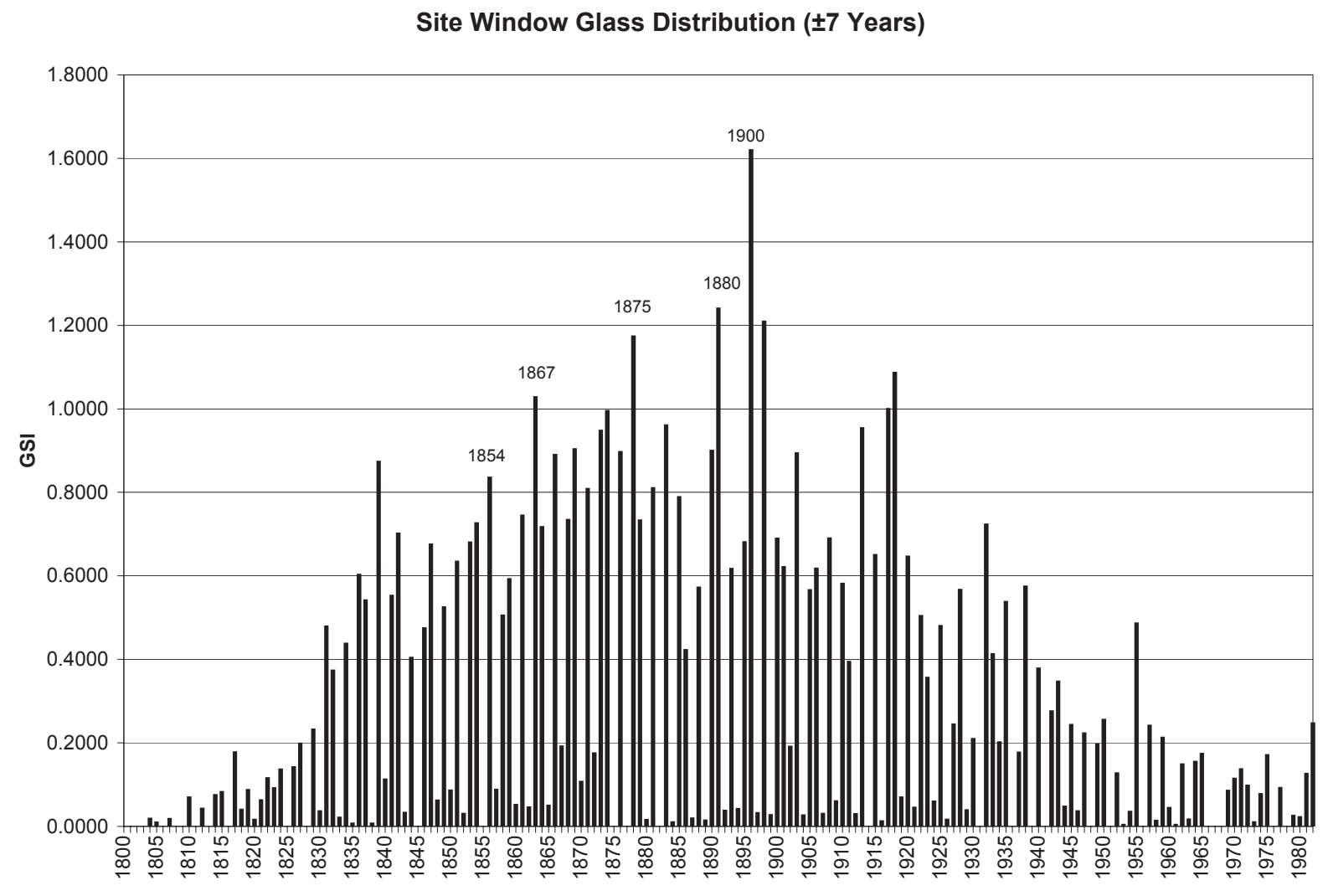

Figure A-1. Bar graph showing temporal window glass distribution at the Levi Jordan State Historic Site (41BO165) and associated hurricane event dates. 


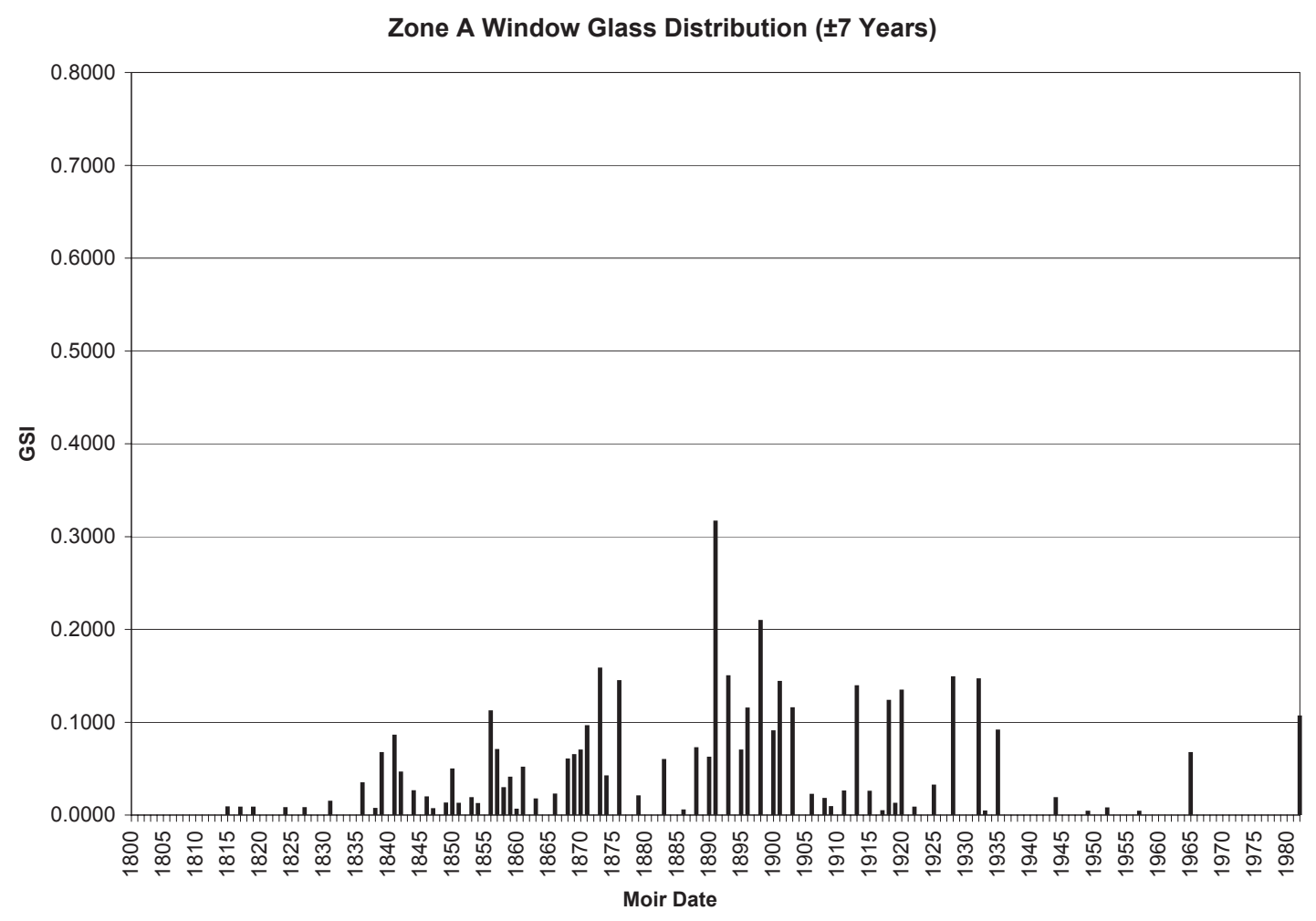

Figure A-2. Bar graph showing the temporal window glass distribution for Zone A at the Levi Jordan Plantation State Historical Site (41BO165).

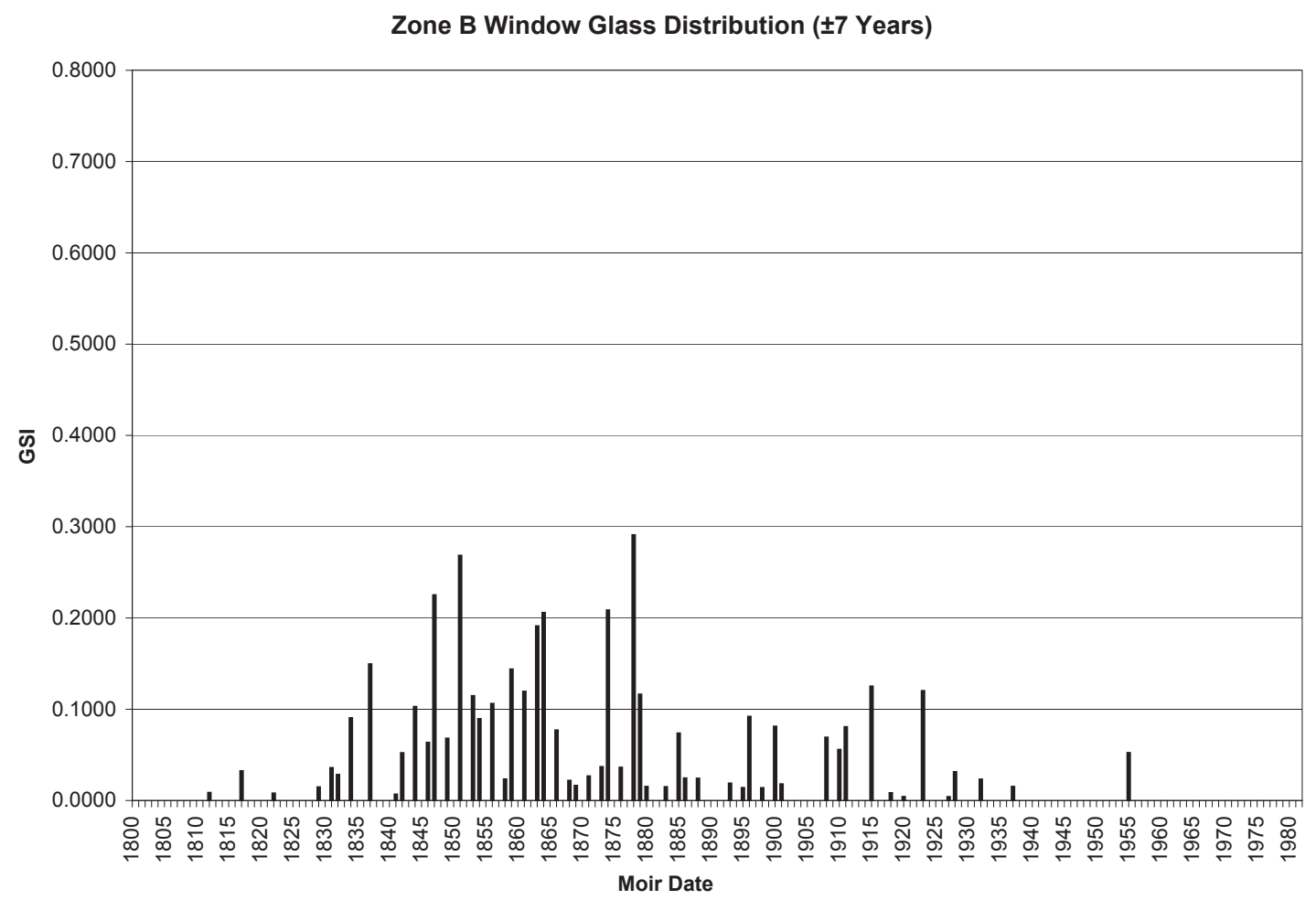

Figure A-3. Bar graph showing the temporal window glass distribution for Zone B at the Levi Jordan Plantation State Historical Site (41BO165). 


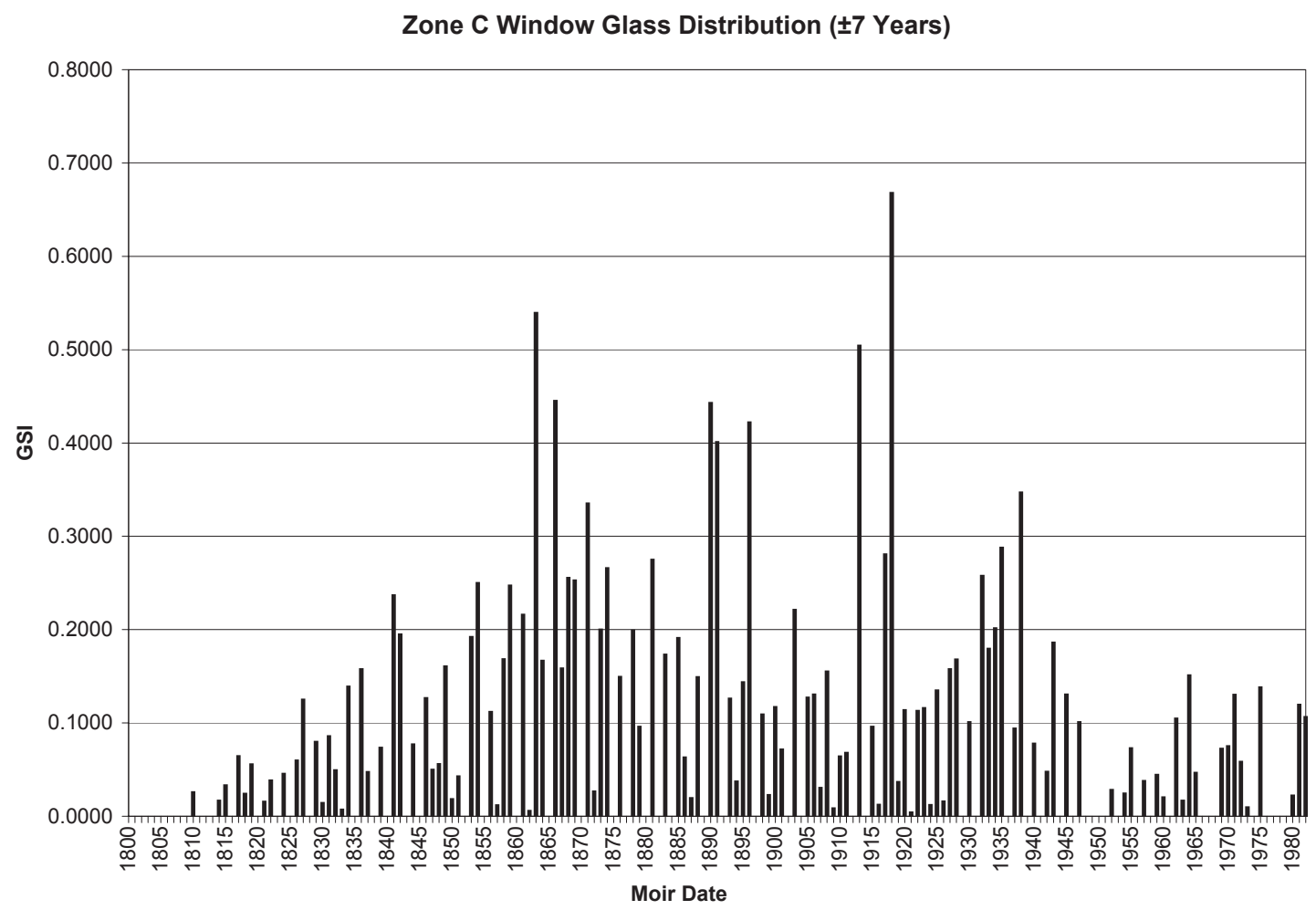

Figure A-4. Bar graph showing the temporal window glass distribution for Zone C at the Levi Jordan Plantation State Historical Site (41BO165).

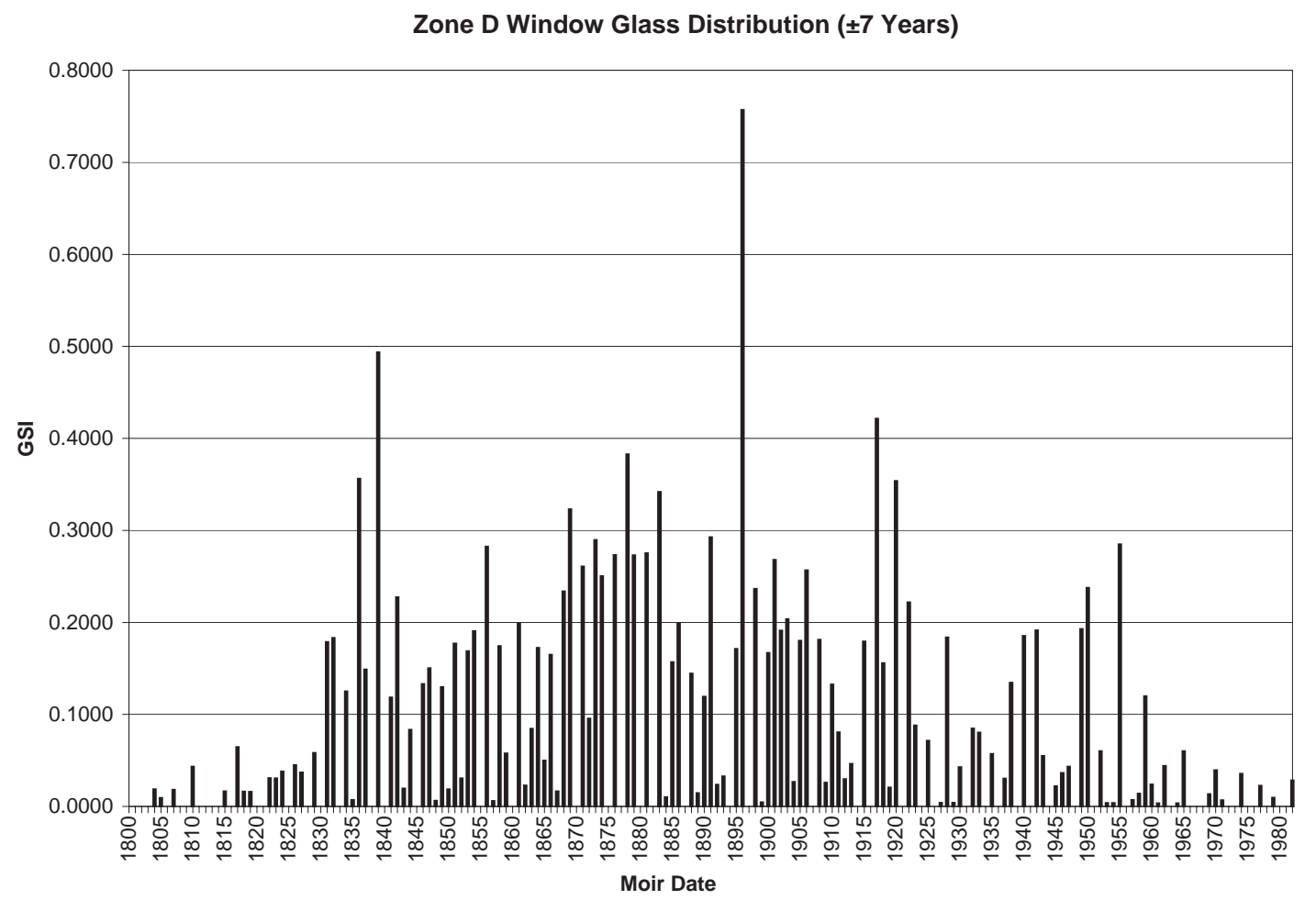

Figure A-5. Bar graph showing the temporal window glass distribution for Zone D at the Levi Jordan Plantation State Historical Site (41BO165). 


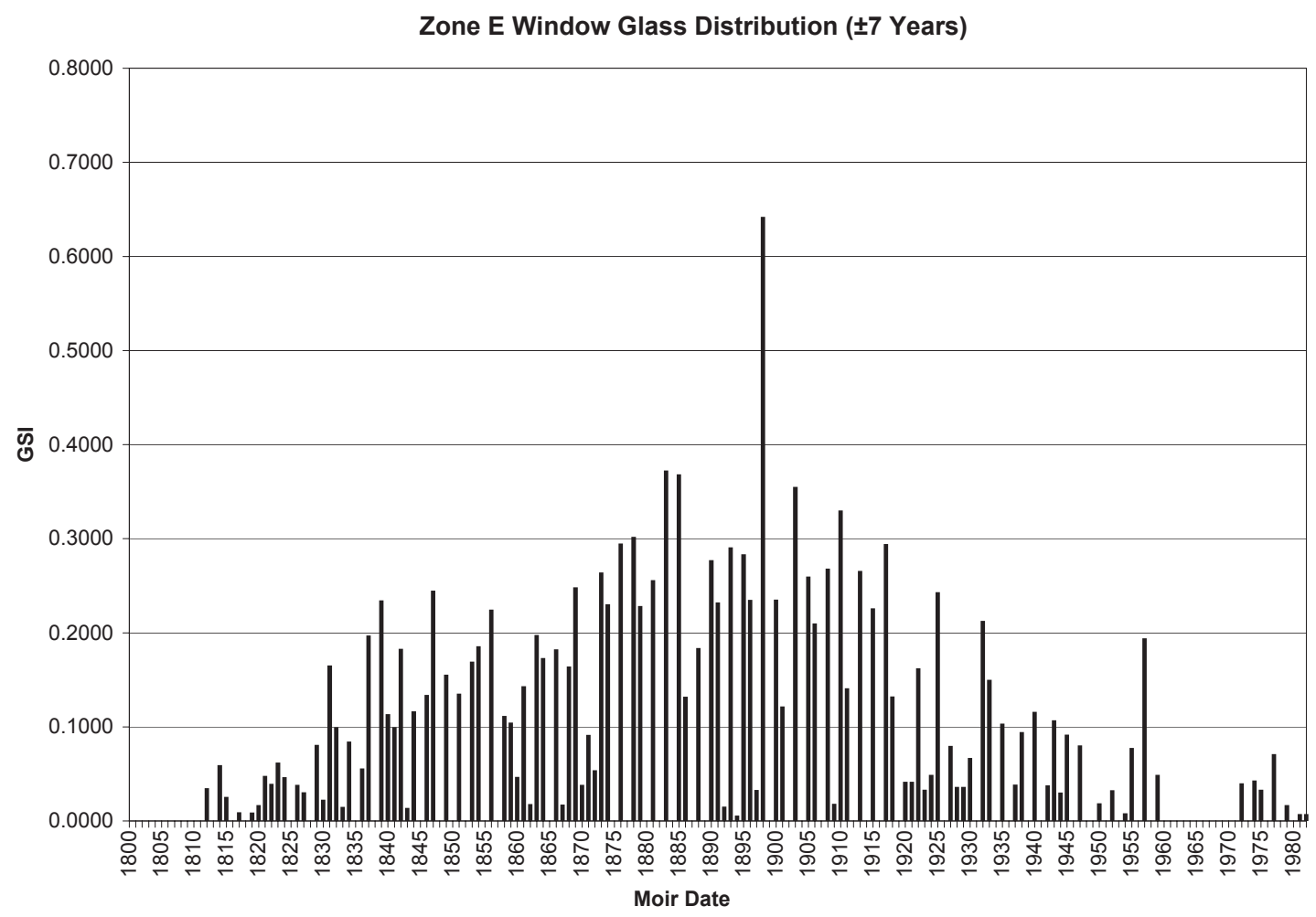

Figure A-6. Bar graph showing the temporal window glass distribution for Zone E at the Levi Jordan Plantation State Historical Site (41BO165).

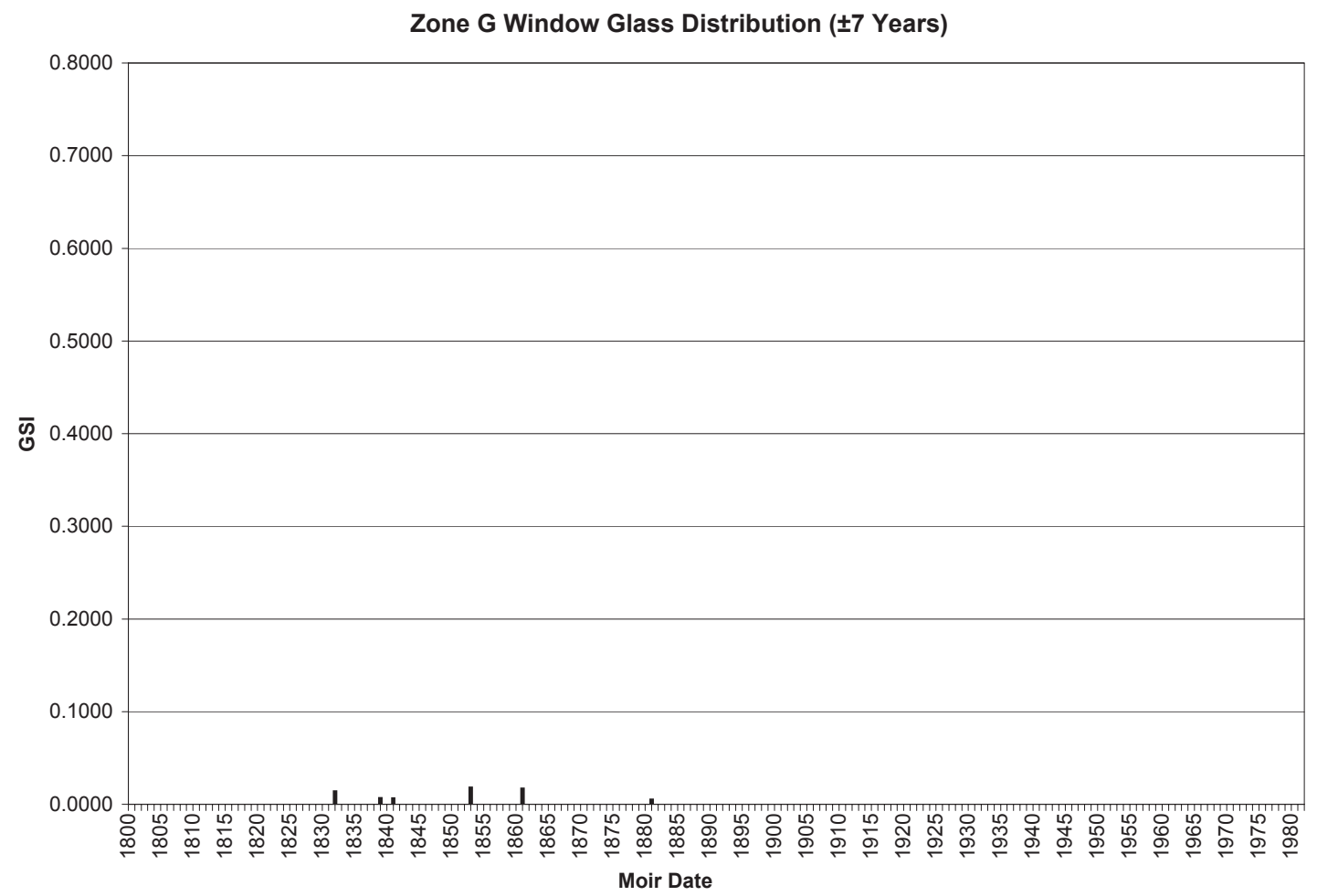

Figure A-7. Bar graph showing the temporal window glass distribution for Zone $\mathrm{G}$ at the Levi Jordan Plantation State Historical Site (41BO165). 


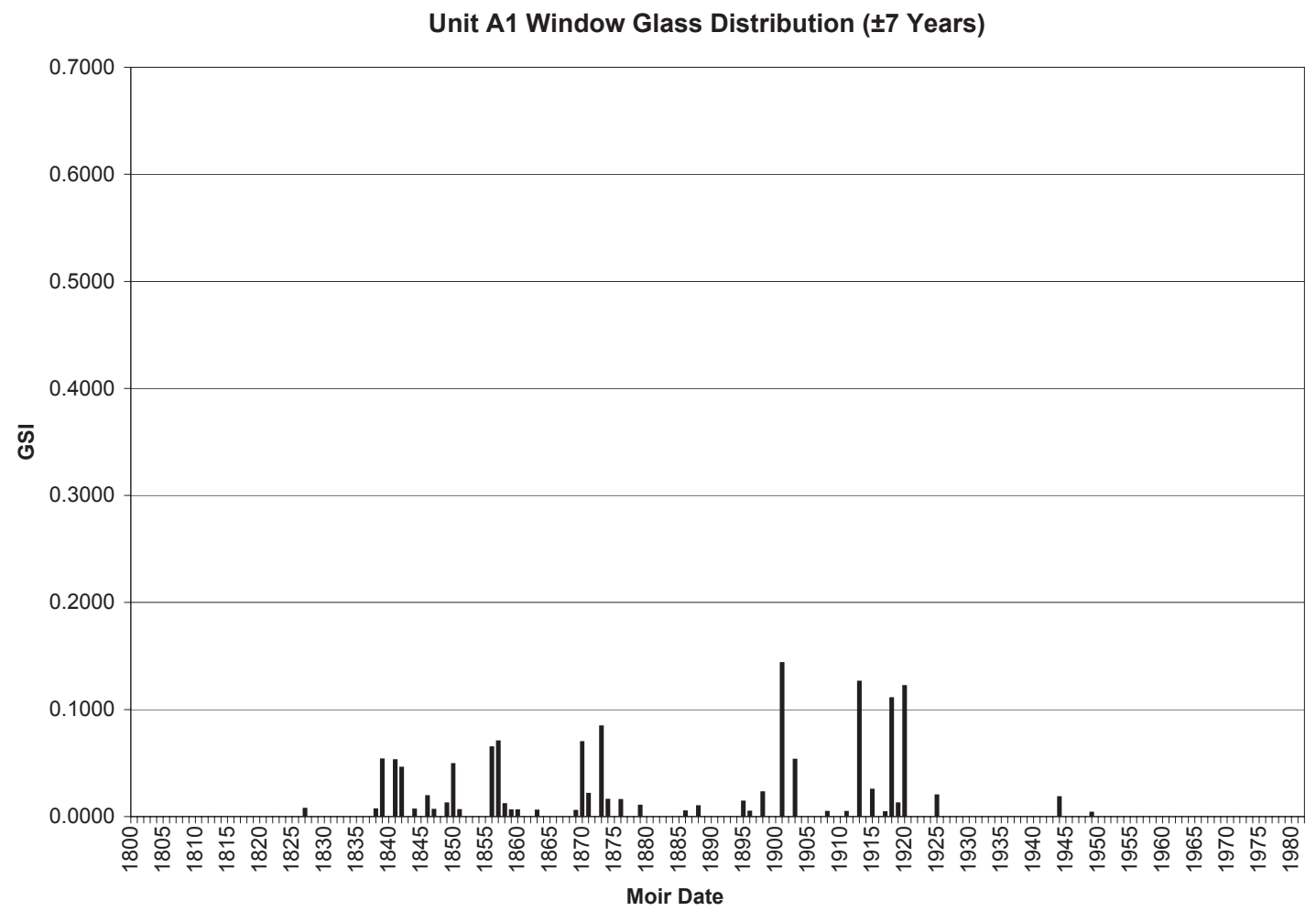

Figure A-8. Bar graph showing the temporal window glass distribution for Unit A1 at the Levi Jordan Plantation State Historical Site (41BO165).

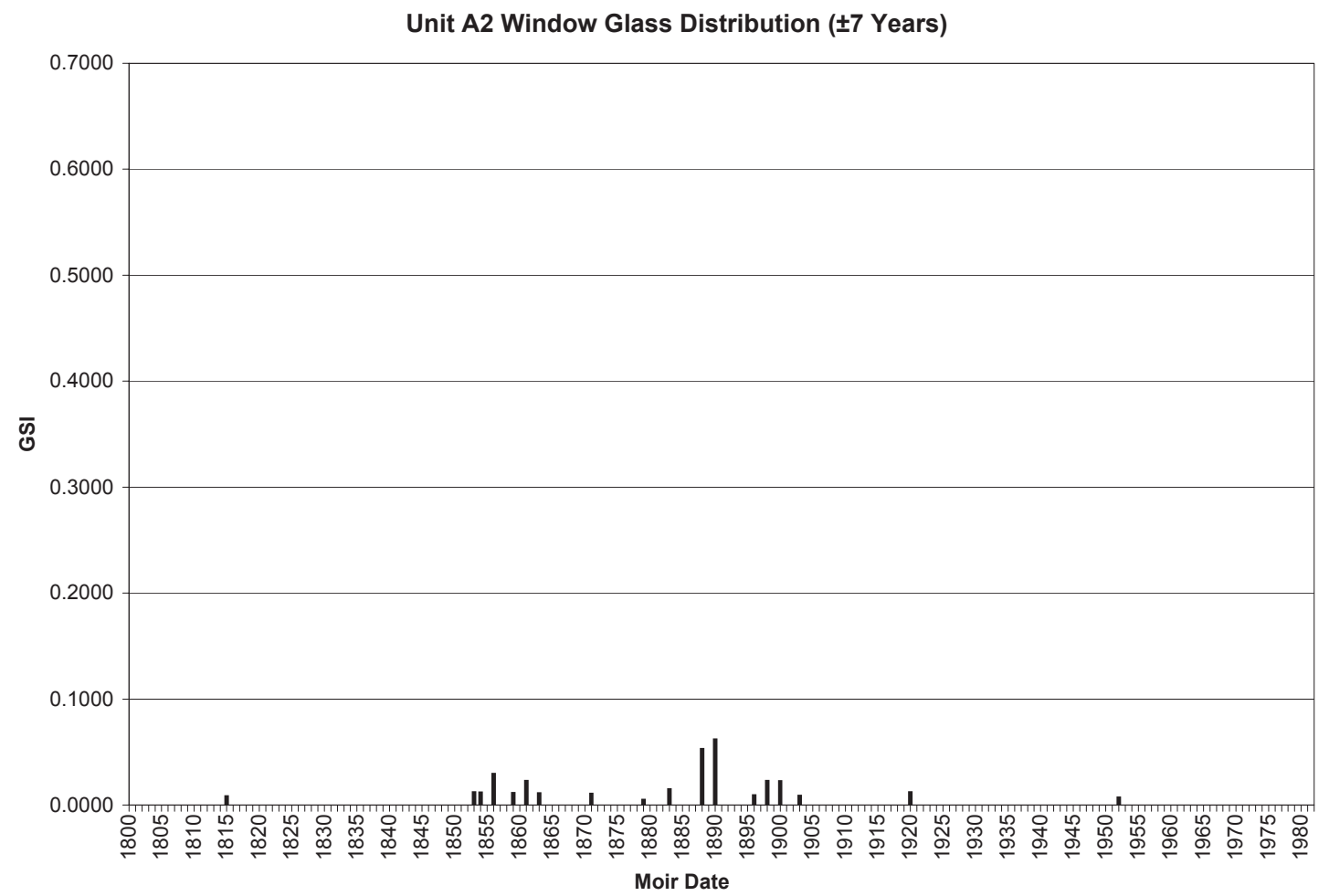

Figure A-9. Bar graph showing the temporal window glass distribution for Unit A2 at the Levi Jordan Plantation State Historical Site (41BO165). 
Unit A3 Window Glass Distribution ( \pm 7 Years)

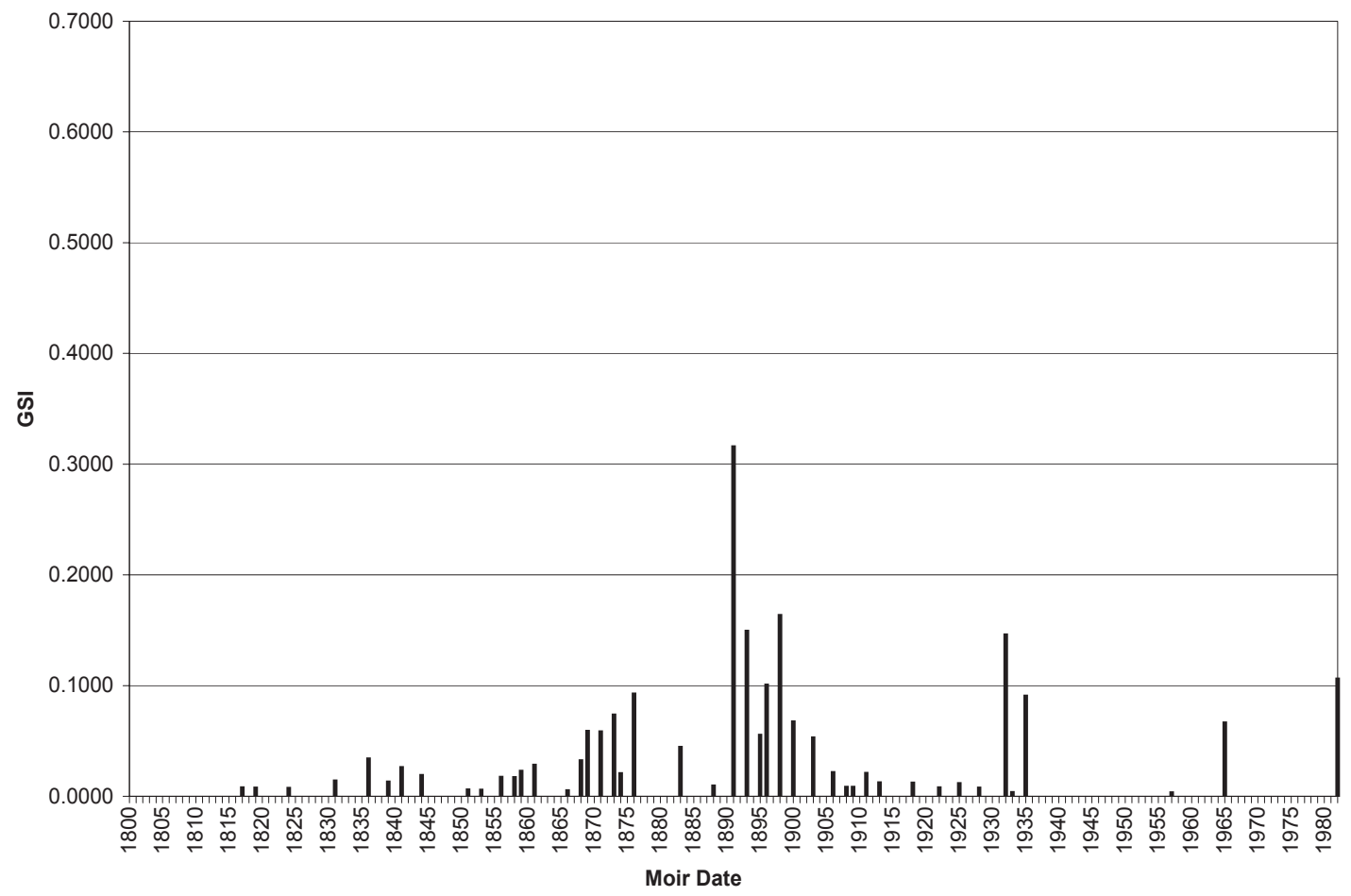

Figure A-10. Bar graph showing the temporal window glass distribution for Unit A3 at the Levi Jordan Plantation State Historical Site (41BO165).

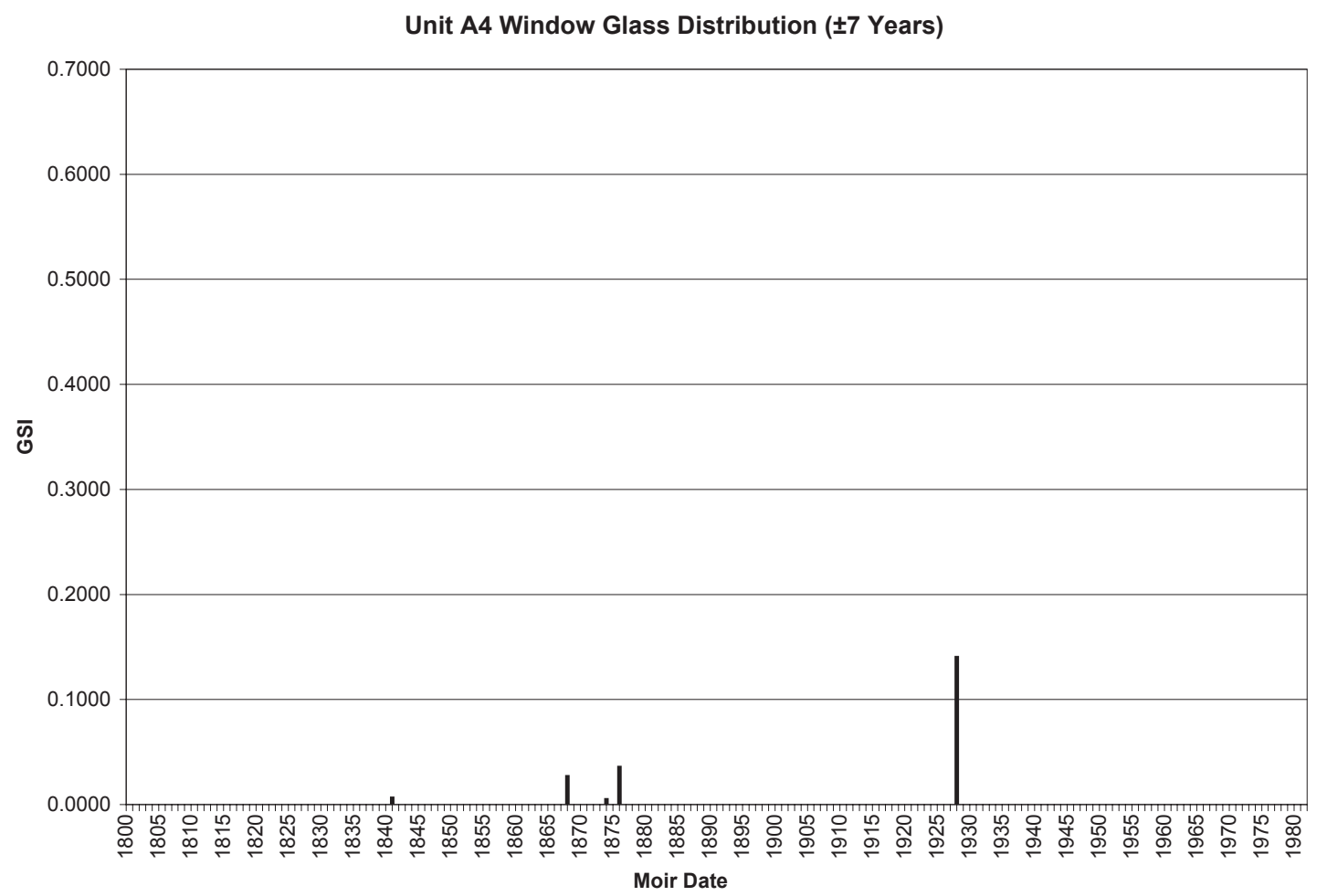

Figure A-11 Bar graph showing the temporal window glass distribution for Unit A4 at the Levi Jordan Plantation State Historical Site (41BO165). 
Unit A5 Window Glass Distribution ( \pm 7 Years)

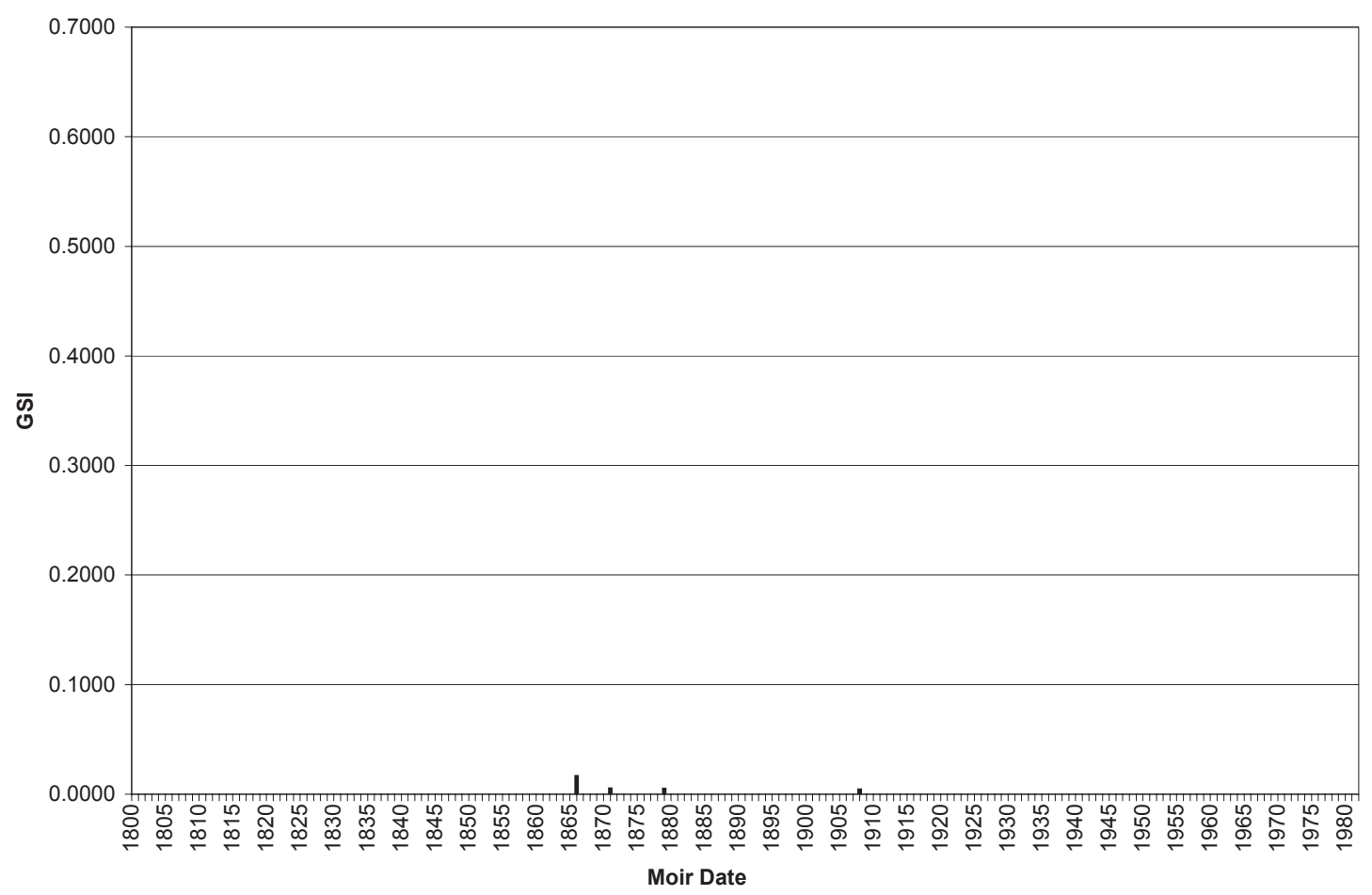

Figure A-12. Bar graph showing the temporal window glass distribution for Unit A5 at the Levi Jordan Plantation State Historical Site (41BO165). 
Unit B1 Window Glass Distribution ( \pm 7 Years)

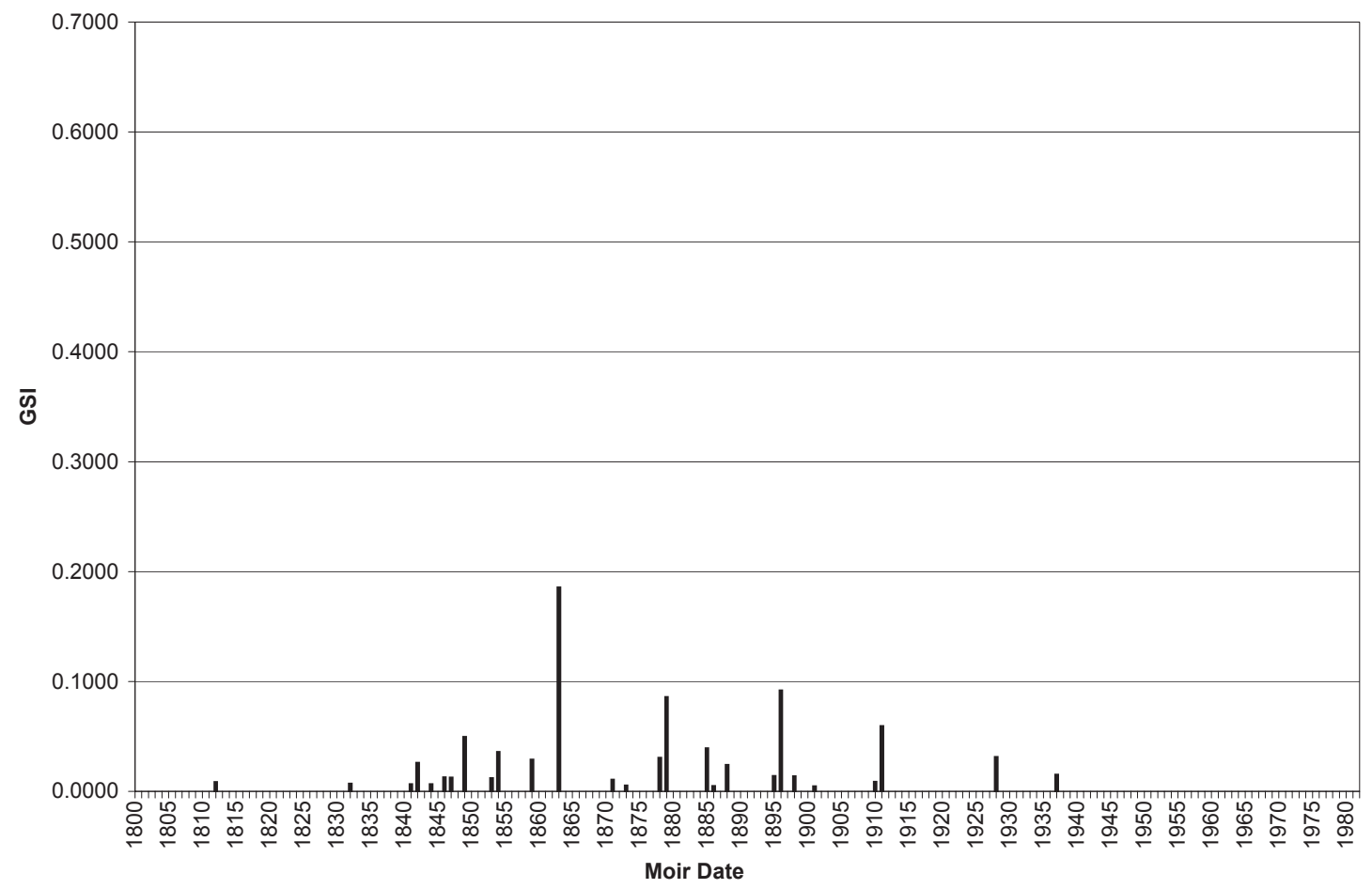

Figure A-13. Bar graph showing the temporal window glass distribution for Unit B1 at the Levi Jordan Plantation State Historical Site (41BO165).

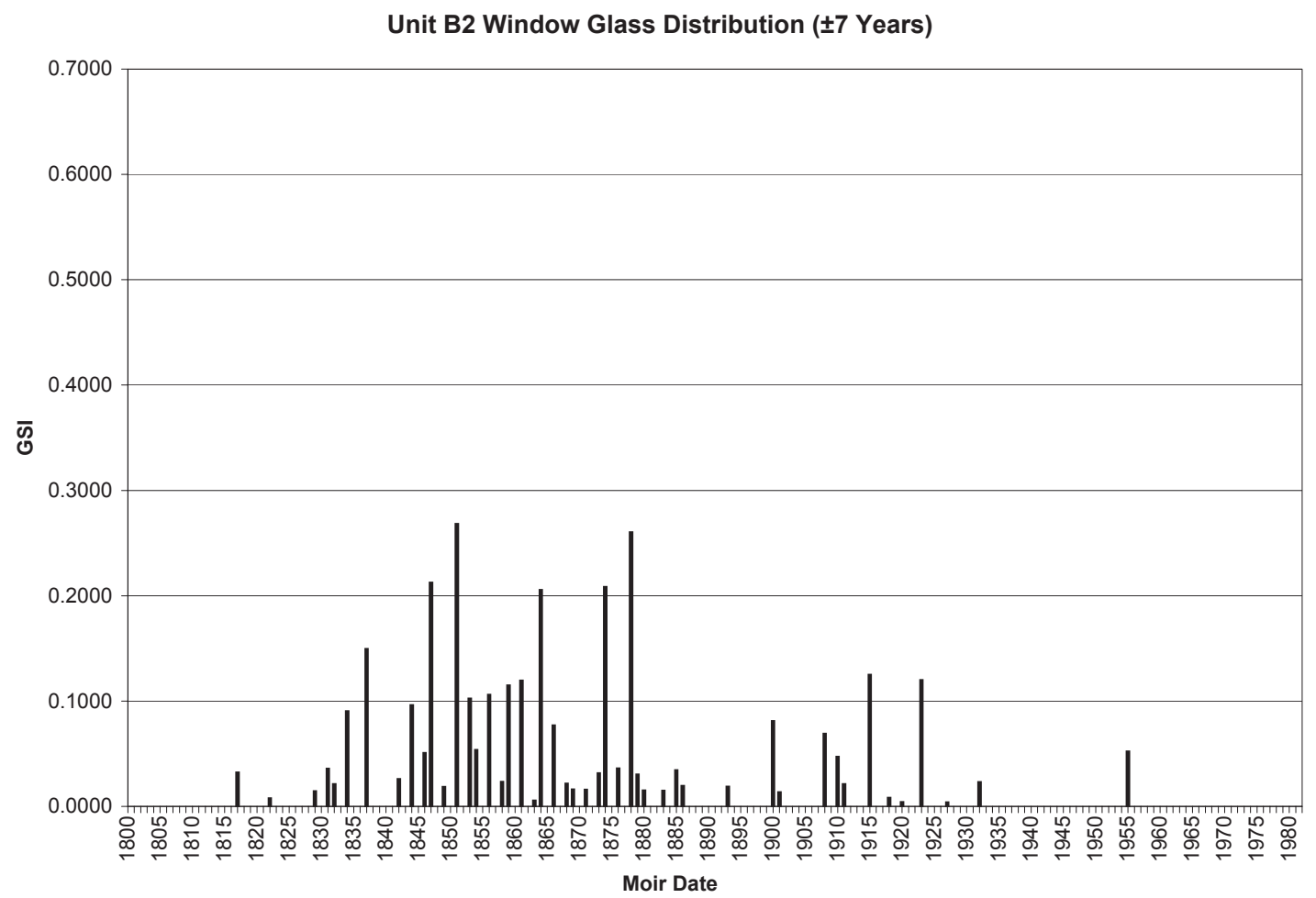

Figure A-14. Bar graph showing the temporal window glass distribution for Unit B2 at the Levi Jordan Plantation State Historical Site (41BO165). 


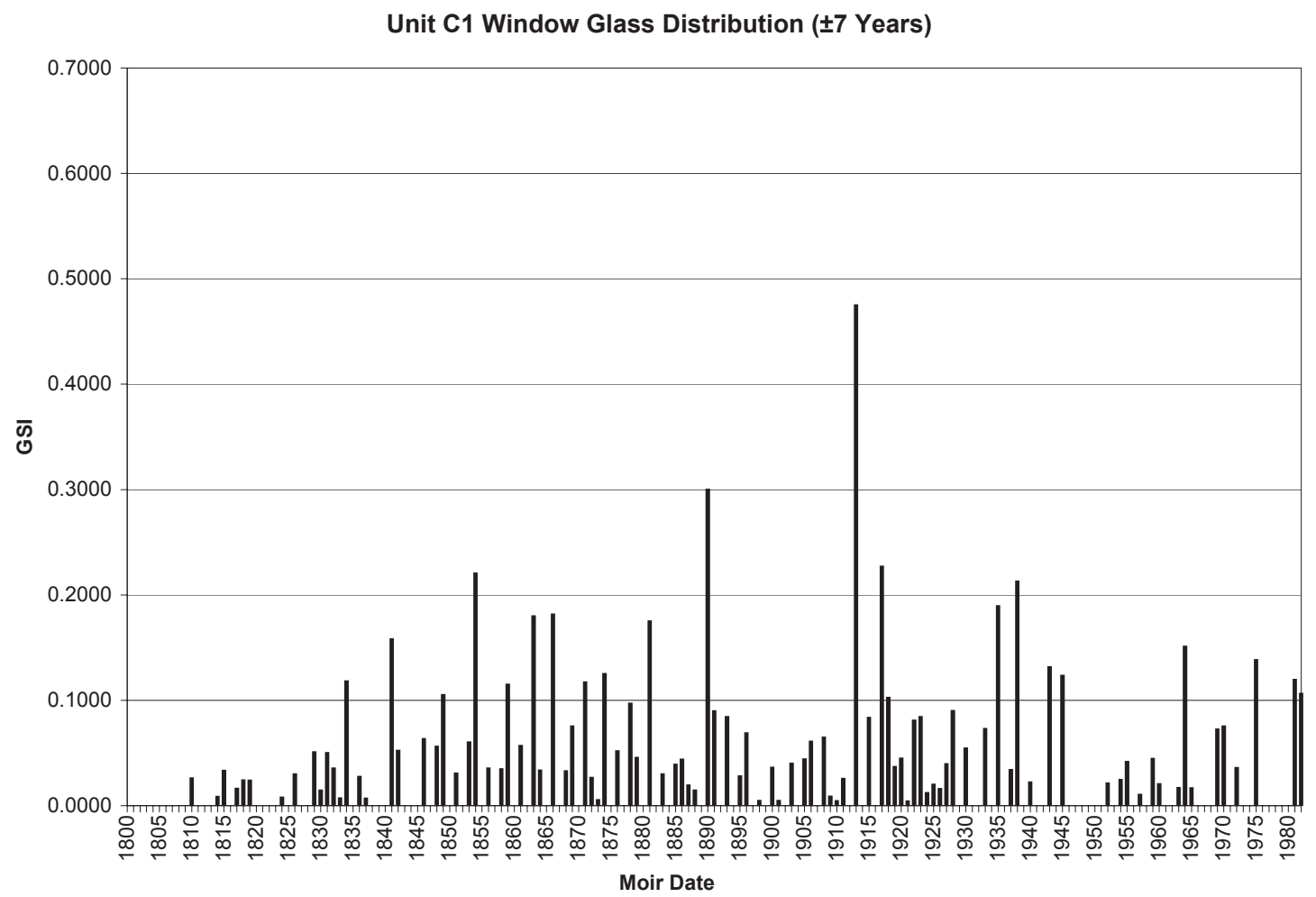

Figure A-15. Bar graph showing the temporal window glass distribution for Unit C1 at the Levi Jordan Plantation State Historical Site (41BO165).

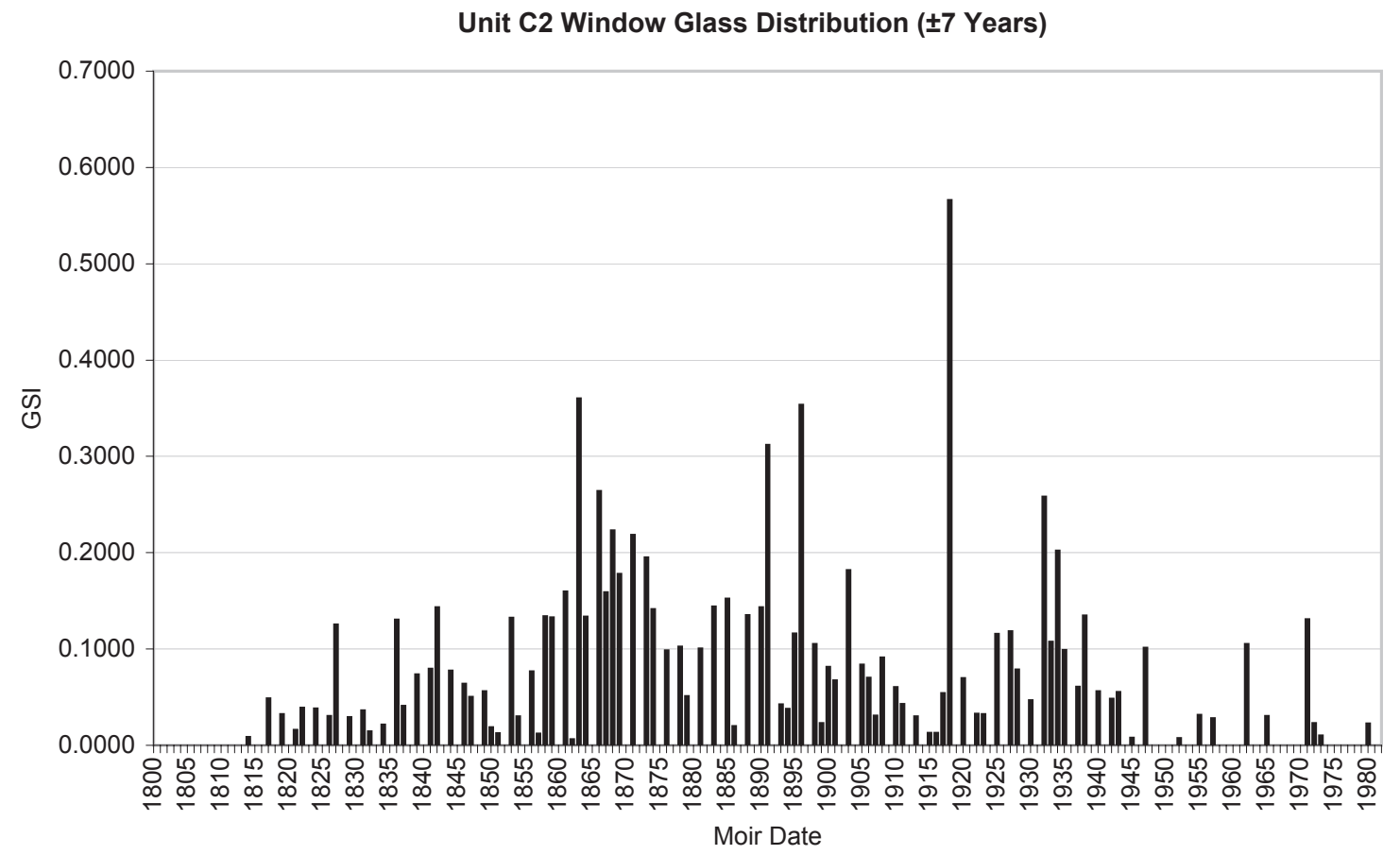

Figure A-16. Bar graph showing the temporal window glass distribution for Unit C2 at the Levi Jordan Plantation State Historical Site (41BO165). 
Unit D1 Window Glass Distribution ( \pm 7 Years)

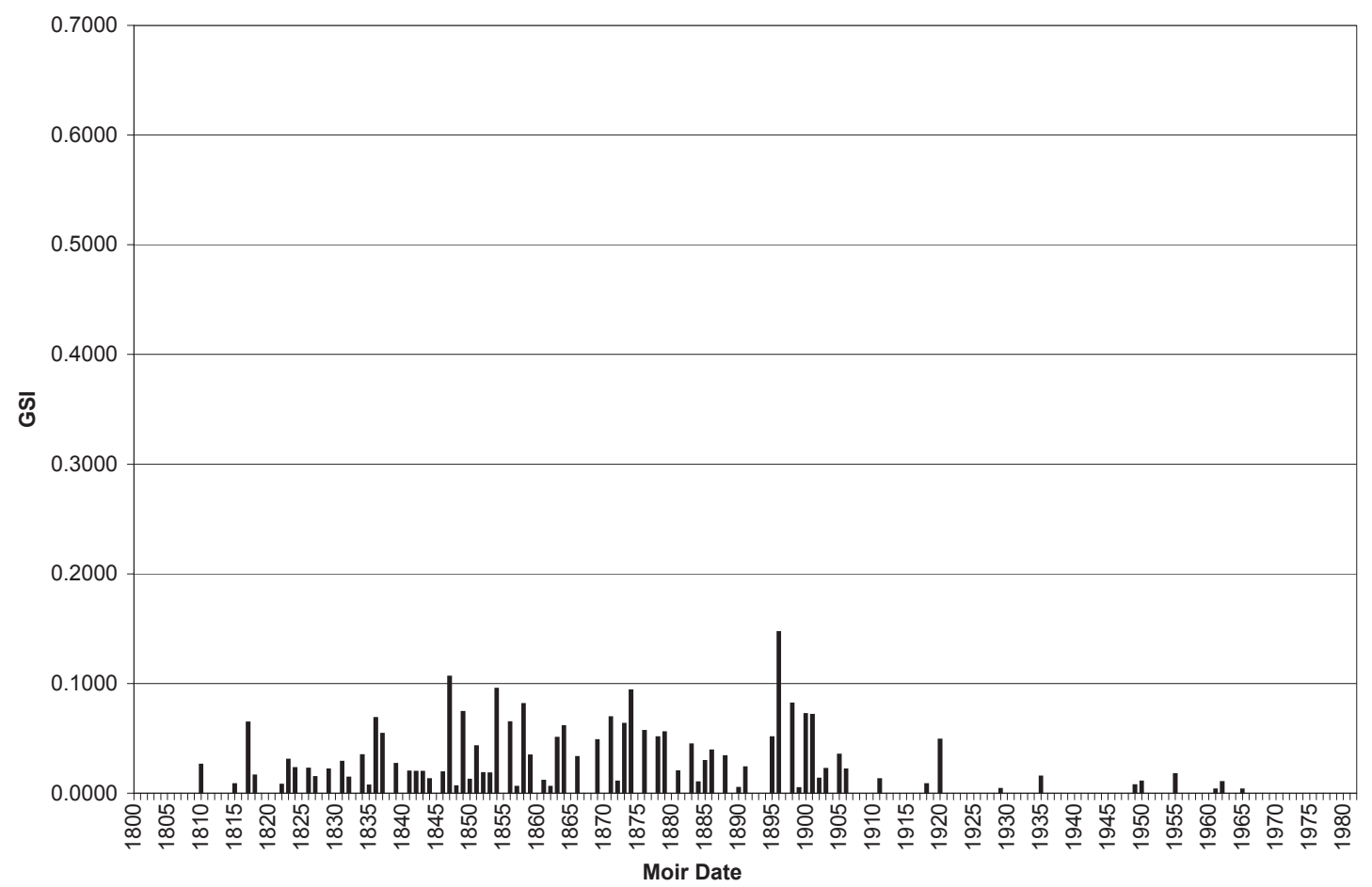

Figure A-17. Bar graph showing the temporal window glass distribution for Unit D1 at the Levi Jordan Plantation State Historical Site (41BO165).

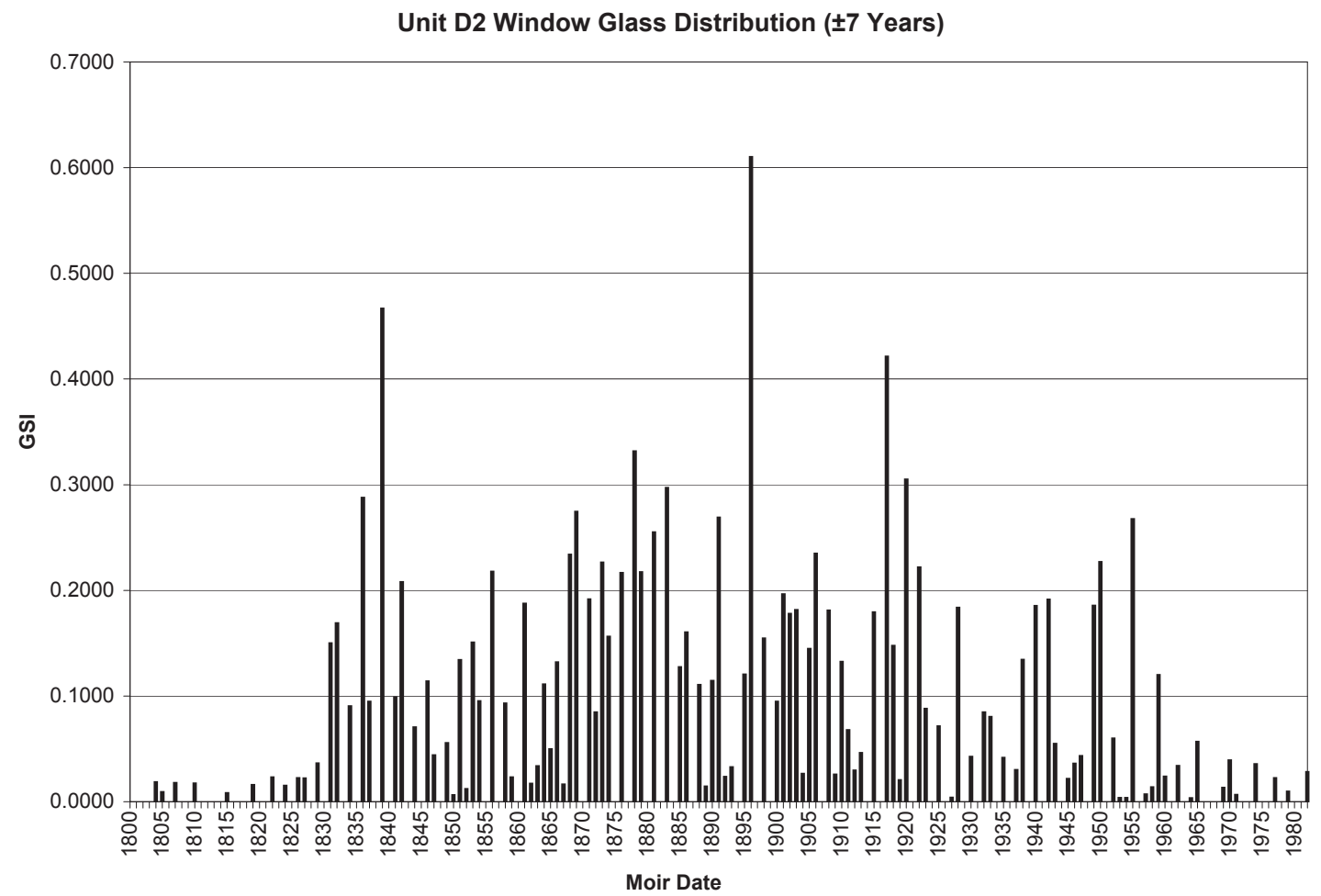

Figure A-18. Bar graph showing the temporal window glass distribution for Unit D2 at the Levi Jordan Plantation State Historical Site (41BO165). 


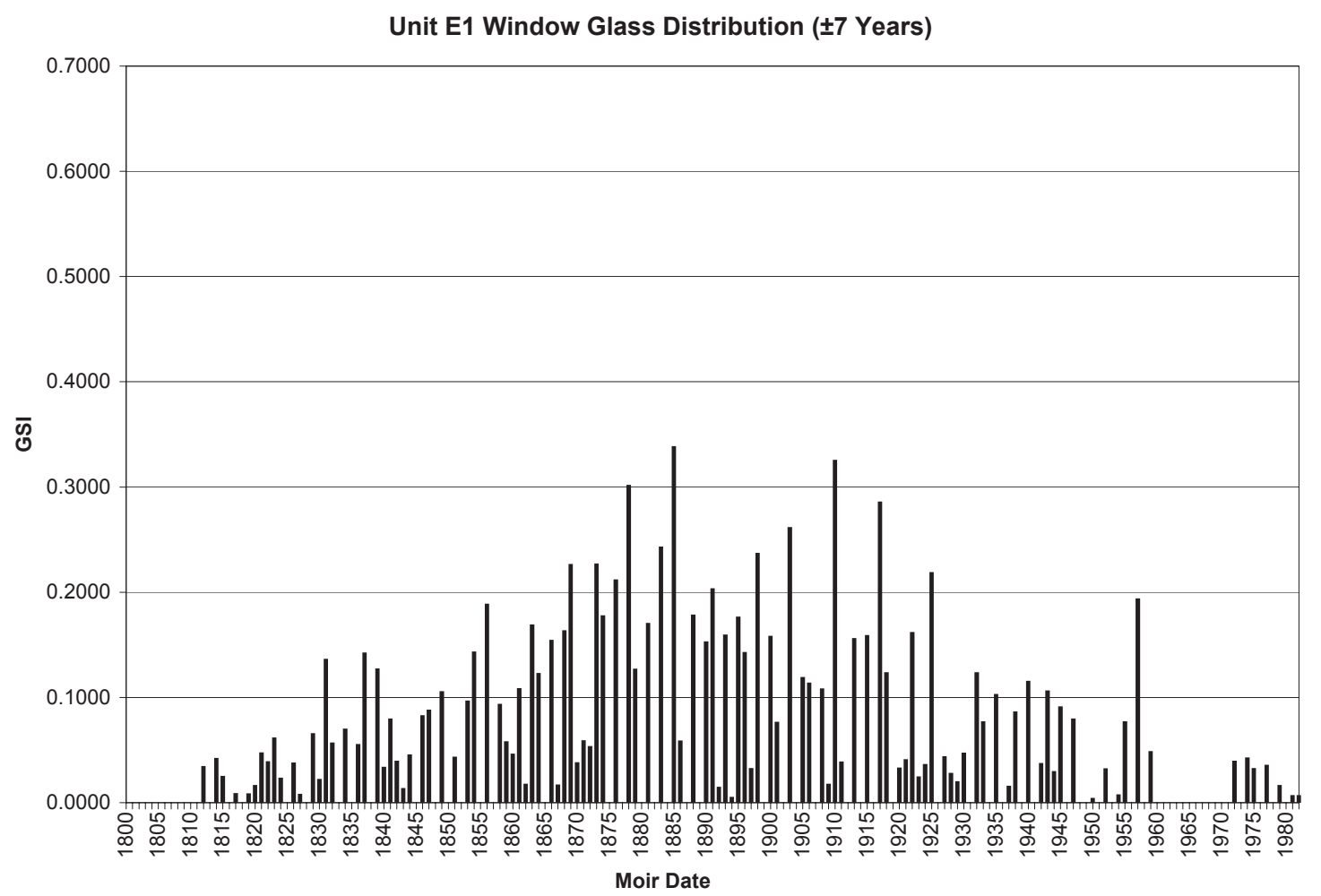

Figure A-19. Bar graph showing the temporal window glass distribution for Unit E1 at the Levi Jordan Plantation State Historical Site (41BO165).

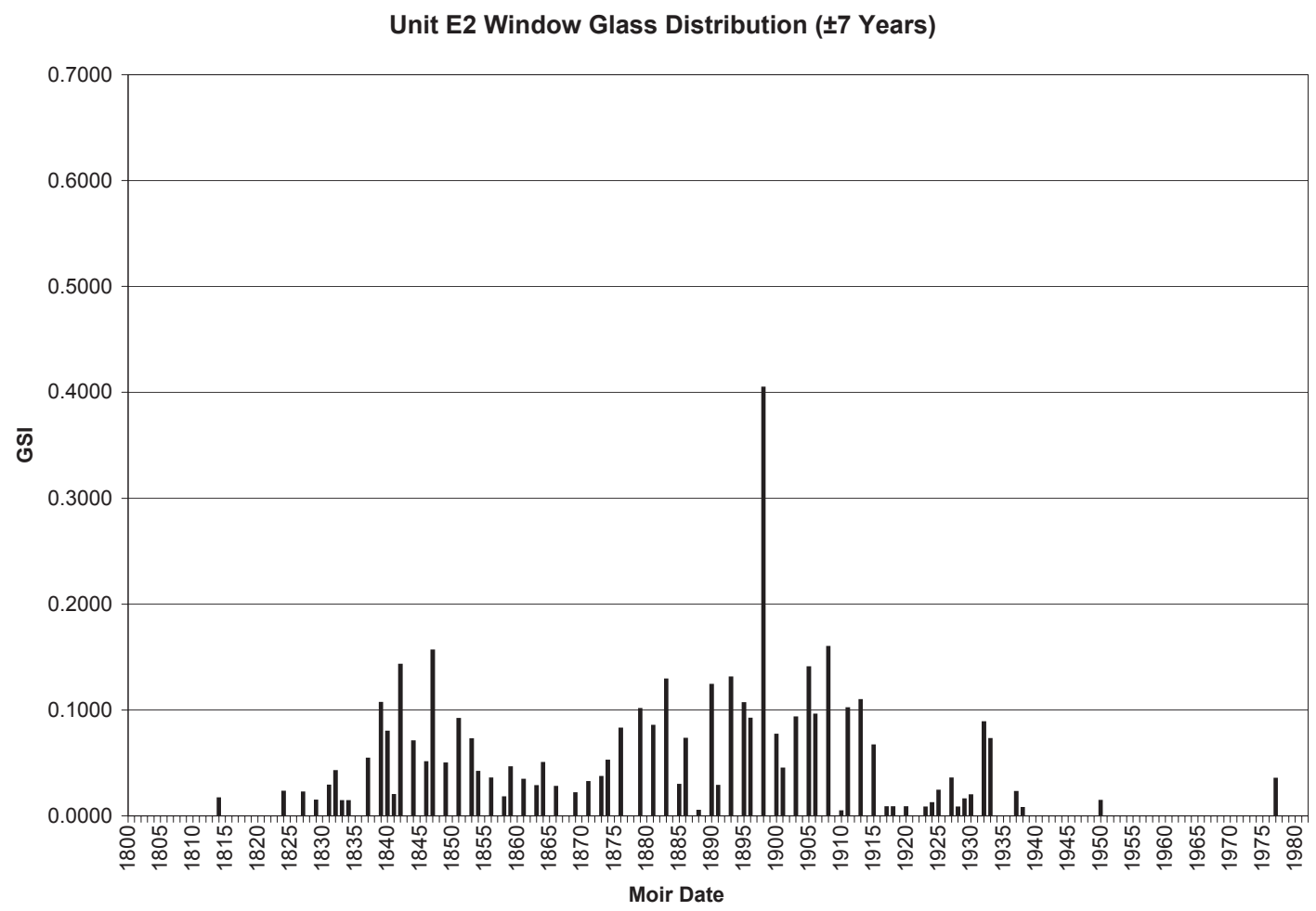

Figure A-20. Bar graph showing the temporal window glass distribution for Unit E2 at the Levi Jordan Plantation State Historical Site (41BO165). 


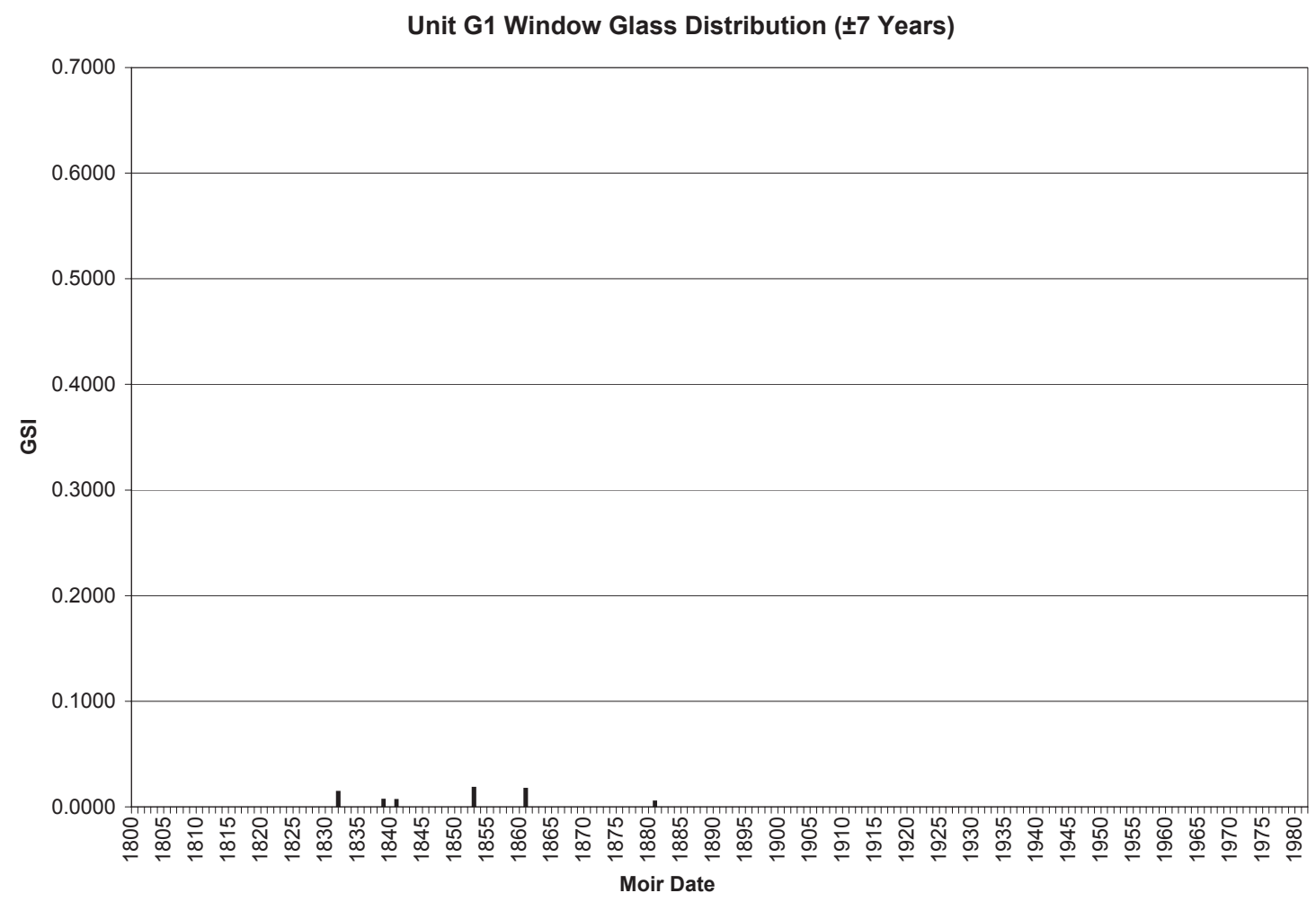

Figure A-21. Bar graph showing the temporal window glass distribution for Unit G1 at the Levi Jordan Plantation State Historical Site (41BO165). 


\section{Appendix B}

\section{Levi Jordan Plantation State Historic Site Artifact Classification System}

\section{Ceramics}

\begin{tabular}{|l|l|l|}
\hline Sub-Material & \multicolumn{1}{|c|}{ Artifact Class } & Artifact Class \\
\hline CA. Procelain & 1001. Plain Sherd & 1020. Door knob: decorated \\
\hline CB. Stoneware & 1002. Plain whole/rest. Vessel & 1021. Furniture hardware: plain \\
\hline CC. Earthenware & 1003. Decorated sherd (list) & 1022. Furniture hardware: decorated \\
\hline CD. Colonoware & 1004. Decorated whole/rest. Vessel & 1023. Tile fragment: plain \\
\hline CE. Bisque & 1005. Figurine: fragment & 1024. Tile fragment: decorated \\
\hline CF. China & 1006. Figurine: whole/rest. & 1025. Tile, whole/rest: plain \\
\hline CG. Kaolin & 1007. Doll: head/neck & 1026. Tile, whole/rest: decorated \\
\hline CH. Fired Clay & 1008. Doll: arm/hand & 1027. Brick fragment: plain \\
\hline CJ. Composite & 1009. Doll: body & 1028. Brick fragment: dec. (list) \\
\hline CK. Burned Sand & 1010. Doll: leg/foot & 1029. Brick, whole/rest: plain \\
\hline & 1011. Doll: whole/rest. & 1030. Brick, whole/rest: dec (list) \\
\hline & 1012. Button: plain & 1031. Mortar \\
\hline & 1013. Button: decorated (list type) & 1032. Tabby \\
\hline & 1014. Stopper: round & 1033. Indeterminate \\
\hline & 1015. Pipe bowl: plain & \\
\hline & 1016. Pipe bowl: decorated (list type) & \\
\hline & 1017. Pipe stem: plain & \\
\hline & 1018. Pipe stem: decorated & \\
\hline & 1019. Door knob: plain & \\
\hline & & \\
\hline
\end{tabular}




\section{Glass}

\begin{tabular}{|c|c|c|}
\hline Sub-Material & Artifact Class & Artifact Class \\
\hline GA. Clear & 2001. Flat, no backing: plain & 2027. Cylindrical bead: plain \\
\hline GB. Red & 2002. Flat, no backing: dec. & 2028. Cylindrical bead: dec \\
\hline GC. Green & 2003. Flat, mirrored: plain & 2029. Seed bead \\
\hline GD. Blue & 2004. Flat, mirrored: dec & 2030. Cut glass (list type) \\
\hline GE. Amber & 2005. Curved: plain & 2031. Tube: plain \\
\hline GF. Brown & 2006. Curved: decorated & 2032. Tube: decorated \\
\hline GG. Black & 2007. Bottle rim: plain & 2033. Round. Bottle stopper: plain \\
\hline GH. White & 2008. Bottle rim: dec. & 2034. Round bottle stopper: dec. \\
\hline GI. Violet & 2009. Bottle base: plain & 2035. Cut glass bottle stopper \\
\hline GJ. Aqua & 2010. Bottle base: dec. & 2036. Marble: plain \\
\hline GK. Olive & 2011. Tableware rim: plain & 2037. Marble: dec. \\
\hline GL. Opaque & 2012. Tableware rim: dec. & 2038. Eyeglass lens (list shape) \\
\hline \multirow[t]{14}{*}{ GM. Pink } & 2013. Tableware base: plain & 2039. Doorknob: plain \\
\hline & 2014. Tableware base: dec & 2040. Doorknob: dec. \\
\hline & 2015. Kitchenware rim: plain & 2041. Worked fragments (list type) \\
\hline & 2016. Kitchenware rim: dec. & 2042. Whole bottle \\
\hline & 2017. Kitchenware base: plain & 2043. Melted fragment \\
\hline & 2018. Kitchenware base: dec. & 2044. Chimney glass \\
\hline & 2019. Button: plain & 2045. Light, modern \\
\hline & 2020. Button: dec. & 2046. Bottle, body: plain \\
\hline & 2021. Hair pin: plain & 2047. Bottle, body: dec. \\
\hline & 2022. Hair pin: dec. & 2048. Jar lid \\
\hline & 2023. Tubular bead: plain & 2049. Tableware body: plain \\
\hline & 2024. Tubular bead: dec. & 2050. Tableware body: dec \\
\hline & 2025. Spherical bead: plain & \\
\hline & 2026. Spherical bead: dec. & \\
\hline
\end{tabular}




\section{Metal}

\begin{tabular}{|c|c|c|}
\hline Sub-Material & Artifact Class & Artifact Class \\
\hline MA. Iron/Steel & 3001. Square nail: wrought & 3039. Ring: small \\
\hline MB. Copper/Brass & 3002. Square nail: wire & 3040. Ring: medium \\
\hline MC. Gold & 3003. Square nail: indeter. & 3041. Ring: large \\
\hline MD. Silver & 3004. Square spike: wrought & 3042. Hardware: hinge/plate \\
\hline ME. Lead & 3005. Square spike: other & 3043. Hardware: latch \\
\hline MF. Pewter/Tin & 3006. Round nail & 3044. Hardware: handle/knob \\
\hline MG. Enamel/Tin ware & 3007. Round spike & 3045. Hardware: lock plate \\
\hline MH. Aluminum & 3008. Indeterminate nail & 3046. Hardware: key \\
\hline \multirow[t]{30}{*}{ MI. Indeterminate } & 3009. Square tack & 3047. Hardware: grid screen \\
\hline & 3010. Round tack & 3048. Hardware: perforated screen \\
\hline & 3011. Indeterminate tack & 3049. Hardware: indeterminate \\
\hline & 3012. Screw & 3050. File: round \\
\hline & 3013. Hook & 3051. File: half-round \\
\hline & 3014. Eye & 3052. File: triangular \\
\hline & 3015. Bolt & 3053. File: rectangular \\
\hline & 3016. Staple: small & 3054. Hoe \\
\hline & 3017.Staple: large & 3055. Hammer \\
\hline & 3018. Washer & 3056. Ax \\
\hline & 3019. Nut & 3057. Hatchet \\
\hline & 3020. Rivet: clothing & 3058. Plow \\
\hline & 3021. Rivet: leather & 3059. Awl \\
\hline & 3022. Rivet: other & 3060. Plane bit \\
\hline & 3023. Needle & 3061. Drill bit \\
\hline & 3024. Pin: straight & 3062. Drill part \\
\hline & 3025. Pin: safety & 3063. Chisel \\
\hline & 3026. Clothing hook & 3064. Saw blade \\
\hline & 3027. Clothing eye & 3065. Knife blade: pocket \\
\hline & 3028. Buckle: belt & 3066. Knife blade: straight \\
\hline & 3029. Buckle: shoe & 3067. Screwdriver \\
\hline & 3030. Buckle: harness & 3068. Pulley: frame \\
\hline & 3031. Buckle: indeterminate & 3069. Pulley: wheel \\
\hline & 3032. Button: plain & 3070. Pulley: pin \\
\hline & 3033. Button: decorated & 3071. Scissors \\
\hline & 3034. Wire: square & 3072. Spring \\
\hline & 3035. Wire: round & 3073. Thimble \\
\hline & 3036. Wire: barbed & 3074. Eyeglasses/frames \\
\hline & 3037. Chain: small link & 3075. Box: round \\
\hline & 3038. Chain: large link & 3076. Box: rectangular \\
\hline
\end{tabular}




\section{Metal (continued)}

\begin{tabular}{|c|c|c|}
\hline Sub-Material & Artifact Class & Artifact Class \\
\hline MA. Iron/Steel & 3077. Shackle & 3113. Munitions: rim fire casing \\
\hline MB. Copper/Brass & 3078. Indeterminate tool & 3114. Munitions: center fire casing \\
\hline MC. Gold & 3079. Vessel fragment: handle & 3115. Munitions: powder cap \\
\hline MD. Silver & 3080. Vessel fragment: body & 3116. Munitions: bullet (list cal.) \\
\hline ME. Lead & 3081. Vessel fragment: base & 3117. Munitions: shot size \\
\hline MF. Pewter/Tin & 3082. Vessel fragment: support & 3118. Munitions: bullet mold \\
\hline $\begin{array}{l}\text { MG. Enamel/ } \\
\text { Tin ware }\end{array}$ & 3083. Vessel fragment: cover & 3121. Munitions: melted lead \\
\hline MH. Aluminum & 3084. Vessel fragment: plate & 3122. Horseshoe: small \\
\hline \multirow[t]{28}{*}{ MI. Indeterminate } & 3085. Vessel fragment: saucer & 3123. Horseshoe: large \\
\hline & 3086. Vessel fragment: cup/mug & 3124. Harness bit \\
\hline & 3087. Vessel fragment: bowl & 3125. Curry comb \\
\hline & 3088. Vessel fragment: serving & 3126. Curb chain \\
\hline & 3089. Indet. Vessel fragment & 3127. Wheel part: hub \\
\hline & 3090. Complete vessel (list) & 3128. Wheel part: spoke \\
\hline & 3091. Utensil: knife & 3129. Wheel part: runner \\
\hline & 3092. Utensil: fork & 3130. Wagon rigging \\
\hline & 3093. Spoon & 3131. Machine part: small gear \\
\hline & 3094. Utensil: indeterminate & 3132. Machine part: large gear \\
\hline & 3095. Hearth fixture: swinging crane & 3133. Machine part: small wheel \\
\hline & 3096. Hearth fixture: grate & 3134. Machine part: large wheel \\
\hline & 3097. Hearth fixture: tongs & 3135. Machine part: housing \\
\hline & 3098. Hearth fixture: poker & 3136. Pipe/tube \\
\hline & 3099. Hearth fixture: hook & 3137. Jewelry: light chain \\
\hline & 3100. Can opener, key & 3138. Jewelry: heavy chain \\
\hline & 3101. Can: round & 3139. Jewelry: broach \\
\hline & 3102. Can: rectangular & 3140. Jewelry: pendant \\
\hline & 3103. Can: indeterminate & 3141. Jewelry: pendant w/glass \\
\hline & 3104. Toy: gun & 3142. Jewelry: pendant w/other \\
\hline & 3105. Toy: cast figure & 3143. Jewelry: earring \\
\hline & 3106. Toy: jack & 3144. Jewelry: earring, cut glass \\
\hline & 3107. Toy: wheel & 3145. Jewelry: earring, other \\
\hline & 3108. Toy: vehicle & 3146. Jewelry: ring, plain \\
\hline & 3109 Musical instrument: mouth organ & 3147. Jewelry: ring, decorated \\
\hline & 3110. Musical instrument: harmonica & 3148 Jewelry: ring, cut glass \\
\hline & 3111. Munitions: gun part (list) & 3149. Jewelry: ring, other (list) \\
\hline & 3112. Munitions: complete gun (list) & 3150. Jewelry: watch \\
\hline
\end{tabular}




\section{Metal (continued)}

\begin{tabular}{|l|l|l|}
\hline \multicolumn{1}{|c|}{ Sub-Material } & \multicolumn{1}{c|}{ Artifact Class } & \multicolumn{1}{c|}{ Artifact Class } \\
\hline MA. Iron/Steel & 3151. Jewelry: bracelet, plain & 3166. Token: partial (list) \\
\hline MB. Copper/Brass & 3152. Jewelry: bracelet, dec. & 3167. Token: complete (list) \\
\hline MC. Gold & 3153. Jewelry: bracelet, cut glass & 3168. Hair comb, body \\
\hline MD. Silver & 3154. Jewelry: bracelet, other & 3169. Hair comb, tooth \\
\hline ME. Lead & 3155. Jewelry: tubular bead, pln & 3170. Hair pin \\
\hline MF. Pewter/Tin & 3156. Jewelry: tubular bead, dec & 3171. Bottle cap: sides crimped \\
\hline $\begin{array}{l}\text { MG. Enamel/ } \\
\text { Tin ware }\end{array}$ & 3157. Jewelry: spherical bead, pln & 3172. Bottle cap: screw sides \\
\hline MH. Aluminum & 3158. Jewelry: spherical bead, dec & 3173. Flat metal fragment: flake \\
\hline MI. Indeterminate & 3159. Jewelry: cylindrical bead, pln & 3174. Flat metal fragment: band \\
\hline & 3160. Jewelry: cylindrical bead, dec & 3175. Thick flat metal fragment \\
\hline & 3161. Jewelry: wire & 3176. Indeterminate \\
\hline & 3162. Jewelry: thread & 3177. Modern \\
\hline & 3163. Coin: Partial (list) & 3178. Munitions: shot gun shell \\
\hline & 3164. Coin: complete (list) & 3179. Munitions: percussion \\
\hline & 3165. Coin: pierced (list) & 3180. Square nail: machine made \\
\hline
\end{tabular}

\section{Rubber}

\begin{tabular}{|l|l|l|}
\hline \multicolumn{1}{|c|}{ Sub-Material } & \multicolumn{1}{|c|}{ Artifact Class } & \multicolumn{1}{c|}{ Artifact Class } \\
\hline RA. Soft & 4001. Comb: tooth & 4008. Jar sealer: solid \\
\hline RB. Vulcanized & 4002. Comb: body w/teeth & 4009. Machine belt \\
\hline RC. Composite & 4003. Comb: body w/o teeth & 4010. Tire fragment \\
\hline & 4004. Button: plain & 4011 Indeterminate \\
\hline & 4005. Button: decorated & 4012. Modern (list) \\
\hline & 4006. Collar stay & 4013. Shingle \\
\hline & 4007. Jar sealer: washer & \\
\hline
\end{tabular}




\section{Lithics}

\begin{tabular}{|l|l|l|}
\hline Sub-Material & \multicolumn{1}{|c|}{ Artifact Class } & \multicolumn{1}{|c|}{ Artifact Class } \\
\hline LA. Flint/Chert & 5001. Unmodified stone & 5011. Mortar \\
\hline LB. Quartz & 5002. Gun flint & 5012. Pestle \\
\hline LC. Quartzite & 5003. Marble, plain & 5013. Metate \\
\hline LD. Sulfur & 5004. Marble, decorated (list) & 5014. Mano \\
\hline LE. Sandstone & 5005. Projectile point (list) & 5015. Pencil \\
\hline LF. Limestone & 5006. Scraper (list) & 5016. Broad, flat \\
\hline LG. Granite & 5007. Unworked flake & 5017. Indeterminate \\
\hline LH. Slate & 5008. Worked flake & 5018. Caliché \\
\hline LI. Indeterminate & 5009. Blade & 5019. Caliché w/wire \\
\hline LJ. Soapstone & 5010. Core & \\
\hline LK. Caliché & & \\
\hline
\end{tabular}

\section{Ecology}

\begin{tabular}{|l|l|l|}
\hline \multicolumn{1}{|c|}{ Sub-Material } & \multicolumn{1}{c|}{ Artifact Class } & \multicolumn{1}{c|}{ Artifact Class } \\
\hline EA. Bird & 6001. Unmodified bone & 6021. Harmonica plate \\
\hline EB. Mammal, non-human & 6002. Unmodified egg shell & 6022. Jewelry, pendent \\
\hline EC. Human & 6003. Unmodified tooth & 6023. Jewelry, ring \\
\hline ED. Fish & 6004. Unmodified scale & 6024. Jewelry pin \\
\hline EE. Reptile/Amphibian & 6005. Unmodified shell & 6025. Shaped inlay \\
\hline EF. Shellfish (saltwater) & 6006. Unmodified seed pod & 6026. Drilled shell, plain \\
\hline EG. Shellfish (freshwater) & 6007. Unmodified nut shell & 6027. Drilled shell, decorated \\
\hline EH. Shellfish (land) & 6008. Unmodified wood & 6028. Antler tool \\
\hline EI. Crustacean & 6009. Button, plain & 6029. Tooth, modified (list) \\
\hline EJ. Plant (wood) & 6010. Button, decorated & 6030. Utensil handle, plain \\
\hline EK. Raw Clay & 6011. Awl & 6031. Utensil handle, decorated \\
\hline EL. Coral & 6012. Scraper & 6032. Charcoal \\
\hline EM. Coal & 6013. Graver & 6033. Indeterminate, modified \\
\hline EN. Indeterminate & 6014. Pin, straight & 6034. Indeterminate, unmodified \\
\hline EO. Chalk & 6015. Spoon & 6035. Slag \\
\hline & 6016. Toothbrush handle & 6036. Jewelry, bead \\
\hline & 6017. Toothbrush head & 6037. Cut bone \\
\hline & 6018. Comb, body & 6038. Chalk \\
\hline & 6019. Comb, tooth & 6039. Unmodified claw \\
\hline & 6020. Hair pin & \\
\hline
\end{tabular}




\section{Miscellaneous}

\begin{tabular}{|l|l|l|}
\hline \multicolumn{1}{|c|}{ Sub-Material } & \multicolumn{1}{c|}{ Artifact Class } & \multicolumn{1}{c|}{ Artifact Class } \\
\hline SA. Textile & 8001. Modern & 8006. Button \\
\hline SB. Plastic & 8002. Cloth/Fabric/Fiber & 8007. Window Screen \\
\hline SC. Synthetic & 8003. Indeterminate & 8008. Comb \\
\hline SD. Fiberglass & 8004. String/Yarn/Thread & 8009. Paper/Cardboard \\
\hline SE. Indeterminate & 8005. Toy & \\
\hline SF. Nylon & & \\
\hline SG. Leather & & \\
\hline
\end{tabular}




\section{Appendix C \\ Levi Jordan Plantation State Historic Site Artifact Catalogue}

\begin{tabular}{|l|l|}
\hline Abbreviation & Definition \\
\hline IIR & illustrated in report \\
\hline poss. & possible \\
\hline Spec. & specimen \\
\hline ST & shovel test \\
\hline Feat & feature \\
\hline Mat & material \\
\hline Dec & decoration \\
\hline Ct & count \\
\hline Wt & weight \\
\hline
\end{tabular}




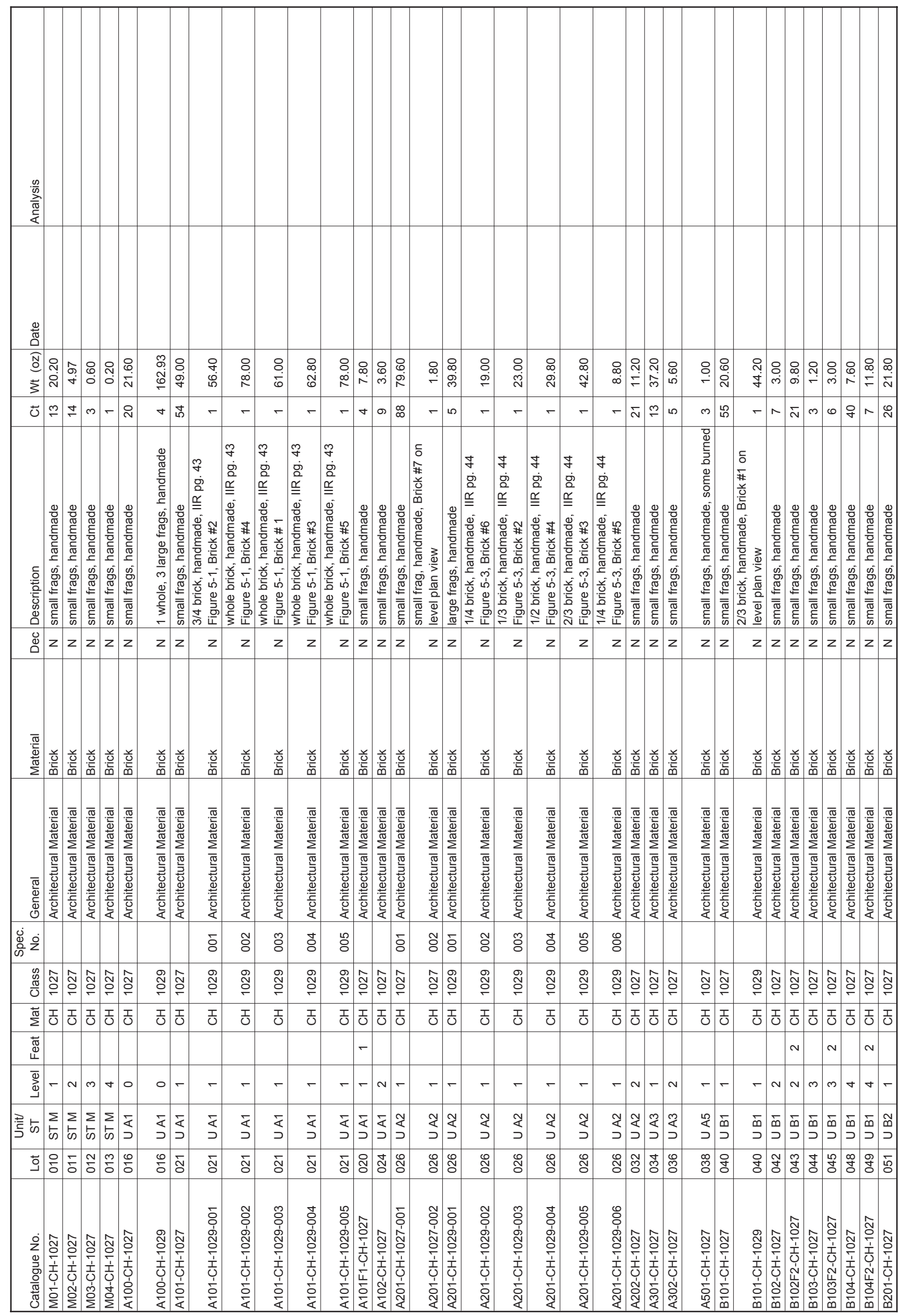




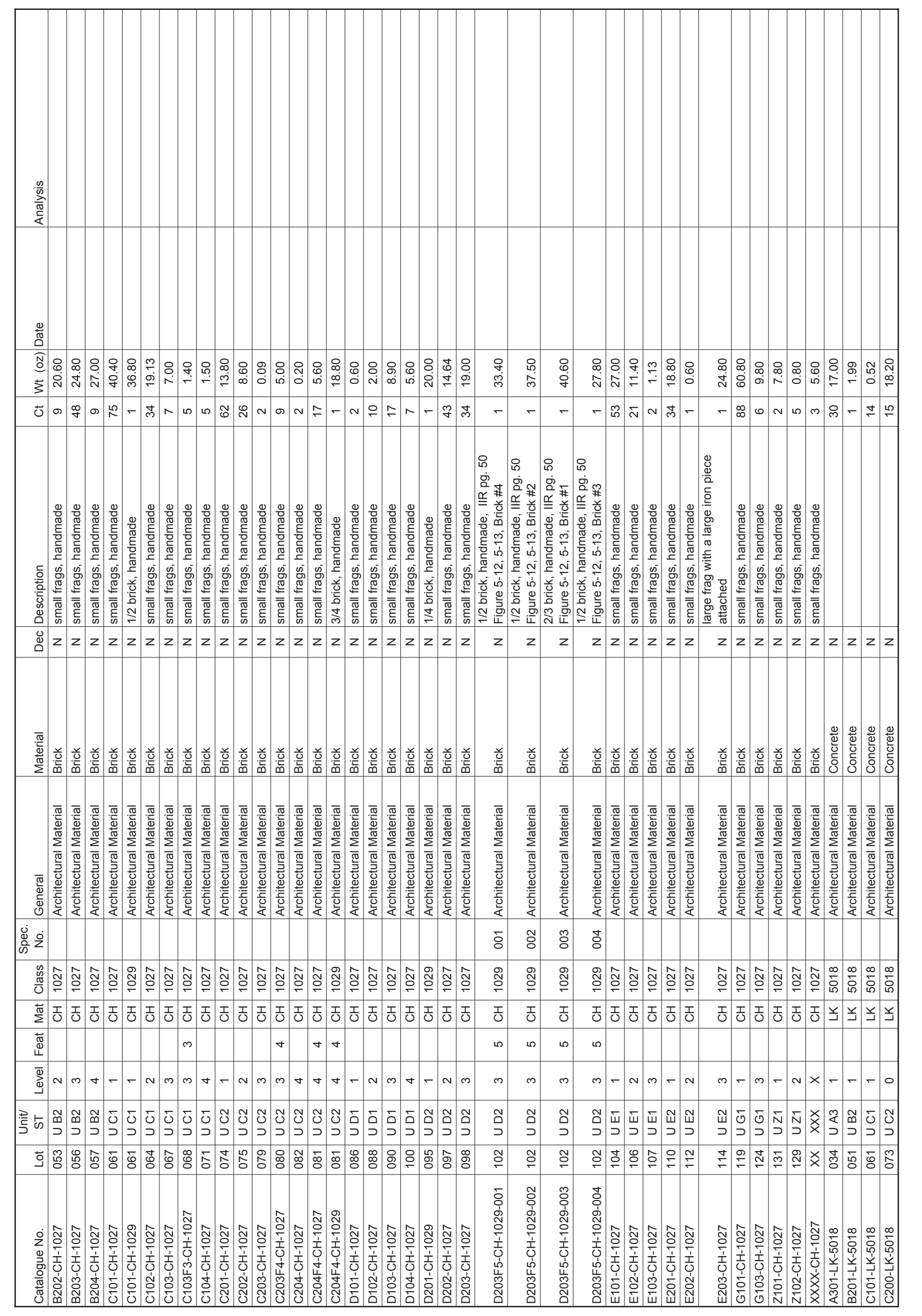




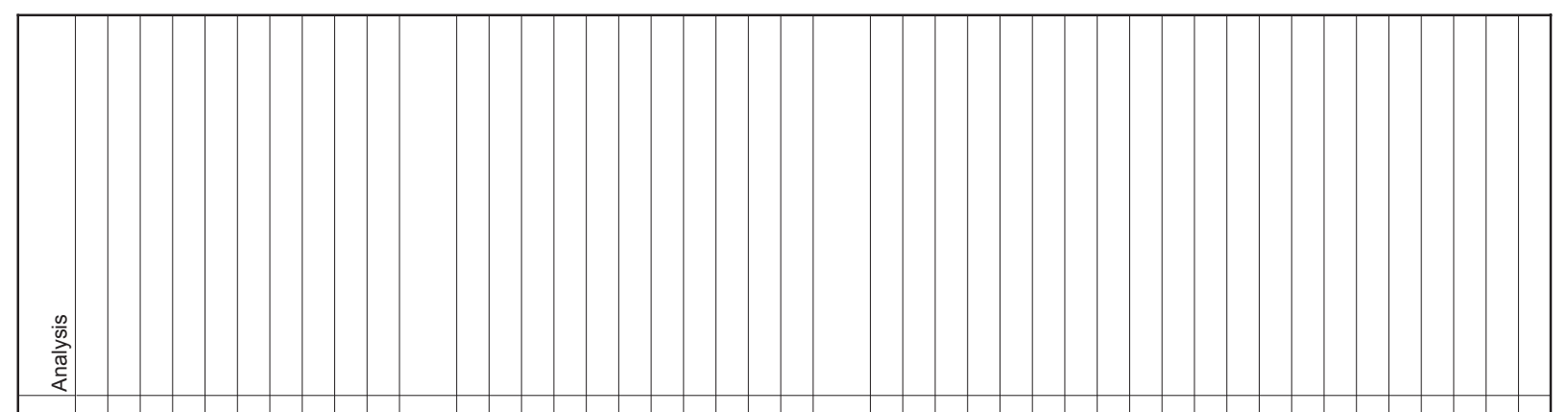

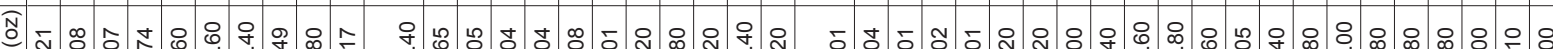

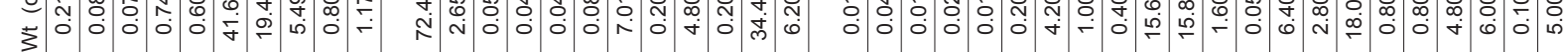

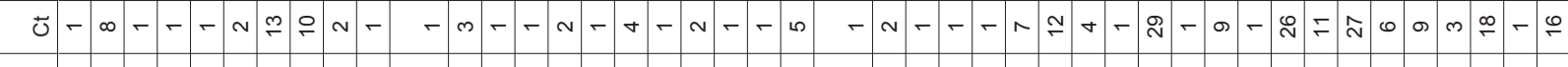

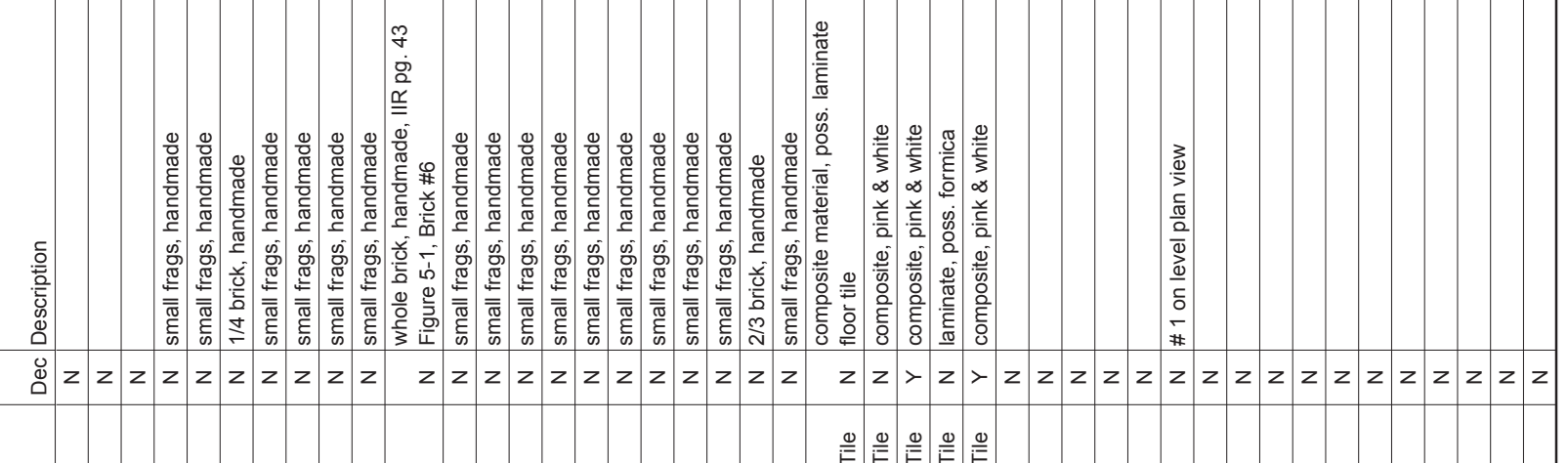

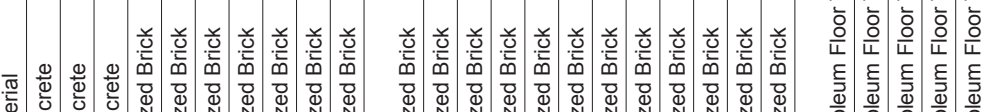

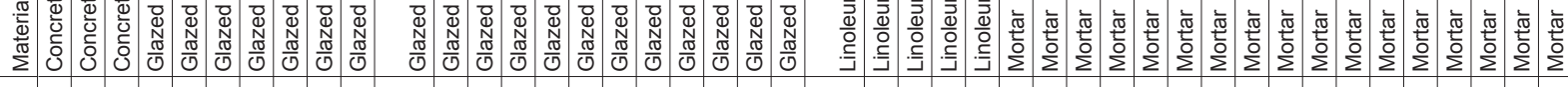

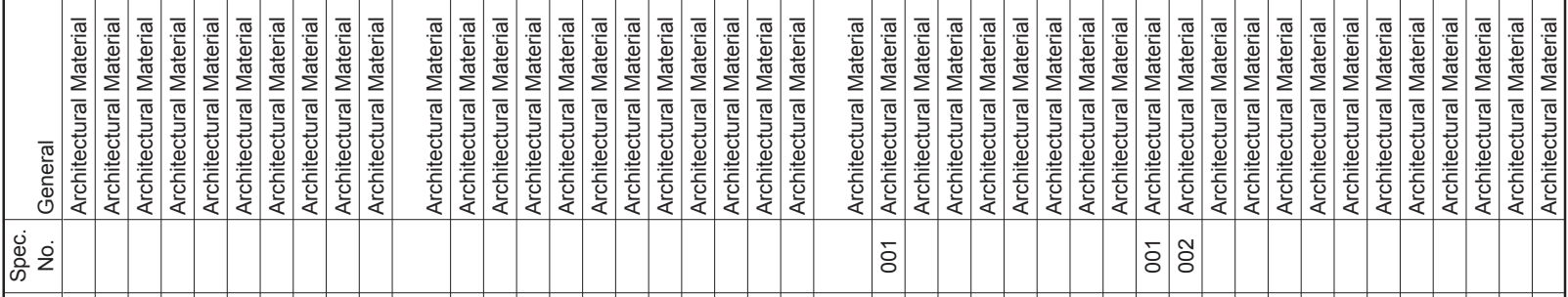

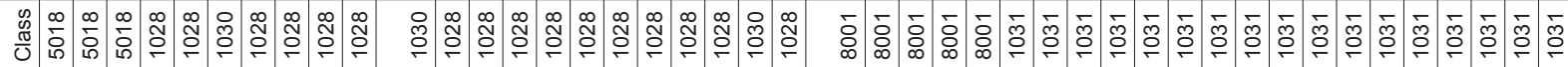

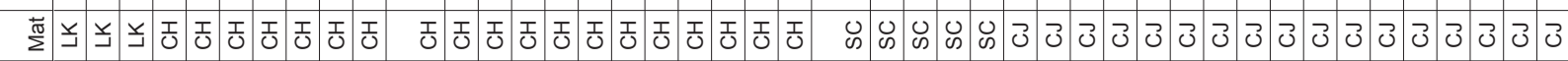

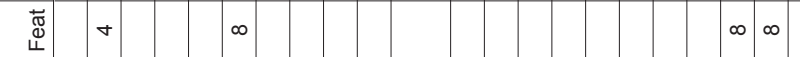

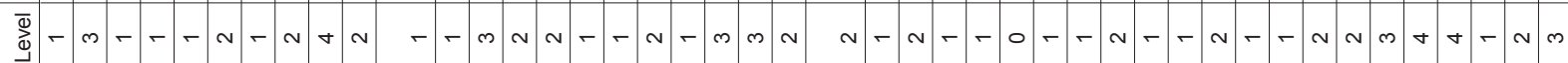

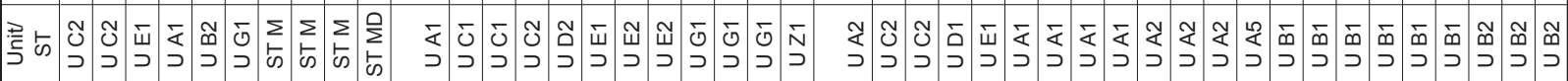

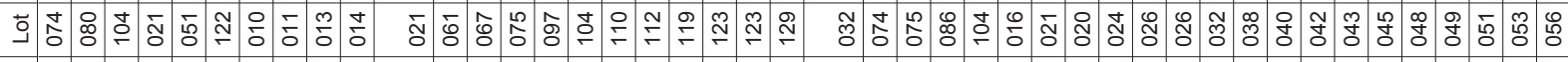

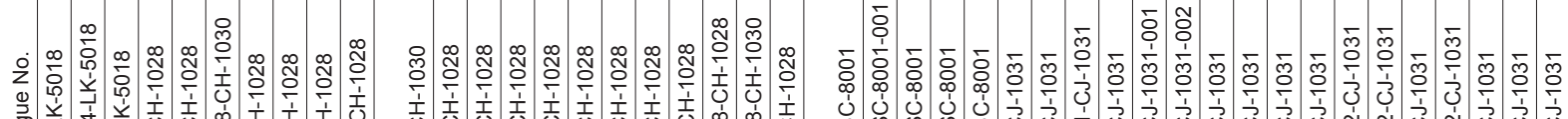

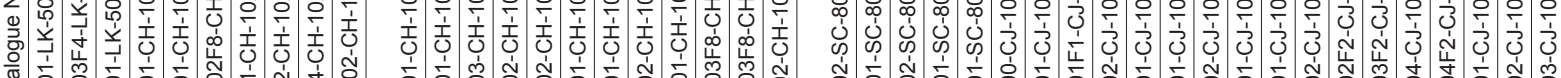

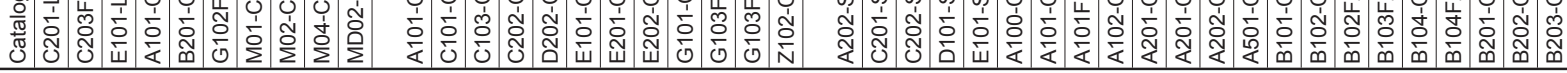




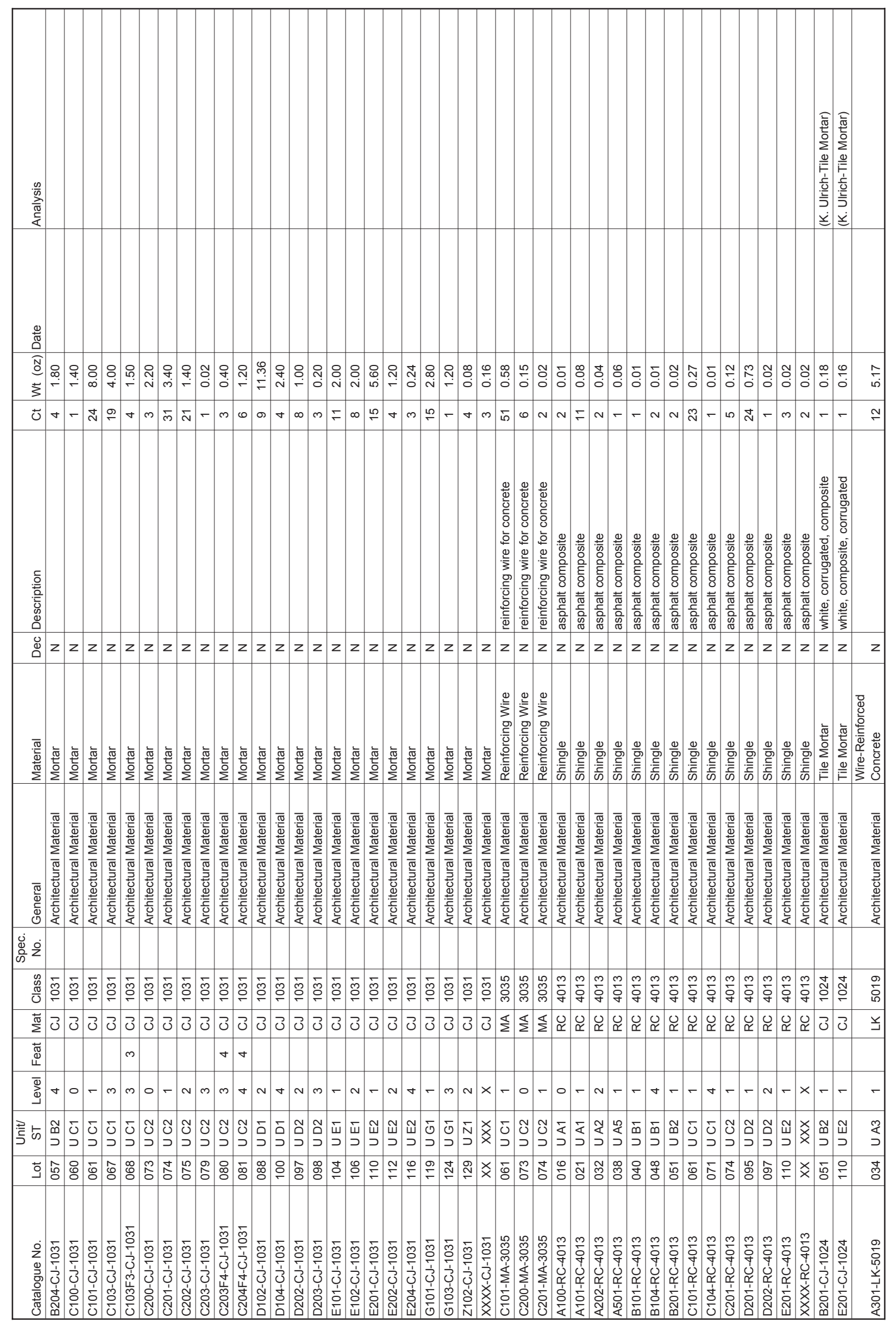









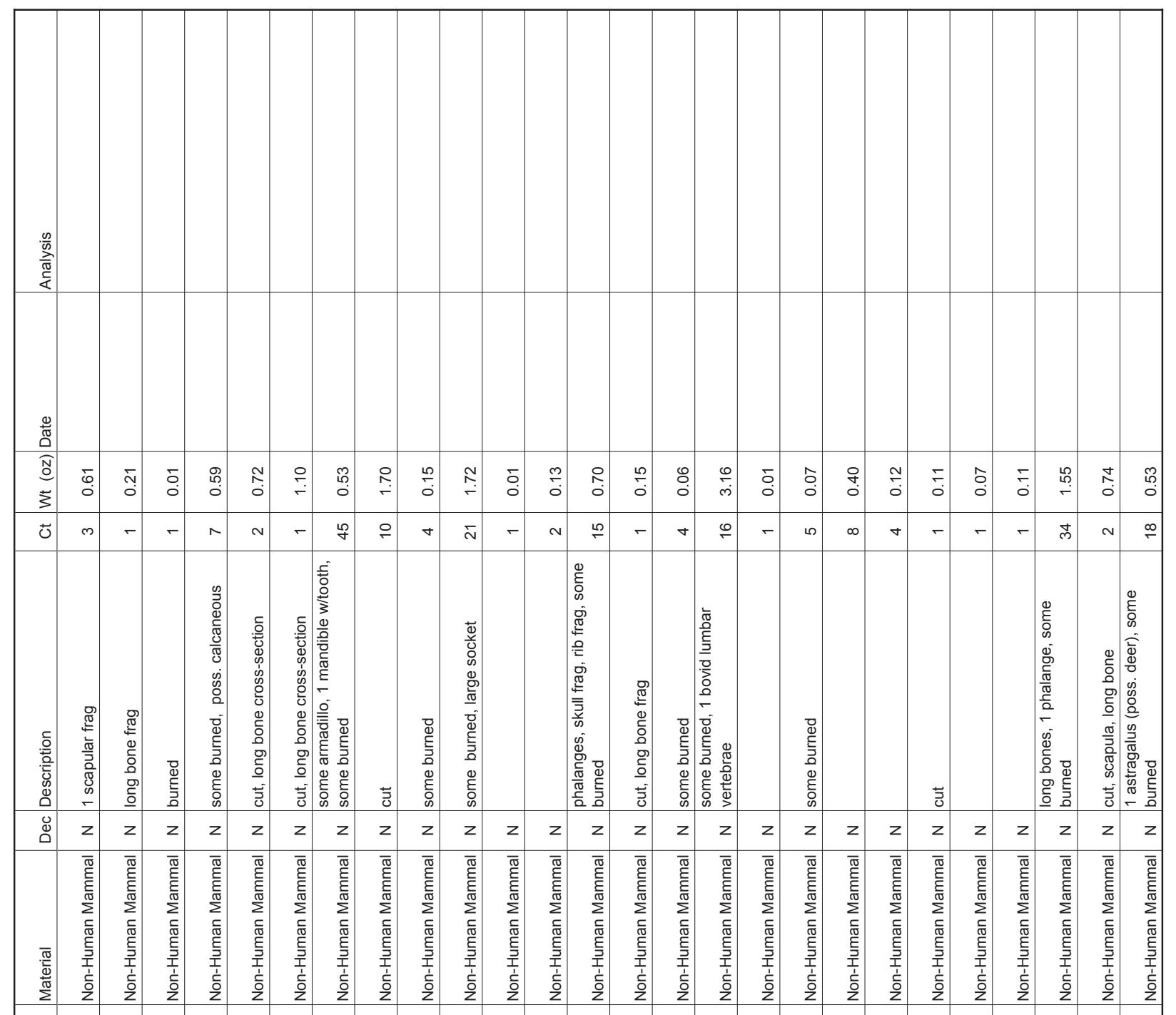

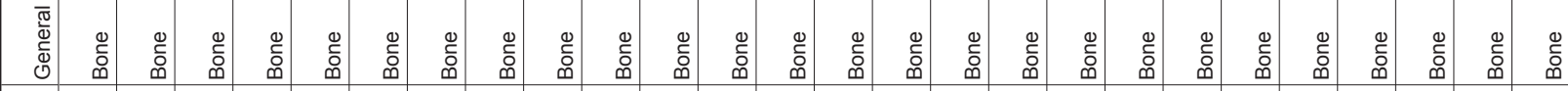
兽离定

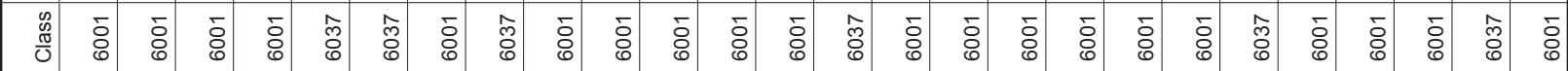

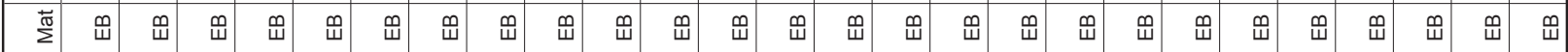

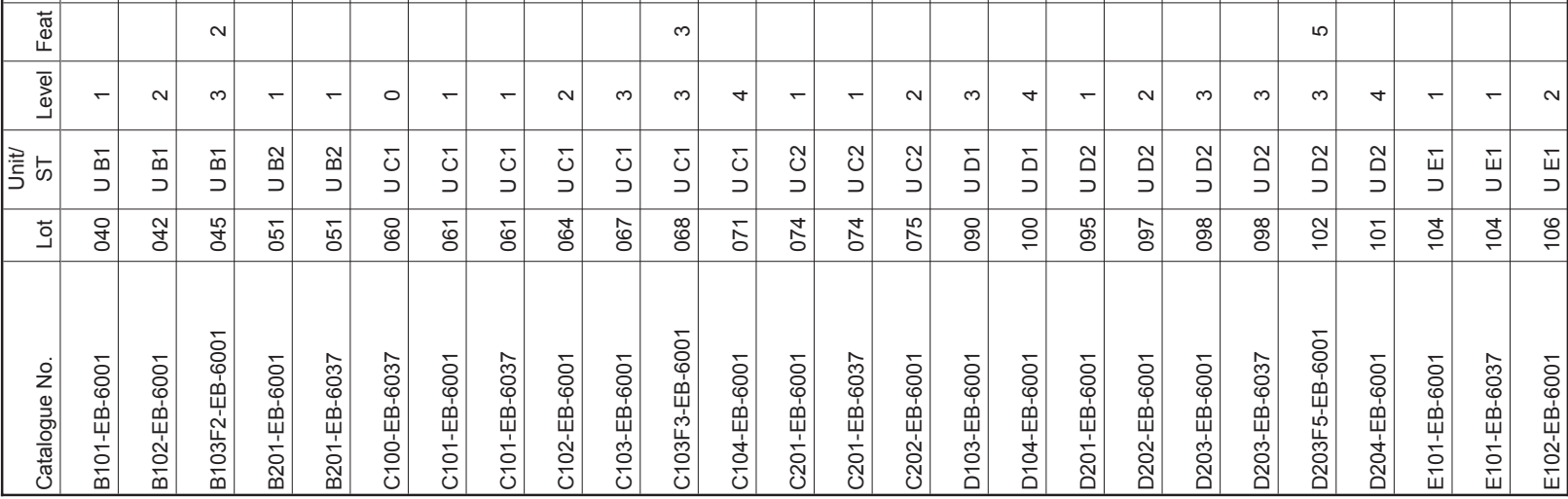




\begin{tabular}{|c|c|c|c|c|c|c|c|c|c|c|c|c|c|c|c|c|c|c|c|c|c|c|}
\hline $\begin{array}{l}\frac{\infty}{0} \\
\frac{0}{0} \\
\frac{\pi}{4} \\
\end{array}$ & & & & & & & & & & & & & & 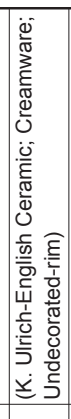 & 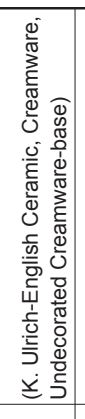 & 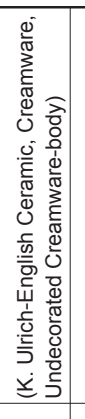 & 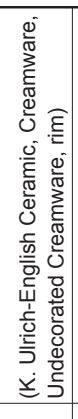 & 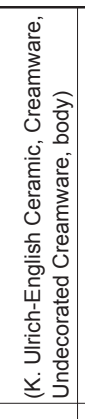 & 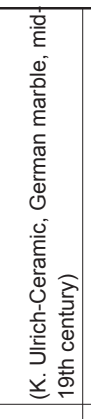 & 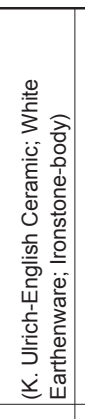 & 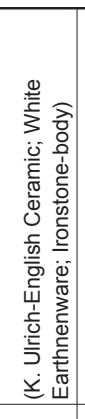 & 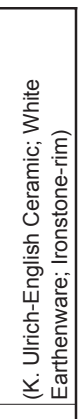 \\
\hline$\frac{\frac{d}{\pi}}{\mathrm{d}}$ & & & & & & & & & & & & & & 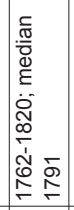 & 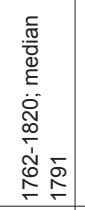 & 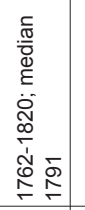 & 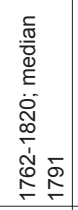 & 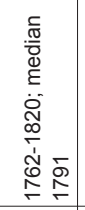 & 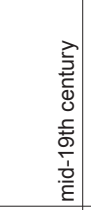 & 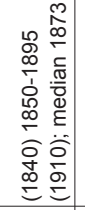 & 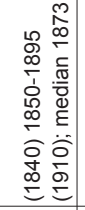 & 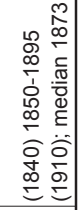 \\
\hline \begin{tabular}{l}
$\mid \widehat{\widehat{v}}$ \\
\multirow{3}{3}{}
\end{tabular} & $\begin{array}{l}m \\
0 \\
0\end{array}$ & 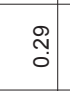 & స్ & $\begin{array}{l}\stackrel{8}{\circ} \\
\circ\end{array}$ & $\begin{array}{l}0 \\
\stackrel{0}{0} \\
0\end{array}$ & $\begin{array}{l}0 \\
0 \\
0\end{array}$ & $\begin{array}{l}0 \\
0 \\
0\end{array}$ & $\dot{s}$ & $\begin{array}{lll} \\
0\end{array}$ & 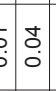 & 䇼 & $\stackrel{0}{:} \stackrel{\circ}{\circ}$ & $\stackrel{r}{\circ}$ & $\begin{array}{l}\stackrel{2}{0} \\
0\end{array}$ & 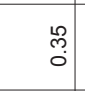 & $\stackrel{\frac{6}{\circ}}{\circ}$ & $\stackrel{\frac{J}{\circ}}{\dot{\circ}}$ & $\stackrel{0}{\circ}$ & సָ & $\stackrel{\stackrel{9}{\circ}}{\dot{0}}$ & 品 & 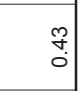 \\
\hline$\tilde{0}$ & - & $\infty$ & $m$ & $N$ & $N$ & - & -7 & - & $\sim-$ & $\sim \sim$ & - & $m$ & - & - & - & $m$ & - & - & - & - & - & - \\
\hline 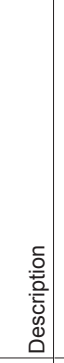 & 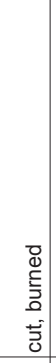 & 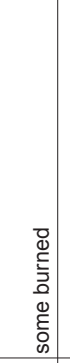 & & & $\mathrm{t}$ & & 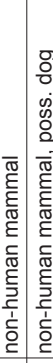 & 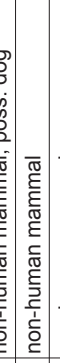 & 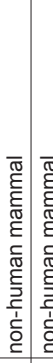 & 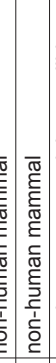 & 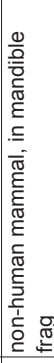 & 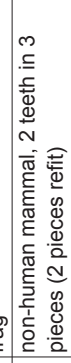 & 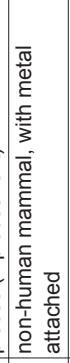 & 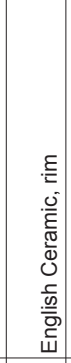 & 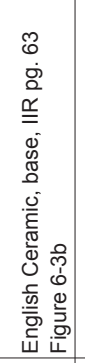 & 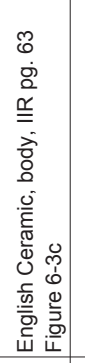 & 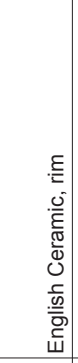 & 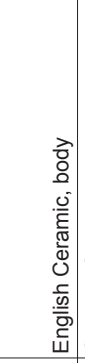 & 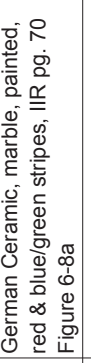 & 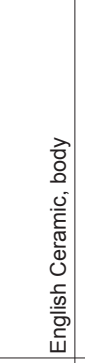 & 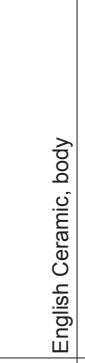 & 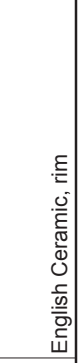 \\
\hline 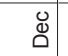 & $z$ & $z$ & $z$ & $z$ & $z$ & $z$ & $z z$ & $z$ & $z z$ & $z$ & $z$ & $z$ & $z$ & $z$ & $z$ & $z$ & $z$ & $z$ & $>$ & $z$ & $z$ & $z$ \\
\hline 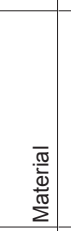 & 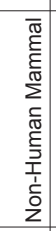 & 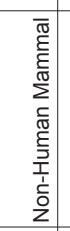 & 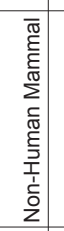 & 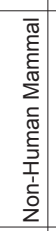 & 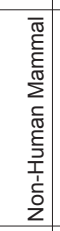 & 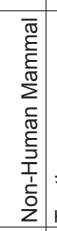 & 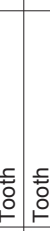 & 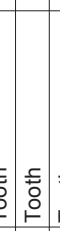 & 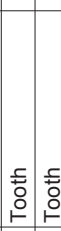 & 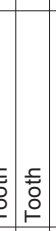 & 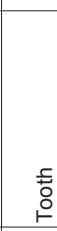 & : & 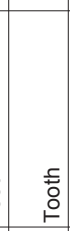 & 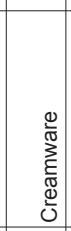 & 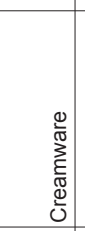 & 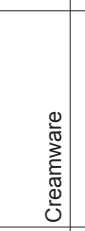 & 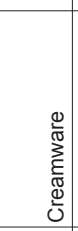 & 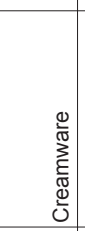 & $\begin{array}{l}\frac{\vec{J}}{0} \\
\frac{0}{0} \\
\bar{d}\end{array}$ & 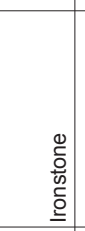 & 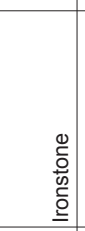 & 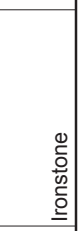 \\
\hline \begin{tabular}{c|}
$\overline{\frac{\pi}{\omega}}$ \\
$\overline{0}$ \\
$\overline{0}$ \\
0 \\
\end{tabular} & $\begin{array}{r}0 \\
\vdots \\
\vdots \\
0\end{array}$ & 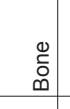 & 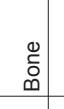 & $\begin{array}{r}0 \\
\stackrel{0}{\circ} \\
\end{array}$ & \begin{tabular}{l}
$₫$ \\
$\stackrel{0}{0}$ \\
\hdashline \\
\end{tabular} & 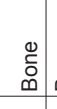 & 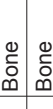 & 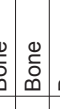 & 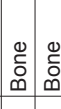 & 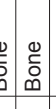 & 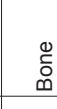 & $\begin{array}{c}0 \\
\vdots \\
\vdots\end{array}$ & 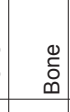 & 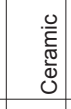 & 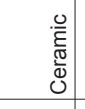 & 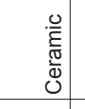 & 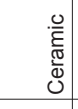 & 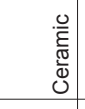 & 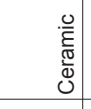 & 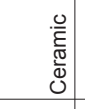 & 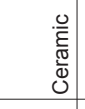 & 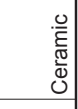 \\
\hline مu & & & & & & & & & & & & & & ஜ & $\stackrel{+}{\circ}$ & $\overline{8}$ & $\bar{\delta}$ & ธั & & & & $\stackrel{0}{\circ}$ \\
\hline $\begin{array}{c}\mathscr{w} \\
\frac{w}{0} \\
\end{array}$ & $\begin{array}{l}\hat{o} \\
0 \\
0\end{array}$ & $\bar{\delta}$ & $\bar{\vdots}$ & $\bar{\delta}$ & $\begin{array}{l}\hat{u} \\
0 \\
0\end{array}$ & $\bar{\delta}$ & \begin{tabular}{ll}
8 \\
\hdashline
\end{tabular} & $\begin{array}{l}0 \\
\vdots \\
0 \\
0 \\
0\end{array}$ & 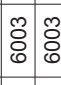 & \begin{tabular}{|c|c|}
0 \\
$\vdots$ \\
$\vdots$ \\
$\vdots$ \\
$\vdots$
\end{tabular} & \%ั & \% & $\begin{array}{l}0 \\
0 \\
0 \\
\end{array}$ & ڤ্র் & $\stackrel{\bar{\sigma}}{\circ}$ & চे & s. & ō & $\stackrel{\stackrel{\leftrightarrow}{0}}{\circ}$ & $\stackrel{\bar{\sigma}}{-}$ & ó & 훙 \\
\hline$\frac{\pi}{2}$ & 舀 & 邑 & 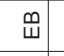 & 邑 & 吕 & 邑 & \begin{tabular}{l|l} 
\\
\end{tabular} & U & \begin{tabular}{|l|l|} 
\\
\end{tabular} & (口) & జ & 只 & 邑 & 0 & 0 & 0 & 0 & 0 & $\mathrm{I}$ & 0 & 0 & 0 \\
\hline 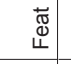 & & & & & & & & & & & & & & & & & & & & & & \\
\hline $\begin{array}{l}\bar{\sigma} \\
\bar{\Xi} \\
\end{array}$ & $N$ & - & $\sim$ & $\sigma$ & + & - & -- & - & m- & $-\sim$ & - & $m$ & $\nabla$ & $m$ & $N$ & $m$ & $\nabla$ & $\nabla$ & - & $\sim$ & - & - \\
\hline Pe & עי & $\begin{array}{l}\text { யี } \\
\supset\end{array}$ & ปั & $\stackrel{\text { జี }}{\supset}$ & $\begin{array}{l}\text { జี } \\
\supset\end{array}$ & $\begin{array}{l}\overline{0} \\
د\end{array}$ & \begin{tabular}{l|l}
$\stackrel{N}{\infty}$ & $\bar{U}$ \\
$\supset$
\end{tabular} & 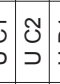 & \begin{tabular}{|l|l}
$\bar{u}$ \\
$د$
\end{tabular} & 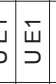 & జี & $\stackrel{\text { జี }}{\supset}$ & $\begin{array}{l}\text { யี } \\
د\end{array}$ & $\begin{array}{l}\mathrm{N} \\
\mathrm{J}\end{array}$ & 亏 & ড̀ & ป̃ & $\begin{array}{l}\text { Õ } \\
\text { Dे }\end{array}$ & $\begin{array}{l}\bar{x} \\
\end{array}$ & \begin{tabular}{l}
\multirow{4}{*}{} \\
\end{tabular} & $\begin{array}{l}\tilde{T} \\
\text { ปे }\end{array}$ & \begin{tabular}{l}
\multirow{2}{*}{} \\
$د$ \\
\end{tabular} \\
\hline 宁 & $\stackrel{\circ}{\circ}$ & $\stackrel{\circ}{\circ}$ & $\stackrel{\text { N }}{\mp}$ & $\stackrel{0}{\digamma}$ & $\stackrel{\oplus}{\rightleftharpoons}$ & $\stackrel{?}{\rightleftharpoons}$ & $\overline{8} \overline{8}$ & 5 & 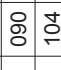 & $\stackrel{0}{\circ}$ & 욷 & $\stackrel{F}{\rightleftharpoons}$ & $\stackrel{0}{\rightleftharpoons}$ & 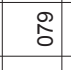 & $\stackrel{\infty}{\circ}$ & 8 & $\stackrel{\square}{\circ}$ & 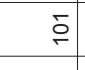 & $\bar{\delta}$ & ป্ర & $\stackrel{0}{0}$ & 范 \\
\hline \begin{tabular}{c|c}
0 \\
2 \\
0 \\
$\overline{0}$ \\
$\frac{0}{0}$ \\
$\frac{\pi}{0}$ \\
0 \\
\end{tabular} & 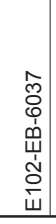 & 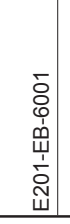 & 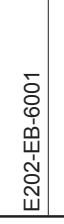 & $\begin{array}{l}\bar{\delta} \\
0 \\
\dot{\omega} \\
\tilde{u} \\
\dot{u} \\
\tilde{w} \\
\end{array}$ & 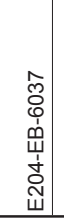 & $\begin{array}{l}\overline{0} \\
0 \\
0 \\
w \\
\vdots \\
\vdots \\
0 \\
0\end{array}$ & 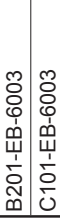 & 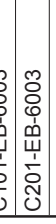 & 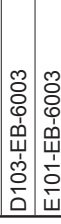 & 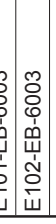 & 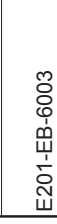 & 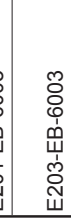 & 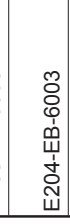 & 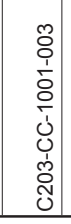 & 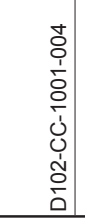 & 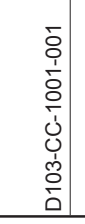 & $\begin{array}{l}\bar{o} \\
1 \\
\bar{o} \\
\bar{c} \\
\dot{j} \\
0 \\
\dot{1} \\
0\end{array}$ & 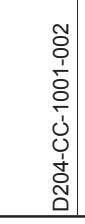 & $\begin{array}{l}\mathbf{t} \\
\frac{0}{1} \\
\frac{1}{1} \\
\underline{1} \\
\end{array}$ & 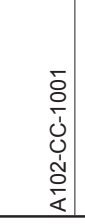 & 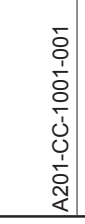 & $\begin{array}{l}0 \\
0 \\
\vdots \\
0 \\
\dot{j} \\
0 \\
\vdots \\
\vdots\end{array}$ \\
\hline
\end{tabular}




\begin{tabular}{|c|c|c|c|c|c|c|c|c|c|c|c|c|c|c|c|c|c|}
\hline $\begin{array}{l}\frac{0}{3} \\
\frac{0}{00} \\
\frac{10}{4}\end{array}$ & 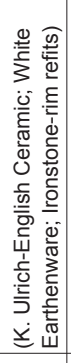 & 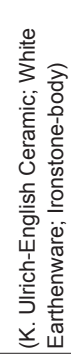 & 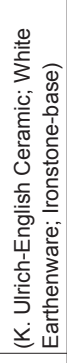 & 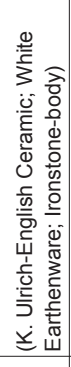 & 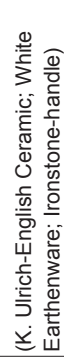 & 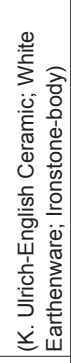 & 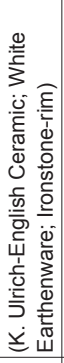 & 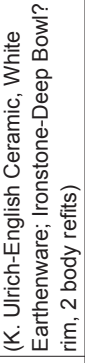 & 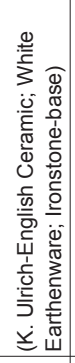 & 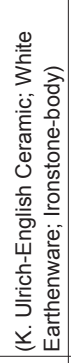 & 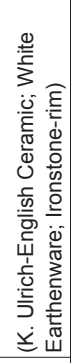 & 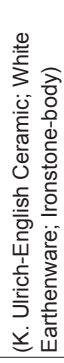 & 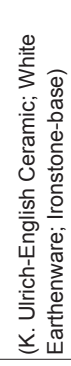 & 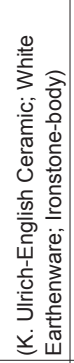 & 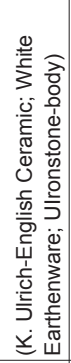 & 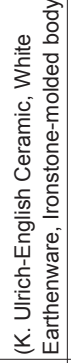 & 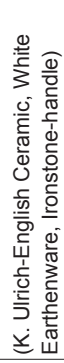 \\
\hline ֻू & 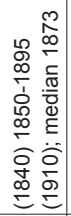 & 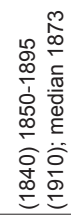 & 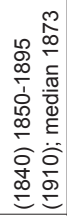 & 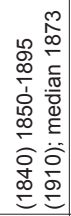 & 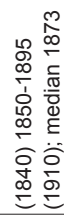 & 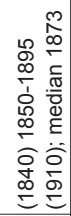 & 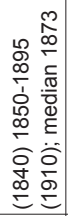 & 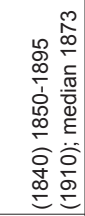 & 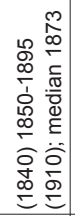 & 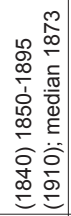 & 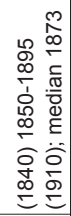 & 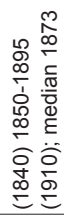 & 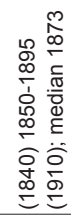 & 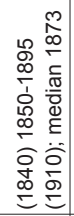 & 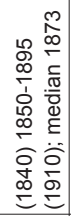 & 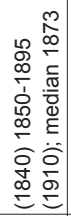 & 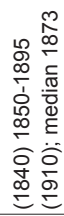 \\
\hline $\begin{array}{l}\widehat{N} \\
\hat{3}\end{array}$ & $\begin{array}{l}\text { t } \\
0\end{array}$ & $\stackrel{\text { fo }}{\circ}$ & 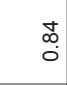 & J & ্ָণ & $\stackrel{\circ}{\circ}$ & 范 & $\underset{\mathbb{N}}{\mathbb{N}}$ & $\begin{array}{l}\hat{f} \\
0\end{array}$ & $\stackrel{N}{0}$ & ז.s & $\stackrel{ }{\circ}$ & 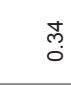 & 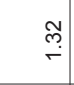 & 8 & $\begin{array}{l}0 \\
0 \\
0\end{array}$ & :̊̊. \\
\hline$\tilde{0}$ & $N$ & $m$ & $N$ & - & - & $\sigma$ & - & 0 & - & - & $m$ & - & - & N & - & - & - \\
\hline 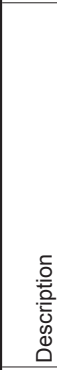 & 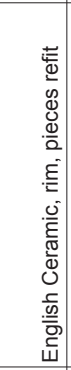 & 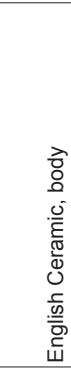 & 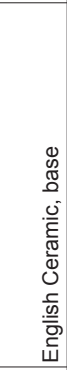 & 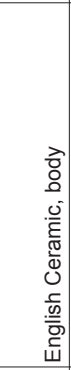 & 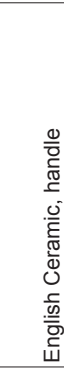 & 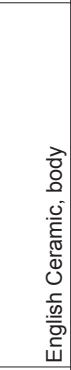 & 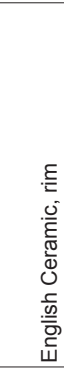 & 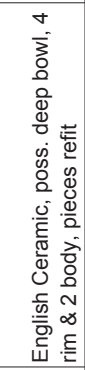 & 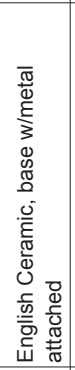 & 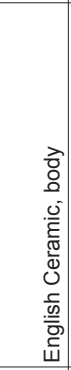 & 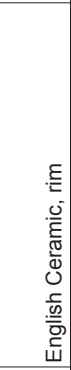 & 항 & 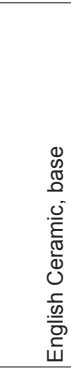 & 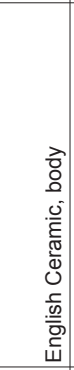 & 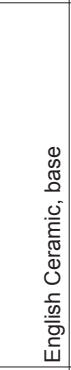 & 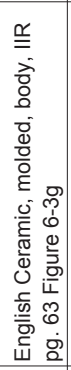 & 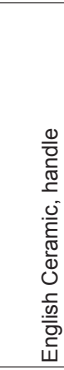 \\
\hline ष्ष & $z$ & $z$ & $z$ & $\mathrm{z}$ & $z$ & $\mathrm{z}$ & $z$ & $z$ & $z$ & $z$ & $z$ & $z$ & $z$ & $\mathrm{z}$ & $z$ & $>$ & $z$ \\
\hline 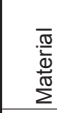 & 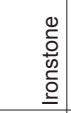 & 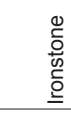 & 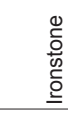 & $\begin{array}{l}0 \\
\text { D } \\
\underline{0} \\
\underline{\underline{0}} \\
\end{array}$ & 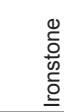 & 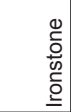 & 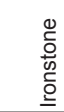 & 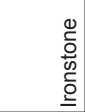 & 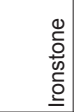 & 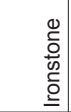 & $\begin{array}{l}\stackrel{0}{0} \\
\text { o } \\
\underline{\underline{0}}\end{array}$ & $\begin{array}{l}\stackrel{0}{0} \\
\text { to } \\
\underline{\underline{0}}\end{array}$ & 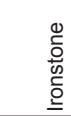 & 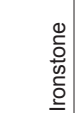 & 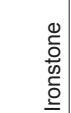 & 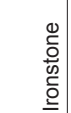 & $\overbrace{0}^{\infty}$ \\
\hline $\begin{array}{l}\bar{\sigma} \\
\overline{0} \\
\overline{0} \\
0 \\
\end{array}$ & 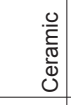 & 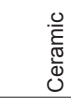 & 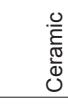 & 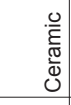 & 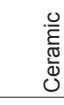 & $\begin{array}{l}.0 \\
\bar{E} \\
\frac{\pi}{0} \\
0 \\
\end{array}$ & 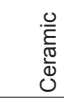 & 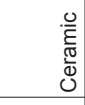 & 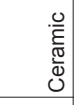 & $\begin{array}{l}\frac{\bar{w}}{0} \\
0 \\
\end{array}$ & $\begin{array}{l}.0 \\
\bar{E} \\
\frac{\pi}{\tilde{L}} \\
0 \\
\end{array}$ & $\begin{array}{l}\frac{\pi}{\pi} \\
0 \\
0\end{array}$ & 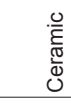 & $\begin{array}{l}.0 \\
\bar{E} \\
\frac{\pi}{\tilde{L}} \\
0 \\
\end{array}$ & $\begin{array}{l}\frac{c}{\pi} \\
\frac{\pi}{\tilde{U}} \\
\mathcal{U}\end{array}$ & 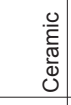 & 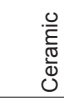 \\
\hline 崩 & $\stackrel{ \pm}{\circ}$ & $\stackrel{\circ}{8}$ & 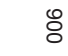 & $\overline{8}$ & ธิ & $\overline{8}$ & ธิ & $\overline{8}$ & $\overline{8}$ & ธิ & $\bar{\delta}$ & ธิ & \% & ธี & ○̊ & $\stackrel{\circ}{\circ}$ & $\overline{8}$ \\
\hline $\begin{array}{l}\mathscr{\mathscr { D }} \\
\frac{\mathbb{\pi}}{\mathrm{O}}\end{array}$ & $\bar{o}$ & $\stackrel{\bar{\sigma}}{\circ}$ & $\stackrel{\bar{\sigma}}{\circ}$ & $\bar{o}$ & $\stackrel{\bar{\sigma}}{\circ}$ & $\bar{\circ}$ & $\bar{\circ}$ & $\stackrel{\bar{\sigma}}{\circ}$ & $\stackrel{\circ}{\circ}$ & $\bar{o}$ & $\bar{\circ}$ & $\bar{\circ}$ & $\stackrel{\circ}{\circ}$ & $\stackrel{\circ}{\circ}$ & $\stackrel{\circ}{\circ}$ & $\begin{array}{l}0 \\
\stackrel{0}{o}\end{array}$ & $\stackrel{\circ}{\circ}$ \\
\hline$\sum_{2}^{\bar{\pi}}$ & U & O & O & U & O & U & O & O & U & U & U & O & U & U & U & O & O \\
\hline $\begin{array}{l}\overline{\widetilde{\varpi}} \\
\text { L }\end{array}$ & & & & & & & & & & & & & & & & & \\
\hline$\stackrel{\bar{\rho}}{\stackrel{\omega}{\omega}}$ & - & - & - & - & - & - & - & $N$ & $m$ & $m$ & - & - & - & $\sim$ & $N$ & $N$ & N \\
\hline 急占 & 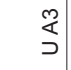 & $\stackrel{m}{5}$ & $\stackrel{m}{5}$ & $\begin{array}{l}\bar{m} \\
\supset\end{array}$ & $\stackrel{\aleph}{\nu}$ & $\begin{array}{l}\bar{U} \\
\partial\end{array}$ & $\begin{array}{l}\bar{J} \\
\end{array}$ & $\begin{array}{l}\bar{J} \\
\end{array}$ & $\begin{array}{l}\bar{U} \\
J\end{array}$ & $\begin{array}{l}\bar{\jmath} \\
\partial\end{array}$ & $\begin{array}{l}\tilde{U} \\
\text { J }\end{array}$ & $\widetilde{\mathcal{~}}$ & $\begin{array}{l}\tilde{N} \\
\text { J }\end{array}$ & $\begin{array}{l}\tilde{J} \\
\text { J }\end{array}$ & $\begin{array}{l}\tilde{U} \\
\mathcal{J}\end{array}$ & $\begin{array}{l}\tilde{U} \\
\text { J }\end{array}$ & $\bar{a}$ \\
\hline $\bar{\jmath}$ & 范 & 范 & 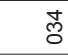 & q & 항 & $\overline{8}$ & $\overline{8}$ & $\stackrel{\square}{\circ}$ & $\hat{8}$ & $\hat{\ddot{\theta}}$ & 壳 & 吉 & 吉 & $\stackrel{2}{\circ}$ & $\begin{array}{l}\stackrel{2}{\circ} \\
\end{array}$ & $\begin{array}{l}0 \\
0\end{array}$ & $\begin{array}{l}\infty \\
\stackrel{\infty}{\infty}\end{array}$ \\
\hline$z$ & 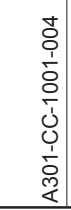 & 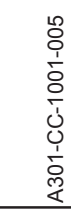 & 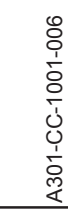 & 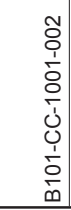 & 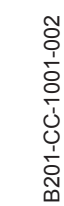 & $\begin{array}{l}\bar{\vdots} \\
\overline{1} \\
\dot{0} \\
\overline{0} \\
0 \\
\dot{1} \\
\dot{0} \\
\end{array}$ & 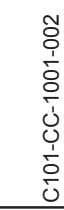 & 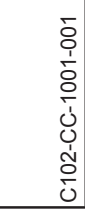 & 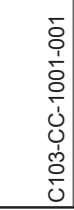 & 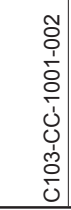 & 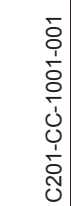 & 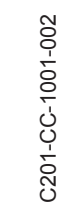 & 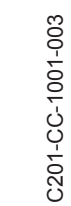 & 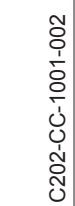 & 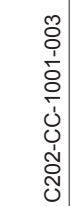 & 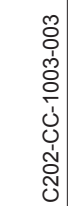 & $\begin{array}{l}\bar{o} \\
\overline{1} \\
\overline{0} \\
\overline{0} \\
0\end{array}$ \\
\hline
\end{tabular}




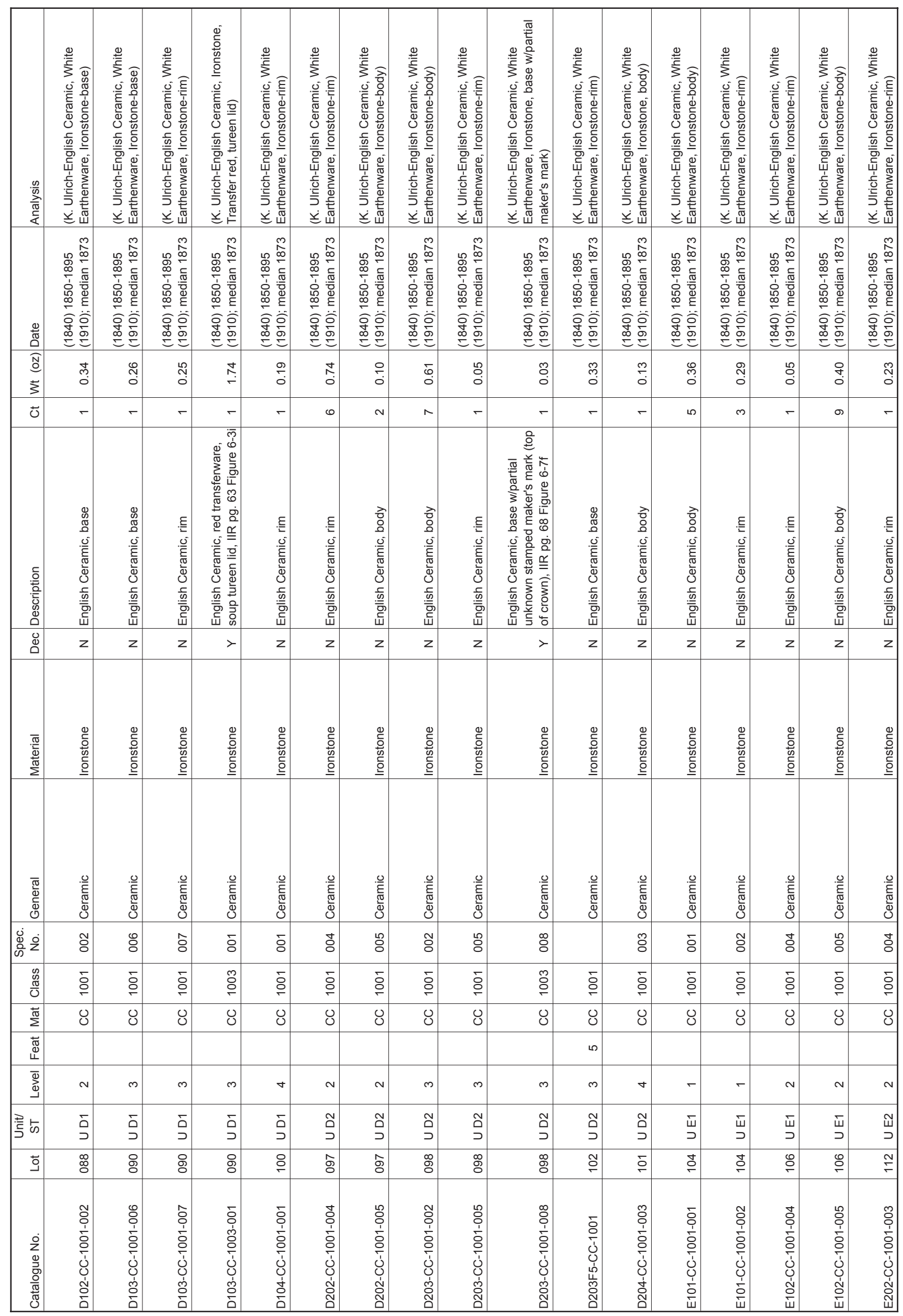




\begin{tabular}{|c|c|c|c|c|c|c|c|c|c|c|c|c|c|c|c|c|c|c|c|c|c|c|}
\hline & 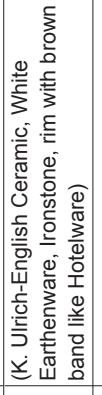 & 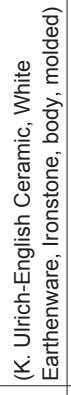 & 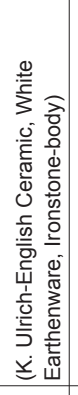 & 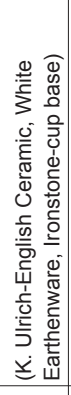 & & 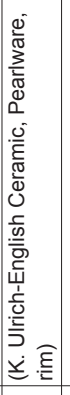 & & 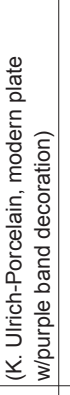 & 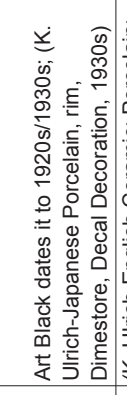 & 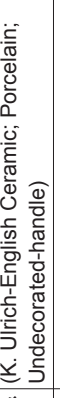 & & 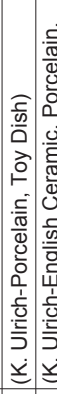 & 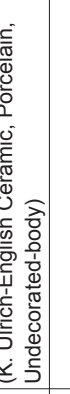 & 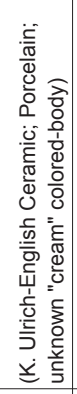 & & 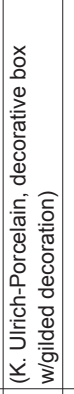 & & 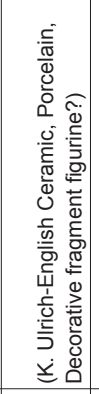 & & & 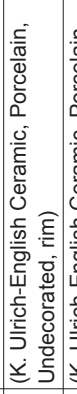 & 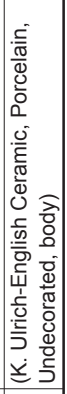 \\
\hline$\frac{⿱}{\frac{0}{\sigma}}$ & 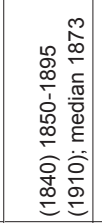 & 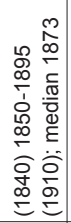 & 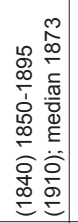 & 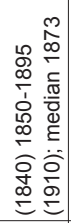 & 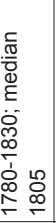 & 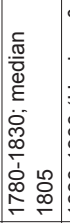 & 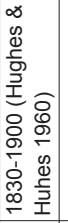 & & 灾 & 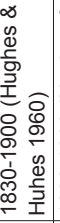 & 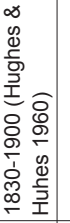 & & 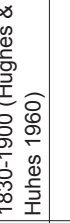 & 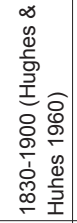 & 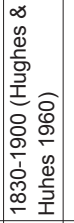 & & 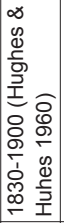 & 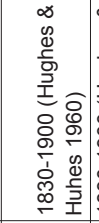 & 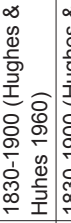 & 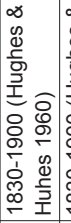 & 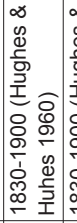 & 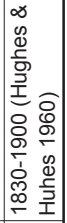 \\
\hline $\begin{array}{l}\widehat{N} \\
0 \\
\overrightarrow{3}\end{array}$ & $\begin{array}{l}\hat{b} \\
0 \\
0\end{array}$ & $\stackrel{5}{\circ}$ & $\stackrel{8}{\circ}$ & 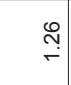 & $\begin{array}{l}0 \\
\\
\end{array}$ & $\stackrel{\infty}{0}$ & 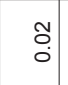 & $\begin{array}{l}9 \\
0 \\
0\end{array}$ & $\stackrel{\infty}{0}$ & $\begin{array}{l}\text { ㅇ. } \\
0 \\
\end{array}$ & $\begin{array}{l}m \\
0 \\
0 \\
0\end{array}$ & \begin{tabular}{|l|} 
\\
0 \\
0 \\
\end{tabular} & $\begin{array}{l}\text { to } \\
0\end{array}$ & ז. & $\begin{array}{l}\overline{0} \\
0 \\
0\end{array}$ & $\begin{array}{l}\hat{0} \\
0 \\
0\end{array}$ & $\begin{array}{l}\overline{0} \\
\vdots \\
\end{array}$ & $\begin{array}{l}\text { t. } \\
\text { o. }\end{array}$ & $\begin{array}{l}\text { L } \\
\stackrel{0}{0} \\
0\end{array}$ & $\begin{array}{l}m \\
0 \\
0\end{array}$ & & ָِ \\
\hline$\tilde{0}$ & - & - & - & - & - & - & - & - & - & $r$ & - & - & - & $m$ & - & - & -7 & - & 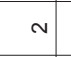 & - & m & ๑ \\
\hline 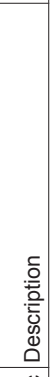 & 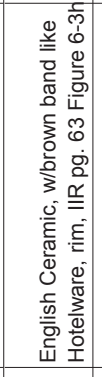 & 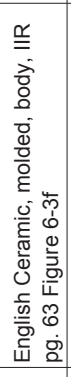 & 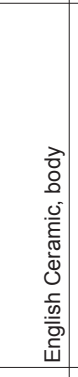 & 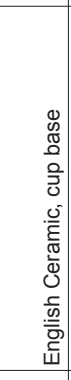 & 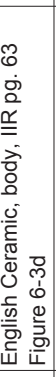 & 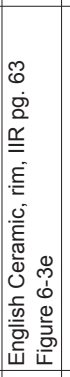 & 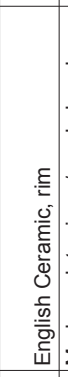 & 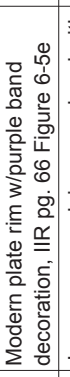 & 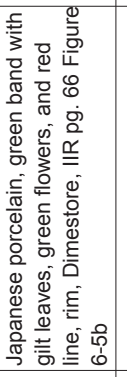 & 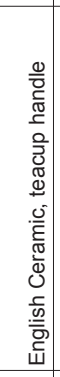 & 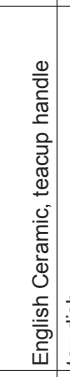 & $\mid$ & 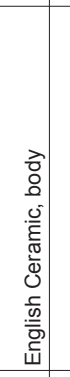 & 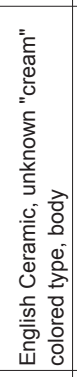 & 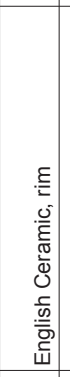 & 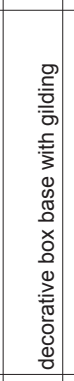 & 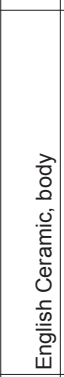 & 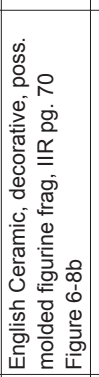 & 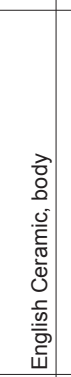 & 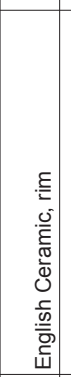 & 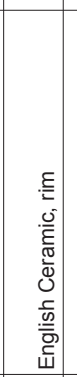 & 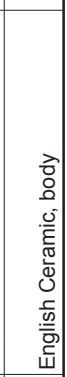 \\
\hline$\stackrel{0}{0}$ & $>$ & $>$ & $z$ & $z$ & $z$ & $z$ & $z$ & $>$ & $>$ & $z$ & $z$ & $z$ & $z$ & $z$ & $z$ & $>$ & 8 & $>$ & $\mathrm{z}$ & $z$ & $\mathrm{z}$ & $z$ \\
\hline 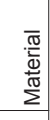 & 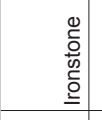 & 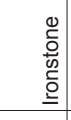 & $\begin{array}{l}\stackrel{0}{0} \\
\underline{5} \\
\underline{0} \\
\underline{\underline{\underline{0}}} \\
\end{array}$ & $\begin{array}{l}\stackrel{0}{0} \\
\underline{0} \\
\underline{0} \\
\underline{\underline{0}} \\
\end{array}$ & 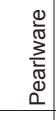 & 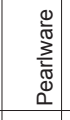 & 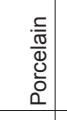 & 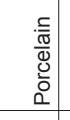 & 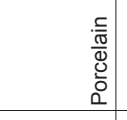 & 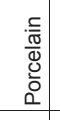 & 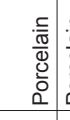 & 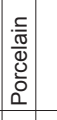 & 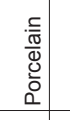 & 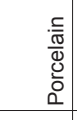 & 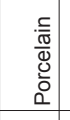 & 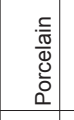 & 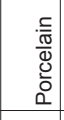 & 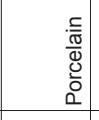 & 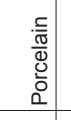 & 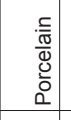 & 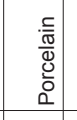 & ¿̄ \\
\hline $\begin{array}{l}\overline{\widetilde{\sigma}} \\
\bar{\Phi} \\
\overline{\mathbb{E}} \\
0 \\
\end{array}$ & 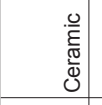 & 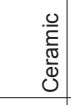 & 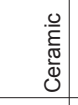 & 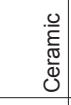 & 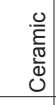 & 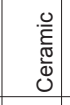 & 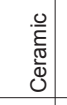 & 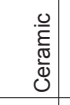 & 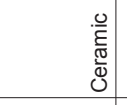 & 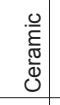 & 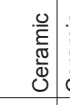 & 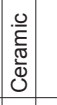 & 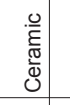 & 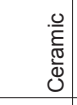 & 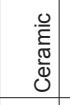 & 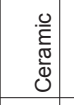 & 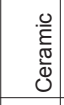 & 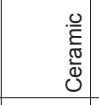 & 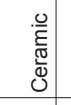 & 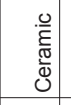 & $\begin{array}{l}\frac{\pi}{\pi} \\
\frac{\pi}{0} \\
\mathcal{U}\end{array}$ & 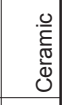 \\
\hline$\dot{z}$ & $\bar{\Xi}$ & ธิ & ธิ & \&̊ & $\bar{s}$ & : & ธิ & $\overline{8}$ & ธี & ८ั & & $\bar{\delta}$ & ธั & ठ̊ & & & & & $\overline{8}$ & ธี & $\overline{8}$ & ธิ \\
\hline $\begin{array}{l}q \\
w \\
\frac{\pi}{U}\end{array}$ & $\stackrel{\text { \% }}{\circ}$ & $\begin{array}{l}0 \\
\stackrel{0}{0}\end{array}$ & চे & $\bar{\delta}$ & $\bar{\delta}$ & $\bar{o}$ & $\bar{\circ}$ & $?$ & m & $\begin{array}{l}\text { \% } \\
\stackrel{\circ}{\circ}\end{array}$ & $\stackrel{\square}{\circ}$ & $\bar{\delta}$ & $\bar{\circ}$ & $\bar{\delta}$ & $\bar{\sigma}$ & $\stackrel{\text { \% }}{\circ}$ & চֵ & 足 & $\overline{0}$ & $\bar{\sigma}$ & $\bar{\delta}$ & 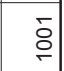 \\
\hline$\frac{\pi}{\pi}$ & U & 0 & 0 & 0 & 0 & 0 & $\delta$ & $\delta$ & $\delta$ & $\widehat{J}$ & 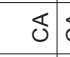 & J & $\widehat{\delta}$ & $\widetilde{J}$ & $\mathbb{0}$ & $\widehat{\delta}$ & త & $\delta$ & 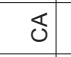 & 0 & $\delta$ & $\widehat{\mho}$ \\
\hline $\begin{array}{l}\vec{\Phi} \\
\stackrel{\Phi}{W} \\
\end{array}$ & & & & & & & & & & & & & & & & & 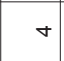 & $\nabla$ & & & & \\
\hline$\overline{\mathrm{D}}$ & 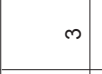 & $\infty$ & $\nabla$ & $\nabla$ & $m$ & $m$ & 0 & $r$ & - & - & - & N & $\sim$ & $N$ & $m$ & $m$ & $m$ & $m$ & $m$ & $m$ & $N$ & $\sim$ \\
\hline 勿 & Щี & ખّ & Щี & ّㅣㄹ & $\supset$ & ป̃ & $\overline{\mathrm{s}}$ & $J$ & J & 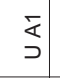 & $\stackrel{\tilde{J}}{\supset}$ & $\begin{array}{l}\mathcal{N} \\
\text { כે }\end{array}$ & $\begin{array}{l}\text { ঠे } \\
\text { J }\end{array}$ & $\begin{array}{l}\widetilde{N} \\
\text { Ј }\end{array}$ & $\begin{array}{l}\tilde{N} \\
\text { J }\end{array}$ & $\begin{array}{l}\text { ঠे } \\
\text { J }\end{array}$ & 8 & $\begin{array}{l}\tilde{U} \\
\mathrm{~J}\end{array}$ & $\bar{\Delta}$ & 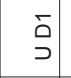 & ปั & $\tilde{\Xi}$ \\
\hline ఏ & $\stackrel{\nabla}{\rightleftharpoons}$ & $\stackrel{ \pm}{\rightleftharpoons}$ & $\stackrel{0}{\check{0}}$ & $\stackrel{0}{r}$ & $\infty$ & $\begin{array}{l}\infty \\
\stackrel{0}{\circ}\end{array}$ & $\stackrel{0}{0}$ & $\bar{\delta}$ & $\bar{\delta}$ & $\bar{\delta}$ & $\stackrel{0}{0}$ & 茂 & $\stackrel{2}{0}$ & 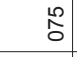 & $\stackrel{a}{o}$ & $\stackrel{̊}{\circ}$ & $\infty$ & $\stackrel{\circ}{\circ}$ & ঃ & . & à & 응 \\
\hline$z$ & 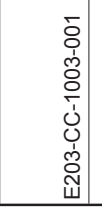 & 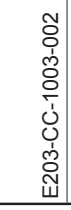 & 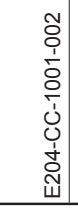 & 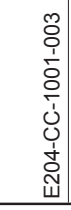 & 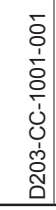 & 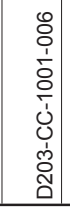 & 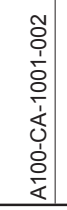 & 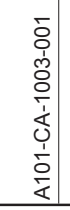 & 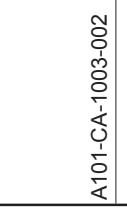 & 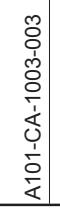 & 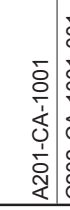 & 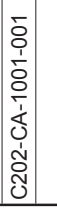 & 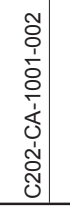 & 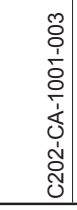 & 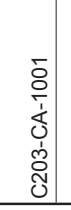 & 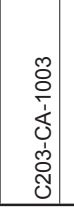 & 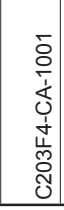 & 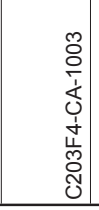 & $\begin{array}{l}\bar{c} \\
\vdots \\
0 \\
0 \\
\frac{1}{0} \\
0 \\
0 \\
0 \\
\vdots \\
\vdots\end{array}$ & $\mid \begin{array}{l}0 \\
0 \\
0 \\
0 \\
0 \\
\frac{1}{0} \\
0 \\
0 \\
0 \\
0 \\
0\end{array}$ & 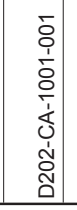 & 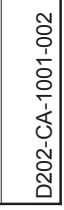 \\
\hline
\end{tabular}




\begin{tabular}{|c|c|c|c|c|c|c|c|c|c|c|c|c|c|c|c|c|c|c|c|c|c|c|c|c|}
\hline $\begin{array}{l}\frac{n}{00} \\
\frac{2}{\pi} \\
\frac{0}{4}\end{array}$ & 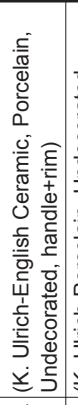 & 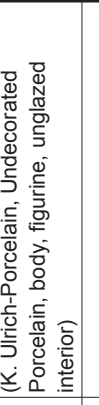 & & & 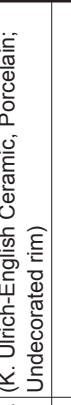 & & & & & 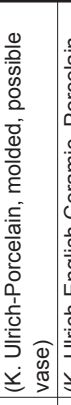 & 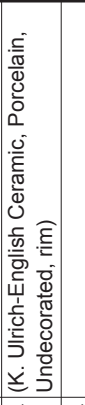 & & & & 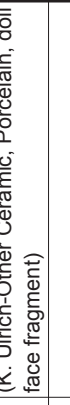 & & 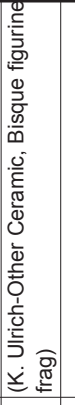 & 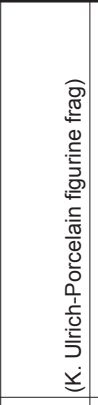 & 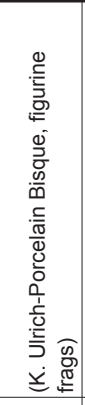 & 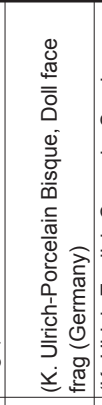 & 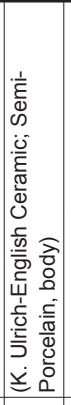 & 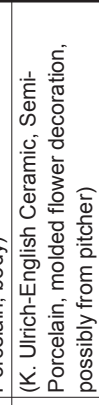 & 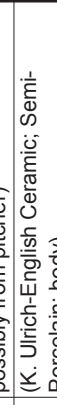 & 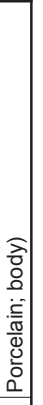 \\
\hline $\begin{array}{l}\frac{0}{\pi} \\
\frac{\pi}{2}\end{array}$ & 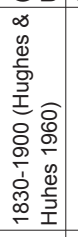 & & 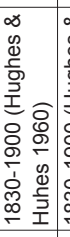 & 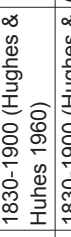 & 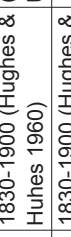 & 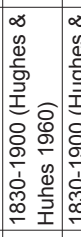 & 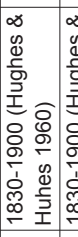 & 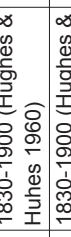 & 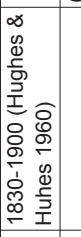 & & 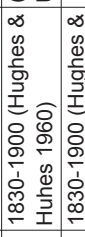 & 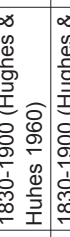 & 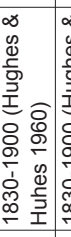 & 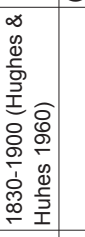 & & & & & & & 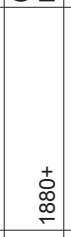 & 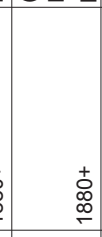 & & 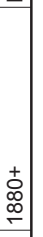 \\
\hline $\begin{array}{l}\widehat{N} \\
0 \\
3\end{array}$ & $\underset{0}{\sigma}$ & $\begin{array}{l}\text { t. } \\
\text { : }\end{array}$ & $\underset{0}{\circ}$ & $\begin{array}{l}\hat{0} \\
0 \\
0\end{array}$ & $\stackrel{m}{\circ}$ & \begin{tabular}{|l|} 
\\
\\
0 \\
\end{tabular} & $\stackrel{m}{\circ}$ & $\begin{array}{l}\hat{0} \\
0 \\
0\end{array}$ & $\begin{array}{l}0 \\
\vdots \\
0 \\
0\end{array}$ & $\begin{array}{l} \\
\\
0\end{array}$ & $\begin{array}{l}0 \\
0 \\
0\end{array}$ & $\begin{array}{l} \\
\tilde{O} \\
0\end{array}$ & $\begin{array}{l} \\
\\
0\end{array}$ & $\begin{array}{l}\stackrel{2}{\circ} \\
\dot{0}\end{array}$ & $\begin{array}{l} \\
\\
0 \\
\end{array}$ & $\stackrel{m}{\circ}$ & $\begin{array}{l}\delta \\
\dot{0}\end{array}$ & $\begin{array}{l}0 \\
\stackrel{0}{0} \\
0\end{array}$ & స్. & $\stackrel{\circ}{\circ}$ & $\begin{array}{l}0 \\
\stackrel{0}{0} \\
0\end{array}$ & $\begin{array}{l}0 \\
\stackrel{\infty}{0} \\
0\end{array}$ & & ֻे \\
\hline$\tilde{0}$ & - & - & $\nabla$ & - & $N$ & $r$ & $N$ & - & - & - & - & - & - & - & - & - & - & - & $\nabla$ & m & - & - & & - \\
\hline $\begin{array}{l}\text { 흘 } \\
\text { 흠 } \\
\overline{\mathrm{d}} \\
\mathrm{d} \\
\mathrm{a}\end{array}$ & 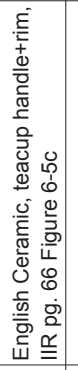 & 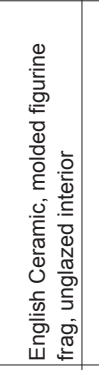 & 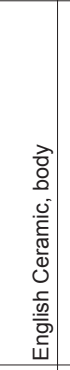 & 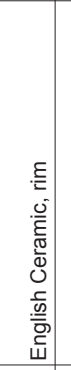 & 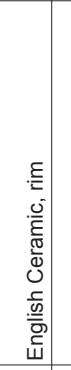 & 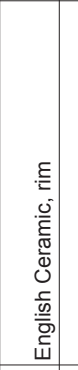 & 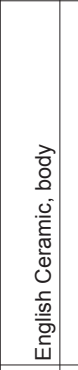 & 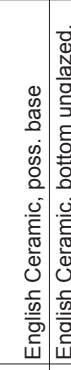 & 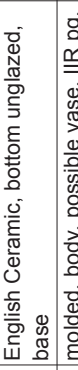 & 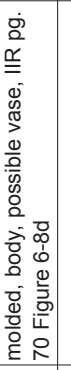 & 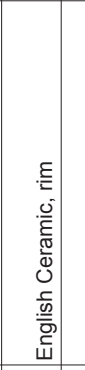 & 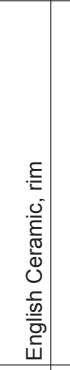 & 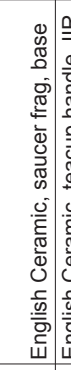 & 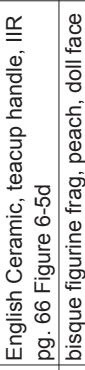 & 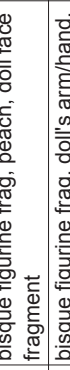 & 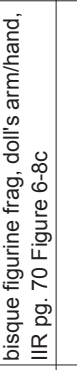 & 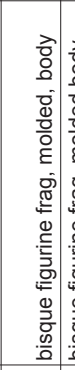 & 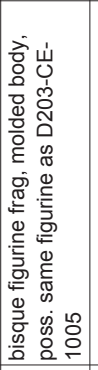 & 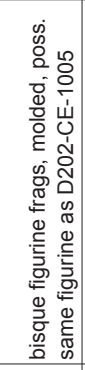 & 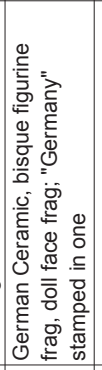 & 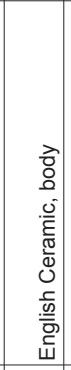 & 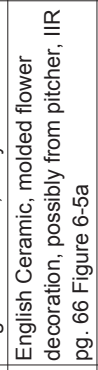 & 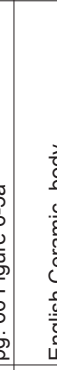 & 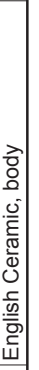 \\
\hline $\begin{array}{l}\mathscr{\Xi} \\
\end{array}$ & $z$ & $>$ & $z$ & z & $z$ & z & $z$ & $z$ & $z$ & $>$ & $z$ & z & z & $z$ & $>$ & $>$ & $>$ & $>$ & $>$ & $>$ & $z$ & $>$ & & $z$ \\
\hline $\begin{array}{c}\frac{\bar{\sigma}}{\bar{\sigma}} \\
\overline{\bar{\omega}} \\
\sum \\
\end{array}$ & 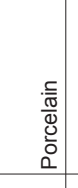 & 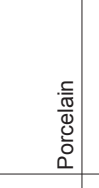 & 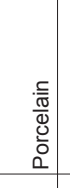 & 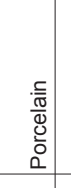 & 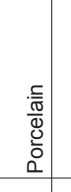 & 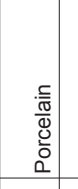 & 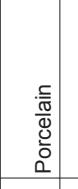 & 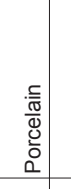 & 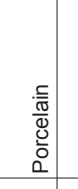 & \begin{tabular}{l|l}
$\frac{5}{\bar{T}}$ \\
$\frac{\pi}{0}$ \\
$\frac{0}{0}$ \\
0
\end{tabular} & 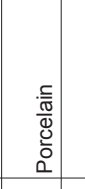 & 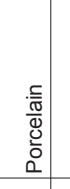 & \begin{tabular}{l|l}
$\frac{c}{\bar{T}}$ \\
$\frac{1}{0}$ \\
$\frac{0}{0}$ \\
0 \\
\end{tabular} & \begin{tabular}{l|l}
$\frac{5}{\bar{T}}$ \\
$\frac{1}{0}$ \\
$\frac{0}{0}$ \\
0
\end{tabular} & 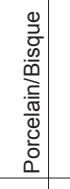 & 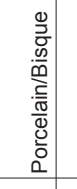 & 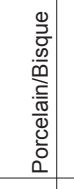 & 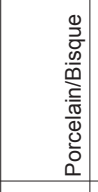 & 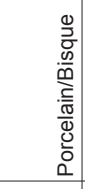 & 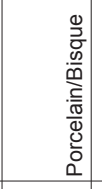 & 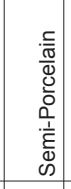 & 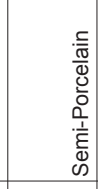 & 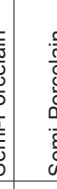 & 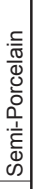 \\
\hline 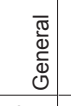 & 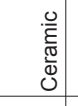 & 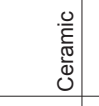 & 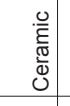 & 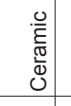 & 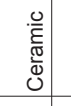 & 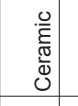 & 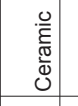 & 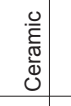 & 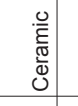 & 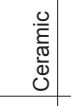 & 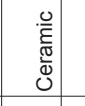 & 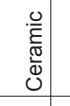 & 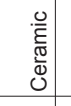 & 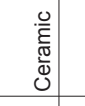 & $\begin{array}{l}0 \\
\underline{E} \\
\overline{\tilde{E}} \\
\mathcal{O}\end{array}$ & 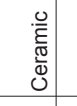 & 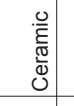 & 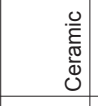 & 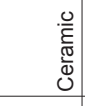 & 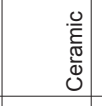 & $\begin{array}{l}0 \\
\bar{E} \\
\bar{w} \\
\bar{w} \\
0 \\
\end{array}$ & 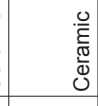 & 豙 & | \\
\hline 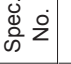 & ஃ̊ & & $\bar{s}$ & ธิ & & $\bar{\delta}$ & ธิ & \&̊ & t & & & & & 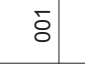 & & & & & & & ธิ & $\stackrel{\nwarrow}{8}$ & $£$ & 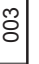 \\
\hline $\begin{array}{l}\mathscr{\mathscr { D }} \\
\frac{\pi}{0}\end{array}$ & $\stackrel{\bar{o}}{\circ}$ & \begin{tabular}{l}
$\stackrel{2}{0}$ \\
\hdashline
\end{tabular} & $\bar{\circ}$ & $\bar{o}$ & $\overline{\mathrm{o}}$ & ᄒᄒ & $\bar{\delta}$ & $\bar{\sigma}$ & $\bar{\delta}$ & $\begin{array}{l}0 \\
\stackrel{0}{0}\end{array}$ & $\bar{o}$ & $\overline{\mathrm{o}}$ & $\bar{o}$ & $\overline{\mathrm{o}}$ & $\stackrel{\hat{o}}{-}$ & $\bar{\circ}$ & \begin{tabular}{l}
$\stackrel{\swarrow}{\circ}$ \\
\hdashline
\end{tabular} & $\begin{array}{l}\text { 임 } \\
\end{array}$ & $\begin{array}{l}\stackrel{2}{0} \\
\stackrel{0}{\sigma}\end{array}$ & \begin{tabular}{l}
$\stackrel{2}{\circ}$ \\
\hdashline
\end{tabular} & $\stackrel{\bar{o}}{\circ}$ & $\begin{array}{l}0 \\
\stackrel{0}{\circ}\end{array}$ & $\dot{c}$ & চे \\
\hline$\frac{\pi}{2}$ & $\overleftarrow{0}$ & 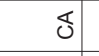 & $\overleftarrow{0}$ & $\delta$ & $\widehat{J}$ & $\delta$ & $\delta$ & $\delta$ & $\delta$ & $\delta$ & $\delta$ & 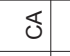 & $\delta$ & $\delta$ & U & प्य & U & U. & U & एu & 0 & 0 & & 0 \\
\hline 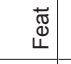 & & & & & & & & & & & & & & & & & & & & & & & & \\
\hline 产 & $\sim$ & $N$ & $m$ & $m$ & 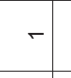 & $N$ & $N$ & $N$ & $N$ & $\sim$ & $m$ & - & $\sim$ & 0 & 0 & - & $m$ & $\sim$ & $m$ & - & - & - & 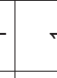 & - \\
\hline 急占 & ป̃ & $\begin{array}{l}\text { ปे } \\
\text { วิ }\end{array}$ & ป̃ & ป̃ & 岀 & य̄ & 岀 & यू & यू & 㟧 & $\overline{\breve{u}}$ & ખّ & ษ్ & $\begin{array}{l}\overline{4} \\
\end{array}$ & $\begin{array}{l}\bar{c} \\
د\end{array}$ & $\stackrel{\pi}{5}$ & $\begin{array}{l}5 \\
د\end{array}$ & Õ & ป̃ & $\overline{\mathrm{u}}$ & $\begin{array}{l}\bar{\alpha} \\
\end{array}$ & $\stackrel{m}{2}$ & $\AA$ & 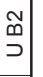 \\
\hline$\vec{\Xi}$ & 命 & 흥 & $\begin{array}{l}\infty \\
\circ \\
\circ\end{array}$ & $\begin{array}{l}\text { 吕 } \\
\end{array}$ & $\stackrel{t}{0}$ & $\stackrel{0}{\circ}$ & $\stackrel{8}{\circ}$ & $\stackrel{0}{\circ}$ & $\stackrel{8}{\circ}$ & $\stackrel{8}{\circ}$ & $\stackrel{0}{0}$ & 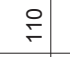 & $\stackrel{N}{\rightleftharpoons}$ & $\stackrel{0}{0}$ & $\frac{0}{\delta}$ & $\begin{array}{l}0 \\
0 \\
0\end{array}$ & : & ลे & $\begin{array}{l}\infty \\
\stackrel{0}{\circ}\end{array}$ & ఫ & $\bar{\delta}$ & 志 & & 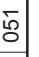 \\
\hline $\begin{array}{l}0 \\
2 \\
0 \\
0 \\
\frac{0}{0} \\
\frac{0}{50} \\
0 \\
0\end{array}$ & 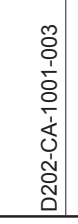 & 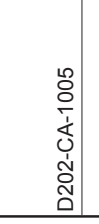 & 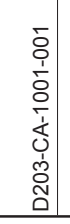 & 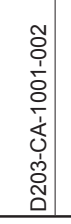 & $\begin{array}{c}\bar{\delta} \\
\bar{T} \\
\bar{d} \\
\overline{1} \\
\overline{0} \\
\bar{\omega} \\
\end{array}$ & 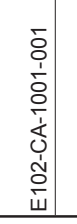 & 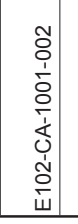 & 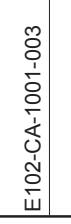 & 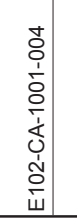 & 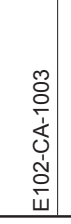 & $\mid \begin{array}{c}\bar{o} \\
\bar{d} \\
\grave{d} \\
\tilde{j} \\
\bar{w} \\
\bar{w}\end{array}$ & $\begin{array}{l}\bar{\delta} \\
\bar{o} \\
\bar{d} \\
\underline{1} \\
\bar{i} \\
\tilde{\Psi}\end{array}$ & $\begin{array}{l}\bar{\delta} \\
\overline{0} \\
\dot{j} \\
\dot{\tilde{y}} \\
\tilde{\Psi} \\
\end{array}$ & 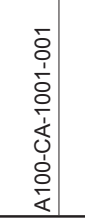 & $\begin{array}{l}\hat{o} \\
\stackrel{亠}{\dot{u}} \\
\dot{u} \\
\dot{0} \\
\dot{\alpha} \\
\end{array}$ & 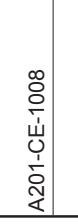 & 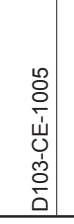 & 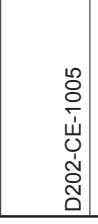 & 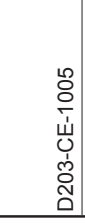 & 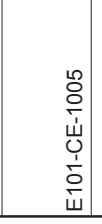 & 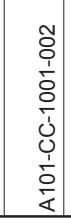 & 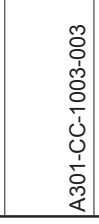 & 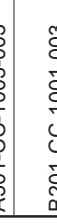 & مإِ \\
\hline
\end{tabular}




\begin{tabular}{|c|c|c|c|c|c|c|c|c|c|c|c|c|c|c|c|c|}
\hline & 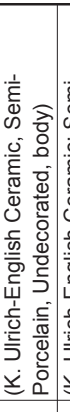 & 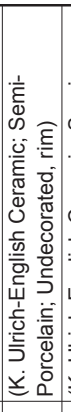 & 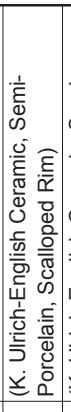 & 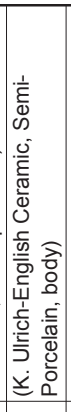 & 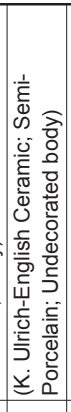 & 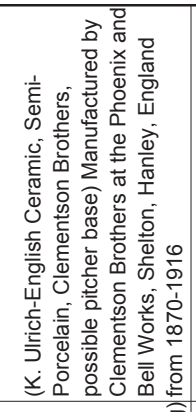 & & 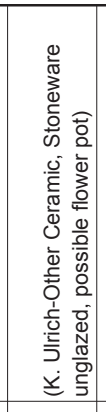 & 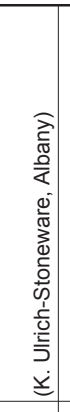 & 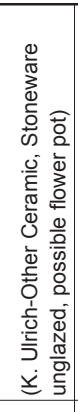 & 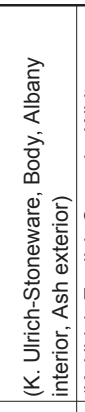 & 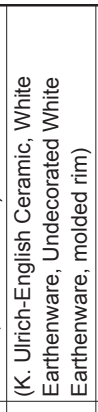 & 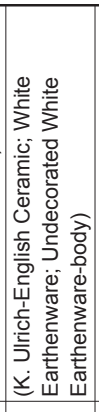 & 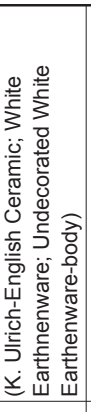 & 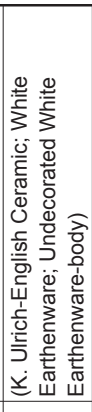 & 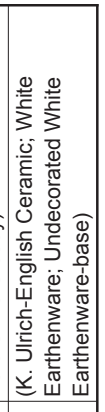 \\
\hline $\begin{array}{l}\frac{0}{\pi} \\
0 \\
\end{array}$ & $\begin{array}{l}\stackrel{+}{\infty} \\
\stackrel{\infty}{\leftarrow} \\
\end{array}$ & $\begin{array}{r}+ \\
\stackrel{+}{\infty} \\
\stackrel{\infty}{\leftarrow} \\
\end{array}$ & 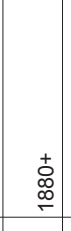 & $\begin{array}{c}\text { 离 } \\
\stackrel{\infty}{c} \\
\end{array}$ & 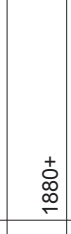 & 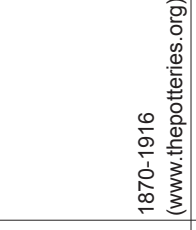 & 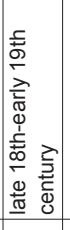 & & 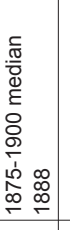 & & 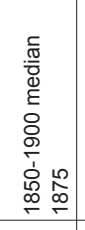 & 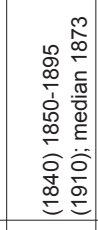 & 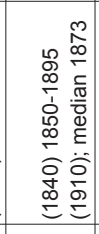 & 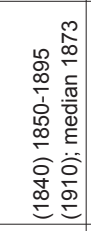 & 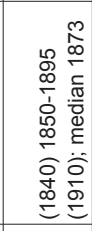 & 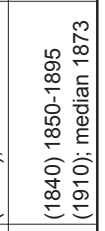 \\
\hline $\begin{array}{l}\widehat{N} \\
\hat{J} \\
\bar{\xi}\end{array}$ & 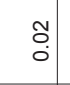 & 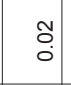 & $\stackrel{8}{\circ}$ & $\stackrel{8}{\circ}$. & : & $\begin{array}{c}\infty \\
\stackrel{\infty}{p} \\
\stackrel{p}{*}\end{array}$ & $\frac{0}{\circ}$ & $\begin{array}{l}\infty \\
\stackrel{0}{0}\end{array}$ & $\stackrel{\uparrow}{0}$ & 帒 & $\overline{\hat{s}}$ & $\begin{array}{l}\text { o. } \\
0 \\
0\end{array}$ & $\begin{array}{l}\text { o. } \\
\text { o }\end{array}$ & $\begin{array}{l}q \\
0 \\
0\end{array}$ & ס. & | \\
\hline$\overline{0}$ & - & - & - & - & $m$ & - & - & - & - & $m$ & - & - & m & - & - & - \\
\hline 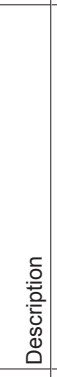 & 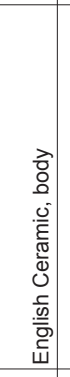 & 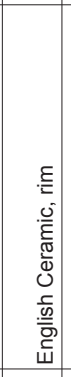 & 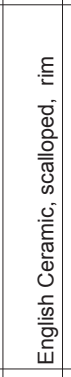 & 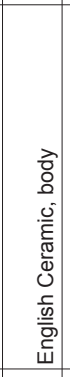 & 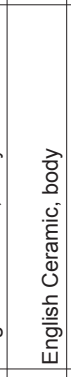 & 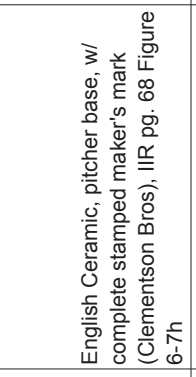 & 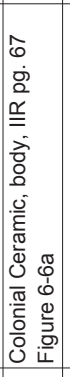 & 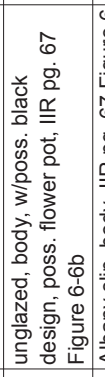 & 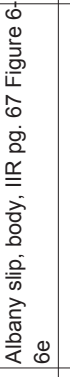 & 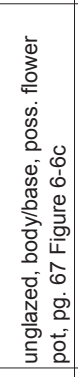 & 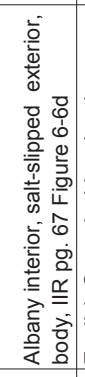 & 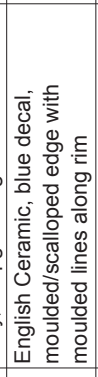 & 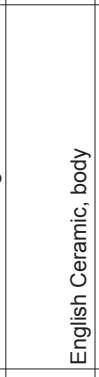 & 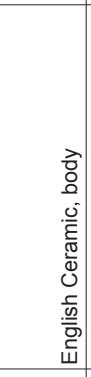 & 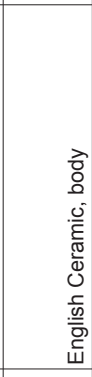 & 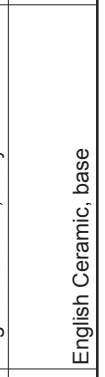 \\
\hline $\begin{array}{l}0 \\
\\
\end{array}$ & $z$ & $z$ & $>$ & $z$ & $z$ & $>$ & $z$ & $>$ & $z$ & $z$ & $z$ & $>$ & $z$ & $z$ & $z$ & $z$ \\
\hline $\begin{array}{l}\overline{\bar{\sigma}} \\
\overline{\bar{\omega}} \\
\overline{\frac{\pi}{2}}\end{array}$ & 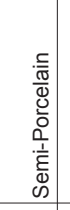 & 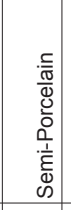 & 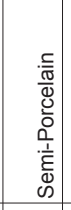 & 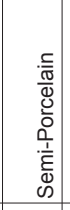 & 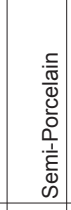 & 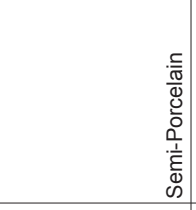 & 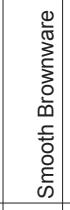 & 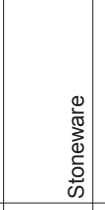 & 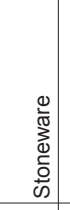 & 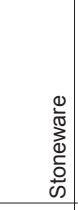 & 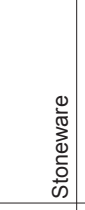 & 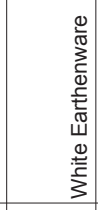 & 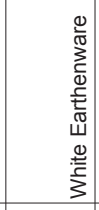 & 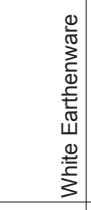 & 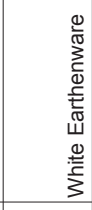 & 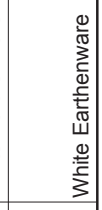 \\
\hline $\begin{array}{l}\bar{\sigma} \\
\bar{w} \\
\overline{0} \\
0 \\
0 \\
\end{array}$ & 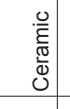 & 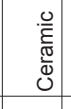 & 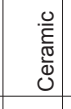 & 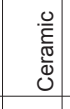 & 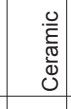 & 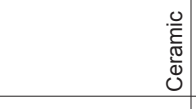 & 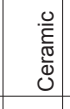 & 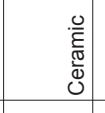 & 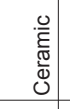 & 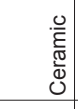 & 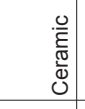 & 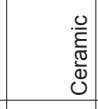 & 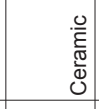 & 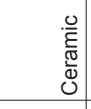 & 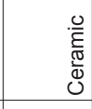 & 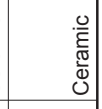 \\
\hline غٌ & ๑ొ & $\stackrel{\circ}{\circ}$ & ธิ & & \& & ঃ & & & & & & & $\overline{8}$ & & $\overline{8}$ & ฉิ \\
\hline $\begin{array}{c}\mathscr{D} \\
\frac{\pi}{0}\end{array}$ & $\bar{\sigma}$ & $\overline{\mathrm{o}}$ & \begin{tabular}{l}
0 \\
$\stackrel{0}{o}$ \\
\hdashline
\end{tabular} & $\infty$ & $\bar{\alpha}$ & $\bar{\sigma}$ & $\bar{o}$ & $\begin{array}{l}0 \\
\stackrel{0}{0}\end{array}$ & $\bar{\circ}$ & s. & চ̄ & $\begin{array}{l}m \\
\stackrel{0}{0}\end{array}$ & $\bar{\delta}$ & $\bar{\delta}$ & $\stackrel{\circ}{\circ}$ & 훙 \\
\hline$\frac{\pi}{2}$ & 0 & 0 & 0 & 0 & 0 & 0 & 8 & 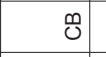 & 0 & $\begin{array}{l}0 \\
0 \\
\end{array}$ & $\tilde{0}$ & $\begin{array}{l}0 \\
\end{array}$ & 0 & 0 & O & 0 \\
\hline 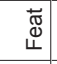 & & & & & & & & & $\infty$ & & & & & & & \\
\hline 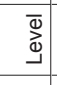 & $\sim$ & $N$ & $N$ & $\sim$ & $r$ & $\nabla$ & $\tau$ & $r$ & $m$ & - & $\tau$ & 0 & - & $r$ & - & - \\
\hline 害占 & $\begin{array}{l}\bar{J} \\
\partial\end{array}$ & $\begin{array}{l}\tilde{O} \\
\text { J }\end{array}$ & $\begin{array}{l}\mathrm{U} \\
\mathrm{J}\end{array}$ & ปิ & य & ખّ & $\begin{array}{l}\mathrm{v} \\
\text { כ }\end{array}$ & $\stackrel{8}{5}$ & $\begin{array}{l}\overline{0} \\
0\end{array}$ & $\tilde{\mathcal{O}}$ & ษั & $\stackrel{\Sigma}{5}$ & $\stackrel{\Sigma}{5}$ & $\stackrel{7}{\beth}$ & $\stackrel{\text { \} }{5}} &{\text { 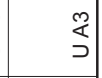 }} \\
{\hline \text { s. }} &{\text { 吉 }} &{\begin{array}{ll}\multirow{2}{*}{} \\
\end{array}} &{\begin{array}{l}\stackrel{N}{0} \\
\end{array}} &{\text { ò }} &{\stackrel{t}{\sigma}} &{\stackrel{\circ}{=}} &{\text { 今 }} &{\text { 产 }} &{\text { 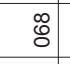 }} &{\text { 今े }} &{\stackrel{\circ}{\circ}} &{\stackrel{\circ}{\circ}} &{\overline{\mathrm{d}}} &{\stackrel{8}{0}} &{\text { 产 }} &{\text { 范 }} \\
{\hline \begin{array}{l}\dot{0} \\
2 \\
0 \\
0 \\
\overline{0} \\
\frac{0}{\pi} \\
\overline{0} \\
0\end{array}} &{\text { 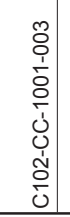 }} &{\text { 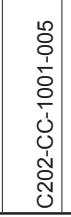 }} &{\text { 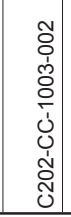 }} &{\text { 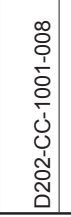 }} &{\text { 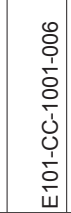 }} &{\text { 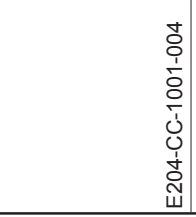 }} &{\text { 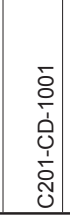 }} &{\text { 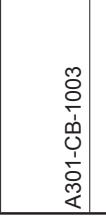 }} &{\text { 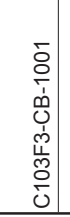 }} &{\text { 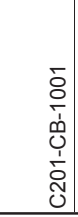 }} &{\text { 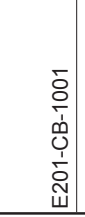 }} &{\begin{array}{l}0 \\
0 \\
0 \\
\dot{d} \\
0 \\
0 \\
0 \\
\end{array}} &{\begin{array}{l}\overline{0} \\
\vdots \\
\vdots \\
0 \\
\vdots \\
0 \\
0 \\
\vdots \\
\frac{0}{4} \\
\end{array}} &{\text { 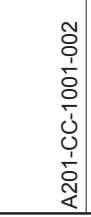 }} &{\text { 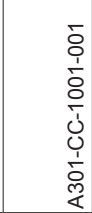 }} &{\text { 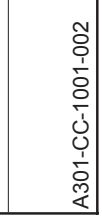 }} \\
$\hline
\end{tabular}




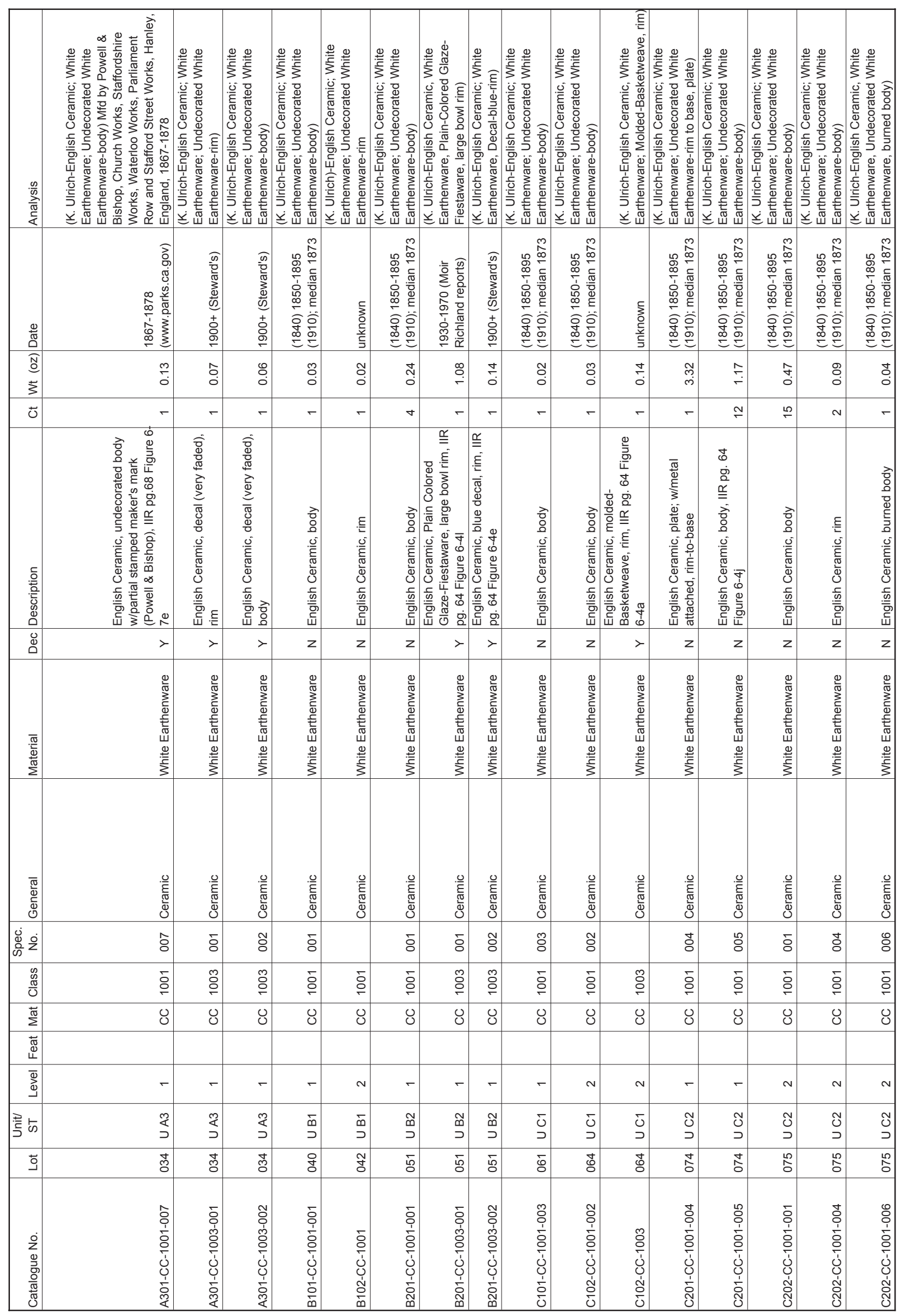




\begin{tabular}{|c|c|c|c|c|c|c|c|c|c|c|c|c|c|c|c|c|}
\hline : & 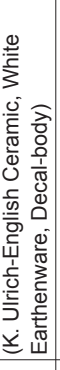 & 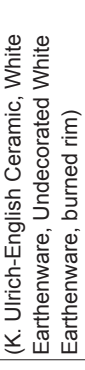 & 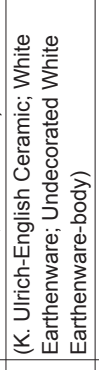 & 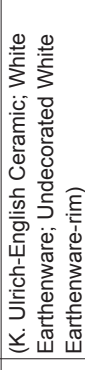 & 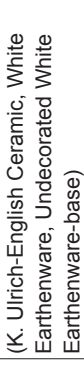 & 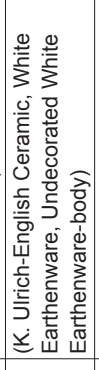 & 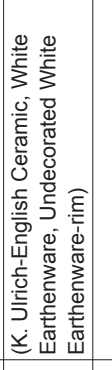 & 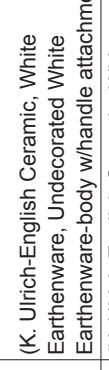 & 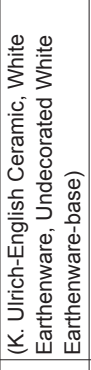 & 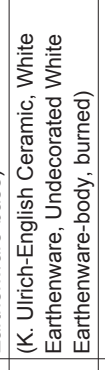 & 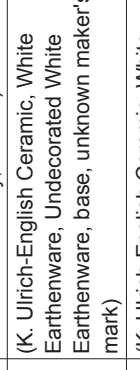 & 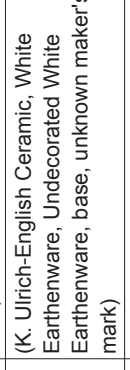 & 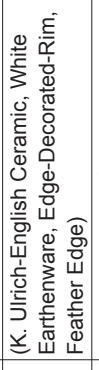 & 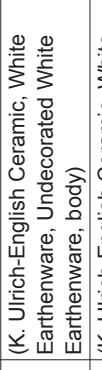 & 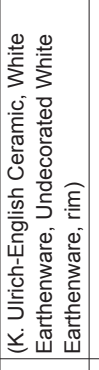 & 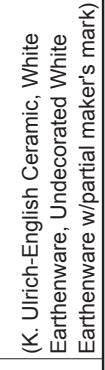 \\
\hline $\begin{array}{l}\frac{0}{5} \\
\frac{\pi}{0} \\
\end{array}$ & 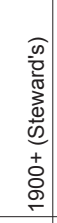 & 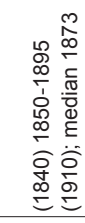 & 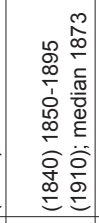 & 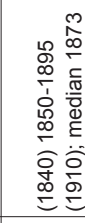 & 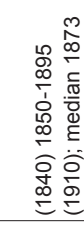 & 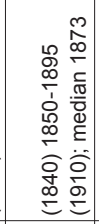 & 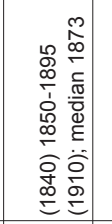 & 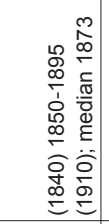 & 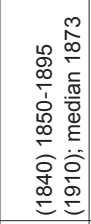 & 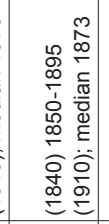 & 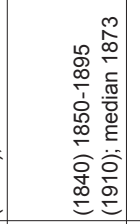 & 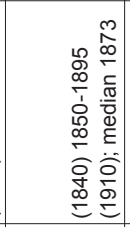 & 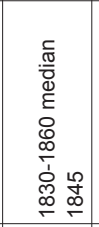 & 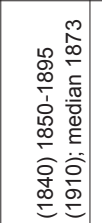 & 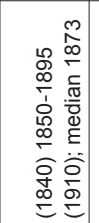 & 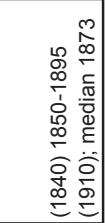 \\
\hline $\begin{array}{l}\widehat{N} \\
0 \\
\vdots\end{array}$ & $\begin{array}{l}\infty \\
0 \\
0 \\
\end{array}$ & $\stackrel{\text { og }}{0}$ & 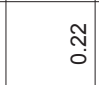 & $\stackrel{\circ}{\circ}$ & ठ্. & $\begin{array}{l}0 \\
0 \\
0\end{array}$ & ָָ๊ & 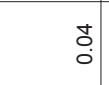 & $\begin{array}{l}0 \\
0 \\
0\end{array}$ & $\stackrel{0}{\circ}$ & $\begin{array}{l}\tilde{1} \\
0 \\
0\end{array}$ & 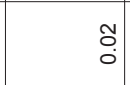 & $\stackrel{m}{\circ}$ & $\begin{array}{l}0 \\
0 \\
0 \\
\end{array}$ & $\begin{array}{l} \\
\text { ơ } \\
0\end{array}$ & $\begin{array}{l}8 \\
\circ \\
\circ\end{array}$ \\
\hline$\overline{0}$ & $N$ & - & $\nabla$ & - & - & の & $m$ & $r$ & - & - & - & $r$ & - & - & - & 5 \\
\hline 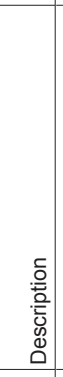 & 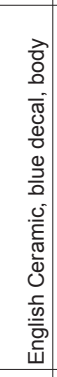 & 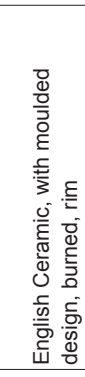 & 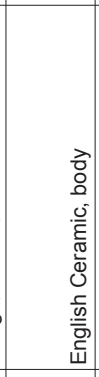 & 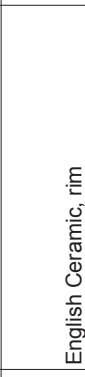 & 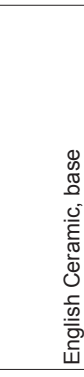 & 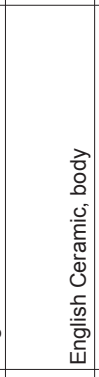 & 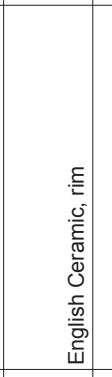 & 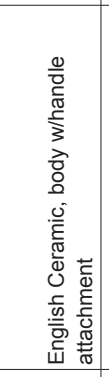 & 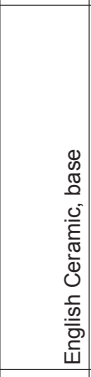 & 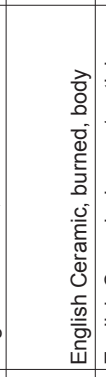 & 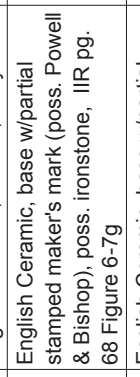 & 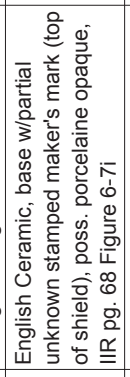 & 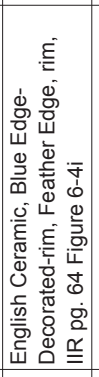 & 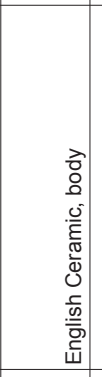 & 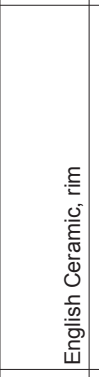 & 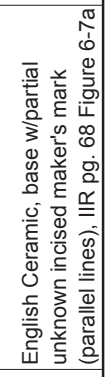 \\
\hline $\begin{array}{l}0 \\
\\
\end{array}$ & $>$ & $>$ & $z$ & $z$ & $z$ & $z$ & $z$ & $z$ & $z$ & $z$ & $>$ & $>$ & $>$ & $z$ & $z$ & $>$ \\
\hline $\begin{array}{l}\frac{\mathrm{w}}{\mathrm{w}} \\
\frac{\mathrm{w}}{\mathrm{w}} \\
\overline{2}\end{array}$ & 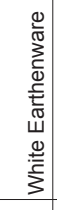 & 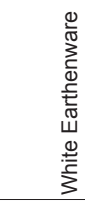 & 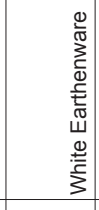 & 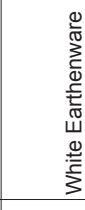 & 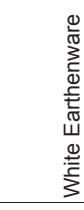 & 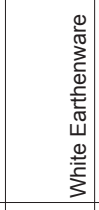 & 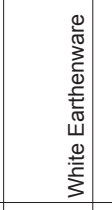 & 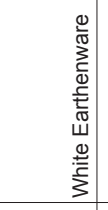 & 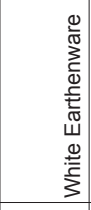 & 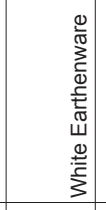 & 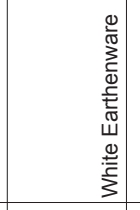 & 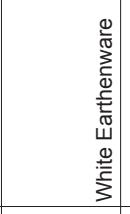 & 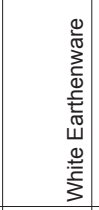 & 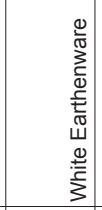 & 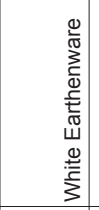 & 恚 \\
\hline 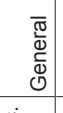 & $\begin{array}{l}0 \\
\bar{E} \\
\frac{\mathbb{w}}{\mathbb{N}} \\
\mathcal{U} \\
\end{array}$ & 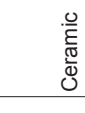 & 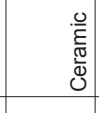 & 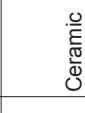 & 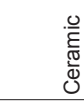 & 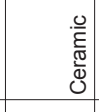 & 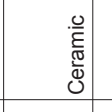 & 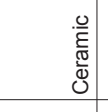 & 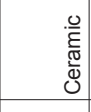 & 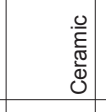 & $\begin{array}{l}0 \\
\stackrel{0}{\tilde{E}} \\
\overline{\tilde{d}} \\
\mathcal{U}\end{array}$ & 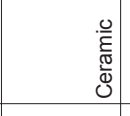 & 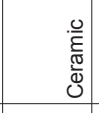 & 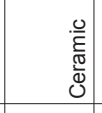 & 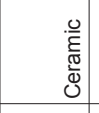 & 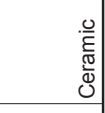 \\
\hline 它 & $\overline{8}$ & $\stackrel{\square}{\circ}$ & $\overline{8}$ & ธิ & ๕̊ & ธิ & ه̊ & ঃั & $\stackrel{\circ}{\circ}$ & $\stackrel{\infty}{\circ}$ & : & 응 & ธิ & ธิ & ฉ̊ & $\overline{8}$ \\
\hline $\begin{array}{c}\mathscr{w} \\
\frac{\pi}{0} \\
\end{array}$ & $\begin{array}{l}0 \\
\stackrel{0}{\circ} \\
\end{array}$ & $\stackrel{\text { \% }}{\circ}$ & 容 & ๙্े & $\stackrel{\bar{\circ}}{\circ}$ & চ̄ & $\stackrel{\bar{\sigma}}{\circ}$ & $\overline{\mathrm{o}}$ & $\stackrel{\bar{\sigma}}{-}$ & $\stackrel{\bar{\sigma}}{\circ}$ & $\stackrel{\bar{o}}{\circ}$ & $\overline{\grave{\sigma}}$ & $\begin{array}{l}0 \\
\stackrel{0}{\circ} \\
\end{array}$ & চे & 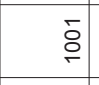 & চᄒ \\
\hline$\sum^{\pi}$ & 0 & O & 0 & O & O & 0 & 0 & 0 & 0 & 0 & 0 & 0 & 0 & 0 & 0 & 0 \\
\hline \begin{tabular}{|c|}
$\vec{\Phi}$ \\
$\vec{L}$
\end{tabular} & & & & & & & & & & & & & & & & \\
\hline 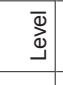 & $N$ & $\sim$ & $m$ & $m$ & N & m & $m$ & $\infty$ & $m$ & $\infty$ & $m$ & $m$ & m & + & + & - \\
\hline 急占 & $\begin{array}{l}\tilde{O} \\
\text { כ }\end{array}$ & ปั & $\begin{array}{l}\text { ป } \\
\text { כ }\end{array}$ & ป & ذे & ذ̄ & ذे & ذे & ড̀ & à & à & ذ̄ & $\overline{\grave{a}}$ & ذ̀ & ذ̀ & ปે \\
\hline 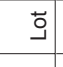 & \begin{tabular}{ll|}
\multirow{2}{*}{} \\
5 \\
\end{tabular} & $\begin{array}{l}2 \\
5 \\
0\end{array}$ & \begin{tabular}{ll|} 
\\
\multirow{2}{*}{}
\end{tabular} & ฉ̊ & $\begin{array}{l}\infty \\
\stackrel{0}{0}\end{array}$ & : & . & . & . & 8 & . & 8. & 용 & $\stackrel{8}{\circ}$ & $\stackrel{8}{\circ}$ & ஜ \\
\hline 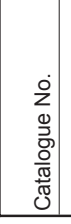 & 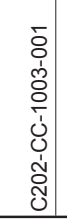 & 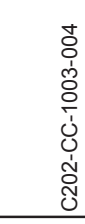 & 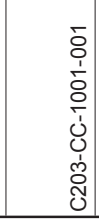 & 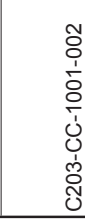 & 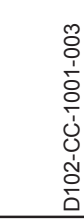 & 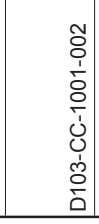 & $\begin{array}{l}0 \\
0 \\
0 \\
\vdots \\
0 \\
\vdots \\
0 \\
0 \\
0 \\
0 \\
0 \\
\end{array}$ & 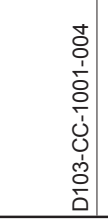 & 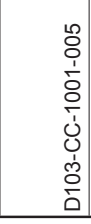 & $\begin{array}{l}0 \\
0 \\
0 \\
0 \\
0 \\
0 \\
0 \\
0 \\
0 \\
0 \\
0\end{array}$ & 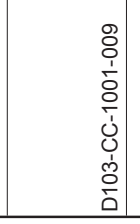 & 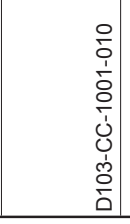 & 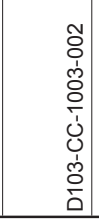 & 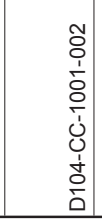 & $\begin{array}{l}\text { ồ } \\
\vdots \\
\vdots \\
\vdots \\
\dot{j} \\
0 \\
\vdots \\
\vdots \\
\vdots \\
\vdots\end{array}$ & 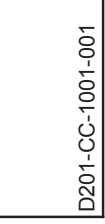 \\
\hline
\end{tabular}




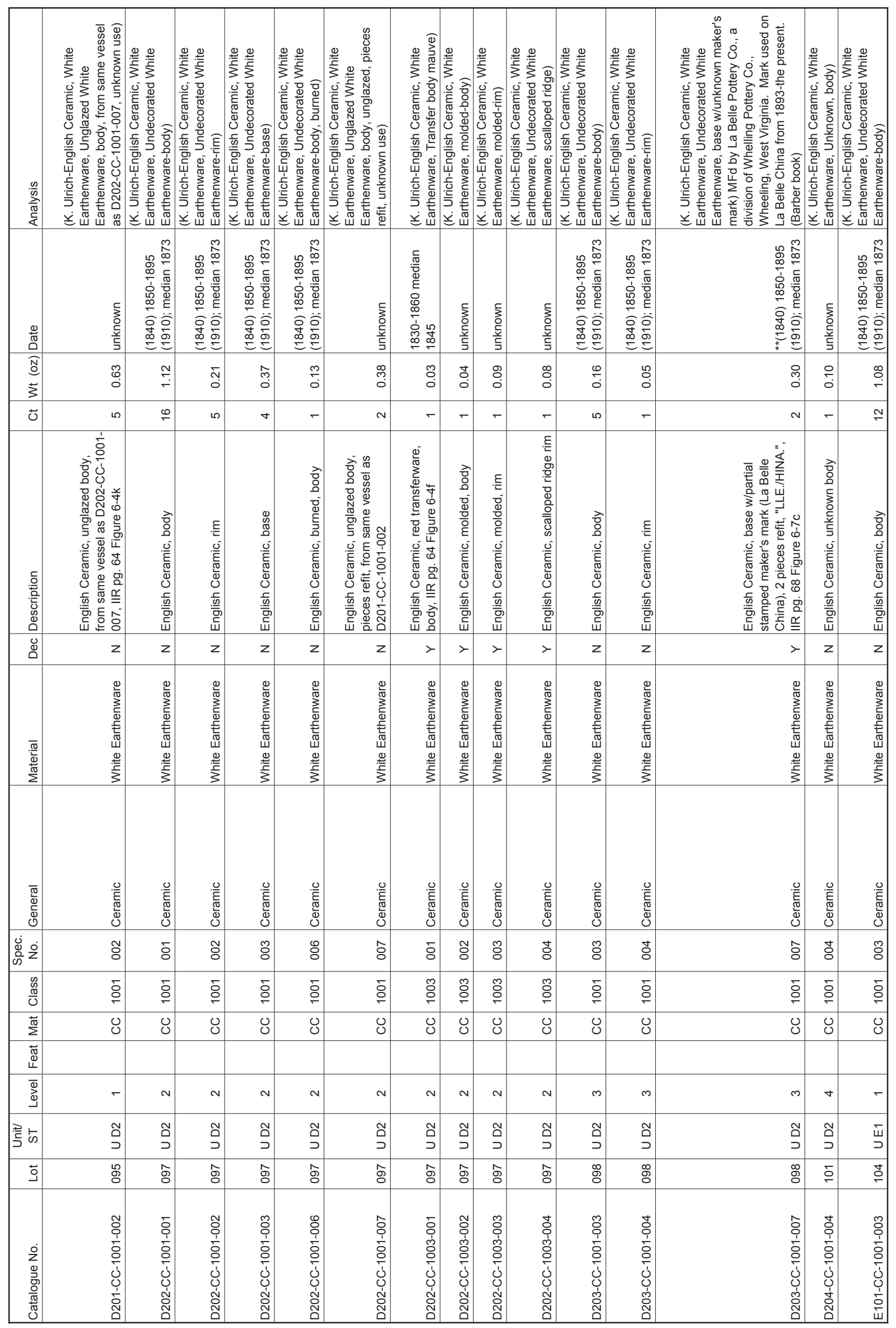




\begin{tabular}{|c|c|c|c|c|c|c|c|c|c|c|c|c|c|c|c|c|c|}
\hline & 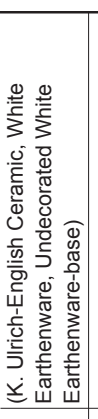 & 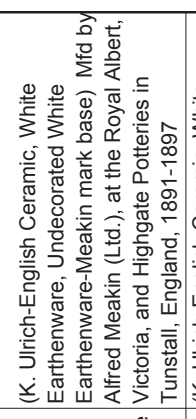 & 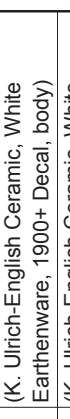 & 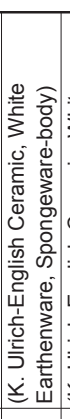 & 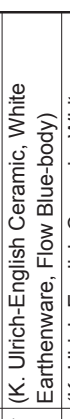 & 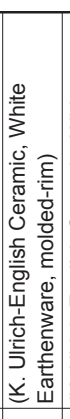 & 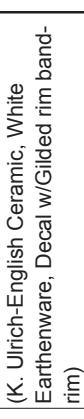 & 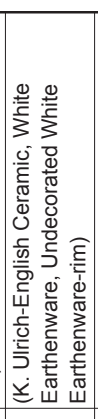 & 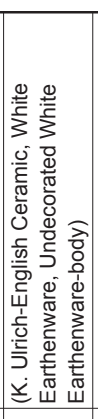 & 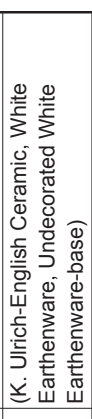 & 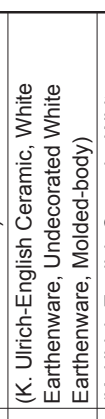 & 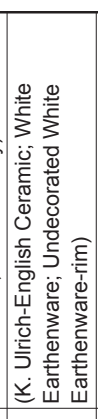 & 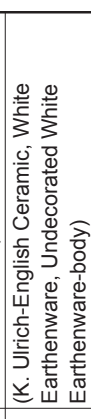 & 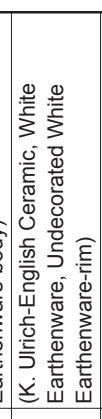 & 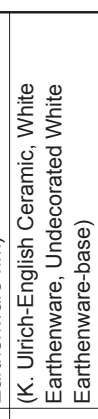 & 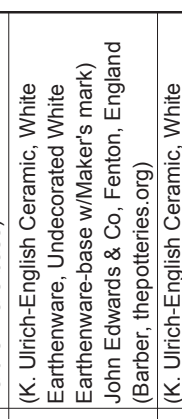 & 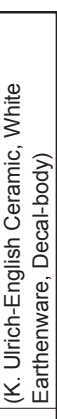 \\
\hline 步 & 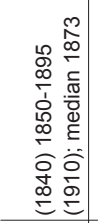 & 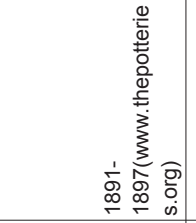 & 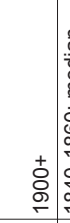 & 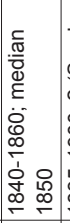 & 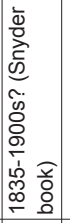 & 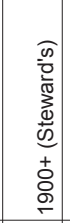 & 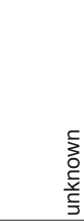 & 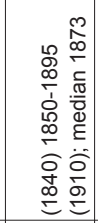 & 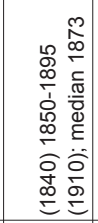 & 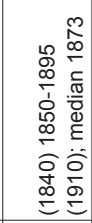 & 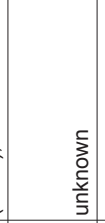 & 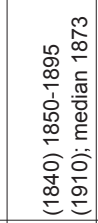 & 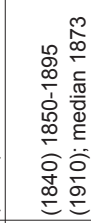 & 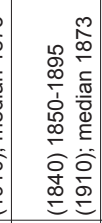 & 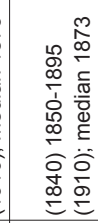 & 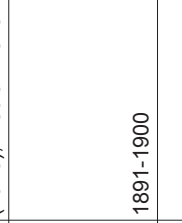 & 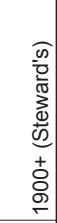 \\
\hline $\begin{array}{l}\widehat{N} \\
0 \\
\overrightarrow{3}\end{array}$ & $\stackrel{m}{\circ}$ & $\begin{array}{l}\hat{0} \\
0\end{array}$ & $\begin{array}{l}0 \\
0 \\
0\end{array}$ & $\hat{o}$ & $\tilde{o}_{0}$ & 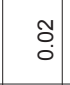 & $\stackrel{\text { : }}{\circ}$ & $\stackrel{5}{\circ}$ & 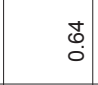 & $\stackrel{m}{\circ}$ & 品 & $\begin{array}{l}0 \\
\stackrel{0}{0} \\
\stackrel{2}{0}\end{array}$ & ֶֶ? & $\begin{array}{l}8 \\
0 \\
0\end{array}$ & 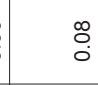 & ז. & $\begin{array}{l}\text { to } \\
0 \\
0\end{array}$ \\
\hline$\tilde{0}$ & - & - & $\sim$ & - & $r$ & $r$ & - & $N$ & $\simeq$ & - & $r$ & - & o & - & $N$ & - & - \\
\hline 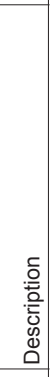 & 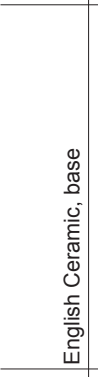 & 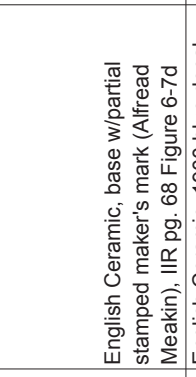 & 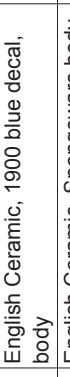 & 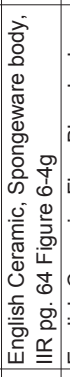 & 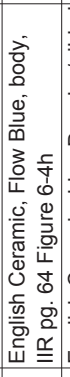 & 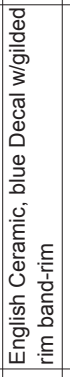 & 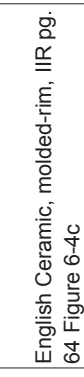 & 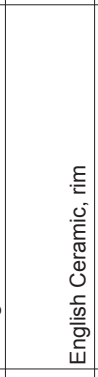 & 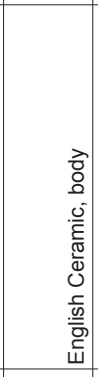 & 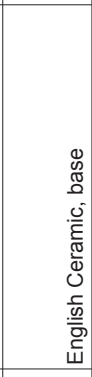 & 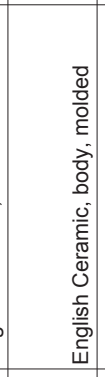 & 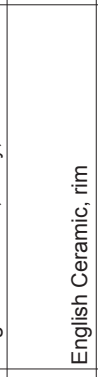 & 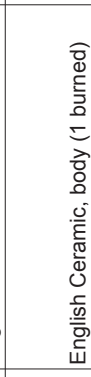 & 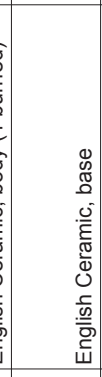 & 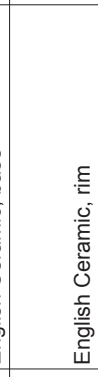 & 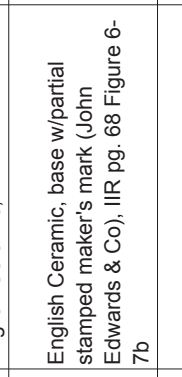 & 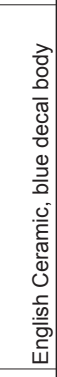 \\
\hline$\stackrel{0}{8}$ & $z$ & $>$ & $>$ & $>$ & $>$ & $>$ & $>$ & $z$ & $z$ & $z$ & $>$ & $z$ & $z$ & $z$ & $z$ & $>$ & $>$ \\
\hline $\begin{array}{l}\overline{\widetilde{\sigma}} \\
\bar{\Phi} \\
\overline{\mathbb{N}} \\
\end{array}$ & 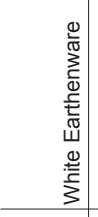 & 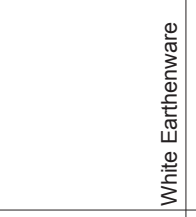 & 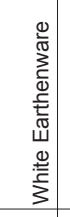 & 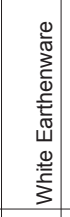 & 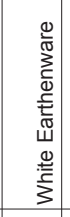 & 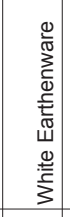 & 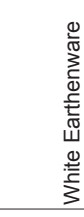 & 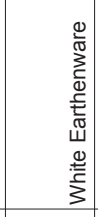 & 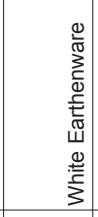 & 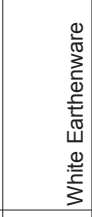 & 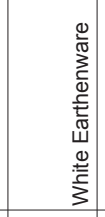 & 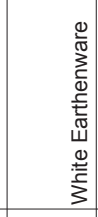 & 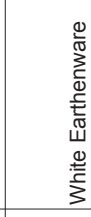 & 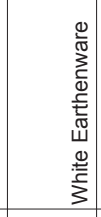 & 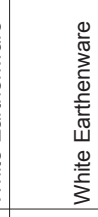 & 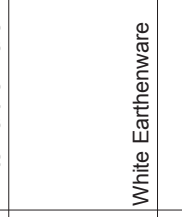 & 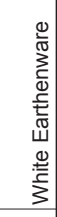 \\
\hline $\begin{array}{l}\overline{\frac{\pi}{\sigma}} \\
\bar{\omega} \\
\overline{0} \\
0\end{array}$ & $\begin{array}{l}0 \\
\bar{E} \\
\overline{\tilde{\omega}} \\
\mathcal{U} \\
\end{array}$ & 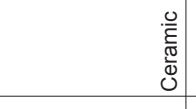 & 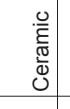 & 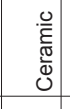 & 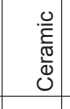 & 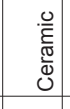 & 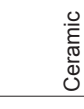 & 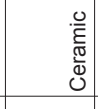 & 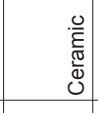 & 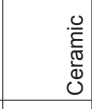 & 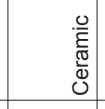 & 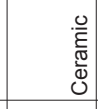 & 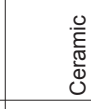 & 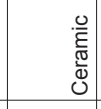 & 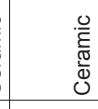 & 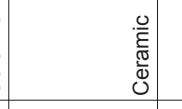 & 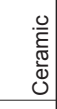 \\
\hline ه্் & $\stackrel{+}{\circ}$ & $\stackrel{8}{8}$ & $\overline{8}$ & ธิ & ฉ̊ & ث & $\stackrel{8}{\circ}$ & $\overline{8}$ & ธี & \% & & & $\bar{o}$ & ธิ & \% & $\stackrel{ \pm}{\Delta}$ & 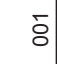 \\
\hline $\begin{array}{c}0 \\
0 \\
\frac{\pi}{U}\end{array}$ & $\overline{\mathrm{o}}$ & $\bar{\sigma}$ & \%̊ & \begin{tabular}{l}
0 \\
$\stackrel{0}{o}$ \\
\hdashline
\end{tabular} & \begin{tabular}{l}
0 \\
$\stackrel{0}{o}$ \\
\hdashline
\end{tabular} & $\begin{array}{l}0 \\
\stackrel{0}{o} \\
\end{array}$ & $\stackrel{\text { \% }}{\circ}$ & $\bar{o}$ & $\bar{\sigma}$ & $\bar{\circ}$ & $\begin{array}{l}0 \\
\stackrel{0}{o} \\
\end{array}$ & $\bar{\sigma}$ & $\bar{\circ}$ & $\bar{\delta}$ & 흥 & $\bar{o}$ & $\begin{array}{l}m \\
\stackrel{m}{\circ}\end{array}$ \\
\hline$\frac{\vec{\pi}}{2}$ & 0 & 0 & 0 & 0 & 0 & 0 & 0 & 8 & 0 & O & 0 & 0 & O & 0 & 8 & 0 & 0 \\
\hline 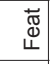 & & & & & & & & & & & & & & & & & \\
\hline$\overline{\mathrm{g}} \overline{\mathrm{g}}$ & - & - & - & - & - & - & - & $N$ & $N$ & $\sim$ & $N$ & $m$ & - & $r$ & - & - & - \\
\hline 胥的 & $\stackrel{\bar{u}}{د}$ & $\stackrel{\bar{u}}{د}$ & ড్ & Шّ & Шّ & यّ & 岀 & यّ & यّ & Шّ & 山्य & 㟧 & แี & ખّ & ખّ & $\stackrel{\widetilde{\Psi}}{\mathrm{J}}$ & แี \\
\hline ఫ & $\stackrel{0}{\circ}$ & $\stackrel{+}{\circ}$ & to & ક. & f. & t. & $\stackrel{\leftrightarrow}{\circ}$ & $\stackrel{8}{0}$ & $\stackrel{0}{\circ}$ & $\stackrel{\circ}{\circ}$ & $\stackrel{8}{\circ}$ & 웅 & 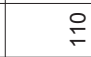 & $\stackrel{\circ}{\circ}$ & $\stackrel{\circ}{ }$ & $\stackrel{2}{\circ}$ & $\stackrel{\circ}{ }$ \\
\hline 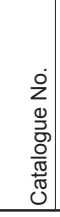 & 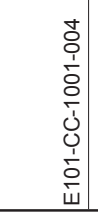 & 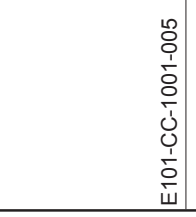 & 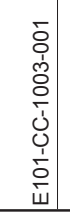 & 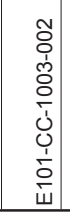 & 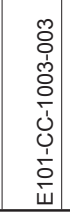 & 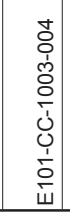 & 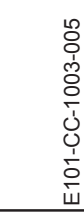 & 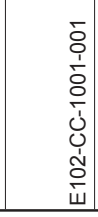 & 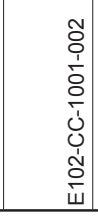 & 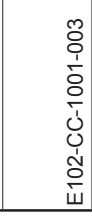 & 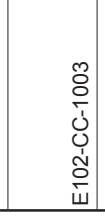 & 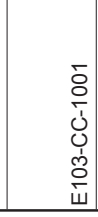 & 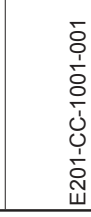 & 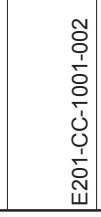 & 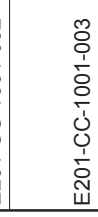 & 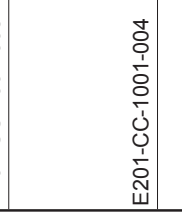 & 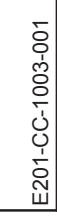 \\
\hline
\end{tabular}




\begin{tabular}{|c|c|c|c|c|c|c|c|c|c|c|c|c|c|c|c|c|c|c|c|c|c|c|c|c|c|}
\hline $\begin{array}{l}\frac{w}{0} \\
\frac{0}{20} \\
\frac{\tilde{c}}{4}\end{array}$ & 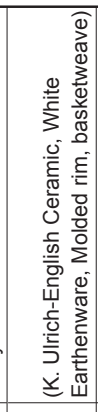 & 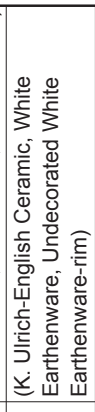 & 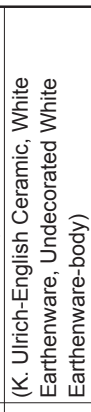 & 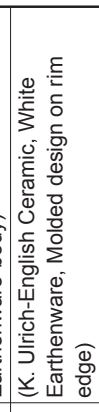 & 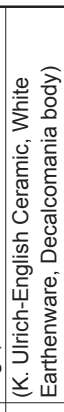 & 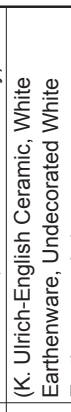 & & 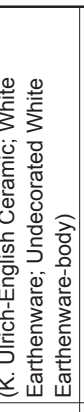 & 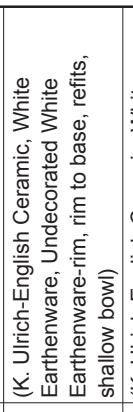 & 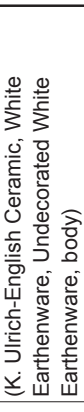 & 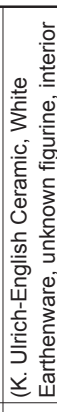 & 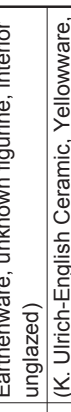 & 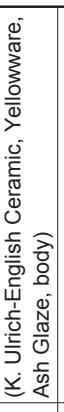 & & & & & & & & & & & & \\
\hline 造 & $\begin{array}{l}\text { ज्ञ } \\
0 \\
\text { 亲 } \\
\end{array}$ & 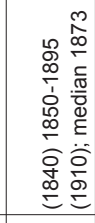 & 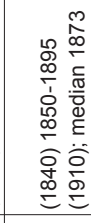 & 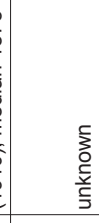 & 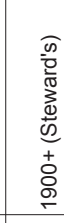 & & 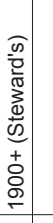 & 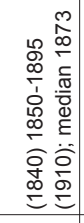 & 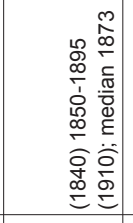 & 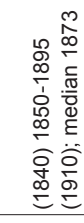 & & 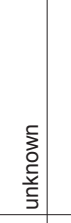 & 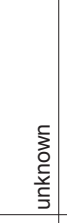 & & & & & & & & & & & & \\
\hline $\begin{array}{l}\widehat{\widehat{N}} \\
\hat{3} \\
\overrightarrow{3}\end{array}$ & ז. & ô. & 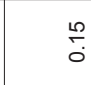 & $\stackrel{8}{\circ}$ & ֻ. & & $\begin{array}{l}\Omega \\
\delta \\
0 \\
\end{array}$ & $\begin{array}{l}0 \\
: \\
0 \\
0\end{array}$ & $\underset{\mathfrak{N}}{\mathbb{N}}$ & $\begin{array}{l}\text { No } \\
\text { ¿. }\end{array}$ & & $\begin{array}{l}\hat{0} \\
0 \\
\end{array}$ & & \begin{tabular}{|l|}
0 \\
\hdashline \\
0 \\
\end{tabular} & $\begin{array}{l}f \\
0 \\
0\end{array}$ & $\begin{array}{l}1 \\
\delta \\
\vdots\end{array}$ & & \begin{tabular}{ccc}
\multirow{\infty}{\infty}{} \\
$\vdots$ \\
0
\end{tabular} & \begin{tabular}{|l|l}
$y$ \\
$\vdots$ \\
$\vdots$ \\
0
\end{tabular} & $\stackrel{+}{\circ}$ & $\grave{0}$ & ঙ. & 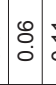 & & 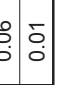 \\
\hline$\tilde{0}$ & - & N & 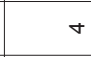 & $r$ & - & & - & - & $N$ & - & & $N$ & - & m & - & -0 & ब & $+\sigma$ & - & - & - & $\begin{array}{lll} & \diamond\end{array}$ & $\sigma$ & $-r$ & -- \\
\hline 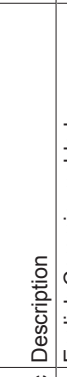 & 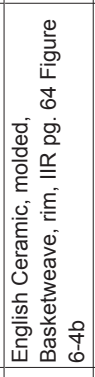 & 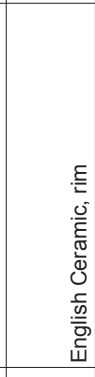 & 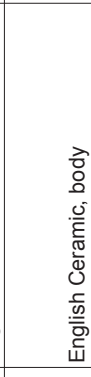 & 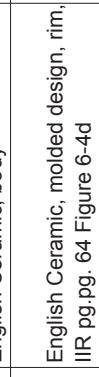 & 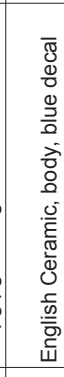 & & 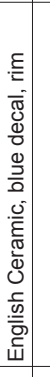 & 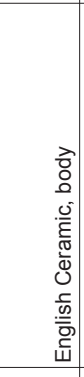 & 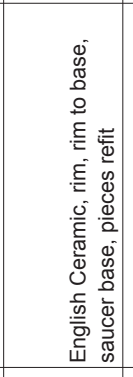 & 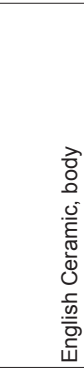 & 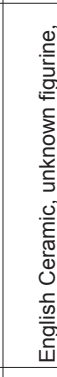 & 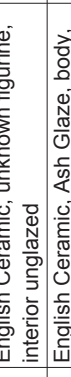 & 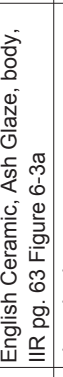 & 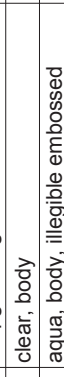 & 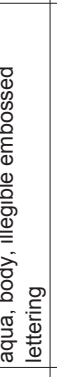 & 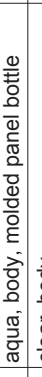 & 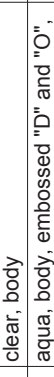 & 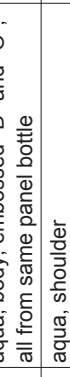 & 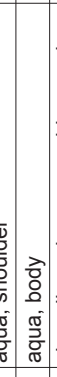 & 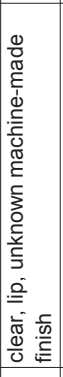 & 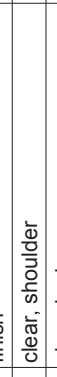 & 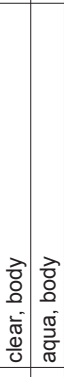 & 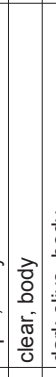 & 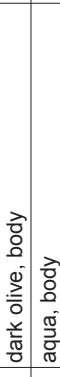 & 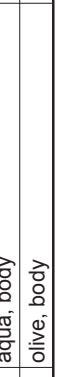 \\
\hline $\begin{array}{l} \\
\end{array}$ & $>$ & $z$ & $z$ & $>$ & $>$ & & $>$ & $z$ & $z$ & $z$ & & $>$ & $z$ & $z$ & $>$ & $z=$ & $z$ & $>z$ & $z$ & $z$ & $z$ & $z z$ & $z$ & $z z$ & $z z$ \\
\hline 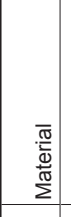 & 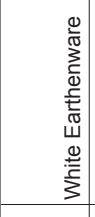 & 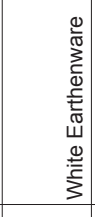 & 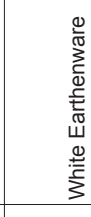 & 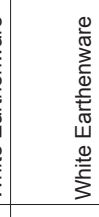 & 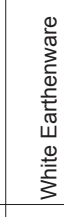 & & 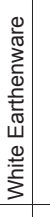 & 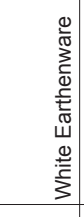 & 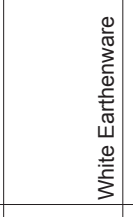 & 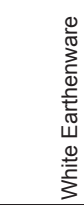 & & 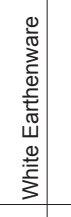 & 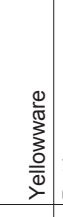 & 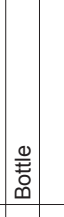 & 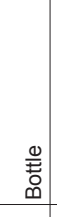 & 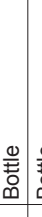 & 童 & 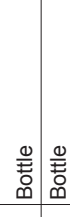 & $\begin{array}{c} \\
\end{array}$ & & 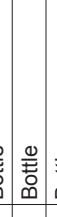 & 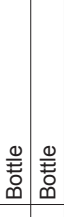 & 竧 & 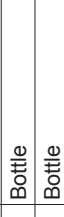 & $\begin{array}{l}\text { 兽 } \\
\end{array}$ \\
\hline $\begin{array}{l}\overline{\mathrm{g}} \\
\mathrm{w} \\
\mathrm{g} \\
\mathrm{d} \\
\end{array}$ & 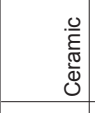 & 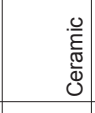 & .ֶ. & 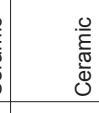 & .ֶ. & & 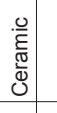 & 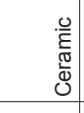 & $\begin{array}{l}0 \\
\stackrel{0}{\tilde{E}} \\
\frac{\tilde{w}}{\tilde{U}} \\
0\end{array}$ & 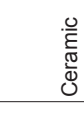 & & $\begin{array}{l}0 \\
\bar{E} \\
\overline{\tilde{E}} \\
\mathcal{U} \\
0\end{array}$ & 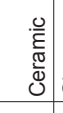 & 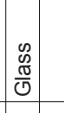 & $\begin{array}{l}\mathscr{D} \\
\mathbb{E} \\
\mathbb{0} \\
\end{array}$ & $y$ & 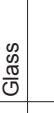 & 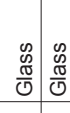 & 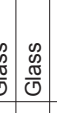 & $\begin{array}{l}\mathscr{D} \\
\frac{\mathbb{d}}{0} \\
\end{array}$ & 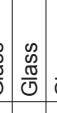 & 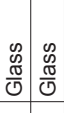 & $\begin{array}{l}\mathscr{y} \\
\frac{1}{0} \\
0\end{array}$ & 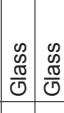 & 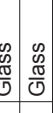 \\
\hline 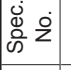 & ธิ & $\overline{8}$ & \% & ธิ & $\stackrel{8}{\circ}$ & & ८ & & $\bar{\delta}$ & & & & & & & & & $\bar{\delta}$ & š & & & & & & \\
\hline \begin{tabular}{|l|l} 
\\
$\frac{\pi}{0}$ \\
\end{tabular} & \begin{tabular}{l} 
o. \\
\hdashline \\
\end{tabular} & $\overline{\mathrm{o}}$ & $\overline{\mathrm{o}}$ & $\stackrel{\text { og }}{\circ}$ & $\stackrel{\text { o. }}{\circ}$ & & 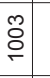 & $\overline{\text { s. }}$ & $\bar{\circ}$ & $\overline{\check{o}}$ & & ô & $\bar{\delta}$ & | & $\begin{array}{l}\text { ơ } \\
\text { N̦ }\end{array}$ & 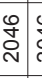 & 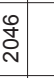 & 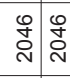 & \begin{tabular}{|l|l}
0 \\
\multirow{2}{*}{}
\end{tabular} & ồ & 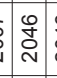 & 竎 & 荇 & \begin{tabular}{l|l}
0 \\
cें \\
aे
\end{tabular} & 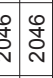 \\
\hline$\frac{\pi}{2}$ & 0 & 0 & U & U & ن & & 0 & 0 & 0 & O & & 0 & $\mathscr{0}$ & ठ & 3 & उ) & త্ & 03 & 30 & $\mathbb{0}$ & bी & త] & త & \begin{tabular}{|l|l|l|} 
\\
0
\end{tabular} & $\begin{array}{ll}50 \\
\end{array}$ \\
\hline 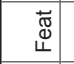 & & & & & & & & & & $\infty$ & & & & & & 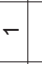 & & & & & & & & & \\
\hline 总 & - & $N$ & N & $\sim$ & $N$ & & $N$ & $m$ & $\nabla$ & $\nabla$ & & $r$ & $\sim$ & 0 & 0 & - & & -- & - & $\sim$ & N & $-r$ & $\sim$ & $-\sim$ & $\sim \sim$ \\
\hline 5 & บี & แี & บี & Щี & แี & & แี & แّ & แี & 广̃ & & $\bar{\amalg}$ & $\bar{\amalg}$ & 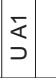 & $\stackrel{\Sigma}{5}$ & 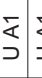 & $\bar{s}$ & $\stackrel{\square}{J}$ & 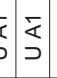 & $\stackrel{\nwarrow}{J}$ & 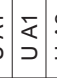 & $\underset{\coprod}{\supset}$ & 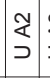 & \begin{tabular}{l|l}
0 \\
0 \\
0
\end{tabular} & $\begin{array}{l}0 \\
0 \\
\end{array}$ \\
\hline $\overrightarrow{\mathrm{s}}$ & $\stackrel{\circ}{\circ}$ & $\stackrel{N}{F}$ & $\stackrel{N}{\stackrel{N}{*}}$ & $\stackrel{N}{F}$ & $\stackrel{N}{ }$ & & $\stackrel{N}{\Gamma}$ & $\stackrel{g}{\rightleftharpoons}$ & $\stackrel{0}{\rightleftharpoons}$ & 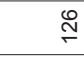 & & $\stackrel{\text { Oे }}{\circ}$ & & 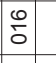 & $\frac{0}{0}$ & ¿ิ & $\bar{\delta}$ & $\bar{\delta} \bar{\delta}$ & $\overline{\bar{\delta}} \bar{\delta}$ & & $\mathbb{J}$ & 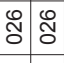 & 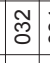 & 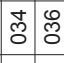 & $\begin{array}{ll}0 \\
3 \\
3\end{array}$ \\
\hline $\begin{array}{c}0 \\
2 \\
0 \\
\frac{0}{3} \\
\frac{0}{\pi \frac{\pi}{0}} \\
0 \\
0\end{array}$ & 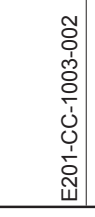 & $\begin{array}{l}\overline{0} \\
\vdots \\
\overline{0} \\
\dot{j} \\
\dot{u} \\
\tilde{u} \\
\tilde{w} \\
\end{array}$ & 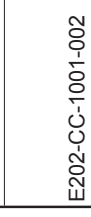 & 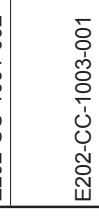 & 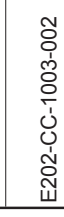 & & 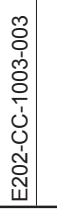 & $\begin{array}{l}\bar{\delta} \\
\bar{d} \\
\dot{u} \\
\dot{\omega} \\
\tilde{w} \\
\end{array}$ & 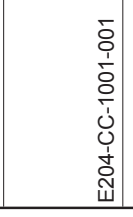 & 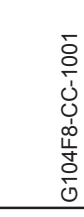 & & 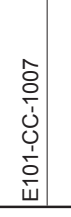 & 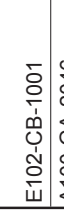 & 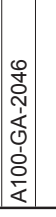 & 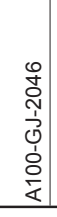 & 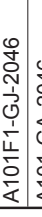 & & 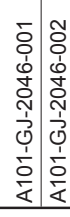 & 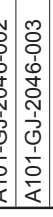 & 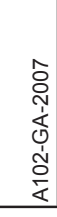 & 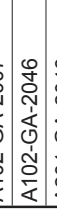 & 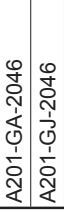 & $\mid$ & 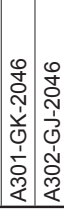 & 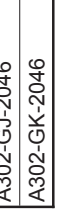 \\
\hline
\end{tabular}









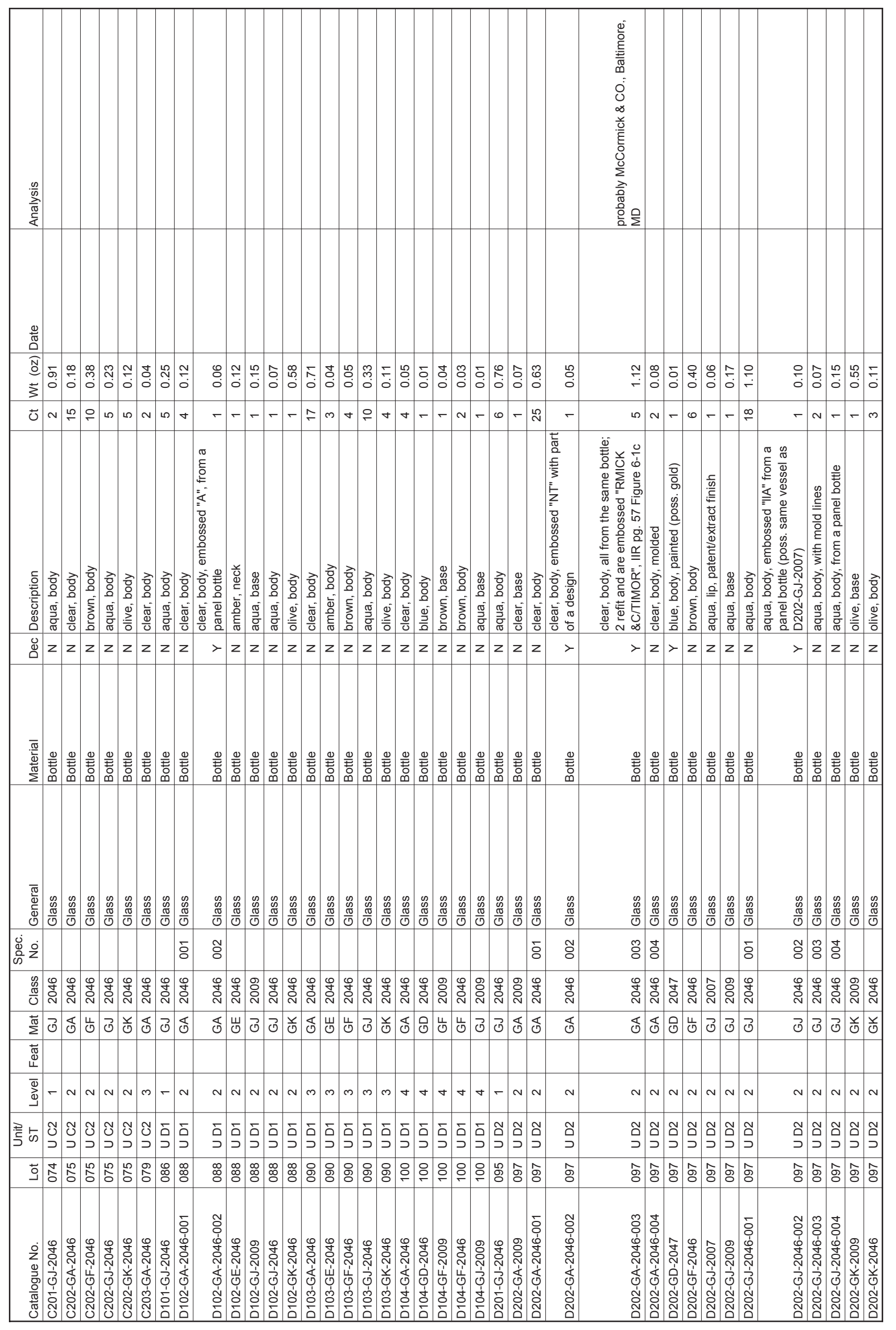




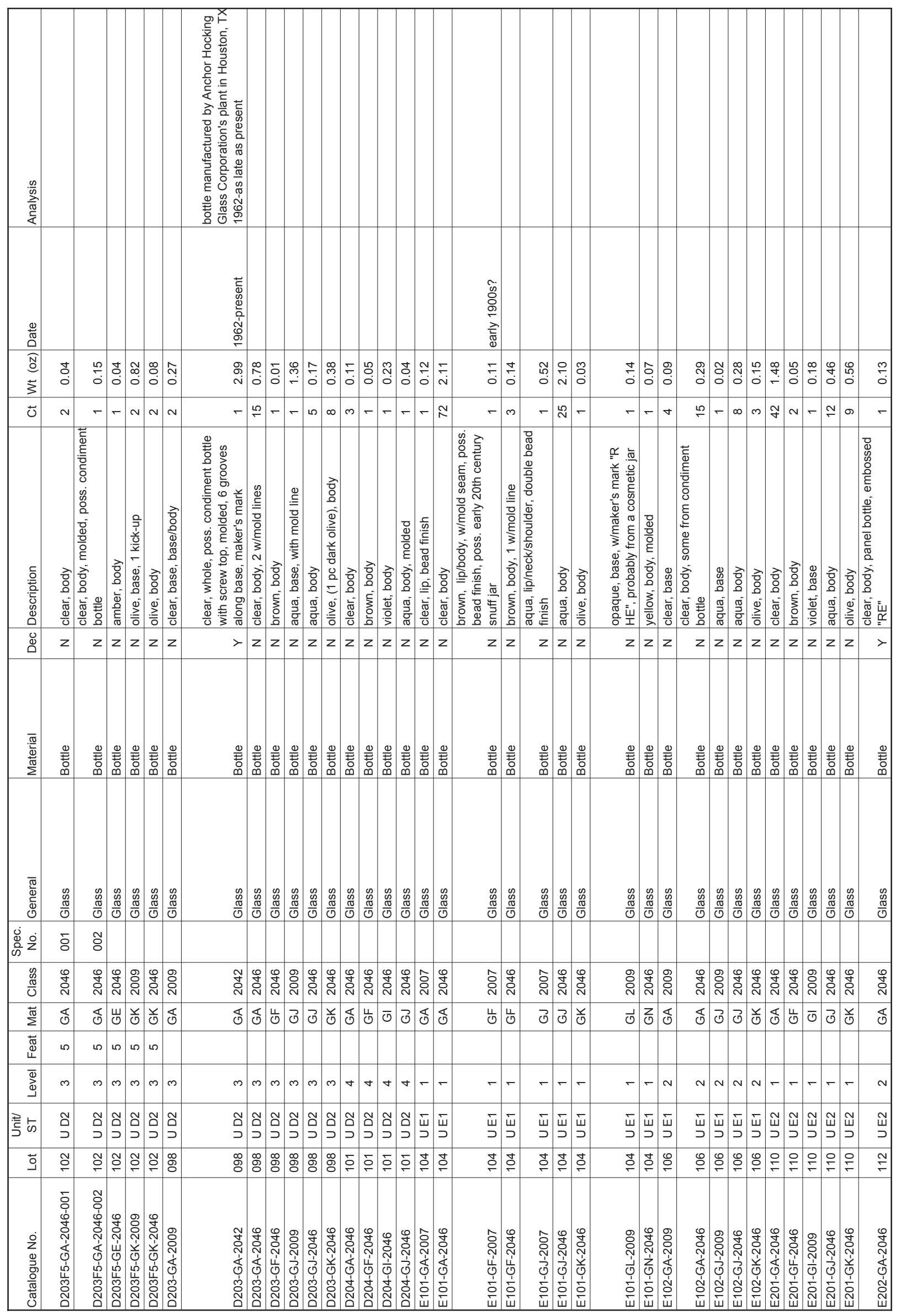




\begin{tabular}{|c|c|c|c|c|c|c|c|c|c|c|c|c|c|c|c|c|c|c|c|c|c|c|c|c|}
\hline 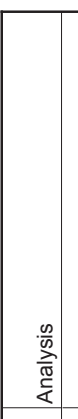 & & 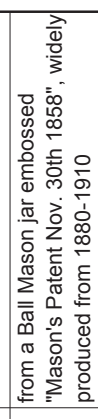 & & & & & & & & & & & & & 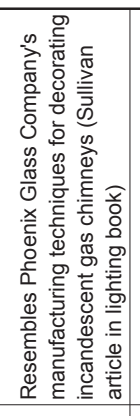 & 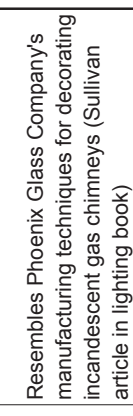 & & & & 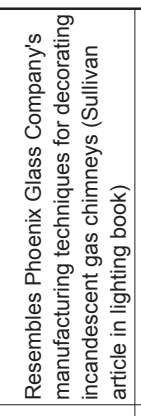 & & & & \\
\hline $\begin{array}{l}\frac{9}{\pi} \\
\text { वे }\end{array}$ & & 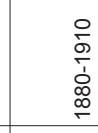 & & & & & & & & & & & & & 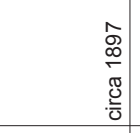 & 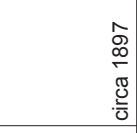 & & & & 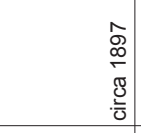 & & & & \\
\hline \begin{tabular}{l}
$\widehat{\widehat{N}}$ \\
\multirow{3}{3}{}
\end{tabular} & 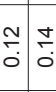 & o. & 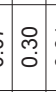 & $\begin{array}{l}\tilde{O} \\
\dot{0}\end{array}$ & & do & & o: & 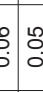 & $\tilde{c}$ & \begin{tabular}{c} 
\\
\hdashline
\end{tabular} & 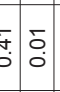 & & $\tilde{b}_{5}^{5}$ & $\stackrel{\circ}{\circ}$ & $\stackrel{8}{\circ}$ & $\begin{array}{l}b_{0} \\
\dot{s} \\
\\
0\end{array}$ & $\begin{array}{ll} \\
\\
0\end{array}$ & $\begin{array}{c}\hat{m} \\
0 \\
0\end{array}$ & $\bar{\delta}$ & {$\left[\begin{array}{c}0 \\
0 \\
0 \\
0\end{array}\right.$} & & $\dot{b}$ & $\begin{array}{l}\tilde{c} \\
\vdots \\
\vdots\end{array}$ \\
\hline$\overline{0}$ & $-\sim$ & - & $-\sim$ & - & - & - & - & -5 & - & 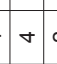 & N- & -- & N- & $-\stackrel{\circ}{\circ}$ & $\checkmark$ & - & $\sim$ & $-\sigma$ & $\stackrel{20}{2}$ & - & $\sim$ & $m-$ & - & $-m$ \\
\hline 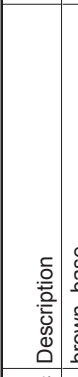 & 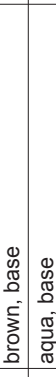 & 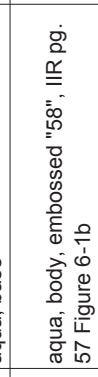 & 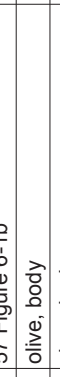 & 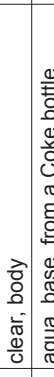 & 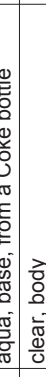 & 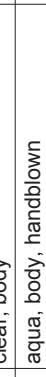 & 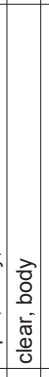 & 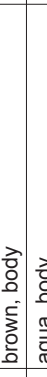 & 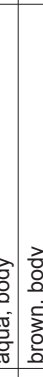 & 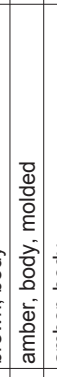 & 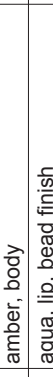 & 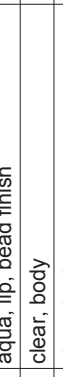 & 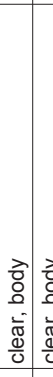 & 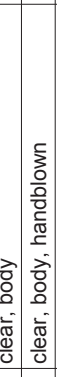 & 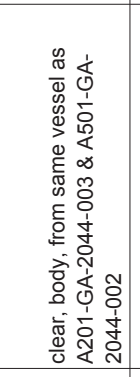 & 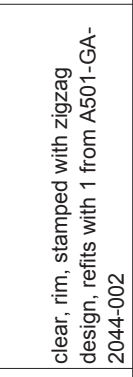 & 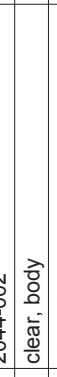 & 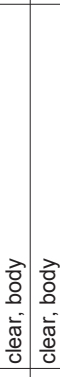 & 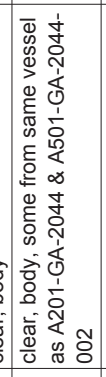 & 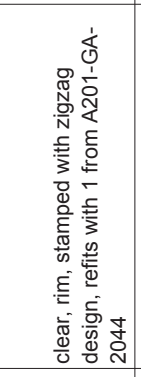 & 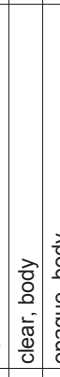 & & 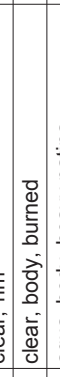 & 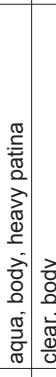 \\
\hline$\stackrel{0}{a}=$ & $z z$ & $>$ & $z$ & $z z$ & $z z$ & $z$ & $z$ & $z z$ & $z z$ & $z$ & $z z$ & $z z$ & $z z$ & $z z$ & $z$ & $>$ & $z$ & $z z$ & $z$ & $>$ & z z & & $z$ & $z z$ \\
\hline 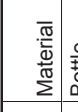 & & 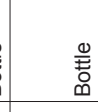 & 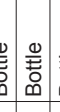 & 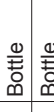 & 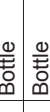 & 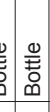 & 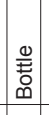 & 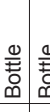 & & 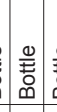 & 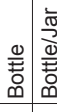 & 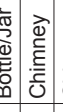 & 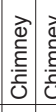 & 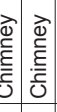 & $\begin{array}{l}\overrightarrow{\mathrm{d}} \\
\stackrel{\vec{\xi}}{\bar{\partial}} \\
0\end{array}$ & $\begin{array}{l}\text { बे } \\
\stackrel{\underline{E}}{E} \\
\end{array}$ & 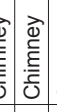 & 离 & $\begin{array}{l}\overrightarrow{\mathrm{d}} \\
\underline{\underline{\epsilon}} \\
\text { U. } \\
\end{array}$ & $\begin{array}{l}\vec{d} \\
\stackrel{\vec{\epsilon}}{\bar{t}} \\
\vec{U}\end{array}$ & $\left(\begin{array}{l}\vec{d} \\
\bar{e} \\
\bar{e} \\
\bar{c}\end{array}\right.$ & & 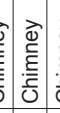 & 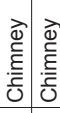 \\
\hline 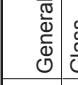 & 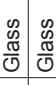 & 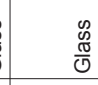 & 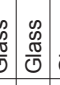 & 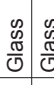 & 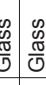 & 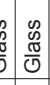 & $\begin{array}{l}\mathscr{W} \\
\frac{\pi}{0} \\
\end{array}$ & 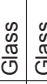 & 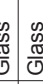 & 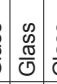 & 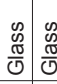 & 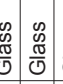 & 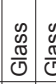 & 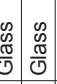 & $\begin{array}{c}\mathscr{0} \\
\frac{\mathbb{d}}{0}\end{array}$ & $\begin{array}{l}\mathscr{0} \\
\frac{\mathscr{0}}{0} \\
\end{array}$ & 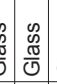 & 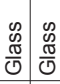 & $\begin{array}{l}\mathscr{D} \\
\mathbb{w} \\
0\end{array}$ & $\begin{array}{l}\mathscr{w} \\
\frac{\mathbb{d}}{\mathbb{N}}\end{array}$ & $\begin{array}{l}\mathscr{w} \\
\tilde{w} \\
\frac{\sigma}{\sigma}\end{array}$ & & 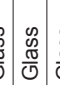 & $\begin{array}{l}\mathscr{w} \\
\bar{c} \\
\mathcal{T}\end{array}$ \\
\hline 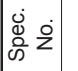 & & & & & & & & & & & & & & $\overline{8}$ & ธิ & ஜ & & & $\bar{s}$ & ธั & & & $\tilde{8}$ & \\
\hline $\begin{array}{cl}0 & 0 \\
0 \\
0\end{array}$ & : & 옴 & \begin{tabular}{l}
0 \\
\multirow{2}{*}{}
\end{tabular} & \begin{tabular}{l|l} 
cơ \\
cे
\end{tabular} & 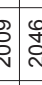 & 宵起 & 㛄 & 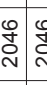 & \begin{tabular}{l}
0 \\
\multirow{2}{*}{} \\
v
\end{tabular} & ìํ & ڤ̊ํे & ș & 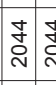 & 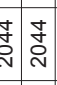 & 芯 & 苾 & ง & 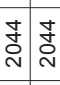 & 芯 & 芩 & वे & & $\vec{d}$ & 龸 \\
\hline$\stackrel{\pi}{\tilde{\pi}}$ & \begin{tabular}{l|l} 
\\
0
\end{tabular} & 3 & $3 \frac{\mathrm{x}}{0}$ & $\begin{array}{lll} & 0 \\
\end{array}$ & $\begin{array}{ll}0.0 \\
\end{array}$ & 3 & $\mathbb{0}$ & $\overline{0} \bar{c}$ & 5 㟢 & Ш & \begin{tabular}{|l|l|l} 
& 0 \\
\end{tabular} & 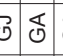 & $\overleftarrow{0}$ & $\begin{array}{l}\mathbb{0} \\
0 \\
\end{array}$ & $\overleftarrow{0}$ & $\mathbb{0}$ & c & త్ర & $\overleftarrow{0}$ & $\widetilde{J}$ & $\mathbb{1}$ & & $\delta_{0}^{\pi}$ & उ తీ \\
\hline $\begin{array}{l}\overline{\widetilde{J}} \\
\mathbb{L} \\
\end{array}$ & & & & & 0 & 0 & & & $\infty$ & & & & & & & & & & & & & & & \\
\hline 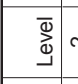 & N & $N$ & $\checkmark N$ & $m$ & $m$ & מ & - & $-\tau$ & $-\sim$ & - & $\begin{array}{cc}N & 0\end{array}$ & 00 & $-\gamma$ & N- & - & $r$ & -2 & N- & $r$ & - & - & & - & -- \\
\hline $\begin{array}{lll} \\
\end{array}$ & แึّ & 픅 & ปิ & 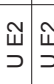 & ํㅣㅎ & ปั & $\begin{array}{l}\overline{0} \\
\partial\end{array}$ & $\begin{array}{ll}\overline{0} \\
\\
\end{array}$ & $\overline{5}$ & $\bar{N}$ & \begin{tabular}{|l|l}
$\bar{N}$ & $\bar{J}$ \\
\end{tabular} & $\bar{s}$ & $\underset{\triangleleft}{J}$ & 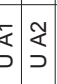 & \} $&{\stackrel{\pi}{J}} &{\frac{1}{2}} &{\text { 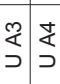 }} &{\text { 选 }} &{\text { 足 }} &{\bar{m}} &{ } &{\text { 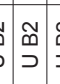 }} &{\text { 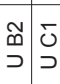 }} \\
{\hline \text { ક }} &{\stackrel{\cong}{\subsetneq} \stackrel{\cong}{\rightleftharpoons}} &{\stackrel{N}{\check{N}}} &{\text { 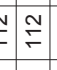 }} &{\stackrel{g}{\mp} \underset{z}{z}} &{\text { 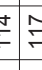 }} &{E \stackrel{F}{F}} &{\stackrel{\stackrel{P}{F}}{\rightleftharpoons}} &{\stackrel{9}{\rightleftharpoons} \stackrel{\circ}{7}} &{\text { 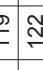 }} &{\overline{-}} &{\stackrel{\substack{\mathfrak{N} \\
0}}{0}} &{5 \div} &{\overline{\tilde{\delta}}} &{\mathbb{Z}} &{\text { 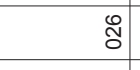 }} &{ } &{\text { sิ }} &{\stackrel{\circ}{\circ} \hat{\varnothing}} &{\text { 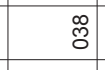 }} &{\begin{array}{l}\infty \\
\hdashline \\
0\end{array}} &{8} &{ } &{\overline{8}} &{\overline{8} \overline{8}} \\
{\hline \text { 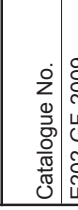 }} &{\text { 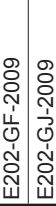 }} &{\text { 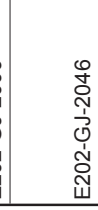 }} &{\text { 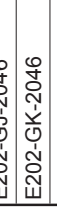 }} &{\text { 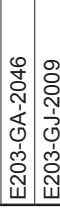 }} &{\text { 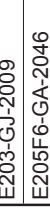 }} &{\begin{array}{l}y_{0} \\
\vdots \\
\vdots \\
\end{array}} &{\text { 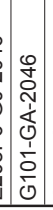 }} &{\text { 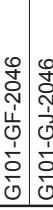 }} &{\text { 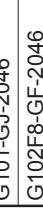 }} &{\text { 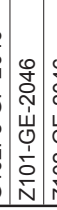 }} &{\text { 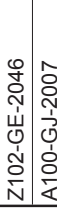 }} &{\text { 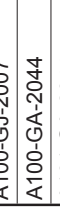 }} &{ } &{\text { 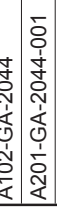 }} &{\text { 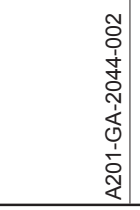 }} &{\text { 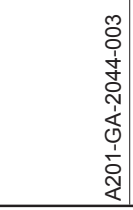 }} &{\text { 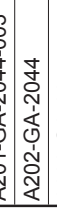 }} &{\text { 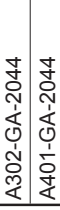 }} &{\text { 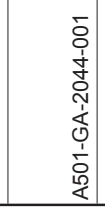 }} &{\text { 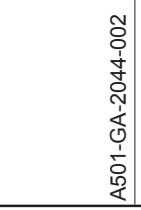 }} &{\text { 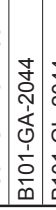 }} &{\text { 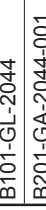 }} &{\text { 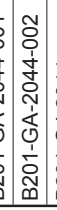 }} &{\text { 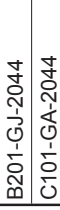 }} \\
$\hline
\end{tabular}




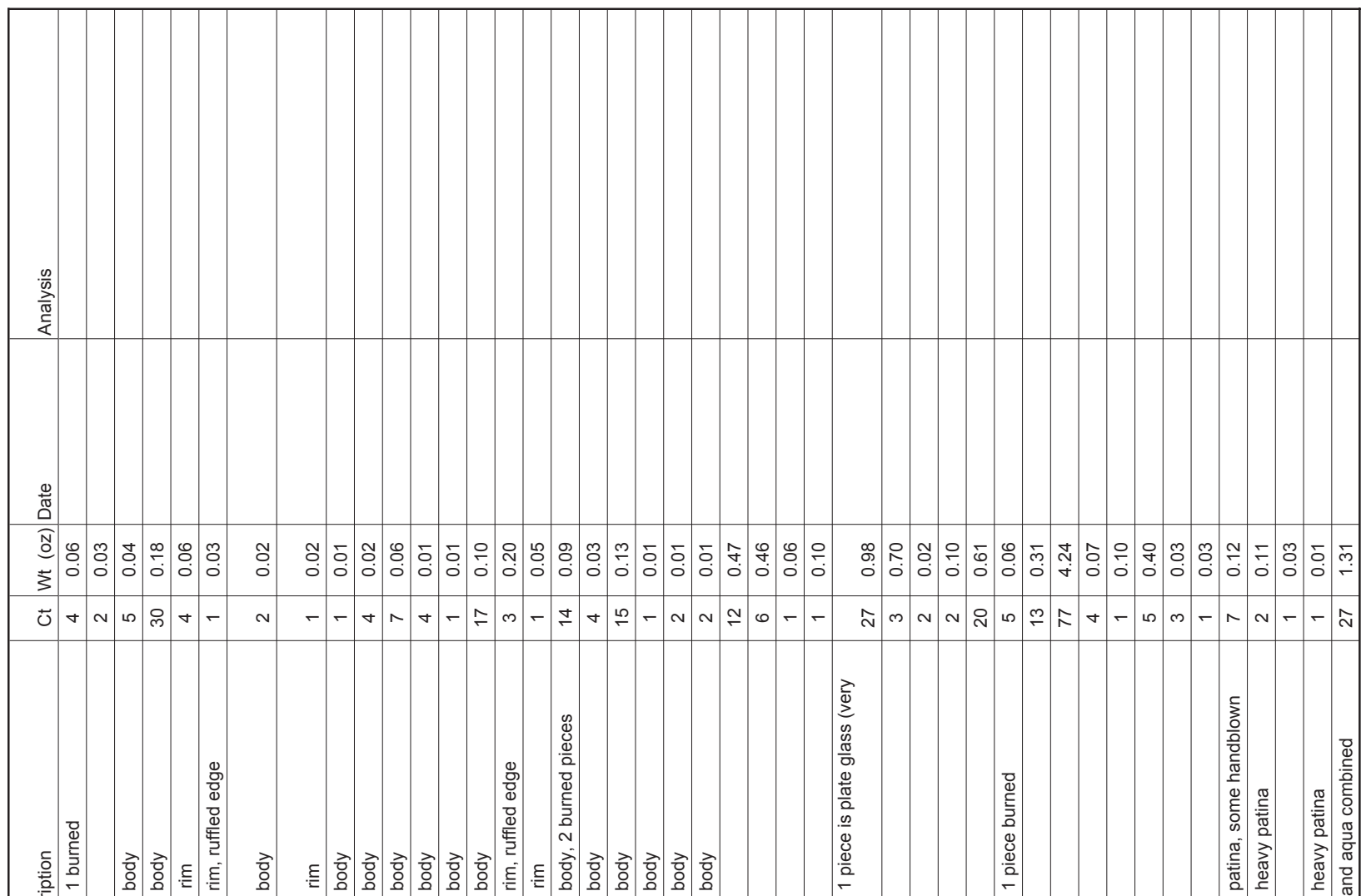

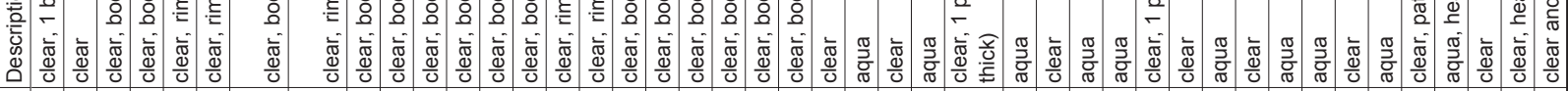

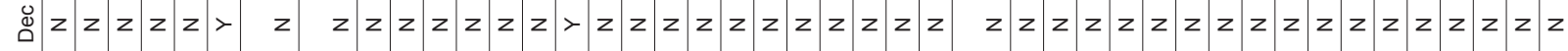

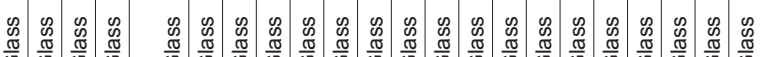

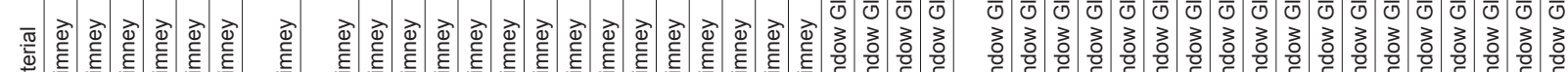

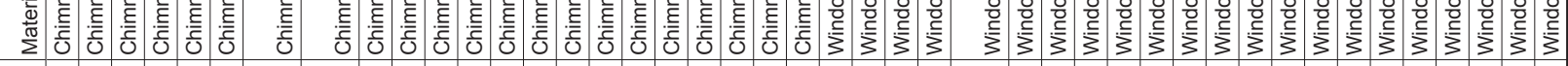

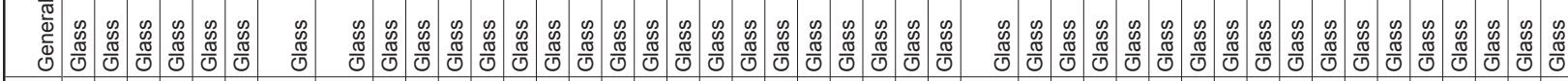

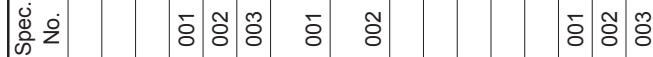

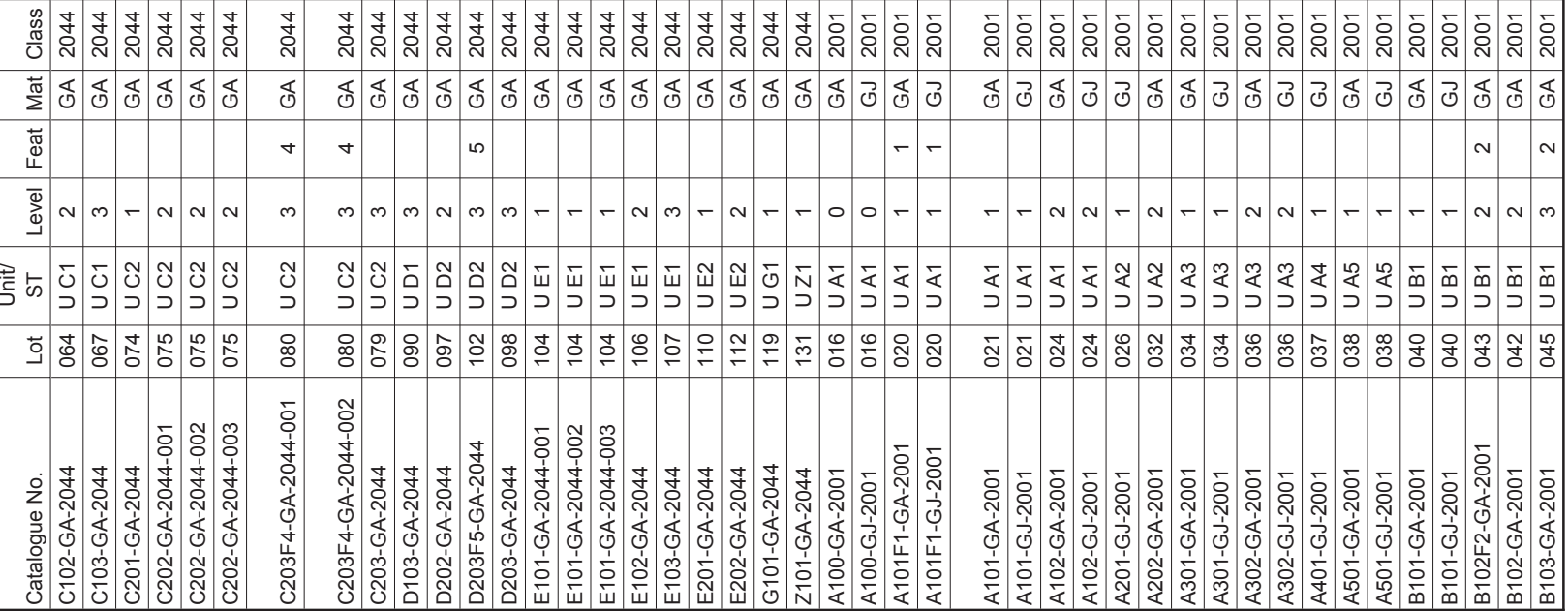




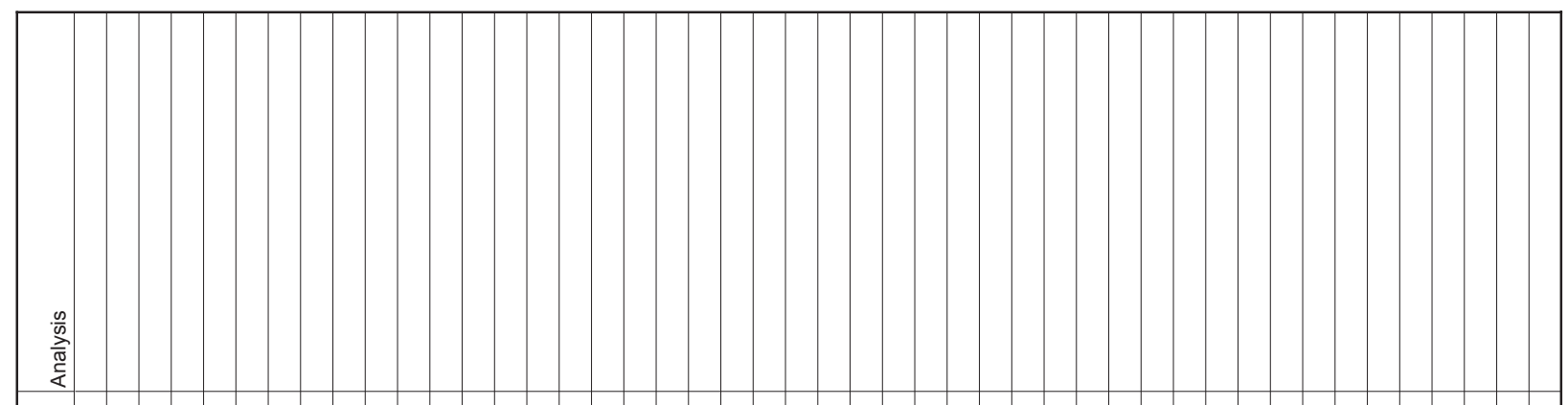

ల̃

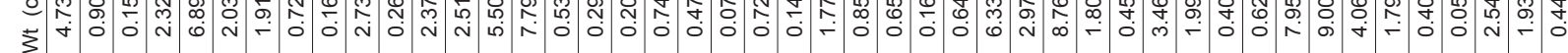
ப兀

흠

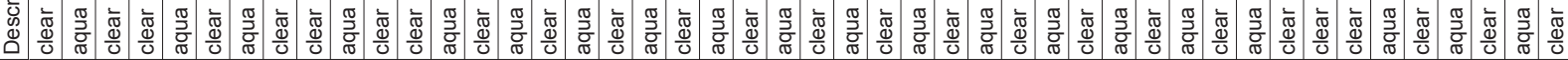

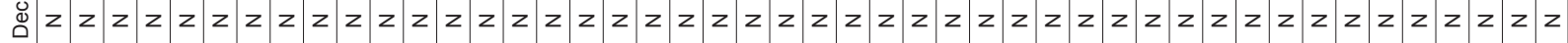

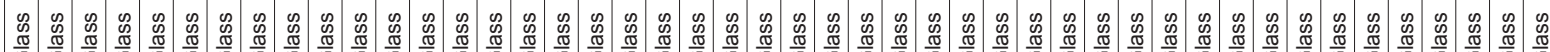

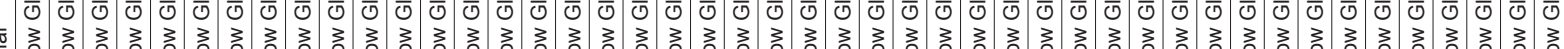

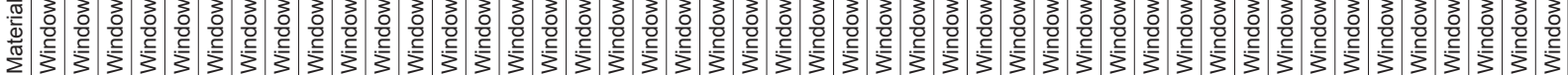

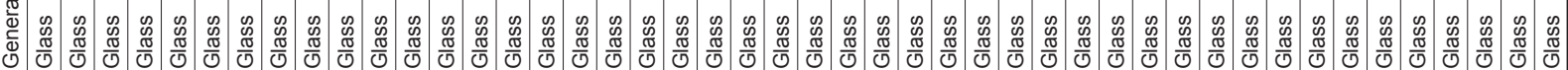
क⿺辶े

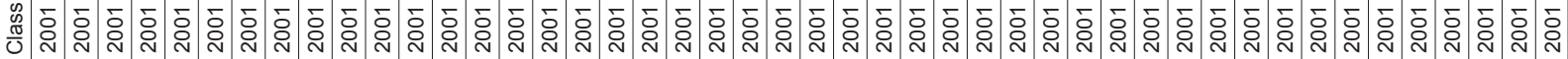

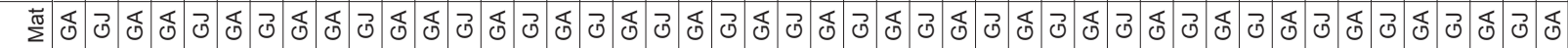

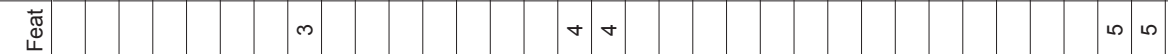

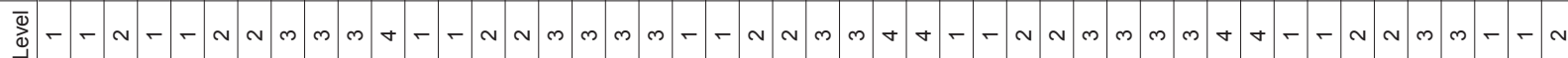

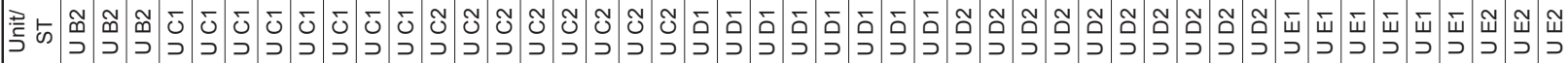

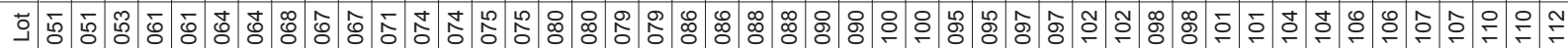

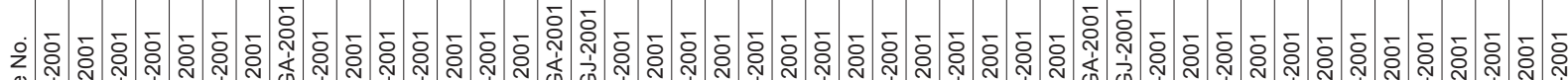

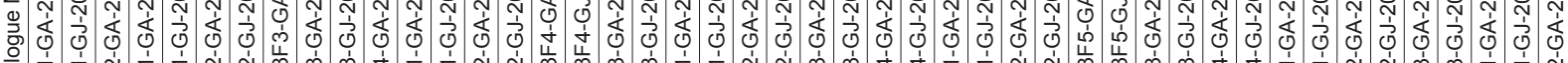

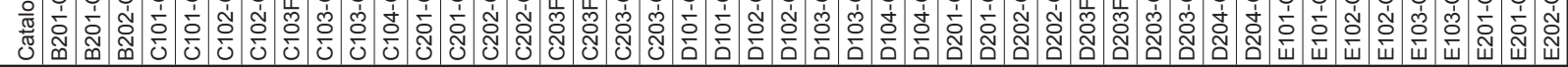




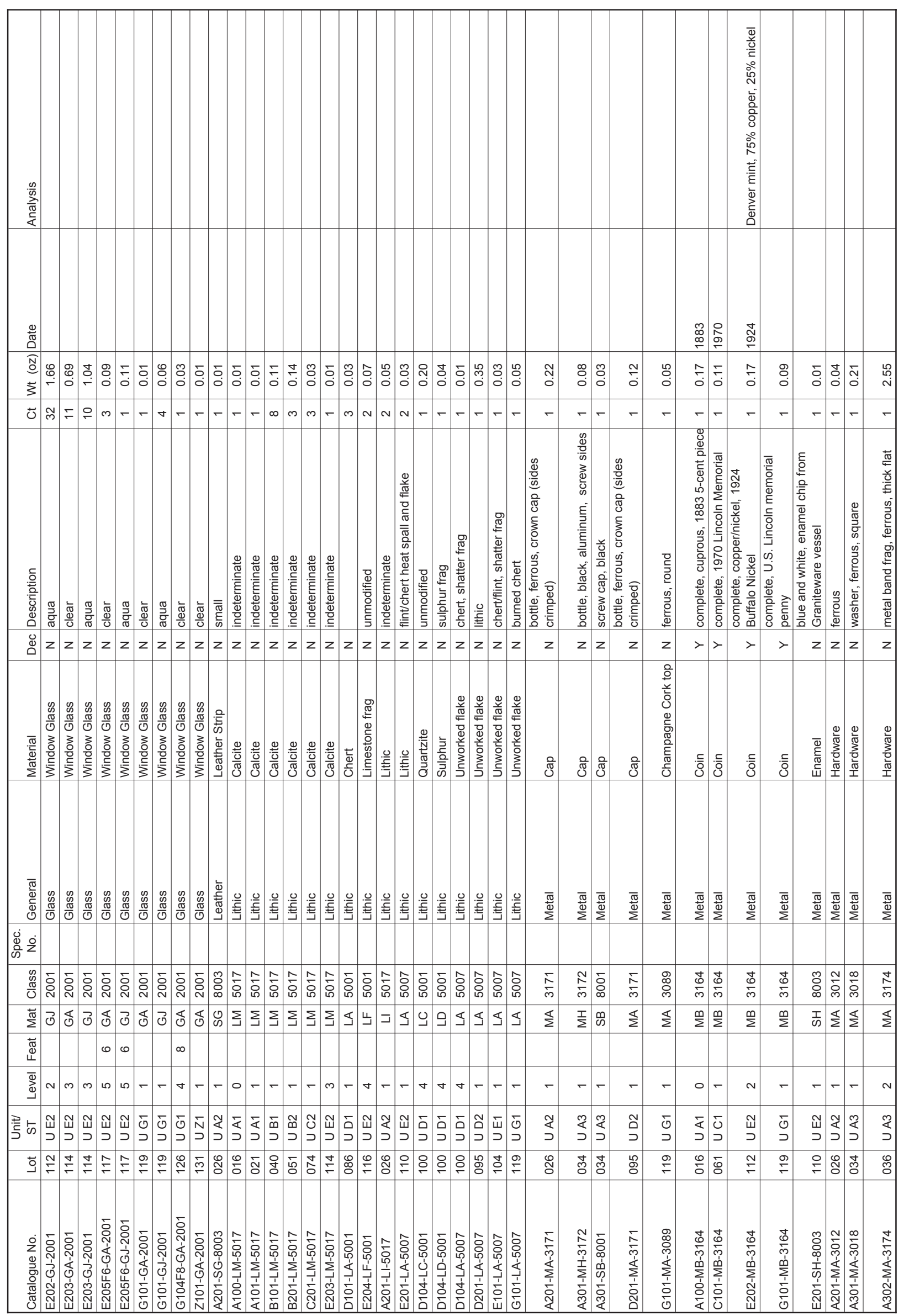




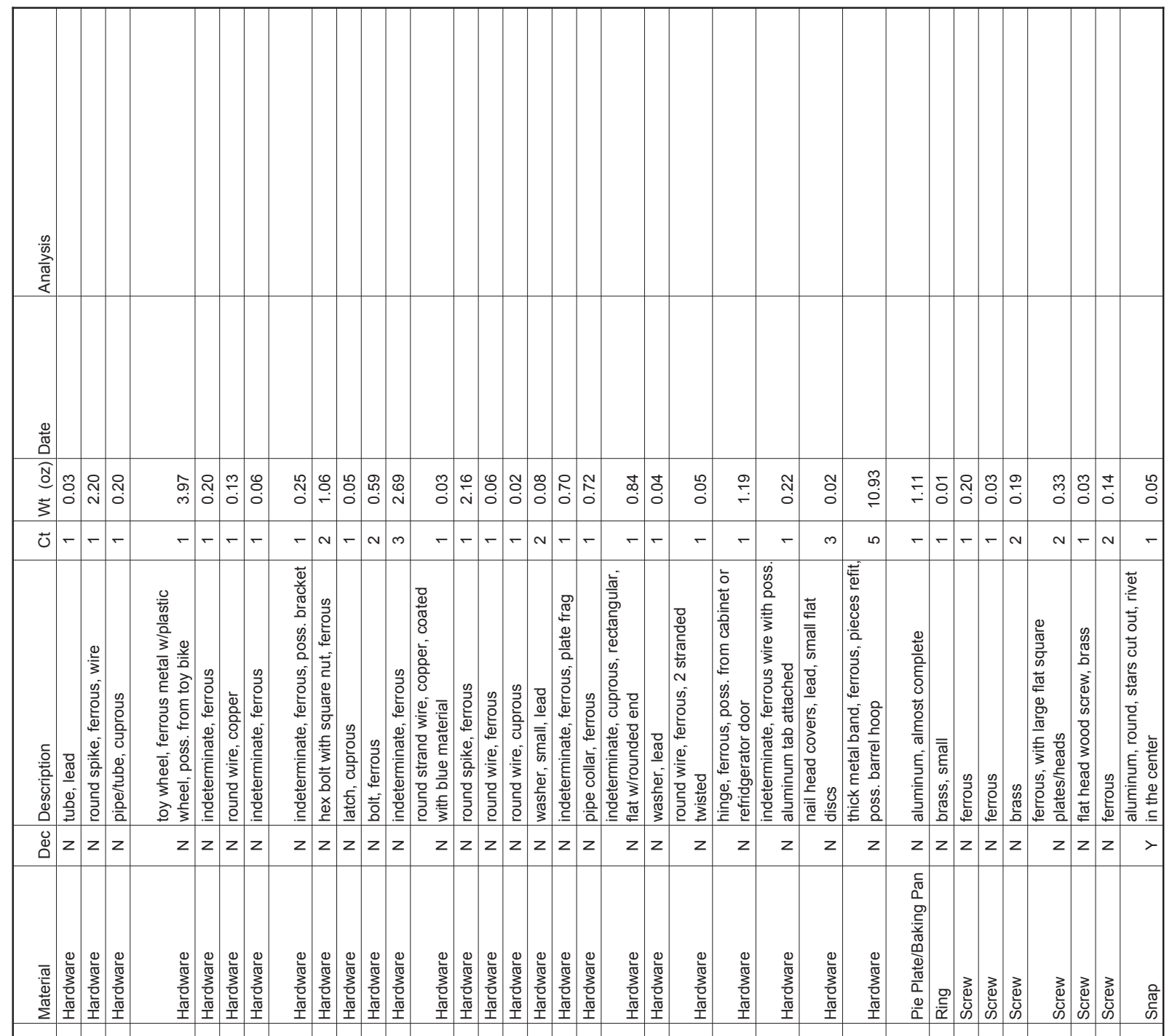

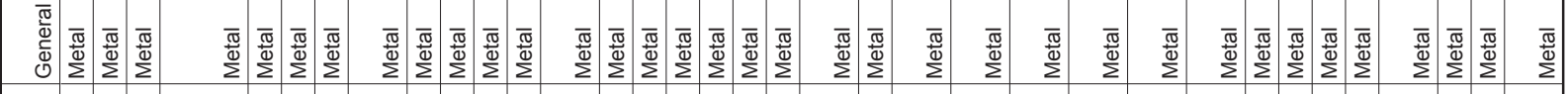
这

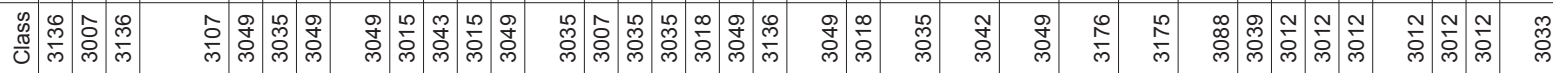

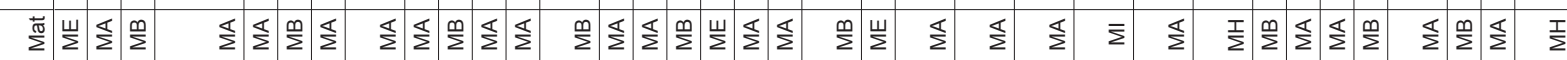
离

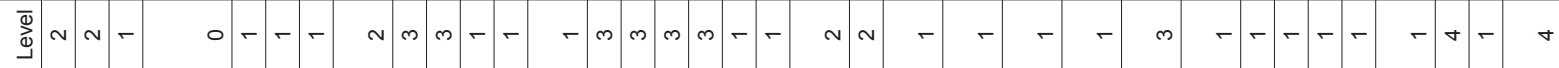

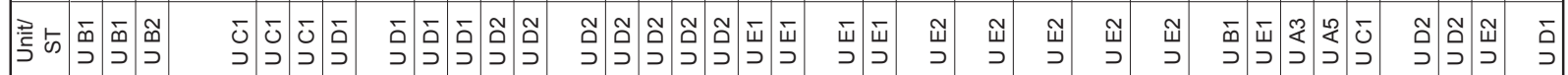

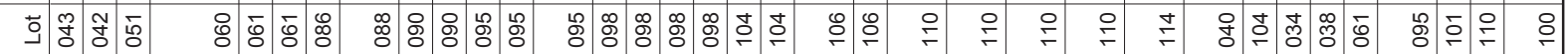

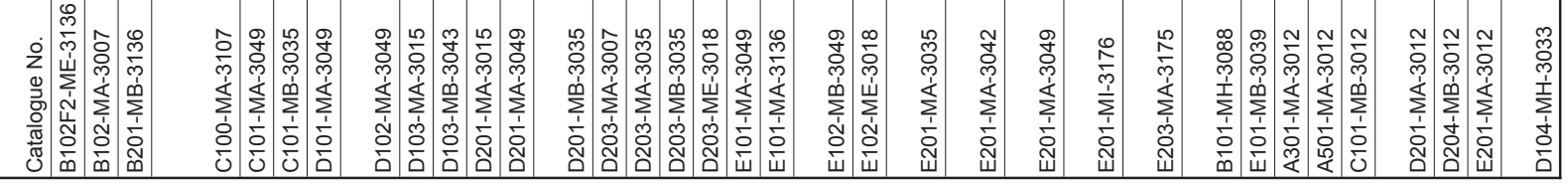




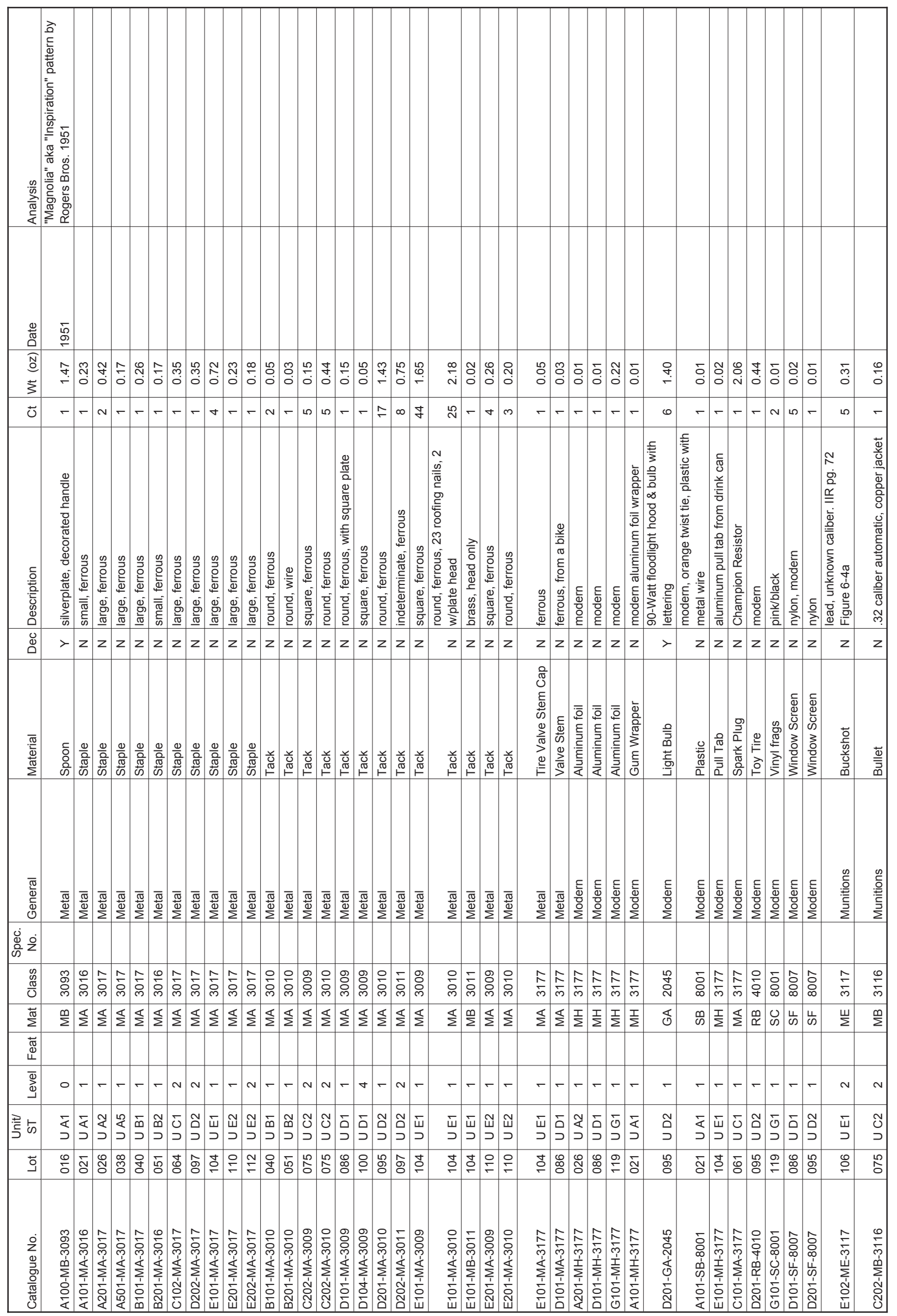




\begin{tabular}{|c|c|c|c|c|c|c|c|c|c|c|c|c|c|c|c|c|c|c|c|c|c|c|c|c|c|c|c|c|c|}
\hline 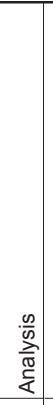 & & 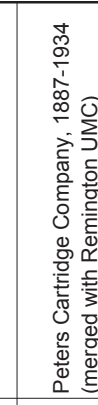 & & & & & & & & & 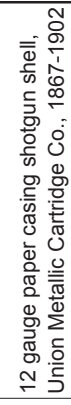 & 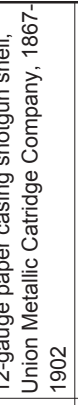 & & 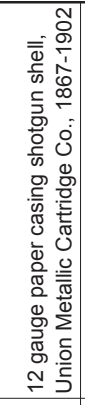 & & & & & & & & & & & & & & & \\
\hline 离 & & 范 & & & & & & & & & 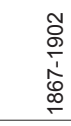 & 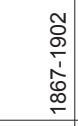 & & 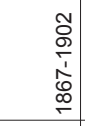 & & & & & & & & & & & & & & & \\
\hline $\begin{array}{l}\widehat{\widehat{v}} \\
\hat{\jmath}\end{array}$ & & $\stackrel{0}{0}$ & $\begin{array}{l}\text { Nิ } \\
0\end{array}$ & $\infty$ & $8 \stackrel{0}{\circ}$ & $\stackrel{1}{0}$ & & $\begin{array}{l}\overline{0} \\
0 \\
0\end{array}$ & $\begin{array}{l}0 \\
0 \\
0\end{array}$ & $\begin{array}{l}\text { to } \\
0 \\
0\end{array}$ & $\stackrel{\text { og }}{0}$ & $\begin{array}{l}0 \\
0 \\
0 \\
\end{array}$ & $\begin{array}{l}\tilde{N} \\
0 \\
0\end{array}$ & $\begin{array}{l}\overline{0} \\
0 \\
\end{array}$ & $\stackrel{q}{\rightarrow}$ & 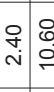 & : & $\stackrel{\odot}{\circ}$ & \begin{tabular}{l|}
8 \\
$\vdots$ \\
$\vdots$
\end{tabular} & 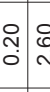 & & & ָి & $\stackrel{8}{\leftarrow}$ & & $\stackrel{m}{0}$ & 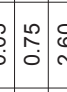 & ৫્ડ & ્ָָ \\
\hline $\mathrm{U}$ & \begin{tabular}{l|l} 
& $\sim$ \\
\end{tabular} & - & - & + & م- & $r$ & $-N$ & - & - & - & $\sim$ & $m$ & - & - & $\mp$ & $\stackrel{m}{\sim} \tilde{g}$ & $\begin{array}{lll}0 & 0\end{array}$ & n & is. & $-I$ & $\begin{array}{l}* \\
N\end{array}$ & - & ส & $\infty$ & $\nabla$ & -- & $-\sigma$ & 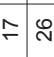 & $\stackrel{c}{\sim}-$ \\
\hline 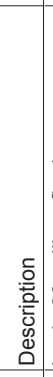 & 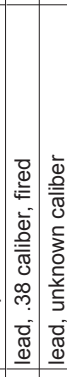 & 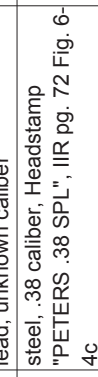 & 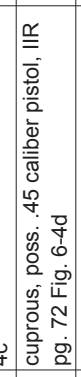 & 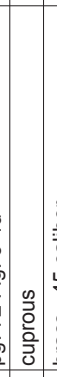 & 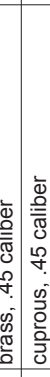 & 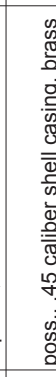 & 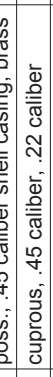 & 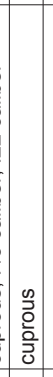 & 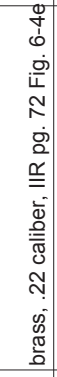 & 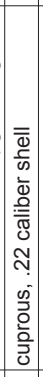 & 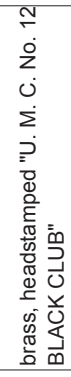 & 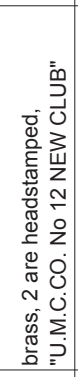 & 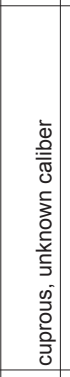 & 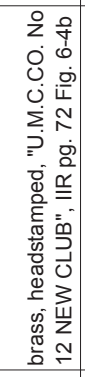 & 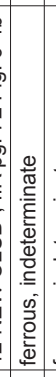 & 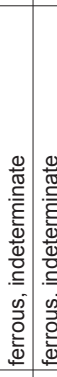 & 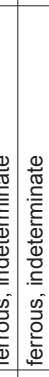 & 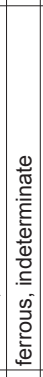 & 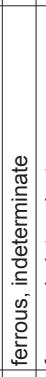 & 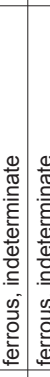 & 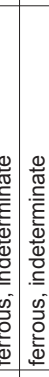 & 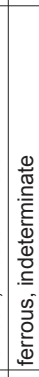 & 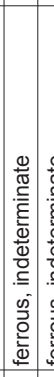 & 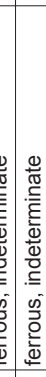 & 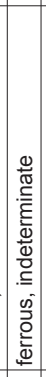 & 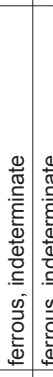 & 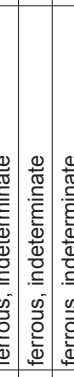 & 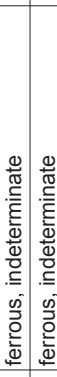 & 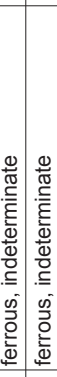 \\
\hline ه্ & $z z$ & $>$ & $z$ & $z$ & $z z$ & $z$ & $z$ & $z$ & $z$ & $z$ & $>$ & $>$ & $z$ & $>$ & $z$ & \begin{tabular}{l|l}
$z$ & $z$
\end{tabular} & $z z$ & z & $z$ & $z z$ & $z z$ & z & $z$ & $z$ & & $z z$ & $z z z$ & $z \mid z$ & \begin{tabular}{l|l}
$z$ & $z$
\end{tabular} \\
\hline$\sum^{\infty}$ & $\frac{\overrightarrow{\underline{\omega}}}{\overline{\bar{\omega}}} \frac{\underline{\underline{\omega}}}{\overline{\underline{\omega}}}$ & 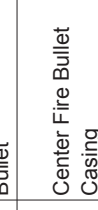 & 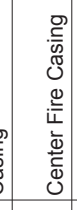 & 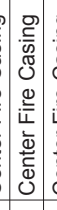 & 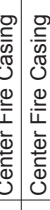 & 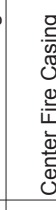 & 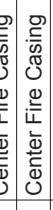 & 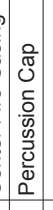 & 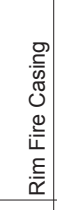 & 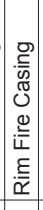 & 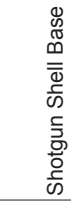 & 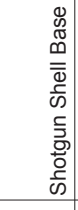 & 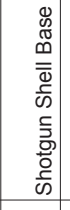 & 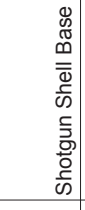 & 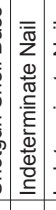 & 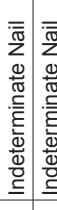 & 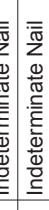 & 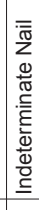 & 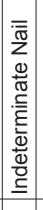 & 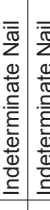 & 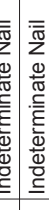 & $\frac{\overline{\bar{\pi}}}{2}$ & 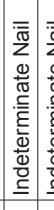 & 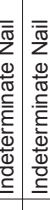 & 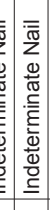 & 点 & 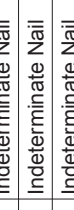 & 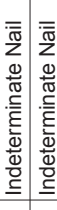 & 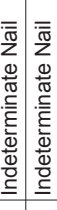 \\
\hline
\end{tabular}

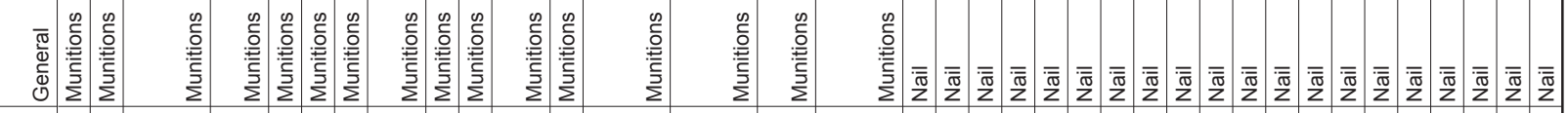
कूँ

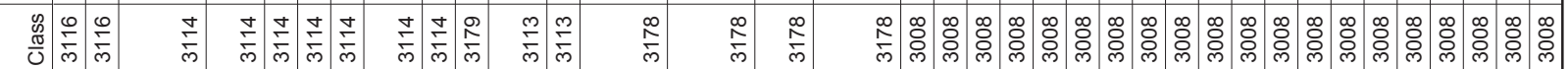

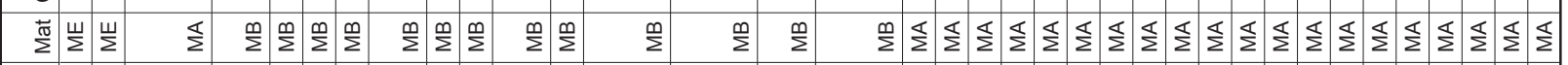

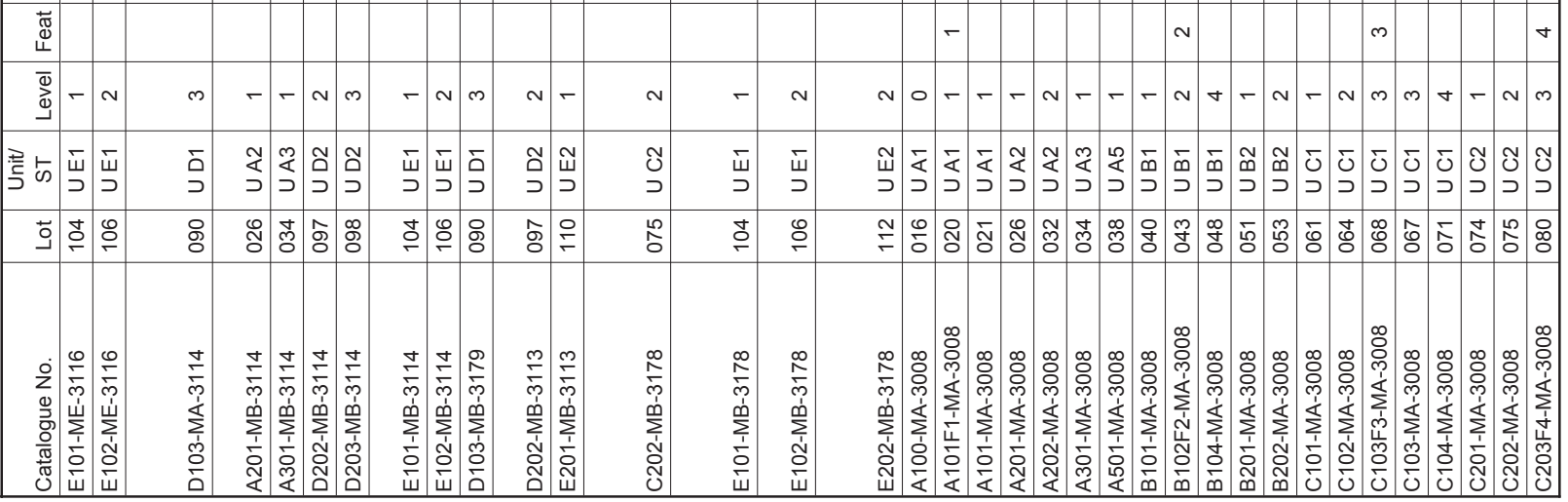




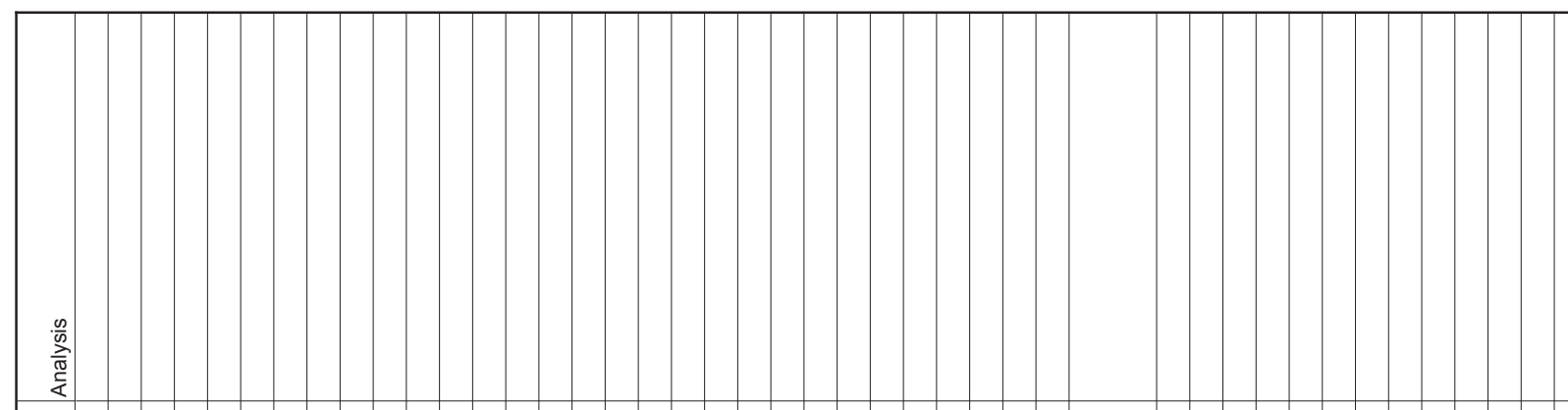

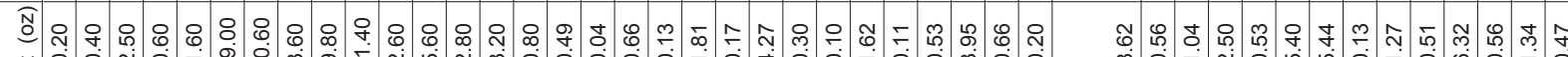

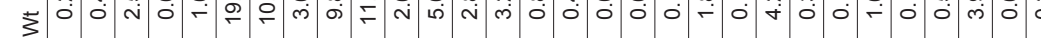

பก ก

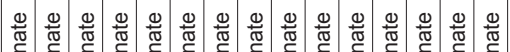

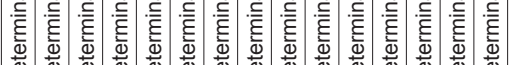
$\infty \frac{\infty}{3}$

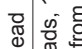

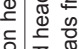

每

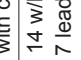

든

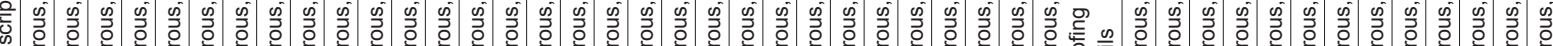

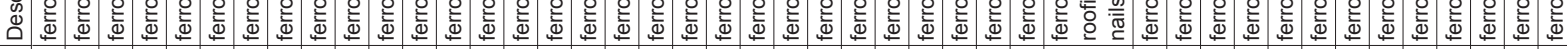

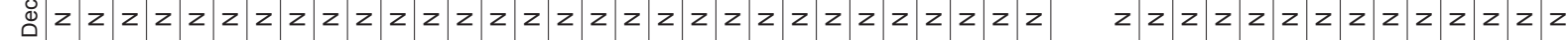

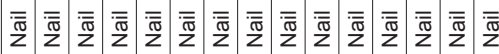

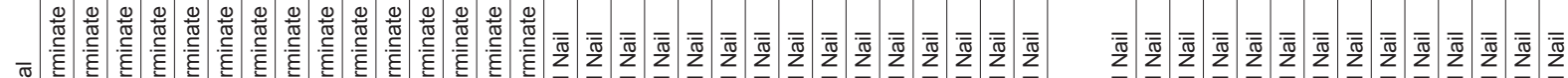

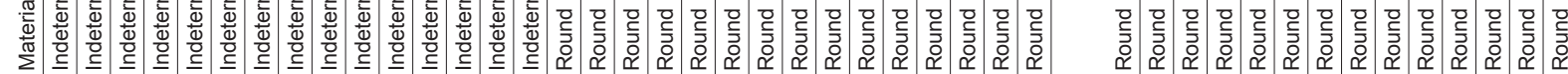
स

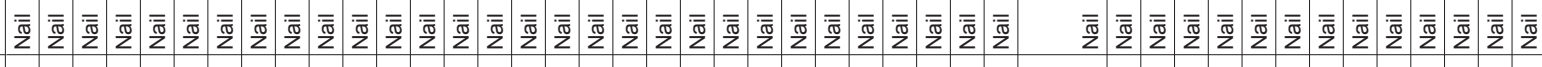
离定

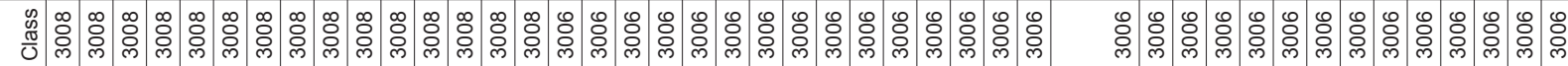

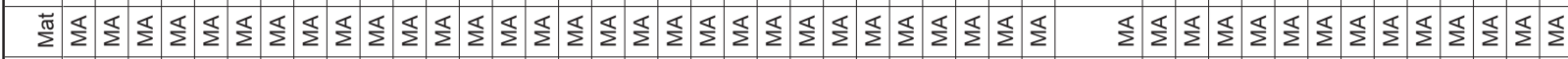
芯

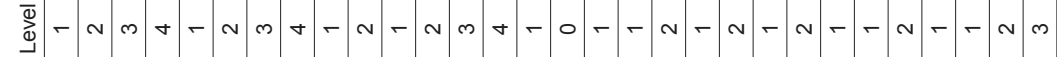

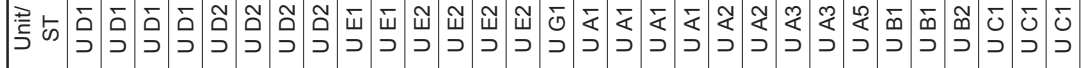

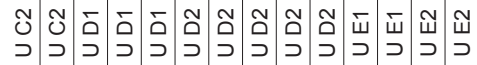

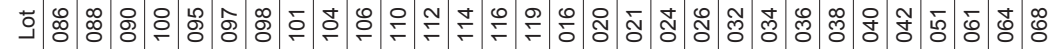

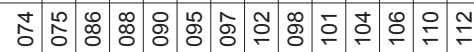
ż

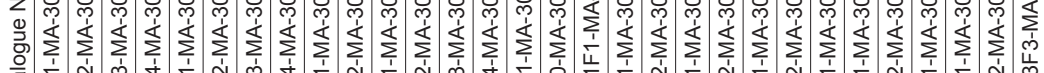

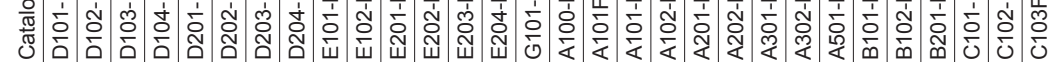
\&:

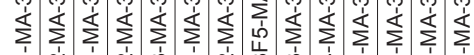

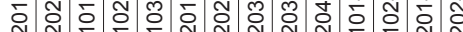




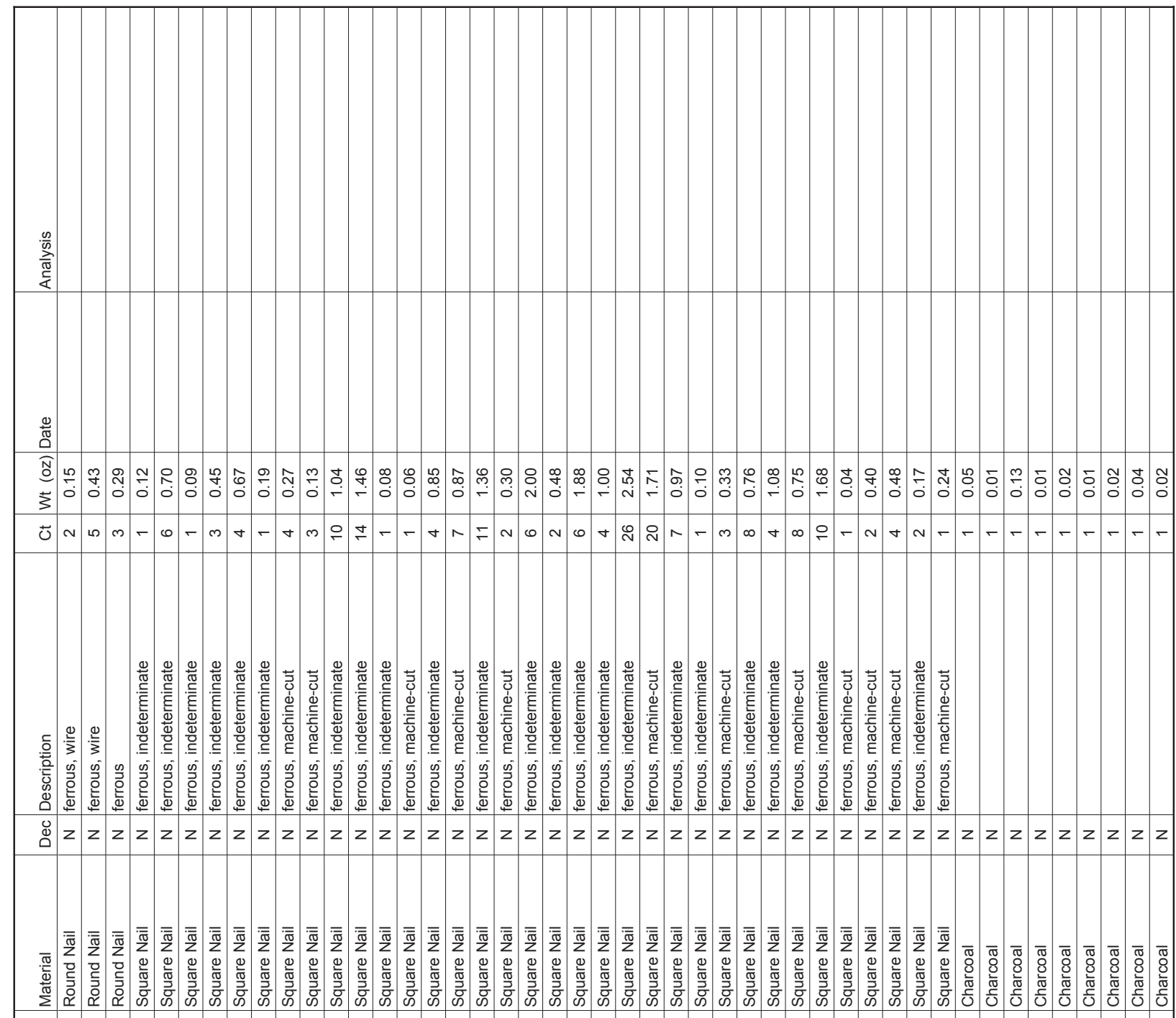

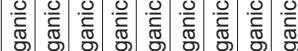
远定

ஜ

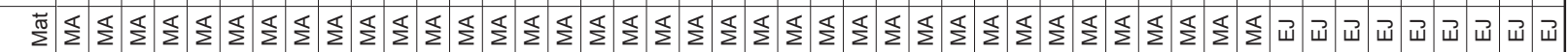

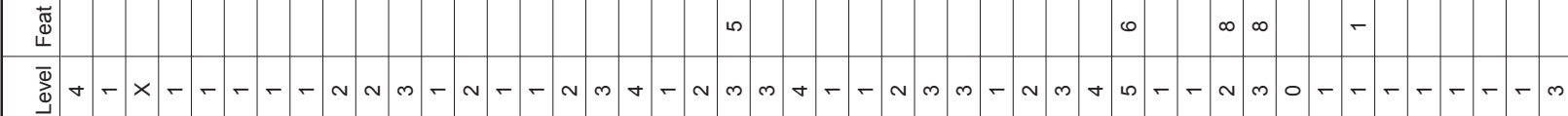

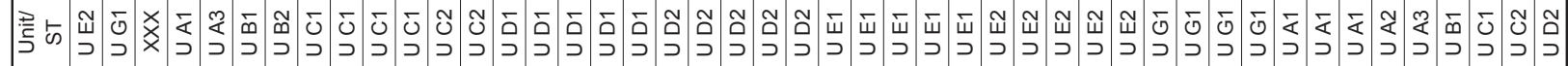

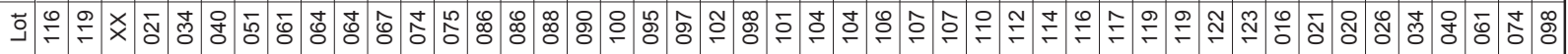
之.

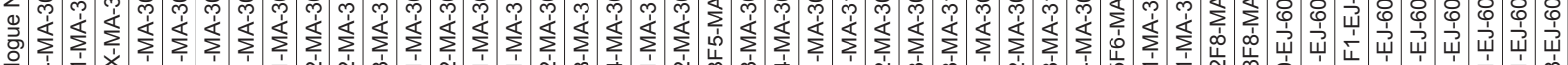

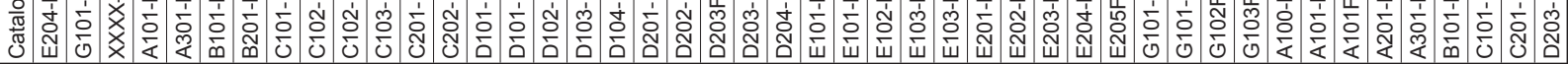




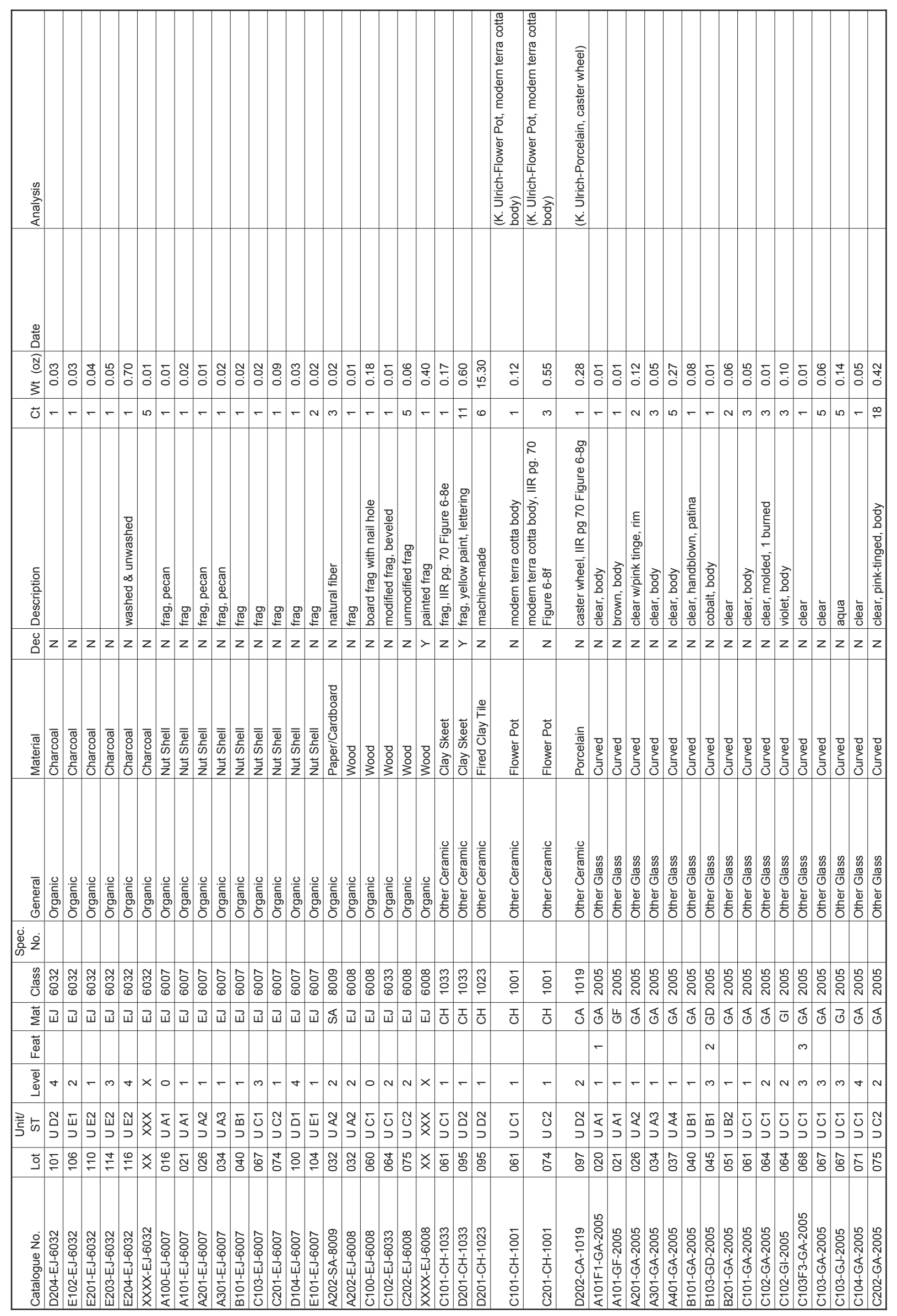




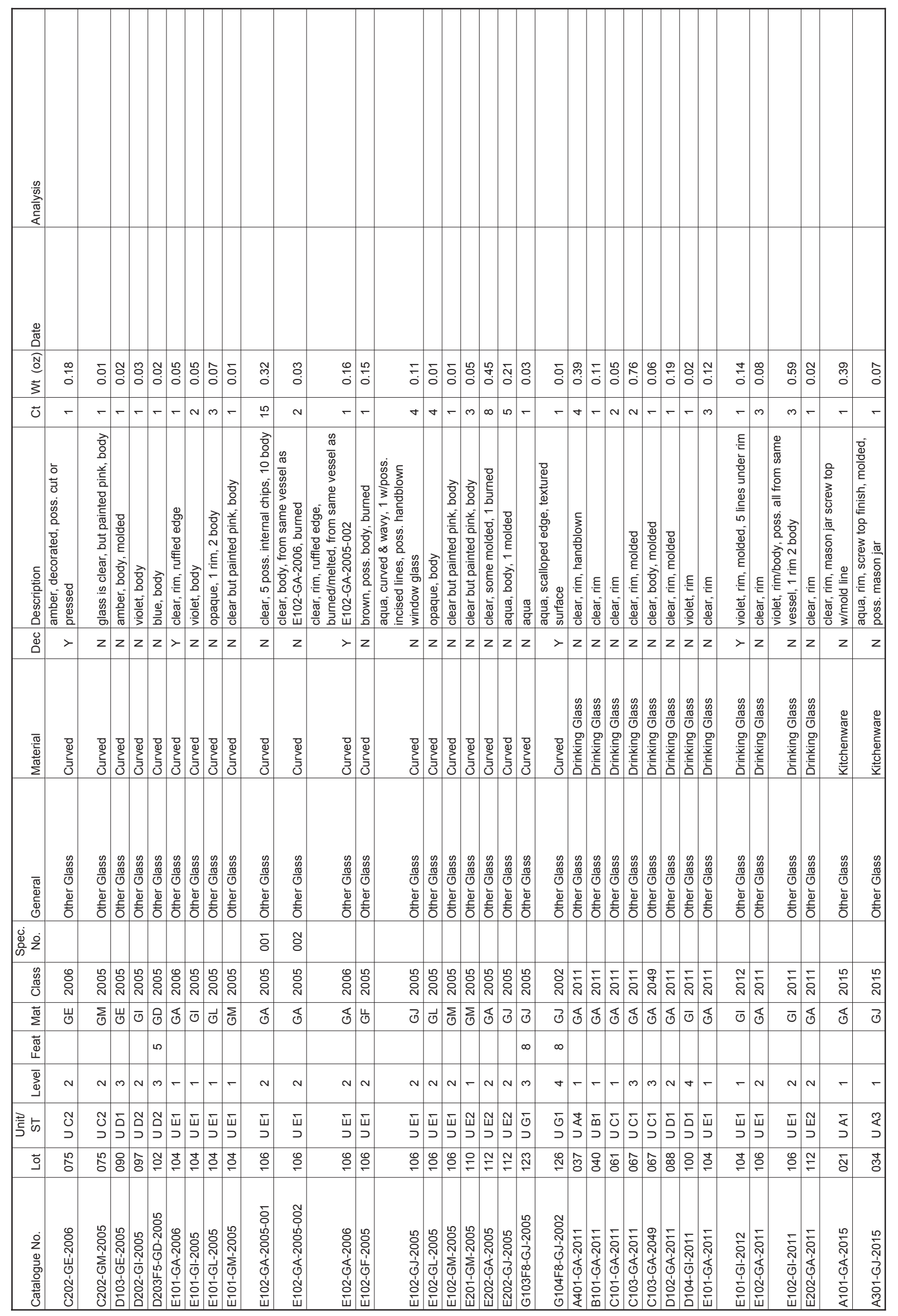




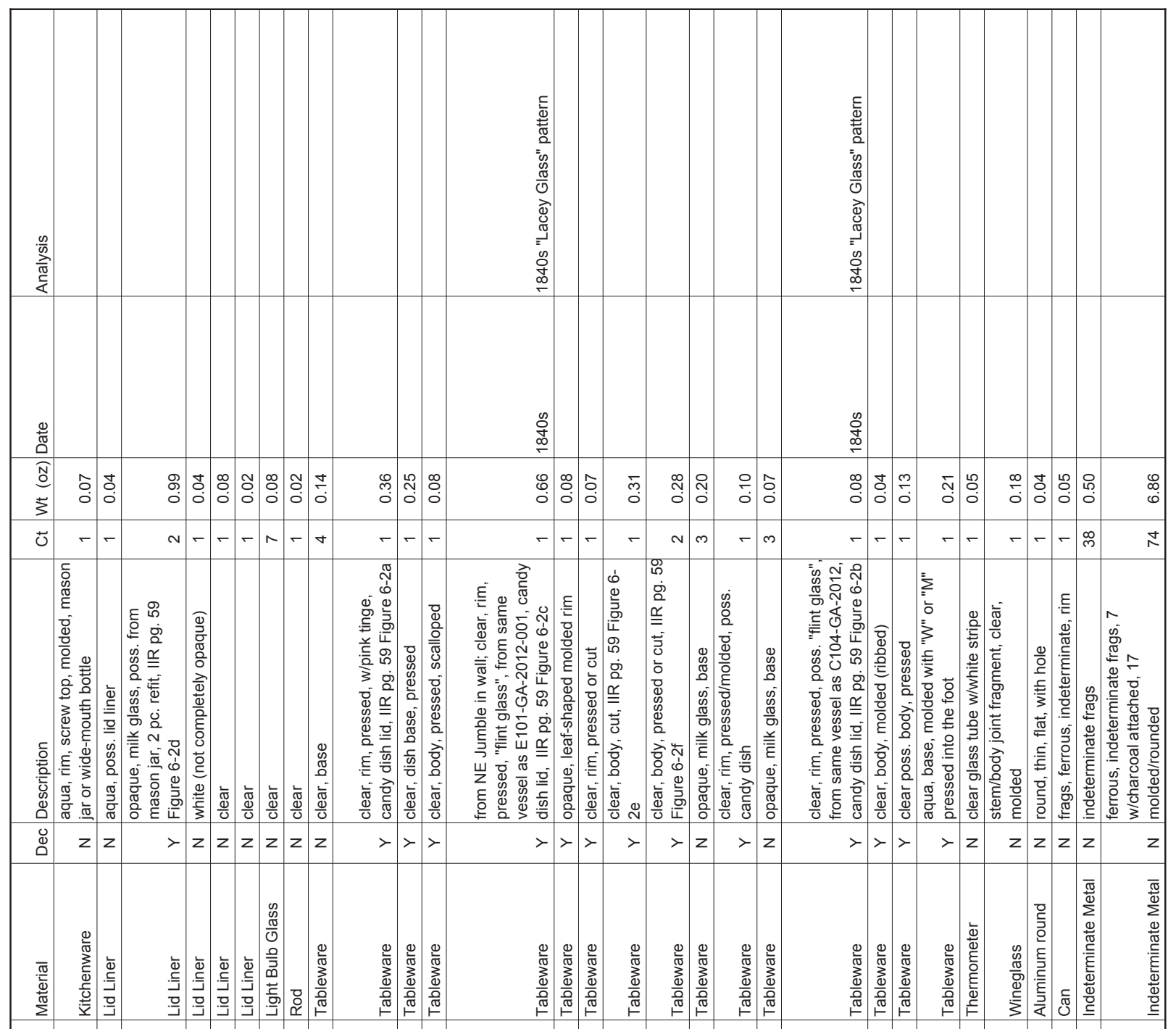

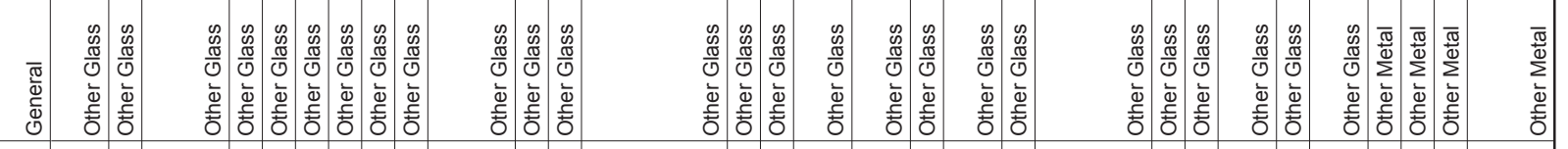
ब⿺辶冋

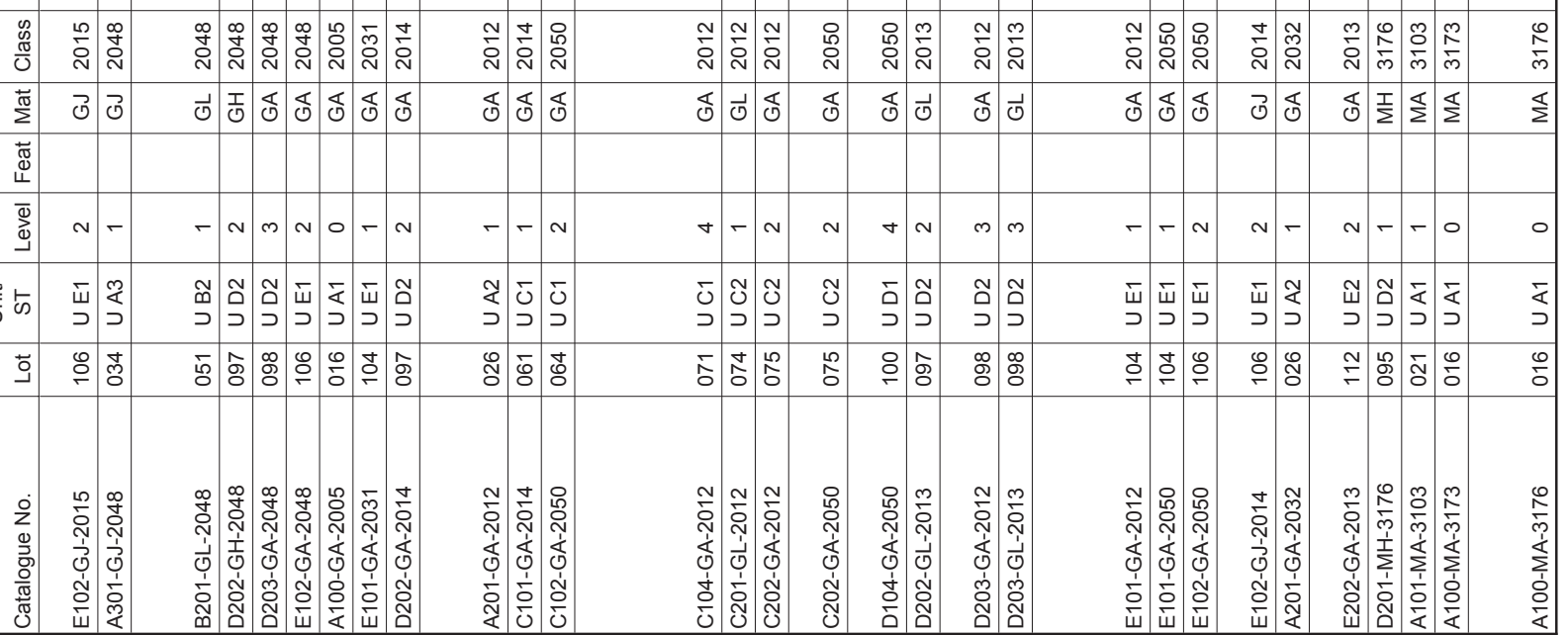




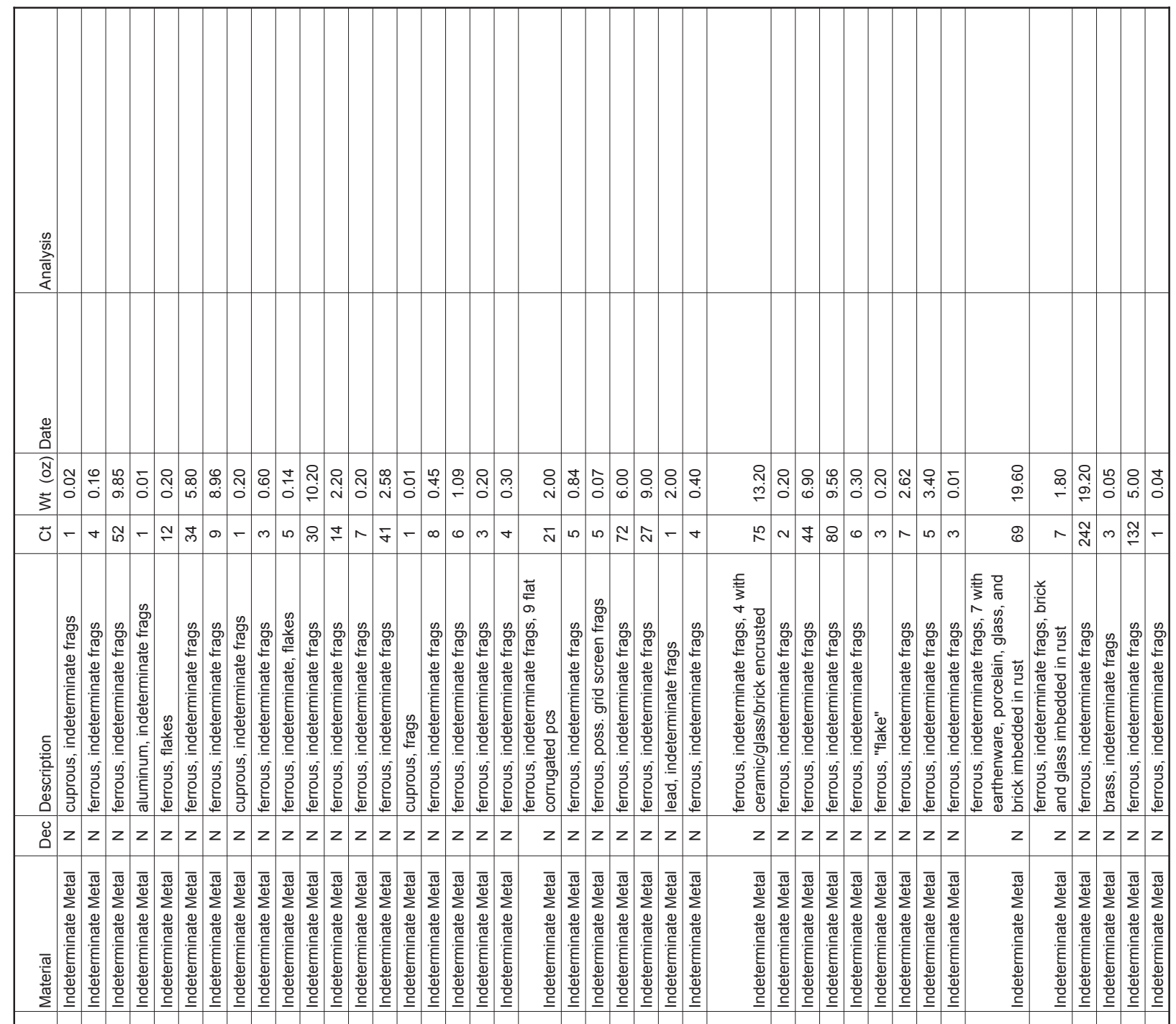

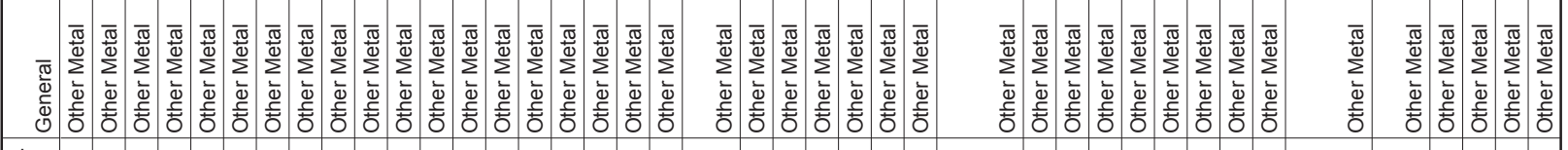
迥

\begin{tabular}{|c|c|c|c|c|c|c|c|c|c|c|c|c|c|c|c|c|c|c|c|c|c|c|c|c|c|c|c|c|c|c|}
\hline 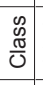 & 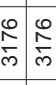 & 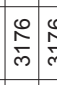 & 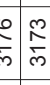 & $\frac{0}{\bar{m}}$ & $\mid \begin{array}{l}0 \\
\frac{0}{m} \\
\vdots \\
\vdots\end{array}$ & & & & & & & & & & $\begin{array}{c}0 \\
0 \\
0 \\
\end{array}$ & & & 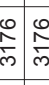 & $\mid \begin{array}{l}0 \\
\frac{0}{m} \\
\end{array}$ & 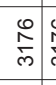 & $\frac{0}{2}$ & & 至 & & & & $\begin{array}{l}0 \\
\stackrel{0}{m}\end{array}$ & $\begin{array}{l}0 \\
\stackrel{0}{m} \\
\end{array}$ & & 童 \\
\hline$\sum^{\pi}$ & $\Sigma \frac{\Sigma}{\Sigma}$ & $\frac{\delta}{\Sigma} \frac{T}{2}$ & $\frac{1}{\Sigma} \sum_{\Sigma}$ & $\frac{5}{\Sigma}$ & $\frac{\delta}{\Sigma}$ & & & & & & & & $\frac{\Sigma}{\Sigma}$ & $\stackrel{\Phi}{\Sigma}$ & $\frac{\mathbb{s}}{\Sigma}$ & & $\frac{\Sigma}{\Sigma}$ & $\Sigma \frac{u}{\Sigma}$ & $\frac{\mathbb{s}}{\Sigma}$ & $\frac{1}{2}$ & $\frac{\pi}{2}$ & & $\frac{\delta}{z}$ & & $\Sigma$ & & $\frac{\mathbb{s}}{\Sigma}$ & $\frac{s}{2}$ & & $\frac{1}{\Sigma}$ \\
\hline 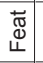 & - & & & & & & & & & & & $v$ & N & & & & & & $m$ & & & & & & & & & م & & \\
\hline & & & $-N$ & & & & 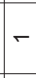 & - & s & & $r$ & $\mathrm{v}$ & $\infty$ & m & - & & - & $\sim$ & 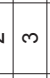 & $m$ & 5 & & - & & 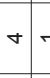 & & $\sim$ & & & \\
\hline & 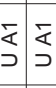 & $\left(\begin{array}{l}\searrow \\
د\end{array}\right.$ & $\begin{array}{l}5 \\
\end{array}$ & $\underset{J}{5}$ & & & & & D & & & & $\stackrel{\bar{m}}{\rho}$ & & $\stackrel{\sim}{\stackrel{m}{\supset}}$ & & J & \begin{tabular}{l|l}
$\bar{\delta}$ & $\overline{0}$ \\
$\bar{\nu}$
\end{tabular} & 5 & & כ) & & $\bar{a}$ & & & & & ป̃ & & \\
\hline ث̊ & 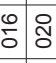 & $\bar{\delta}$ & $\bar{\Xi}$ & 政 & $\mathbb{D}$ & $\ddot{g}$ & 总 & 照 & 品 & f & 8 & $\stackrel{f}{f}$ & $\frac{8}{8}$ & I & $\overline{8}$ & 6 & $\overline{8}$ & : & 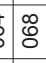 & $\hat{8}$ & 5 & 0 & 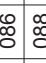 & & 읨 & & à & $\stackrel{\alpha}{\sigma}$ & & \\
\hline $\begin{array}{l}\frac{\mathrm{a}}{3} \\
\frac{0}{\frac{\pi}{\pi}}\end{array}$ & 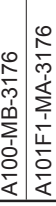 & 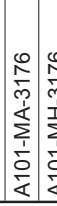 & 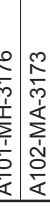 & & 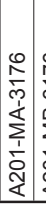 & & & & & & & & 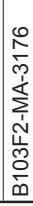 & & 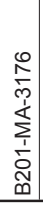 & & $\frac{4}{3}$ & & 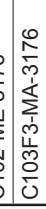 & 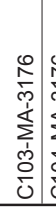 & & & & & $\sum_{\substack{j \\
d}}^{4}$ & & 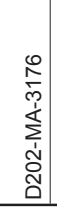 & 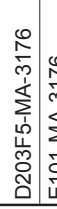 & & \\
\hline
\end{tabular}




\section{量}

产

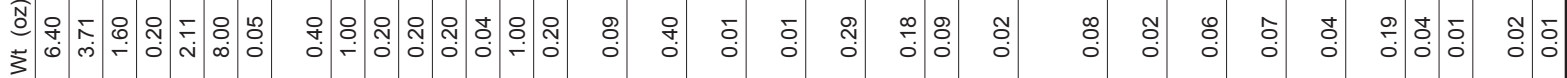

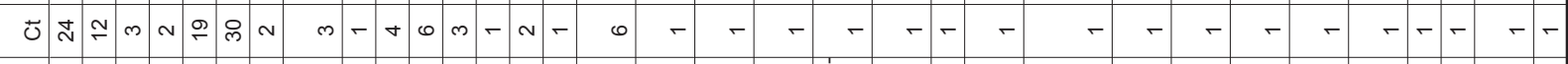

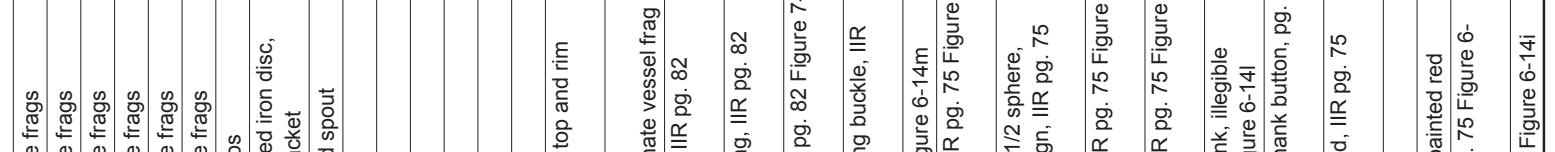

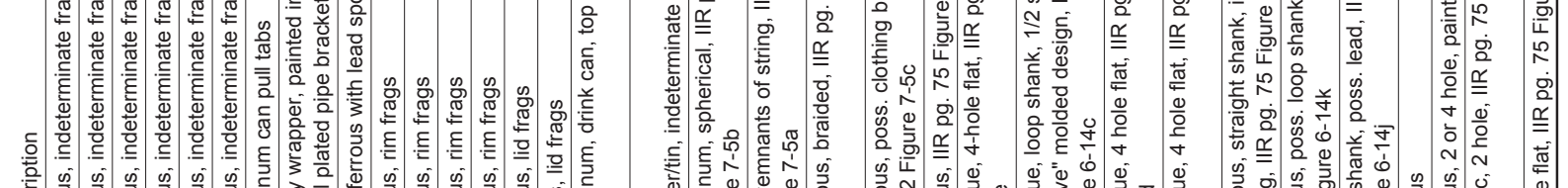

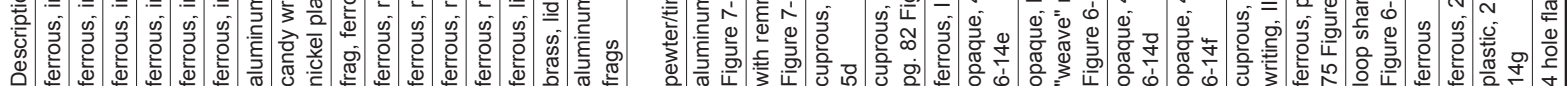

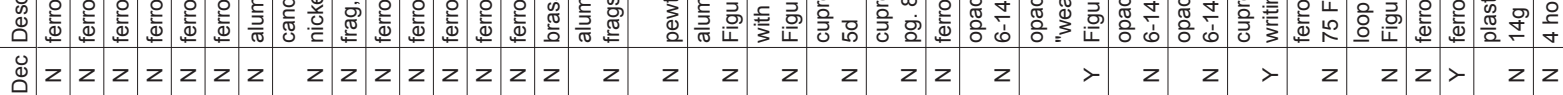

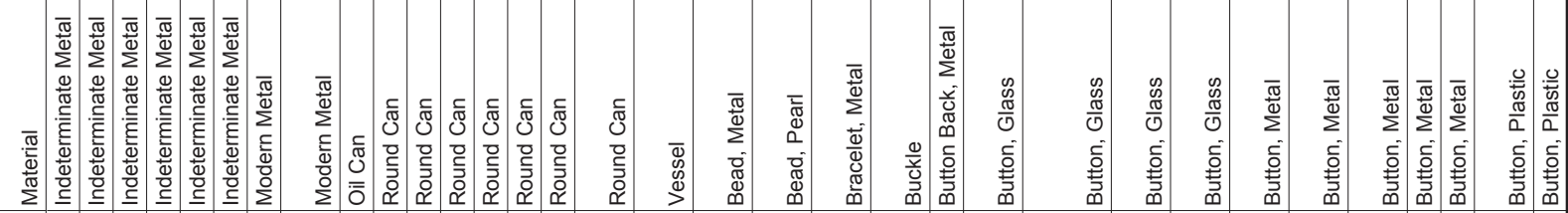

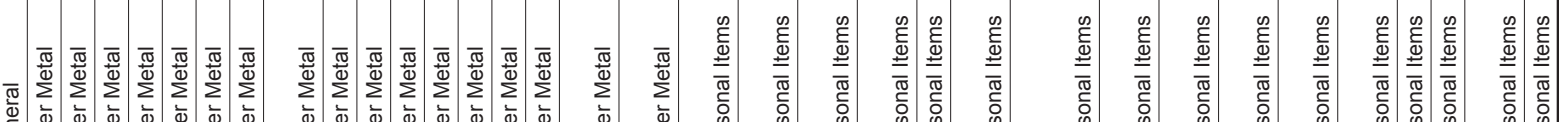

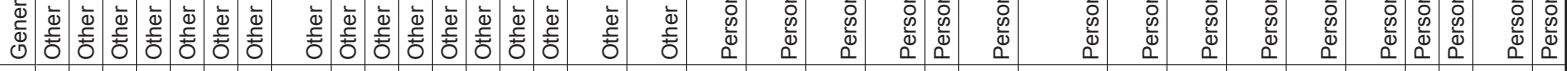
这家

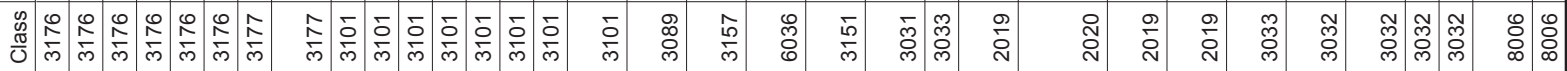

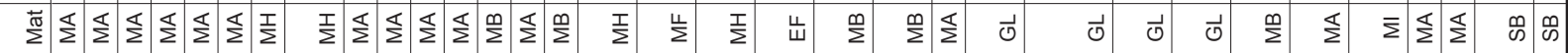

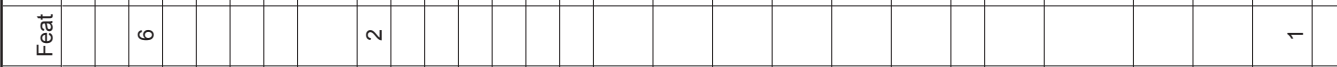

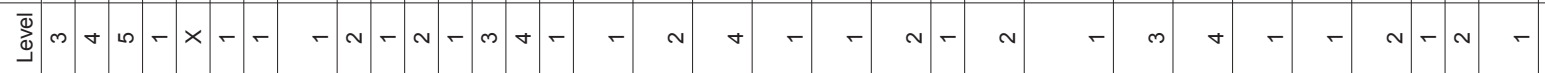

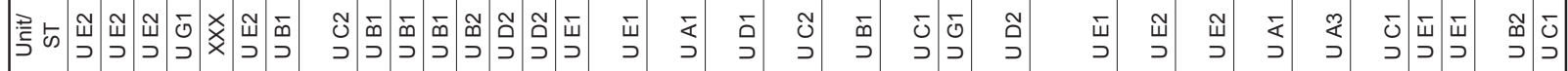

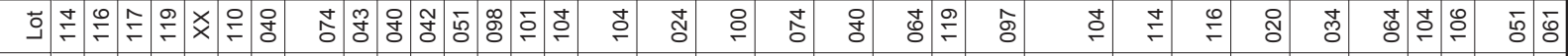

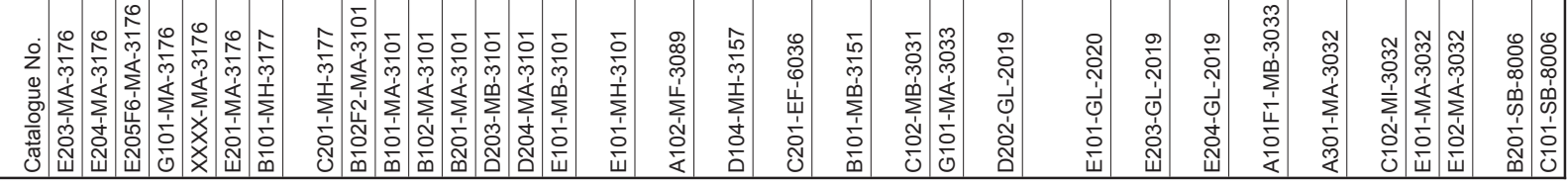




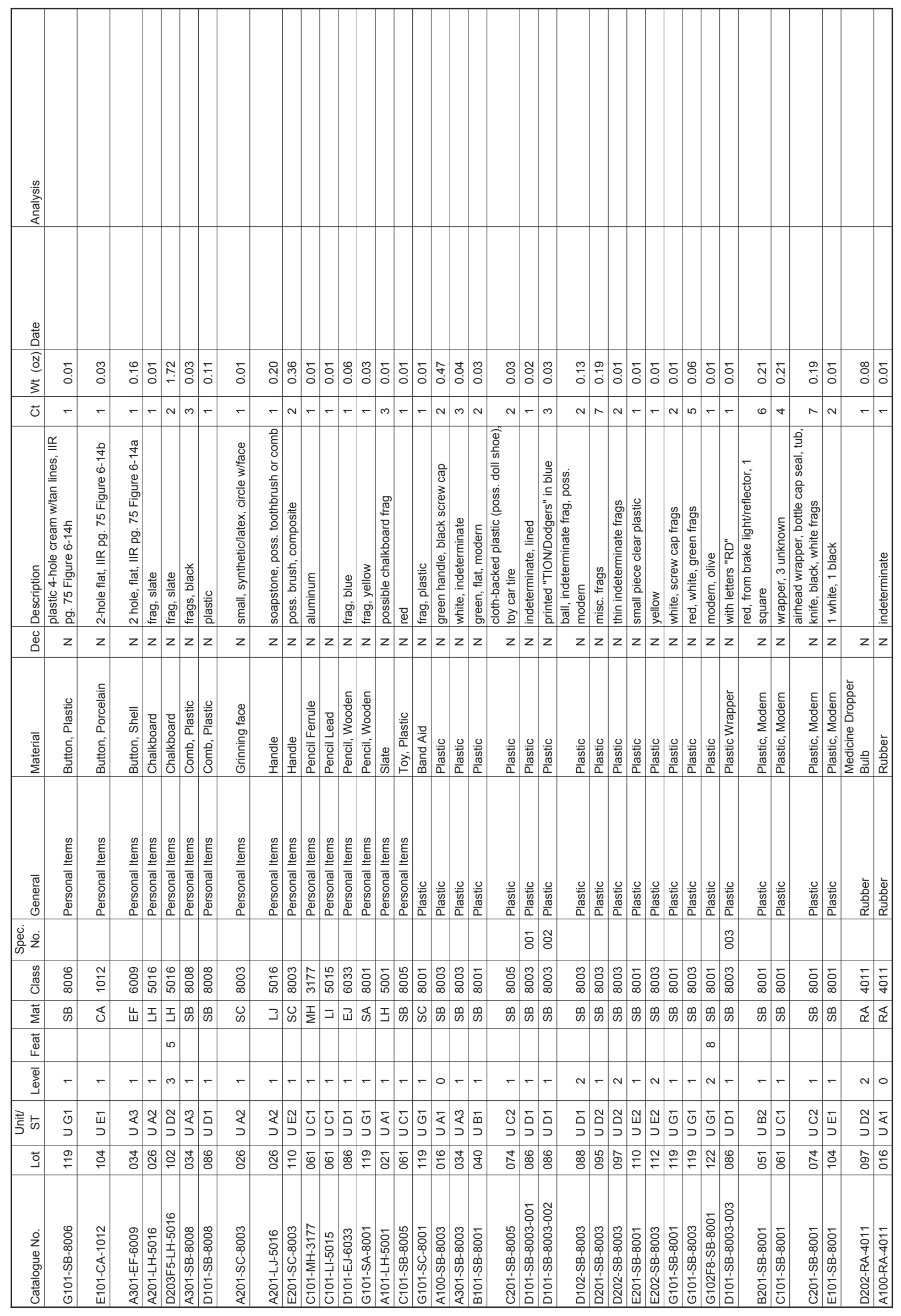




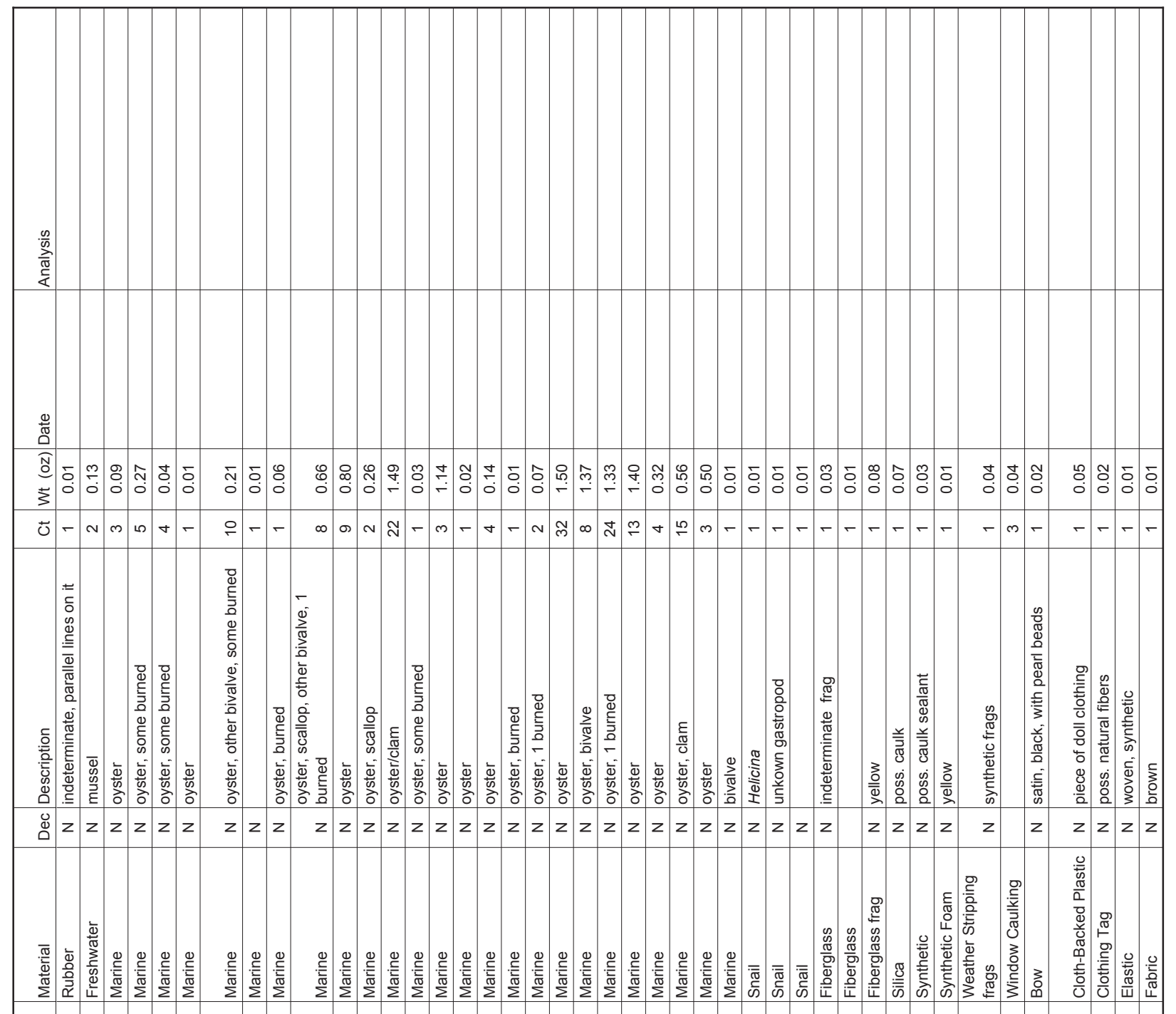

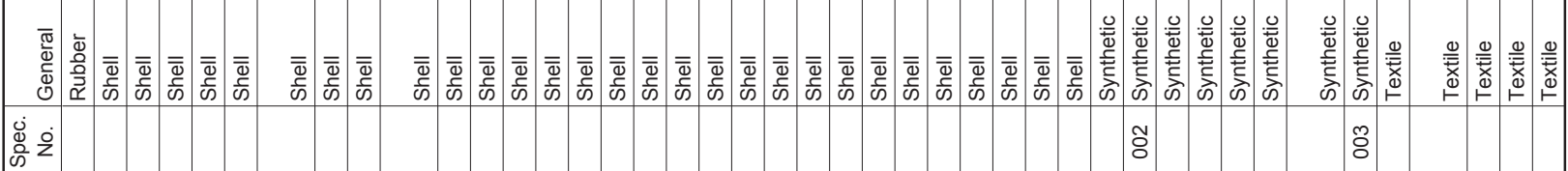

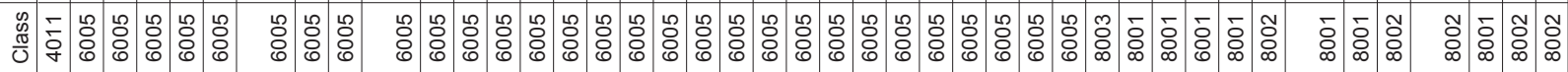

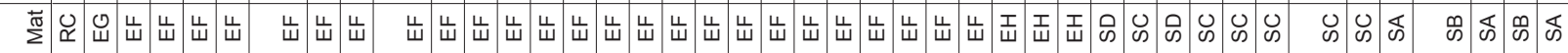

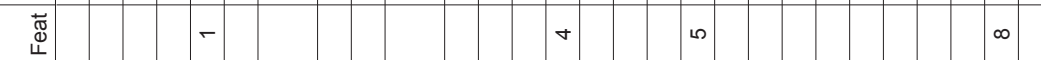

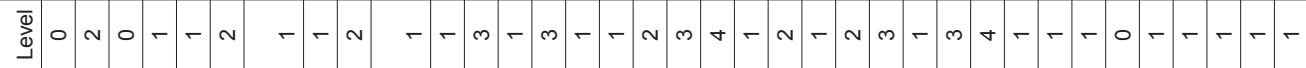

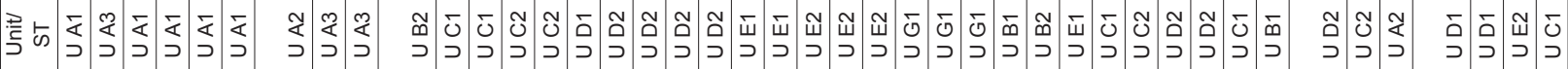

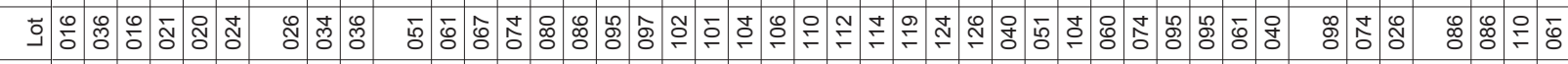

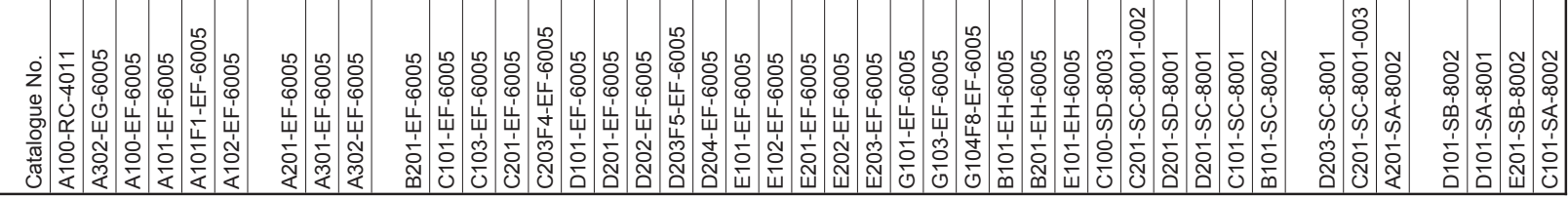




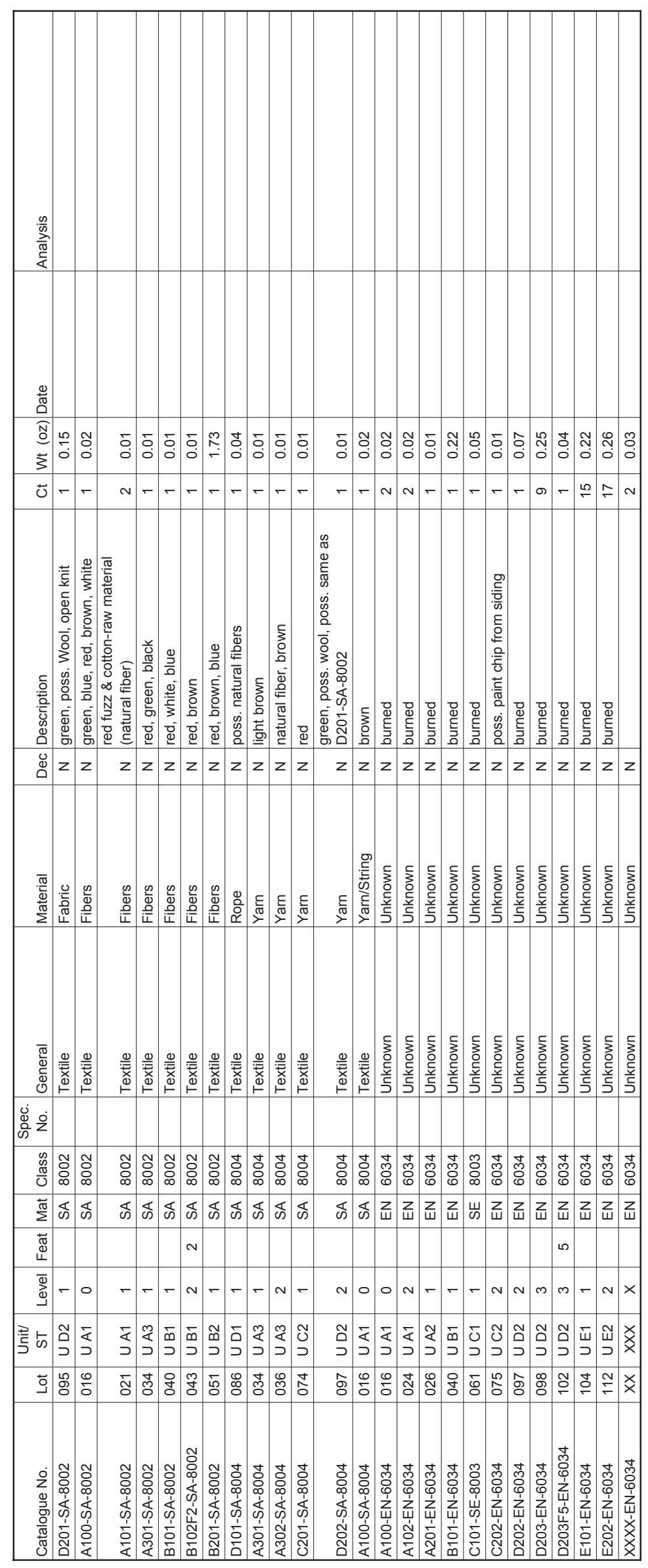

